\title{
Genesis and Residence Times of Soil and Weathering Profiles on Residual and Transported Parent Materials in the Pine Mountain Area of West-Central Georgia
}

\section{U.S. GEOLOGICAL SURVEY BULLETIN 1589-E}

Prepared in cooperation with the U.S. Department of Agriculture, Soil Conservation Service

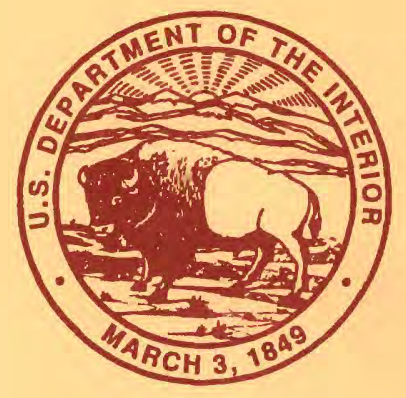




\section{SELECTED SERIES OF U.S. GEOLOGICAL SURVEY PUBLICATIONS}

\section{Periodicals}

monthly)

Earthquakes \& Volcanoes (issued bimonthly)

Preliminary Determination of Epicenters (issued

\section{Technical Books and Reports}

Professional Papers are mainly comprehensive scientific reports of wide and lasting interest and importance to professional scientists and engineers. Included are reports on the results of resource studies and of topographic, hydrologic, and geologic investigations. They also include collections of related papers addressing different aspects of a single scientific topic.

Bulletins contain significant data and interpretations that are of lasting scientific interest but are generally more limited in scope or geographic coverage than Professional Papers. They include the results of resource studies and of geologic and topographic investigations, as well as collections of short papers related to a specific topic.

Water-Supply Papers are comprehensive reports that present significant interpretive results of hydrologic investigations of wide interest to professional geologists, hydrologists, and engineers. The series covers investigations in all phases of hydrology, including hydrogeology, availability of water, quality of water, and use of water.

Circulars present administrative information or important scientific information of wide popular interest in a format designed for distribution at no cost to the public. Information is usually of short-term interest.

Water-Resources Investigations Reports are papers of an interpretive nature made available to the public outside the formal USGS publications series. Copies are reproduced on request unlike formal USGS publications, and they are also available for public inspection at depositories indicated in USGS catalogs.

Open-File Reports include unpublished manuscript reports, maps, and other material that are made available for public consultation at depositories. They are a nonpermanent form of publication that may be cited in other publications as sources of information.

\section{Maps}

Geologic Quadrangle Maps are multicolor geologic maps on topographic bases in 7.5- or 15-minute quadrangle formats (scales mainly $1: 24,000$ or $1: 62,500$ ) showing bedrock, surficial, or engineering geology. Maps generally include brief texts; some maps include structure and columnar sections only.

Geophysical Investigations Maps are on topographic or planimetric bases at various scales; they show results of surveys using geophysical techniques, such as gravity, magnetic, seismic, or radioactivity, which reflect subsurface structures that are of economic or geologic significance. Many maps include correlations with the geology.

Miscellaneous Investigations Series Maps are on planimetric or topographic bases of regular and irregular areas at various scales; they present a wide variety of format and subject matter. The series also includes 7.5-minute quadrangle photogeologic maps on planimetric bases that show geology as interpreted from aerial photographs. Series also includes maps of Mars and the Moon.
Coal Investigations Maps are geologic maps on topographic or planimetric bases at various scales showing bedrock or surficial geology, stratigraphy, and structural relations in certain coal-resource areas.

Oil and Gas Investigations Charts show stratigraphic information for certain oil and gas fields and other areas having petroleum potential.

Miscellaneous Field Studies Maps are multicolor or blackand-white maps on topographic or planimetric bases for quadrangle or irregular areas at various scales. Pre-1971 maps show bedrock geology in relation to specific mining or mineraldeposit problems; post-1971 maps are primarily black-and-white maps on various subjects such as environmental studies or wilderness mineral investigations.

Hydrologic Investigations Atlases are multicolored or black-and-white maps on topographic or planimetric bases presenting a wide range of geohydrologic data of both regular and irregular areas; principal scale is 1:24,000, and regional studies are at $1: 250,000$ scale or smaller.

\section{Catalogs}

Permanent catalogs, as well as some others, giving comprehensive listings of U.S. Geological Survey publications are available under the conditions indicated below from the U.S. Geological Survey, Information Services, Box 25286, Federal Center, Denver, CO 80225. (See latest Price and Availability List.)

"Publications of the Geological Survey, 1879-1961" may be purchased by mail and over the counter in paperback book form and as a set of microfiche.

"Publications of the Geological Survey, 1962-1970" may be purchased by mail and over the counter in paperback book form and as a set of microfiche.

"Publications of the U.S. Geological Survey, 1971-1981" may be purchased by mail and over the counter in paperback book form (two volumes, publications listing and index) and as a set of microfiche.

Supplements for 1982, 1983, 1984, 1985, 1986, and for subsequent years since the last permanent catalog may be purchased by mail and over the counter in paperback book form.

State catalogs, "List of U.S. Geological Survey Geologic and Water-Supply Reports and Maps For (State)," may be purchased by mail and over the counter in paperback booklet form only.

"Price and Availability List of U.S. Geological Survey Publications," issued annually, is available free of charge in paperback booklet form only.

Selected copies of a monthly catalog "New Publications of the U.S. Geological Survey" are available free of charge by mail or may be obtained over the counter in paperback booklet form only. Those wishing a free subscription to the monthly catalog "New Publications of the U.S. Geological Survey" should write to the U.S. Geological Survey, 582 National Center, Reston, VA 22092.

Note-Prices of Government publications listed in older catalogs, announcements, and publications may be incorrect. Therefore, the prices charged may differ from the prices in catalogs, announcements, and publications. 
Genesis and Residence Times of Soil and Weathering Profiles on Residual and Transported Parent Materials in the Pine Mountain Area of West-Central Georgia 


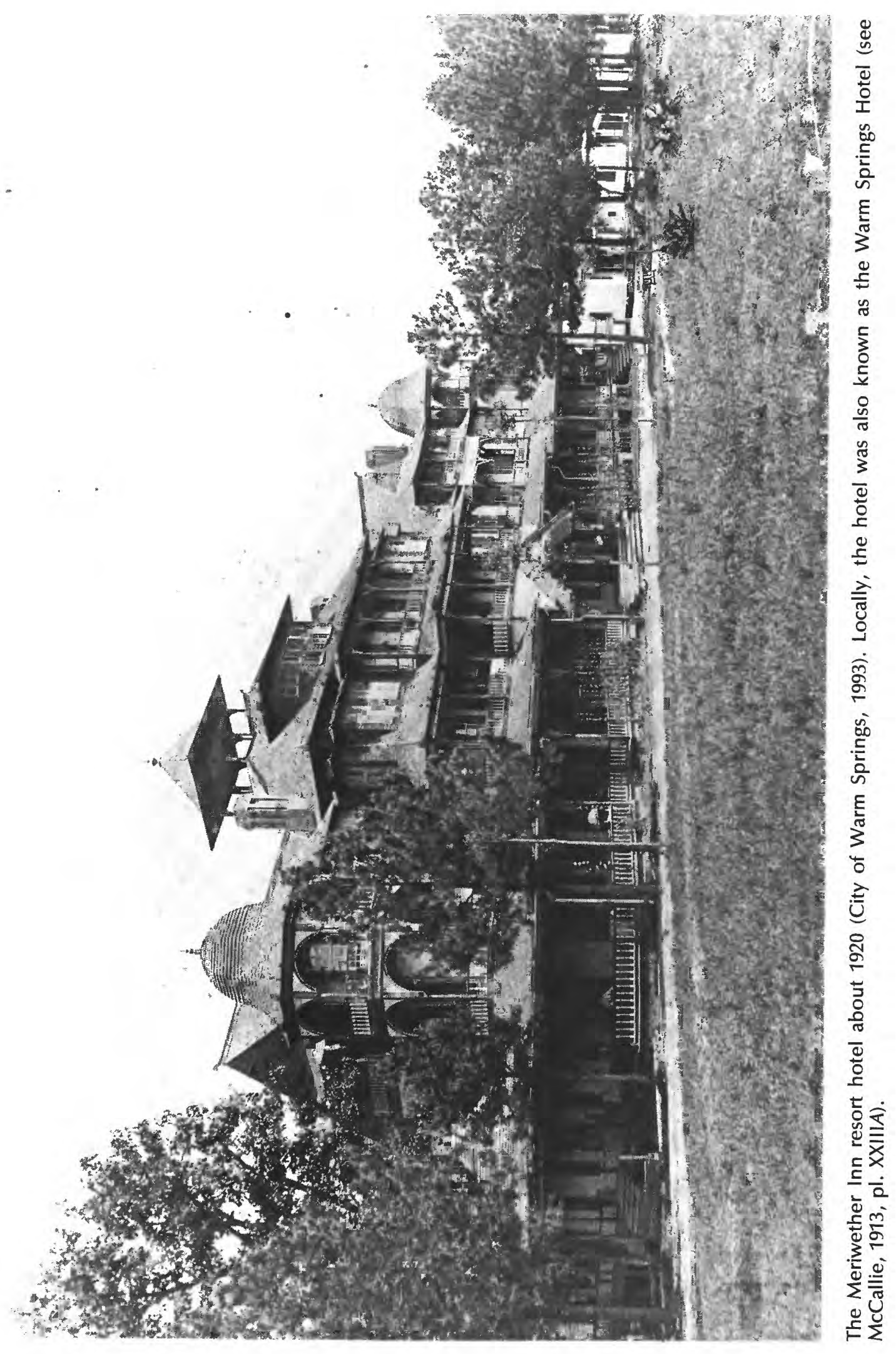




\title{
Chapter E
}

\section{Genesis and Residence Times of Soil and Weathering Profiles on Residual and Transported Parent Materials in the Pine Mountain Area of West-Central Georgia}

\author{
By H.W. MARKEWICH, M.J. PAVICH, W.C. LYNN, \\ G.J. THOMAS, R.C. JOHNSON, T.R. GERALD, and \\ G.G. PHILLIPS
}

Prepared in cooperation with the U.S. Department of Agriculture, Soil Conservation Service

Weathering and soil development in the Pine Mountain area of west-central Georgia largely reflect the texture, composition, and fabric of parent material. The pattern of ancient river terraces, alluvial fans, landslides, and colluvial aprons in a metasedimentary terrane has resulted in a mosaic of Pliocene to Pleistocene soils developed in residual and transported parent material. Soils common to the alluvial fans, debris flows, and other transported material are more similar to soils developed in unconsolidated Coastal Plain sediments than to those developed in the surrounding weathered Piedmont metasedimentary rocks

\section{U.S. GEOLOGICAL SURVEY BULLETIN 1589}




\title{
U.S. DEPARTMENT OF THE INTERIOR BRUCE BABBITT, Secretary
}

\author{
U.S. GEOLOGICAL SURVEY
}

Gordon P. Eaton, Director

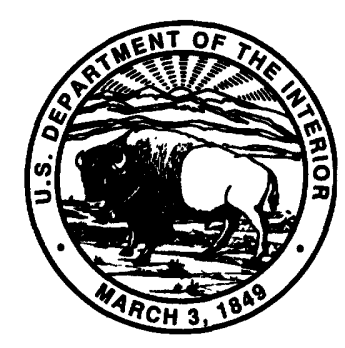

Any use of trade, product, or firm names in this publication is for descriptive purposes only and does not imply endorsement by the U.S. Government

For sale by

U.S. Geological Survey, Information Services

Box 25286, Federal Center, Denver, CO 80225

\section{Library of Congress Cataloging in Publication Data}

Genesis and residence times of soil and weathering profiles on residual and transported parent materials in the Pine Mountain area of west-central Georgia / by H.W. Markewich ... [et al.].

p. $\quad$ Cm. - (U.S. Geological Survey bulletin ; 1589-E) (Pedologic studies in the eastern United States, relations to geology ; ch. E)

"Prepared in cooperation with the Department of Agriculture, Soil Conservation Service."

Includes bibliographical references.

Supt. of Docs. no.: | 19.3:1589-E

1. Soils-Georgia-Pine Mountain Region-Age. 2. Soil formation-Georgia-Pine Mountain Region. 3. Weathering-Georgia-Pine Mountain Region. 4. Geology-Georgia-Pine Mountain Region. I. Markewich, Helaine W. II. United States. Soil Conservation Service. III. Series. IV. Series: Pedologic studies in the eastern United States, relations to geology ; ch. E.

QE75.B9 no. 1589-E

[S599.G4] 


\section{Preface}

Some geologic investigations of Quaternary deposits, especially in the conterminous United States, have attempted to use relative degrees of weathering and soil formation to establish chronosequences of glacial and (or) fluvial landforms. Most studies have been in the glacial terrane of the midcontinent and the Western United States. Few such studies have been conducted in the Eastern United States, especially in the unglaciated Middle Atlantic and Southeastern States.

From 1980 to 1984, the U.S. Geological Survey and the U.S. Department of Agriculture's Soil Conservation Service conducted cooperative regional studies of the relations between soils and geology in the Middle Atlantic and Southeastern States. The primary goal of the studies was to determine if soil properties could be used to estimate ages of associated landforms. Coral, wood fragments, and peat were sampled from constructional landforms of fluvial and marine origin in order to estimate ages by isotopic analyses; these ages were then related to regional biostratigraphic and lithostratigraphic correlations. Specific site investigations were conducted on Pliocene to Holocene marine and fluvial terraces in the Atlantic and eastern Gulf Coastal Plains and the Appalachian Piedmont. In addition to transported materials, soils on granite, schist, and quartzite of the Appalachian Piedmont were also sampled to test the use of soil properties as indicators of soil age. Each chapter of this bulletin series examines the relation of soils to geology in a specific geographic area.

The cooperative study involved research scientists from both agencies and field personnel from State offices of the Soil Conservation Service. Responsibility for sample analysis was divided between the Department of Agriculture's National Soil Survey Laboratory in Lincoln, Nebr., and the U.S. Geological Survey in Reston, Va. This report was prepared by scientists from both agencies who participated in specific site investigations or in studies of pedogenic processes. 


\section{CONTENTS}

Preface V

Abstract E1

Introduction E1

Purpose and Scope E2

Land Use E2

History of the U.S. Geological Survey's Interest in the Area around Warm

Springs, Georgia E2

Acknowledgments E2

Field and Laboratory Methods $\mathbf{E 3}$

Environmental Setting E3

Climate E3

Paleoclimate E7

Vegetation $\mathbf{E 7}$

Geologic and Geohydrologic Settings E8

Geology E9

Geohydrology E10

Warm Springs E10

Cold Spring E11

Parent Material and Associated Soil and Weathering Profiles E11

Residual Soils in Piedmont Parent Material E12

Mountain Parent Material and Soils E14

Pedon 231-001: Quartzite Residual Soil E16

Pedon 231-003: Colluvium over Quartzite E19

Pedon 231-004: Quartzite Residual Soil E27

Pedon 231-002: Landslide Debris (Quartzite) E27

Soil and Weathering Profiles in Alluvial Fan Parent Material E29

Soil and Weathering Profiles in Terrace Alluvium E35

Landslides and Associated Weathering Profiles E36

Debris Flows E36

Discussion $\mathbf{E 3 7}$

Weathering and Relative Residence Times of Weathering Profiles E37

Pedogenesis E39

Argillic Horizons E39

Desilication of Argillic Horizons $\mathbf{E 4 0}$

Fragic Horizons E40

Age Estimates for Soils and Geomorphic Surfaces E41

Summary $\mathbf{E 4 3}$

References Cited $\mathbf{E 4 3}$

Tables 6-14 E47

Appendix $\mathbf{E 6 3}$ 


\section{FIGURES}

1. Maps showing major geologic and geographic features of the Pine Mountain area of Alabama and Georgia, locations of major springs, and all soil and weathering profile sample sites E4, E5

2. Graphs showing least-squares sinusoidal fit of long-term periodic temperatures for Flint River near Griffin, Ga., Potato Creek near Thomaston, Ga., and Mountain Oak Creek near Hamilton, Ga. E6

3, 4. Maps showing:

3. Mean annual precipitation and estimated mean annual lake evaporation for Georgia $\mathbf{E 7}$

4. Relief map of the Piedmont and Blue Ridge physiographic provinces E9

5. Ternary diagrams showing compositions of cold- and warm-water springs in the Pine Mountain area of Georgia E12

6. Maps showing soil and weathering profile sample sites in parts of the Sunset Village, Thomaston, Zebulon, Warm Springs, Woodbury, and Durand 7.5-min quadrangles E14-E19

7. Summary plots of data for pedons S84GA-199-001, S84GA-231-001, S84GA-231-003, S84GA-231-004, S84GA-231-002, S84GA-293-001, and S84GA-199-002 and an unnumbered pedon in Flint River terrace alluvium E20-E27

8. Diagrams showing X-ray diffraction patterns for pedons S84GA-199-001, S84GA-231-001, S84GA-293-001, and S84GA-199-002, an unnumbered pedon in Flint River terrace alluvium, and three unnumbered weathering profiles E28-E30

9. Photomicrographs of C2 horizon of pedon S84GA-199-001 E31

10. Stereo aerial photographs showing landscape position of alluvial fans and landslides in the Sunset Village and Warm Springs 7.5-min quadrangles E32,E33

11. Map and photograph of an east-facing alluvial fan deposit exposed in a railroad cut near Parkman Pond in the Shiloh 7.5-min quadrangle of Georgia E34

12. Cross section of the eastern half of a roadcut through a fining-upward sequence of terrace alluvium adjacent to White Sulphur Creek showing its position as channel fill cut into metamorphic rocks that are now saprolitized E35

13. Photograph showing small-boulder-sized clasts in a landslide deposit exposed along Jeff Davis Road on the southern side of Bull Trail Mountain E36

14. Map showing topographic expression of SSE.-facing debris flows in the Pine Mountain SW 7.5-min quadrangle of Georgia E37

15. Photographs of site 12 showing details of SSE.-facing debris flows $\mathbf{E 3 8}$ 16-19. Plots showing:

16. Percentage of fine silt versus the percentage of clay for all horizons of all sampled pedons $\mathbf{E 4 0}$

17. Ratio of fine silt to coarse silt versus the percentage of clay for argillic and fragic horizons from selected pedons $\mathbf{E 4 1}$

18. Relation of $\left(\mathrm{Fe}_{2} \mathrm{O}_{3}+\mathrm{Al}_{2} \mathrm{O}_{3}\right) / \mathrm{SiO}_{2}$ to clay mass and of solum $\left(\mathrm{Fe}_{2} \mathrm{O}_{3}+\mathrm{Al}_{2} \mathrm{O}_{3}\right) / \mathrm{SiO}_{2}$ to ages of depositional units $\mathbf{E 4 2}$

19. Comparison of thickness of argillic and fragic horizons to depths of oxidation for fan, mountain, and Piedmont soils E42 
TABLES

1. Analyses of primary and sedimentary kaolin and bauxite from the area around Warm Springs, Meriwether County, Georgia E11

2. Discharge and temperature data from several springs in the area of Pine Mountain, Georgia E11

3. Analytical data from a cold spring at the National Fish Hatchery at Warm Springs, Georgia E12

4. Soil sampling site locations and geomorphology E13

5. Analyses, methods, and units of expression for analyses conducted at the National Soil Survey Laboratory $\mathbf{E 1 3}$

6-12. Field descriptions and analytical data for:

6. Pedon S84GA-199-001 E48

7. Pedon S84GA-231-001 E50

8. Pedon S84GA-231-003 E52

9. Pedon S84GA-231-004 E54

10. Pedon S84GA-231-002 E55

11. Pedon S84GA-293-001 E57

12. Pedon S84GA-199-002 E58

13A, B. Textural analyses and other analytical data for unnumbered soil developed in Flint River terrace alluvium E60

14. Sand mineralogy of Pine Mountain soils E61 


\title{
Genesis and Residence Times of Soil and Weathering Profiles on Residual and Transported Parent Material in the Pine Mountain Area of West-Central Georgia
}

\author{
By H.W. Markewich, ${ }^{1}$ M.J. Pavich, ${ }^{2}$ W.C. Lynn, ${ }^{3}$ G.J. Thomas, ${ }^{4}$ R.C. Johnson, ${ }^{5}$ T.R. Gerald, ${ }^{6}$ \\ and G.G. Phillips ${ }^{7}$
}

\begin{abstract}
The 100-mi-long, 1.2- to 6.2-mi-wide Pine Mountain area of Alabama and Georgia is a physiographically and geologically unique part of the southern Appalachian Piedmont physiographic province. The high, narrow ridges, incised streams, and numerous surficial deposits combine to form a landscape more similar to the Valley and Ridge and Blue Ridge physiographic provinces than to the rolling topography of the surrounding Piedmont province. The soil and weathering profiles developed in this area largely reflect the effect that parent material has had on the stability of the land surface. The oldest soils and deepest weathering profiles are associated with the least eroded positions on constructional landforms such as alluvial fans, landslides, debris flows, and alluvial terraces. Matrix and clast composition of these transported parent materials is primarily Hollis Quartzite. Soils developed in erosional remnants of these deposits are no younger than early Pleistocene. We estimate their ages
\end{abstract}

Manuscript approved for publication September 7, 1994.

${ }^{1}$ U.S. Geological Survey, Atlanta, GA 30360.

${ }^{2}$ U.S. Geological Survey, Reston, VA 22092.

${ }^{3}$ U.S. Department of Agriculture, Soil Conservation Service, National Soil Survey Laboratory, Lincoln, NE 68508.

${ }^{4}$ U.S. Department of Agriculture, Soil Conservation Service, Decatur, GA 30030. (Present address: Thomas Soil Consulting Service, P.O. Box 517, Epworth, GA 30541.)

${ }^{5}$ U.S. Geological Survey, Reston, VA 22092. (Present address: 12210 Sugar Maple Drive, Herndon, VA 22070.)

${ }^{6}$ U.S. Department of Agriculture, Soil Conservation Service, Athens, GA 30601.

${ }^{7}$ U.S. Geological Survey, Reston, VA 22092. (Now at U.S. Environmental Protection Agency, Denver, CO 80202.) between late Miocene and late Pliocene (from 6 to 2 million years).

Although soils of all ages are present on the high narrow ridges that characterize the Pine Mountain area, data suggest that residual soils developed in the least eroded positions on the ridges are younger than the soils developed on most surficial deposits. We estimate the mountain soils to be early to middle Pleistocene in age. The youngest soils in the area are those developed in granite, granitic schist, and gneiss of the surrounding Piedmont. We estimate these soils to be younger than 1 Ma.

It is the composition, fabric, and internal structure of the parent material that have the greatest effects on the style and degree of weathering and on the rate(s) of erosion. Differences in soil ages mirror differences in erosion rates.

\section{INTRODUCTION}

This study was a cooperative effort between the U.S. Geological Survey (USGS) and the U.S. Department of Agriculture's Soil Conservation Service (SCS) to describe, classify, analyze, compare, and determine the ages of soil and weathering profiles developed in different parent materials in the Pine Mountain area of west-central Georgia. These soil and weathering profiles have developed in residuum and transported parent materials in a low-latitude, wet to humid, temperate to subtropical, high-relief terrain. Parent materials include granite and granitic gneiss on the Piedmont lowland, a porous, flexible lithotype (itacolamite) of the Hollis Quartzite underlying the high ridges, and transported material comprising alluvial fans, alluvial terraces, and landslides. We compared the properties of the 
soil and weathering profiles in order to establish a relative chronosequence of profile development. Estimates of absolute age were made by comparing the weathering and soil profile data with data from soil and weathering profiles of known ages from Virginia, North Carolina, South Carolina, Georgia, and Alabama. This study and others in the region are part of a long-term effort to (1) identify and understand the processes involved in weathering and soil development in the temperate to subtropical areas of the United States and (2) use soil and weathering profile data to estimate ages of erosional surfaces and constructional landforms to better understand the evolutionary history of a region's landscape.

\section{Purpose and Scope}

The Pine Mountain area of Alabama and Georgia includes the southernmost mountains of the Eastern United States (figs. $1 A, B$ ). It is a high-relief area of ENE.trending ridges and valleys surrounded by relatively low relief Piedmont terrain. The area is known for its numerous springs and its unusual faunal and floral assemblages. We restricted our study to that part of the Pine Mountain area in Georgia between the communities of Hamilton and Thomaston. The study area includes the area of Cenozoic faulting around Warm Springs (figs. $1 A, B$ ).

The primary goal of the study was to use lithologic, geomorphic, weathering, and pedogenic data to better understand the physiographic evolution of the Pine Mountain area in west-central Georgia. Specific objectives included:

1. Identification of the different types of surficial deposits that characterize the area.

2. Characterization and comparison of soils developed on quartzite-rich alluvial fans, on the narrow quartzitecored mountainous ridges, on large landslide blocks of quartzite, and on the surrounding rolling hills underlain by granite and granitic schist and gneiss.

3. Determination of minimum ages for the area's constructional landforms by comparing their soil and weathering profile characteristics with those from chronosequences in Virginia, North Carolina, South Carolina, Georgia, and Alabama.

\section{Land Use}

Settlement of the Piedmont of west-central Georgia began shortly after the Treaty of Indian Springs in 1825 . Agriculture, specifically cotton production, was the dominant land use before the early 1930's. Textile manufacturing accompanied cotton production. With textiles came the railroads. In the late 1800 's and early 1900 's, five different rail lines were in use in the Pine Mountain area. Boll weevil infestations in the 1920's, the development of synthetic fabrics, and the nationwide economic depression of the 1930 's contributed to a regional decline in agriculture and a subsequent decline in textile production and the railroads. Since that time, the area has been intermittently exploited for its value in tourism, medical rehabilitation, mining, fish farming, peach and apple production, poultry production, horse and cattle breeding, and timber production. Each of these activities has met with limited success. The rehabilitation facility at Warm Springs and the nearby National Fish Hatchery have contributed to the local economy continuously (but at fluctuating levels) since the late 1920 's. Textile manufacturing has continued on a greatly reduced scale. As a result, this easily accessible and beautiful part of Georgia has remained predominantly rural, boasting few communities greater than 10,000 in population.

\section{History of the U.S. Geological Survey's Interest in the Area around Warm Springs, Georgia}

In the 1930's and 1940's, President Franklin Delano Roosevelt maintained a residence in Warm Springs, Ga., near the polio rehabilitation facility that utilized the $88^{\circ} \mathrm{F}$ high-volume springs of the same name. As a result of President Roosevelt's interest in Warm Springs, the USGS mapped the Warm Springs 15-min quadrangle and conducted studies on the source and hydrogeological properties of the springs (see appendix). This study was published as USGS Water Supply Paper 819 (Hewett and Crickmay, 1937), which is no longer in print.

In the middle 1940's, as a result of wartime interest in strategic minerals, the USGS again investigated the geology of the Pine Mountain area. Interest centered on the origin and potential of a small bauxite deposit in downfaulted kaolinitic sediments on the northern side of Pine Mountain, a few miles west of the town of Warm Springs (White, 1965). In the late 1970's and early 1980's, interest in the bauxite deposits near Warm Springs was renewed. Pollen from fluvial sediments associated with the bauxite beds was identified as late Paleocene and early Eocene (Sabinian) in age and thereby verified post-Sabinian faulting (Christopher and others, 1980; Reinhardt and others, 1984a, b; Prowell, 1987).

\section{Acknowledgments}

The study presented here was the result of a cooperative project between the USGS and the SCS, from 1984 to 1988 , to study the relations between parent material and soils and to establish a relative chronology of constructional and erosional landforms in the area.

We thank David C. Prowell (USGS) for first acquainting us with some of the surficial deposits and near-surface deformation features in the area around Thomaston, Ga., and for numerous discussions both in the field and at the office. We thank Michael W. Higgins, 
E. Joseph Inman, and Jamie B. Shanley (USGS), who allowed us to use their unpublished data. Higgins provided us with his bedrock mapping of the area. Inman and Shanley allowed us to use precipitation data from the western Georgia Piedmont. Special thanks go to Jesse M. Gunn and Hoyt Dunn of Meansville, Ga., and Hiram W. Kersey of Thomaston, who allowed us unconditional access to their properties.

We would like to express our appreciation to J.P. Owens, R.B. Mixon, and J.T. Hack (USGS) and R.A. Daniels and Klaus Flach (SCS) for suggesting a cooperative project between the two agencies.

Steven F. Obermeier and Jennifer Harden (USGS) and Robert L. Wilkes (SCS) contributed thoughtful reviews of the manuscript. Carolyn D. Becker and Julie Reynolds (USGS) prepared the manuscript.

We especially thank Kathie R. Fraser (USGS) for her editorial assistance, not only with this manuscript but with many of the chapters in this series as well.

\section{FIELD AND LABORATORY METHODS}

The seven study pedons were described and sampled by the authors and local personnel from the SCS. All pedons were sampled in backhoe trenches. Weathering profiles were described and sampled for clay mineralogy from roadcuts and quarries. Pedon numbers are standard SCS notation, which gives the year, the State abbreviation, the county number, and the pedon number in the county (for example, S81AL-087-001). Pedons discussed in this report are referred to by the last six digits of their complete pedon numbers. Horizon designations follow the revision of the Soil Survey Manual (Soil Survey Staff, unpub. manual, 1981) and also a brochure produced by Cornell University and the U.S. Department of Agriculture's Agency for International Development (Soil Survey Staff, 1986). New horizon designations are used in the text of this report

Samples were sent to the SCS National Soil Survey Laboratory (NSSL) in Lincoln, Nebr., where they were split; one set was then sent to the USGS laboratories in Reston, Va., and the other was retained by the NSSL. Samples were analyzed for standard physical and chemical characteristics at the NSSL. Some of the analyses conducted at the NSSL are particle-size distribution, cation exchange capacity, $\mathrm{pH}$, base saturation, and $\mathrm{X}$-ray diffraction on the $<2-\mu \mathrm{m}$ fraction of selected horizons (magnesium saturated at room temperature, magnesium saturated and glycerol solvated at room temperature, potassium saturated at 300 and $500{ }^{\circ} \mathrm{C}$ ). Diffraction patterns presented in this report represent glass-mounted slides of clay that were magnesium saturated at room temperature. The USGS laboratories conducted additional analyses, including bulk chemistry by X-ray fluorescence and analyses of iron and aluminum by oxalate extraction and by atomic absorption.

\section{ENVIRONMENTAL SETTING}

\section{Climate}

The climate of the Pine Mountain area of westcentral Georgia is considered to be wet to humid and temperate to subtropical. The average temperature is no higher than $80^{\circ} \mathrm{F}$ in any one month. The average minimum monthly temperature in the summer is about $68^{\circ} \mathrm{F}$. Hewett and Crickmay (1937, p. 4) reported temperature data from West Point, Warm Springs, and Talbotton (locations on fig. $1 A$ ):

According to the records of the United States Weather Bureau, the average air temperature at West Point, 28 miles west of Warm Springs, is $63.3^{\circ} \mathrm{F}$, and at Talbotton,

17 miles southeast, $64.1^{\circ} \mathrm{F}$.

Variations in surface water temperatures also reflect the variability of the air temperature. Dyar and Stokes (1973) show $35^{\circ} \mathrm{F}$ seasonal change in temperature for the Flint River and its tributaries in the Pine Mountain area (see figs. $2 A, B, C$ ).

Prevailing winds in the west-central Piedmont are from a northerly direction in the winter and a southerly direction in the summer. Local wind speeds can vary from averages of $10 \mathrm{mph}$ in the spring to $7 \mathrm{mph}$ in the late summer. The influence of cold winds from the north and northwest and of warm southern winds from the Gulf of Mexico can, in the winter, produce frequent and large temperature variations over relatively short periods of time. The cold spells, which drop morning temperatures below freezing, are usually shorter than the alternating periods of milder weather. Temperature usually rises above freezing even on the coldest winter days, which can, on rare occasions, see morning temperatures near zero. Every few years, there is a measurable amount of snow. Average rainfall is about 49 to 52 in per annum (fig. 3). Frequent thunderstorms occur in the spring and summer, occasionally accompanied by damage-causing winds and hail (Wells, 1965).

Hewett and Crickmay (1937, p. 72) reported that rainfall at six stations within $35 \mathrm{mi}$ of Warm Springs ranged between 46 and 58 in a year in 1934. These data not only show local variability in rainfall in the Pine Mountain area but also indicate that the local range of annual precipitation (12 in) is well within the 20 -in range of precipitation for any 10 -yr period.

Rainfall is seasonal; evapotranspiration is greater than precipitation for a minimum of 3 months a year. Kohler and others (1959) showed mean annual lake evaporation between 42 and 44 in for this area of Georgia. Periods of intense rainfall are not unusual. As a result of Hurricane Agnes on June 21, 1972, the Pine Mountain area of Alabama and Georgia received up to 4 in of rain in one 24-hr period; 1 to 2 more inches fell in the following 24-hr period (Bailey and others, 1975). As the result of a recent 


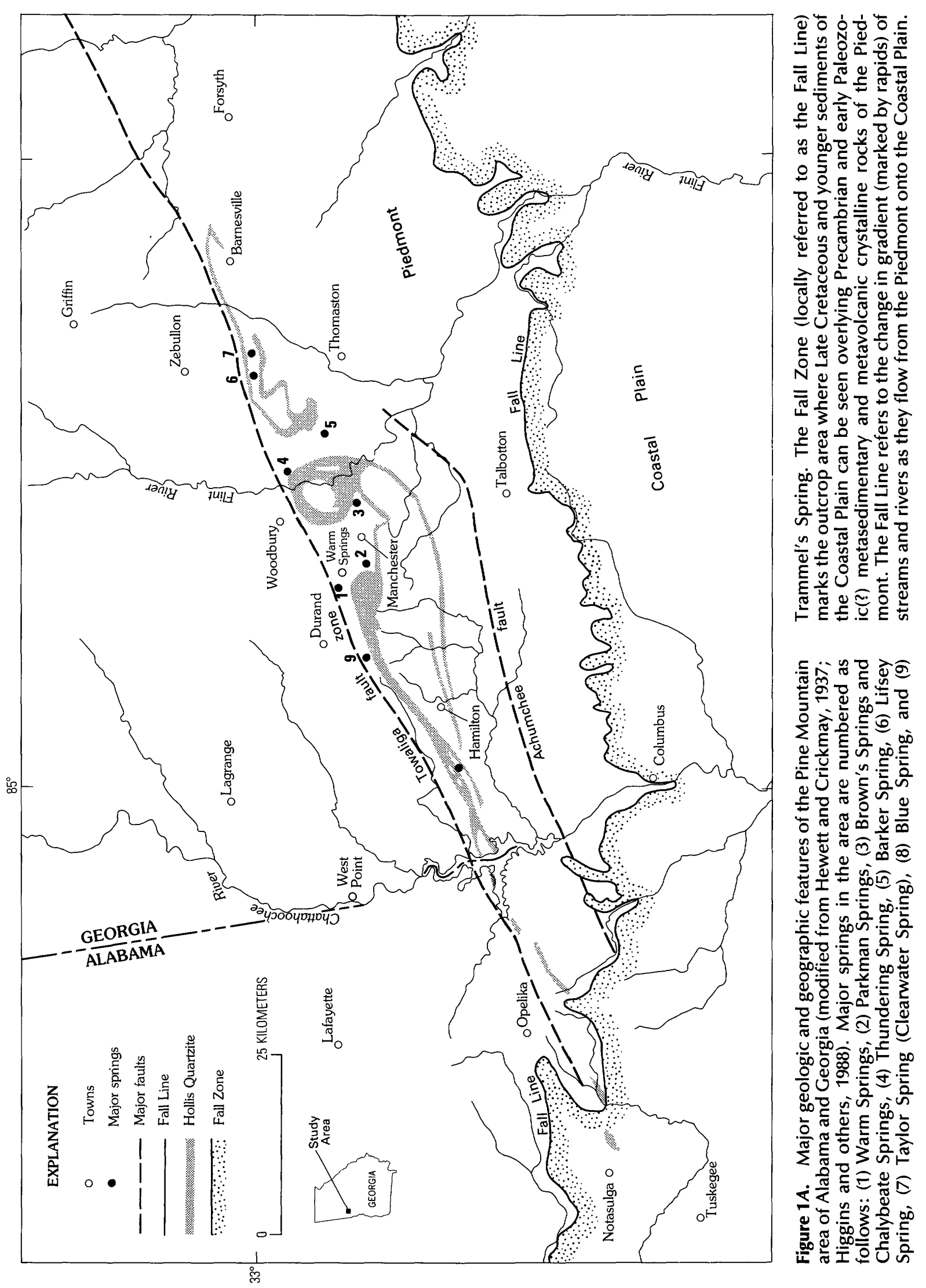




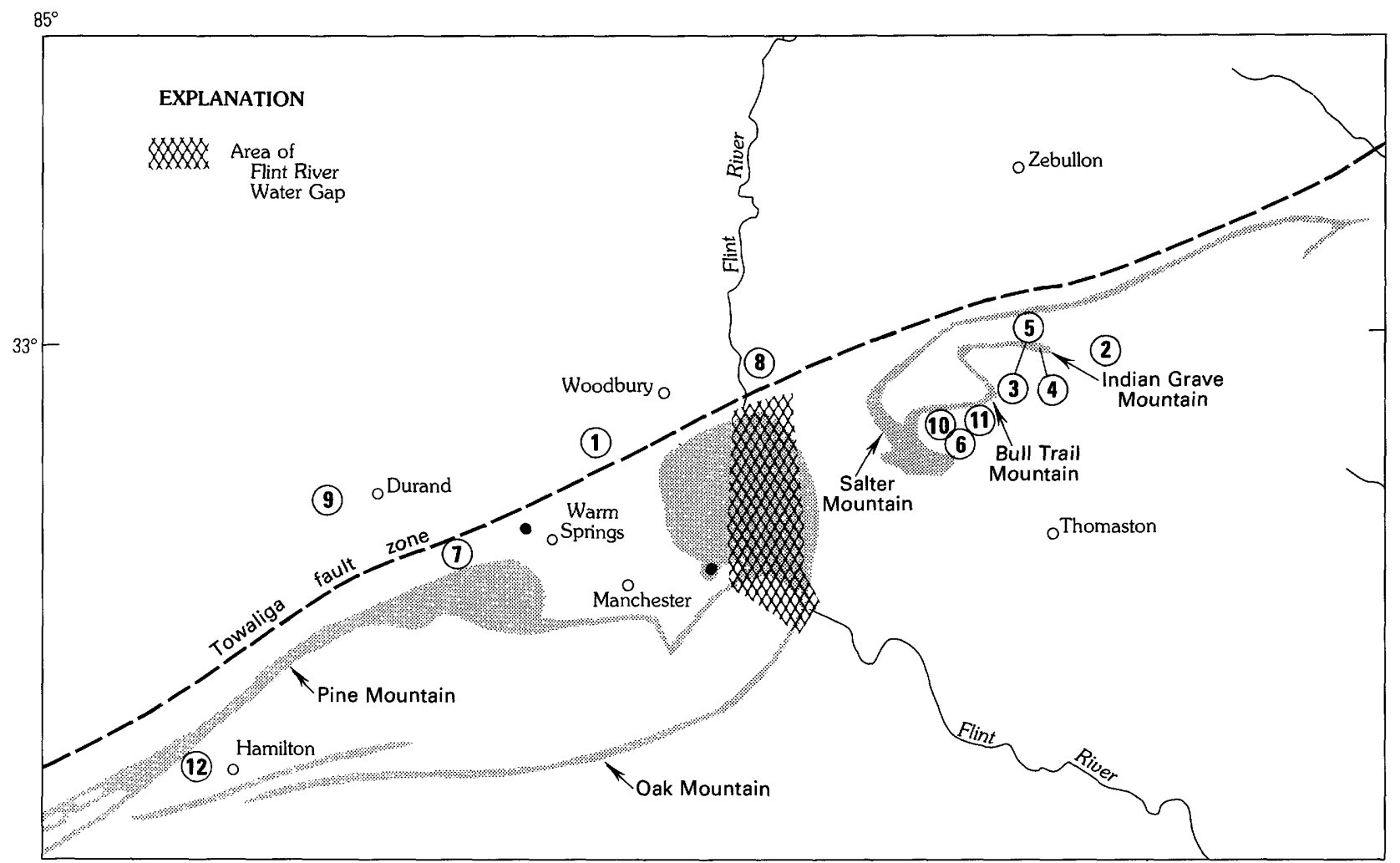

Figure $1 B$. Location of the study area. Soil and weathering profile sample sites are numbered as follows: (1) S84GA-199-001 (Piedmont soil), (2) S84GA-231-001 (mountain soil), (3) S84GA-231-003 (mountain soil), (4) S84GA-231-004 (mountain soil), (5) S84GA-231-002 (landslide/mountain soil), (6) S84GA-293-001 (fan soil), (7) S84GA-199-002 (fan soil), (8) unnumbered soil profile (Flint River terrace alluvium), (9) weathering profile (White Sulphur Creek terrace alluvium), $(10,11)$ weathering profile (old landslide deposit on southern side of Bull Trail Mountain), and (12) reticulate mottling in clasts and matrix (roadcut through debris slides about 2 mi NNW. of Hamilton, Ga.). tropical storm, the weather station at Woodbury reported 7.15 in of rain during the 24 -h period from 7 a.m. July 4 to 7 a.m. July 5, 1994. Butler, Ga., located 9 mi south of Talbotton, reported 12.15 in during the same 24 -h period (National Oceanic and Atmospheric Administration, provisional unpub. data, 1994).

Local storms can be very intense. Hourly data for Hamilton, Ga., show 1.7 in of precipitation from 12 noon to 1 p.m. on April 4, 1974 (National Oceanic and Atmospheric Administration, 1974). Data for West Point, Ga. (25 mi northwest of Hamilton) (see fig. $1 A$ ), show precipitation of 1.00 in from 5 to 6 p.m. on May 28, 1986, 1.30 in from 6 to 7 p.m. on June 9, 1986, and 1.50 in from 6 to 7 p.m. on July 17,1986 . In the same year, Hamilton's maximum was recorded as 1.00 in from 7 to $8 \mathrm{a} . \mathrm{m}$. on March 19, (National Oceanic and Atmospheric Administration, 1986). Unpublished data from other localities in the Piedmont show that the periods of high rainfall recorded hourly are commonly short periods (15-20 min) of intense rainfall that start suddenly and then taper gradually. ${ }^{8}$

\footnotetext{
${ }^{8}$ One data set from a small drainage basin $\left(2.19 \mathrm{mi}^{2}\right)$ in northeastern Atlanta, Ga., provides a record for four storm events. On August 14, 1973, 1.104 in of rain fell in $15 \mathrm{~min}$. On this date, precipitation records made at 5 -min intervals show $0.00,0.24,0.45,0.35,0.23,0.17,0.05$, and 0.01 in for eight consecutive recordings. Values of this magnitude are not uncommon. On July 14,1974 , five 5 -min intervals were recorded as $\mathbf{0 . 0 2}$, $0.13,0.65,0.35$, and 0.00 . Again, on August 15, 1976, precipitation of $0.02,0.30,0.60,0.58,0.48,0.07$, and 0.01 was recorded over seven 5-min intervals. Other data show that rainfall can be more evenly distributed. At the same locality, on August 7, 1974, 3 in of rain fell in 3 $\mathrm{hr}$; the maximum precipitation recorded in one 5-min interval was 0.25 in (E.J. Inman, unpub. precipitation data, 1973-1978).

Precipitation data for 1-min intervals from Panola Mountain State Park about 16 mi east of Atlanta (J.B. Shanley, unpub. data, 1988) show distribution patterns of precipitation during 5- and 10-min thunderstorms. One storm from 1:25 to 1:34 p.m. on July 27,1988 , shows the following distribution (in inches of rainfall): $0.02,0.04,0.07,0.08,0.10,0.08$, $0.04,0.07,0.02,0.01$. A 22-min interval during a storm from 8:50 to 9:12 p.m. on September 8, 1987, showed a more sustained level of activity but did not reach the intensity of the July 27,1988 , storm: $0.01,0.05,0.06$, $0.05,0.06,0.04,0.06,0.07,0.08,0.05,0.05,0.04,0.03,0.03,0.03$, $0.02,0.01,0.02,0.03,0.02,0.02,0.01$. A July 31,1987 , storm from 9:00 to 9:13 p.m. shows that relatively high rates can be sustained for several minutes: $0.06,0.09,0.10,0.08,0.06,0.05,0.07,0.08,0.08$, $0.09,0.03,0.04,0.04$.
} 


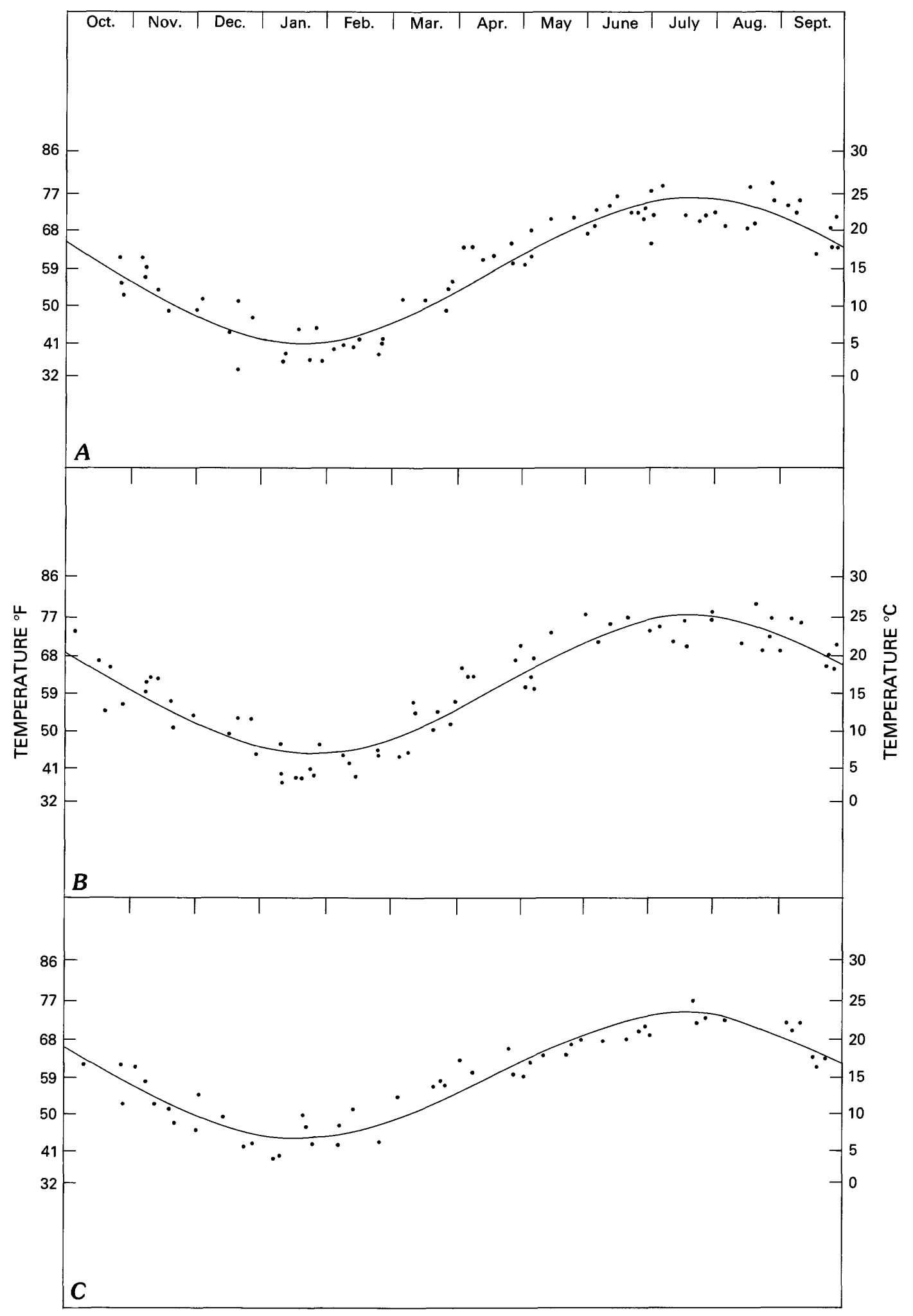

Figure 2. Least-squares sinusoidal fit of long-term periodic temperatures (Dyar and Stokes, 1973). A, Flint River near Griffin, Ga.; B, Potato Creek near Thomaston, Ga.; C, Mountain Oak Creek near Hamilton, Ga. Town locations are shown in figure $1 A$. 


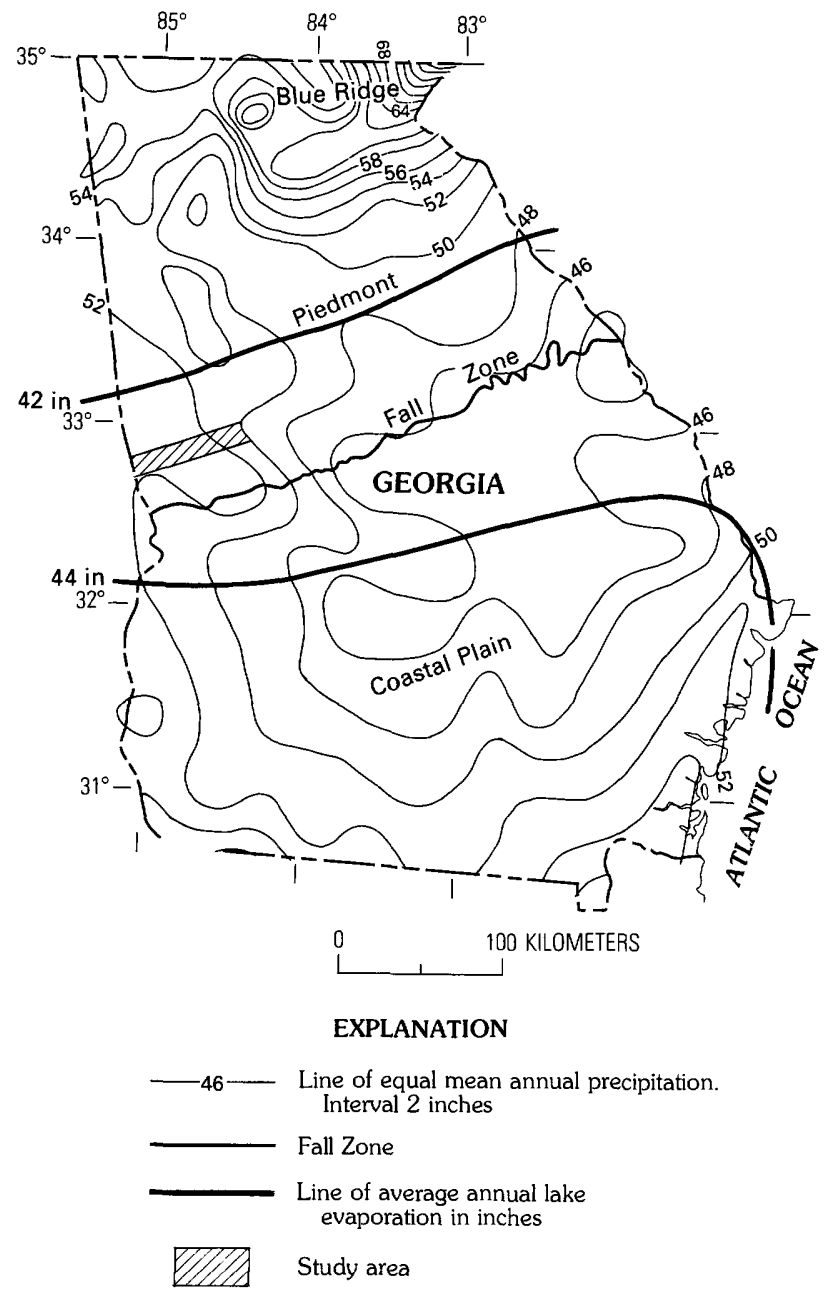

Figure 3. Isopleths of mean annual precipitation and estimated mean annual lake evaporation for Georgia (modified from Kohler and others, 1959; Carter and Stiles, 1983).

Carter and Stiles (1983) showed that the western half of Georgia is wetter than the eastern half and that central Georgia receives less rainfall than either northern or southern Georgia (fig. 3). Plummer (1983) studied historical records for any data pertaining to weather and described a more detailed pattern of precipitation along a south-tonorth transect from Tallahassee, Fla., to Chattanooga, Tenn. He stated (Plummer, 1983, p. 53):

...precipitation decreases northward to a place just beyond Columbus (from Tallahassee); then it increases slightly around Pine Mountain and decreases northward toward Carrollton; lastly it increases more northward toward the mountains and Chattanooga.

This pattern of precipitation implies a local orographic effect as air moves from south to north-from the hotter and drier Coastal Plain across the cooler high ridges in the Pine Mountain area. At present, there are not an adequate number of precipitation monitoring stations to verify this effect.
Such an orographic effect operating over long time periods would have influenced the development of vegetation and landforms on the southern and northern slopes of the ridges. Some suggestion of this influence can be seen in the present floral assemblages and in the pattern of preserved surficial deposits. The flora and landform patterns are discussed in following sections of this report.

\section{Paleoclimate}

The interpretation of soil development requires information about paleoclimate. We have no direct paleoclimate information, such as palynologic data, from dated deposits or surfaces in the immediate area. Regionally, however, there is evidence for variable paleoclimate through the Quaternary. Markewich and Markewich (1994) found evidence for periods of Holocene aridity in southern Georgia. Regional palynologic analysis (Delcourt and Delcourt, 1985) from the Southeastern United States provides evidence of a cooler and dryer climate in the late Pleistocene correlated with Laurentide glaciation; however, no periglacial effects on the landscape have been found this far south of the glacial border. Presumably, there were numerous periods of cooler and (or) drier climate through the Pleistocene associated with glaciation/deglaciation cycles. We have no evidence for the frequency or duration of such periods. We assume that the changes in the regional patterns of precipitation, wind, and temperature would affect the entire study area; that is, there were no major climatic gradients associated with Pine Mountain. On the basis of the evidence for an orographic effect presented in the previous section, we assume that the microclimatic pattern for the Pine Mountain area has been constant as long as Pine Mountain has been a positive relief feature of the landscape.

\section{Vegetation}

Comparisons of soil development must take vegetation differences into account. The present plant communities in the Piedmont and on Pine Mountain are distinctly different.

The predominant vegetative growth in the Piedmont is deciduous hardwoods, whereas needle-leaf evergreens predominate in the Coastal Plain and on the high, narrow ridges of Pine Mountain. More specifically, the present vegetative growth in the Piedmont is modified regrowth deciduous hardwoods and hardwood-pine mixtures. The floral community of Pine Mountain is different than that of the surrounding Piedmont. Pine Mountain was probably named for its communities of longleaf pine, which are still evident on the very top of and on south-facing slopes of the quartzite ridges. The short-leaf loblolly pine is the dominant pine on other aspects, where it is cooler and commonly wetter. 
The Flint River Water Gap, where the Flint River flows through Pine Mountain (fig. $1 B$ ), exhibits a remarkable array of both northern and southern floral elements occurring together. ${ }^{9}$ Harper $(1903 a, b)$ noted the interesting admixture of Piedmont, mountain, and Coastal Plain species in the Pine Mountain area. Seventy years later, Jones (1974) wrote on the uniqueness of the phytogeography and flora of the region. Wharton (1977), in his study entitled "The Natural Environments of Georgia," best summarized the unique floral and faunal characteristics of the Pine Mountain area.

In his description of the vegetative communities associated with ravines and narrow canyons of the Pine Mountain belt, Wharton (1977, p. 151-153) gave the following descriptions:

Ravine Forest of Mixed Affinities: The ravines, slopes, and bluffs of the Pine Mountain area (Meriwether and Harris counties) support classic examples of these environments with their curious mixture of mountain and Coastal Plain plant life, as well as mixtures of Piedmont and Coastal Plain animal life....ravines are cool and moist, with small streams and steep sides....In one Harris County ravine the principal trees were northern red oak, beech, chalk maple, Florida maple, and an ash. The understory contained both silver bells (Halesia caroliniana), buckthorn (Rhamnus sp.), sweet shrub, and mulberry. This is the most northern area where I have found the needlepalm (Rhapidophyllum). Herbs of note were hepatica, alumroot (Heuchera americana), doll's eyes ginseng (Panax quinquefolia), the latter being a new record this far south. A north-facing river bluff bore a forest of white oak, buckeye, red elm, poplar, Florida maple, and mockernut hickory. The shrub layer had red bay, witch hazel, Amphora fruitcosa, and mountain laurel. It is quite odd to see mountain laurel side by side with Coastal Plain red bay.

Dripping Rock ravine between Dripping Rock Falls and the Flint River (Upson County) [in the area of the Flint River Water Gap] is another example of disjunct northern and southern floral elements together. The following plants were either dominant or common: Trees-(D) beech, black gum, sourwood, sweet bay (Magnolia virginiana), American holly. Shrubs-Carolina rhododendron (Cyrilla racemosa), myrtle (Mrica heterphylla), (D) Hercules'-club (Aralia spinosa), mountain laurel, sweet shrub, greenbriers (Smilax walteri, S. laurifolia). Herbs-lousewort (Pedicularis), Ligusticum canadense, yellowroot, Indian cucumber (Medeola virginiana), Siliphium compositum, small green wood orchid (Habenaria clavellata), Indian plantain (Cacalia atriplicifolia), (D) cinnamon fern, (d) chain fern, southern lady fern, bracken fern, royal fern, angelica (Angelica venenosa).

\footnotetext{
${ }^{9}$ The entire area of the Flint River Water Gap has been recommended by Radford and Martin (1975) as a Natural Landmark called the "Flint River Water Gap Wilderness Area." They list it as one of three outstanding sites in the Piedmont of eastern America when the following criteria are considered: community and species diversity; endemic, rare, and disjunct species; edaphics; topography; and geology.
}

Wharton (1977, p. 159-161) also provided descriptions of the forests present on the high ridges of the Pine Mountain belt:

Pine-Broadleaf Deciduous Subcanopy Xeric Forests: There appear to be two subtypes of this forest. The most spectacular is on the Hollis Quartzite on the high ridges of Pine Mountain. It is similar to the Broadleaf Deciduous Subcanopy Forest of the Coastal Plain. Another type has a more diverse understory of deciduous trees and shrubs and occurs on dry ridges throughout the western Piedmont north of Pine Mountain....The Pine Mountain localities have typically a longleaf pine overstory and a blackjack oak understory, instead of turkey oak as in Coastal Plain environments. The common sandhill sticky foxglove (Aureolaria pectinata) is common. On ridges and westfacing bluffs along the Flint River there are still some good stands of longleaf pine...Somewhat surprisingly, this soil (on Pine Mountain ridges) is an adequate habitat for the burrowing coral snake....It is quite unusual to find coral snakes this far north in the Piedmont. Most have come from the narrow sandy Flint River floodplain.... PineHardwood Xeric Ridge And Slope Forests: This type of dry forest occupies much of Pine Mountain.... Some of these ridges should seemingly grow longleaf pine but for some reason (soil, infrequent fire, lack of seed source) they maintain other species of pine along with oaks and hickories. Sometimes shortleaf or loblolly pines completely dominate the ridge tops. In rocky situations chestnut oak (Quercus prinus) tends to dominate....

As we have with paleoclimate, we can only assume that the differences in relief, parent material, and microclimate have affected the vegetation similarly through the Quaternary.

\section{GEOLOGIC AND GEOHYDROLOGIC SETTINGS}

Hack (1982) referred to the Pine Mountain area of Georgia and Alabama as the Pine Mountain belt and included it as a subdivision of the Piedmont Lowlands subprovince of the Piedmont physiographic province. Structurally, the Pine Mountain belt of Hack (1982) has been identified as a window of older Precambrian rocks in a younger Precambrian or Paleozoic terrain (Clarke, 1952; Higgins and others, 1988). The Pine Mountain belt or window is a structurally complex, ridge-forming anticlinorium that extends $100 \mathrm{mi}$ southwestward from Barnesville, Ga., to Notasulga, Ala. (fig. 1A). Linear bands of high, narrow ridges, broad valleys, deeply incised canyons, steep cliffs, and numerous springs make the area, which is more similar to the Valley and Ridge and Blue Ridge physiographic provinces, unique in the southern Piedmont physiographic province. In Georgia, the prominent semicontinuous ridge that trends from west of Hamilton to just east of Manchester is locally referred to as "Pine Mountain" (fig. $1 B$ ). Thus, Pine Mountain encompasses numerous ridges of varying length, several of which have local names.

In his relief map of the Piedmont and Blue Ridge provinces (fig. 4), Hack (1982) showed the Pine Mountain 


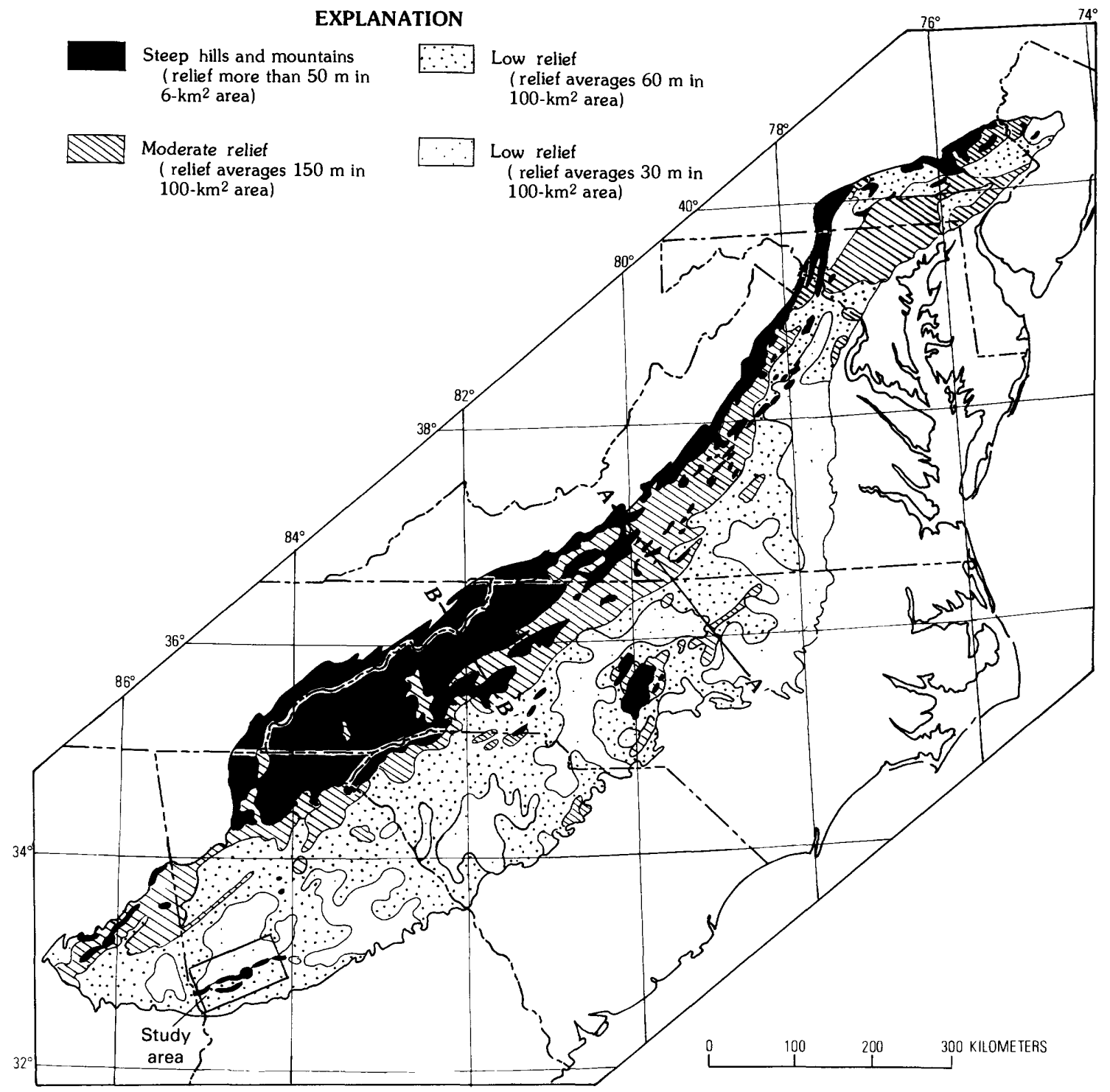

Figure 4. Relief of the Piedmont and Blue Ridge physiographic provinces of the Eastern United States (Hack, 1982). Areas are based on the number of $100-\mathrm{ft}$ contours within $100-\mathrm{km}^{2}$ areas, as shown on topographic maps at a scale of 1:250,000.

area of Georgia to have relief similar to that of the high Blue Ridge (greater than $50 \mathrm{~m}$ in a $6-\mathrm{km}^{2}$ area). This relief is in contrast to that of the adjacent Piedmont north of Pine Mountain (60 m in a $100-\mathrm{km}^{2}$ area). Ridge-crest altitudes in the study area range between 900 and $1300 \mathrm{ft}$. Valley altitudes are between 500 and $800 \mathrm{ft}$.

\section{Geology}

Structurally, the Pine Mountain belt or window is expressed as a large anticlinorium bounded on the north by the Towaliga fault zone and on the south by the Oak Mountain fault, which has been referred to as the Achumchee fault by Higgins and others (1988). Hewett and Crick- may (1937) mapped the Warm Springs 15-min quadrangle (between long $84^{\circ} 30^{\prime}$ and $84^{\circ} 45^{\prime} \mathrm{W}$. and lat $32^{\circ} 45^{\prime}$ and $33^{\circ} 00^{\prime}$ N.), which includes part of the Pine Mountain window. The area of the Pine Mountain window between Thomaston and Indian Grave Mountain was first mapped in detail by Clarke (1952) as part of the Thomaston 15-min quadrangle (between long $84^{\circ} 15^{\prime}$ and $84^{\circ} 30^{\prime} \mathrm{W}$. and lat $32^{\circ} 45^{\prime}$ and $33^{\circ} 00^{\prime}$ N.). In the 1970 's and early 1980 's, the stratigraphy of the area was revised by a number of geologists. Higgins and others (1988) have included a revised stratigraphy of the Pine Mountain structural window, which is a modified combination of the nomenclature used by Hewett and Crickmay (1937), Bentley and Neathery (1970), Sears and others (1981), Schamel and Bauer 
(1980), Schamel and others (1980), and Sears and Cook (1984).

Dominant rock types of the outer Piedmont of westcentral Georgia and east-central Alabama include crystalline metasediments, metavolcanics, melange sequences, and younger granitic intrusives. The Pine Mountain window in Georgia is composed of two units-Middle Proterozoic granulitic rocks and overlying late Precambrian quartzites and schists of the Pine Mountain Group. The Pine Mountain Group is comprised of the Hollis Quartzite, the Manchester Schist, the Mountain Creek Formation, and the Chewacla Marble (not mapped in Georgia) (Higgins and others, 1988). The Hollis Quartzite underlies the high ridges and is the most common clast lithology in the surficial deposits.

Hewett and Crickmay (1937) described upper and lower units of the Hollis as thin bedded, porous, flexible, jointed, and friable. They referred to these sections of the Hollis as itacolumite, which is the most common lithotype exposed in the study area. Compositionally, the Hollis varies from orthoquartzite to a muscovitic quartzite conglomerate. Locally, the Hollis is feldspathic. Original bedding may be evident, or else what appears to be bedding could be the penetrative layer-parallel schistosity parallel to the axial surfaces of the isoclinal folds (Sears and others, 1981). No internal bedforms have been identified, except at one locality where Clarke (1952, p. 22) described crossbeds from what he mapped as "the quartzite member of the Manchester formation," which is probably the Hollis Quartzite.

Hewett and Crickmay (1937) referred to the middle unit of the Hollis as being massive and impervious. It is this facies of the Hollis that is exposed on ridge crests on the western limit of the study area, near the town of Hamilton. The orthoquartzite has been incorporated into the large debris flows and colluvial aprons in that area.

In the study area, a few isolated pods of early Cenozoic fluvial sediments have been preserved in structurally low positions. These bauxitic and kaolinitic sediments (see table 1) have been referred to as the Republic Mine beds (Reinhardt and others, 1984a, b). Reinhardt and others (1984a) indicated that minor cross faults associated with the Towaliga fault have deformed the oldest of three surficial deposits that overlie the downfaulted sediments with a minimum of $10 \mathrm{ft}$ displacement. Reinhardt and others (1984a) considered the faulting of the oldest surficial sediments to be syngenetic with faulting of the Republic Mine beds. They indicated that the second and third fan deposits could be associated either with later tectonism or with climate change.

Later Cenozoic sediments comprise much of the surface materials and are expressed as alluvial fans and terraces, landslides, debris flows, and colluvial aprons. These deposits are described in the same sections as their associated soil and weathering profiles.

\section{Geohydrology}

The Pine Mountain area of Georgia is characterized by numerous springs that vary in discharge from less than 1 to more than $800 \mathrm{gal} / \mathrm{min}$. Temperature variation is from 60 to $88^{\circ} \mathrm{F}$. The concept of a "warm" spring is relative to the near-surface ground-water temperatures in an area. Hewett and Crickmay (1937, p. 4) reported that "the average temperature of the water in 36 wells in the lowland adjacent to Pine Mountain area is $62.1{ }^{\circ} \mathrm{F}$." Near-surface water temperatures reflect the area's mean annual temperature, which ranges between 60 and $64^{\circ} \mathrm{F}$. In this study area, temperatures above $70^{\circ} \mathrm{F}$ appear to be common to springs having relatively high discharge rates (more than $100 \mathrm{gal} / \mathrm{min}$ ). Most of the springs, but not all, are located on the northern side of Pine Mountain (fig. 1A). McCallie (1913) and Hewett and Crickmay (1937) studied the more important springs in the area. Some of their data are summarized in the following sections. Specific data are shown in table 2. Other data from Hewett and Crickmay (1937) and some unpublished data are given in tables 2 and 3.

\section{Warm Springs}

Warm Springs is the only known warm spring that emanates from a crack in the Hollis Quartzite. Other warm springs in the area rise frorn either the Manchester Schist or surficial units. Hewett and Crickmay (1937) measured the temperature and volume of water of Warm Springs at the source, where it is controlled for use at the rehabilitation center; other springs were measured as access allowed. The following excerpt from Hewett and Crickmay (1937, p. 5) is included to show the detail of work that they attempted in the area:

From December 14, 1933, to June 30, 1935, the discharge under control ranged from 594 to 678 gallons a minute. Measurements of the discharge of all the minor sources during the same period ranged from 233 to 294 gallons a minute. The total discharge of all sources, therefore, ranged from 844 to 914 gallons a minute. Precise measurements of the temperature of the Warm Springs water as it issues from the ground at its main east and west sources were made on seven different days in 1933, 1934, and 1935 by using a platinum resistance thermometer. At the east source the temperature on different days ranged from $87.7^{\circ}$ to $88.2^{\circ} \mathrm{F}$, and at the west source from $87.1^{\circ}$ to $87.5^{\circ} \mathrm{F}$

Water chemistry is given in table 2, reproduced from Hewett and Crickmay (1937, p. 17, 18, 21). Although warm spring waters have a greater content of calcium and magnesium bicarbonate (fig. 5) than cold spring waters do, the overall composition of all spring waters suggests that they are essentially rain water and contain no component of water from an igneous or volcanic source. Hewett and Crickmay (1937) attributed the 88 to $89^{\circ} \mathrm{F}$ temperature of Warm Springs to a normal geothermal gradient of about 1 ${ }^{\circ} \mathrm{F}$ per $100 \mathrm{ft}$ for water moving downward and then upward along bedding planes of the Hollis Quartzite. 
Table 1. Analyses (in percent) of primary and sedimentary kaolin and bauxite from the area around Warm Springs, Meriwether County, Georgia (Smith, 1929, p. 453, 454, and 458)

[No entry indicates value was not given by Smith (1929)]

\begin{tabular}{|c|c|c|c|c|c|c|}
\hline & \multirow{2}{*}{$\begin{array}{l}\text { Bauxite from } \\
\text { Warm Springs } \\
\text { bauxite mine }\end{array}$} & \multicolumn{3}{|c|}{$\begin{array}{l}\text { Kaolin and bauxite from prospect wells } \\
\text { near Warm Springs bauxite mine }{ }^{1}\end{array}$} & \multicolumn{2}{|c|}{$\begin{array}{l}\text { Primary or residual kaolin from property } \\
3 \text { mi south of Durand and } 4 \text { mi west of } \\
\text { Warm Springs (Smith, 1929, p. 458) }\end{array}$} \\
\hline & & $A^{2}$ & $B^{3}$ & $\mathrm{C}^{4}$ & $\mathrm{D}$ & $E$ \\
\hline $\mathrm{SiO}_{2} \ldots \ldots$ & 19.05 & 44.76 & 47.74 & 46.34 & 75.02 & 57.30 \\
\hline $\mathrm{Al}_{2} \mathrm{O}_{3} \ldots \ldots$ & 51.28 & 38.00 & 36.64 & 36.40 & 17.00 & 30.58 \\
\hline $\mathrm{Fe}_{2} \mathrm{O}_{3} \ldots \ldots$ & .48 & 2.35 & 1.19 & 1.72 & 1.57 & 1.41 \\
\hline $\mathrm{TiO}_{2} \ldots \ldots$ & 1.71 & 1.08 & 1.17 & 1.80 & .72 & 1.53 \\
\hline Sand ....... & & .97 & 13.15 & 9.91 & 58.60 & 26.17 \\
\hline
\end{tabular}

${ }^{1} \mathrm{~A}$, Stiff, semi-hard, light-gray and dark bluish-gray kaolin from a prospect well $50 \mathrm{ft}$ north of Warm Springs bauxite mine (sample taken at depth between 12 and $18 \mathrm{ft}$ ); B, hard, white, sandy, nodular bauxitic clay from a prospect well $600 \mathrm{ft}$ west of Warm Springs bauxite mine and in line with it (sample taken below depth of $4 \mathrm{ft}$ ); $\mathrm{C}$, stiff, semi-hard, white to pink kaolin from prospect pit $10 \mathrm{ft}$ north of location $B$ (sample taken at depth of about $12 \mathrm{ft}$ ).

${ }^{2}$ Typical kaolin.

${ }^{3}$ Sandy bauxitic clay. If the percentage of sand is subtracted from the total analysis and the percentage of alumina recalculated to a basis of 100 percent, the clay is 42.27 percent $\mathrm{Al}_{2} \mathrm{O}_{3}$.

${ }^{4} \mathrm{Sandy}$, slightly bauxitic clay. If the percentage of sand is subtracted from the total analysis and the percentage of alumina recalculated to a basis of 100 percent, the clay is 40.42 percent $\mathrm{Al}_{2} \mathrm{O}_{3}$.

${ }^{5} \mathrm{D}$, Grab sample from material thrown out a a $15-\mathrm{ft}$ prospect well; E, grab sample from outcrop in bank of road.

\section{Cold Spring}

Cold Spring is a name given to four springs that lie in close proximity about $1 \mathrm{mi}$ southeast of Warm Springs. The four individual springs are Cold Spring, North Springs, and South Springs No. 1 and No. 2. All the

Table 2. Discharge and temperature data from several springs in the area of Pine Mountain, Georgia (modified from Hewett and Crickmay, 1937)

$[-$, not shown in fig. $1 A]$

\begin{tabular}{|c|c|c|c|}
\hline Spring & $\begin{array}{c}\text { Location } \\
\text { no. } \\
\text { (fig. 1A) }\end{array}$ & $\begin{array}{l}\text { Discharge } \\
\text { from all } \\
\text { sources } \\
\text { (gal/min) }\end{array}$ & $\begin{array}{c}\text { Temperature } \\
\text { of main } \\
\text { source } \\
\left({ }^{\circ} \mathrm{F}\right)\end{array}$ \\
\hline \multicolumn{4}{|c|}{ Warm springs $\left(>66^{\circ} \mathrm{F}\right)$} \\
\hline Warm Springs. . & 1 & $844-914$ & $87-88$ \\
\hline Parkman Pond (Springs) .... & 2 & $50-100$ & 76.6 \\
\hline Brown's Spring ............ & 3 & $15-30$ & 69 \\
\hline Thundering Spring. . . . . . . & 4 & 380 & 74 \\
\hline Barker Spring ...... & 5 & 30 & 74 \\
\hline Lifsey Spring . . ....... & 6 & 83 & 78 \\
\hline Taylor Spring (Clearwater).. & 7 & 385 & 75 \\
\hline \multicolumn{4}{|c|}{ Cold springs $\left(<66^{\circ} \mathrm{F}\right)$} \\
\hline Cold Spring. & - & $1282-1822$ & 64 \\
\hline North Spring........... & - & $238-451$ & \\
\hline South Springs $1,2 \ldots \ldots \ldots$ & - & 50 & \\
\hline Cold Spring and seepage. & - & $1050-1320$ & \\
\hline Trammel's Spring .......... & 9 & 100 & 62 \\
\hline Blue Spring . . . . . . . . . . & 8 & $282-367$ & 64 \\
\hline Chalybeate Springs . . . . . . . & 3 & $12-24$ & $62-64$ \\
\hline Oak Mountain Spring....... & - & $0.54-0.94$ & $60-64$ \\
\hline White Sulphur Springs..... . . & - & $0.65-1.62$ & $62-63$ \\
\hline
\end{tabular}

springs are located on land owned by and used as a fish hatchery by the U.S. Government. This hatchery has been in continuous operation for 60 years. Hewett and Crickmay (1937) found that Cold Spring and North Spring were related and that the two southern springs were separate outlets for the same source but that the South Springs were not related to either Cold or North Springs.

Hewett and Crickmay (1937) estimated the combined discharge of South Springs No. 1 and No. 2 to be about 50 $\mathrm{gal} / \mathrm{min}$, the total discharge from the four sources of Cold Springs being averaged as $1,500 \mathrm{gal} / \mathrm{min}$. Water from these springs is used as the municipal water supply for the town of Warm Springs and for the fish hatchery. The remainder of the waters constitute the main source for Cold Spring Branch. Analyses of Cold Spring are given in table 3.

\section{PARENT MATERIAL AND ASSOCIATED SOIL AND WEATHERING PROFILES}

Soil $^{10}$ and weathering profiles sampled for this study have developed in situ on metasedimentary rocks and on

\footnotetext{
${ }^{10}$ All soils described, sampled, and (or) analyzed in the Pine Mountain area are classified as Ultisols-Udults and Paleudults-which are common in humid-temperature areas that have a seasonal precipitation deficit. In the Piedmont and Coastal Plain of Georgia, evapotranspiration is greater than precipitation for at least 3 mo of the year. The area is in the thermic soil temperature regime (mean annual soil temperature from 15 to $22{ }^{\circ} \mathrm{C}$ at $50 \mathrm{~cm}$ depth), and the difference between mean summer and mean winter soil temperatures is more than $5{ }^{\circ} \mathrm{C}$. The soil moisture regime is udic (that is, in most years, the soil moisture control section is not dry in any part for as long as 90 days cumulative).
} 
Table 3. Analytical data from a cold spring at the National Fish Hatchery at Warm Springs, Georgia [ND, no data; - , not detected; S.D., standard deviation; S.E., standard error]

\begin{tabular}{|c|c|c|c|c|c|c|c|c|}
\hline Month & $\mathrm{pH}$ & Hardness & $\begin{array}{c}\mathrm{NO}_{2} \\
(\mathrm{ppm})^{1}\end{array}$ & $\begin{array}{c}\mathrm{NO}_{3} \\
(\mathrm{ppm})^{1}\end{array}$ & $\begin{array}{c}\mathrm{NH}_{3} \\
(\mathrm{ppm})^{1}\end{array}$ & Conductance & $\begin{array}{c}\text { Temperature } \\
\left({ }^{\circ} \mathrm{C}\right)\end{array}$ & $\begin{array}{l}\text { Dissolved } \\
\text { oxygen }\end{array}$ \\
\hline March ......... & 3.9 & 4.0 & - & - & - & 25 & 17 & 9.5 \\
\hline June $\ldots \ldots \ldots \ldots$ & 4.3 & 2.0 & - & - & - & 25 & ND & ND \\
\hline July............ & 4.4 & 4.0 & - & - & 0.06 & 20 & 17.8 & 12.0 \\
\hline Aug............. & 4.3 & 10.0 & - & 0.03 & - & 25 & ND & 12.0 \\
\hline Sept............ & 3.9 & 1.6 & - & - & - & 25 & 17.8 & 7.8 \\
\hline 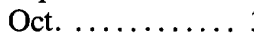 & 3.7 & 6.0 & 0.004 & 1.0 & 0.03 & 20 & 17.8 & 11.0 \\
\hline \multirow[t]{2}{*}{ Nov........... } & 4.1 & 6.0 & 0.010 & - & - & 20 & 17.8 & 7.0 \\
\hline & $\mathrm{pH}$ & Hardness & $\underset{(\mathrm{ppm})^{1}}{\mathrm{NO}_{2}}$ & $\begin{array}{c}\mathrm{NO}_{3} \\
(\mathrm{ppm})^{1}\end{array}$ & $\begin{array}{c}\mathrm{NH}_{3} \\
(\mathrm{ppm})^{1}\end{array}$ & Conductance & $\begin{array}{c}\text { Temperature } \\
\left({ }^{\circ} \mathrm{C}\right)\end{array}$ & $\begin{array}{c}\text { Dissolved } \\
\text { oxygen }\end{array}$ \\
\hline \multicolumn{9}{|l|}{ No. of } \\
\hline observations... & 7 & 7 & 7 & 7 & 7 & 7 & 5 & 6 \\
\hline Mean ........... & 4.1 & 4.8 & 0.002 & .19 & 0.01 & 23 & 17.6 & 9.9 \\
\hline S.D. .......... & .3 & 2.9 & .004 & .38 & .02 & 3 & .4 & 2.1 \\
\hline S.E. . . . . . . & .1 & 1 & .001 & .14 & .01 & 1 & .2 & .9 \\
\hline
\end{tabular}

${ }^{1}$ National Fish Hatchery (unpub. data, 1981) supplied the following analyses: Fe (total), 0.05 ppm; Na, 0.90 ppm; K, 0.40 ppm; total alkalinity (as $\mathrm{CaCO}_{3}$ ), $3.00 \mathrm{ppm} ; \mathrm{SO}_{4}, 0.20 \mathrm{ppm} ; \mathrm{NH}_{3}, 0.13 \mathrm{ppm}$.

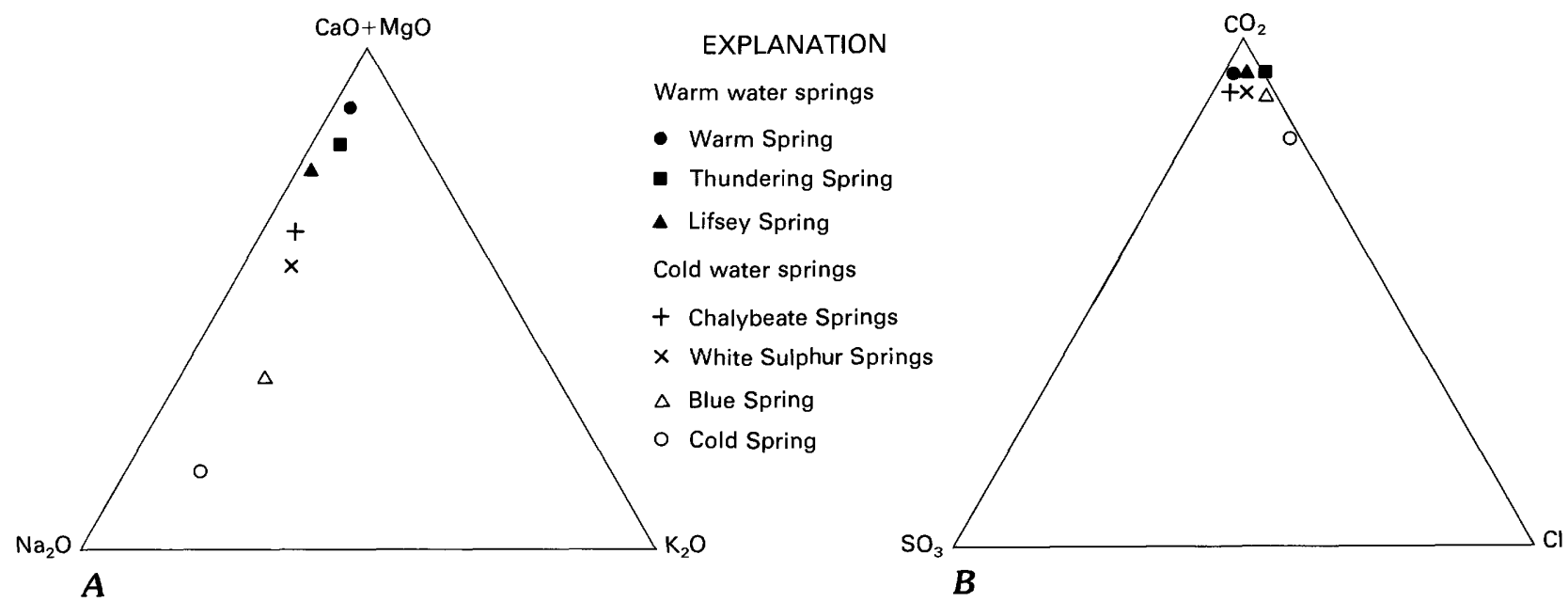

Figure 5. Cation $(A)$ and anion $(B)$ compositions of cold- and warm-water springs in the Pine Mountain area of Georgia including data from McCallie (1913) and Hewett and Crickmay (1937).

many different surficial deposits such as stream alluvium, landslide debris, and alluvial fans. A description of each sampling site, the parent material, and the soil and (or) weathering profile(s) is given in the following sections. Locations of sample sites are shown in figures $1 B, 6 A-E$, and 14. Specifics on locations are given in table 4.

Analytical methods and references to those methods are presented in table 5. Data obtained from characterization of these soils are presented in tables 6 through 14 (see p. E47) and in figures $7 A-H$ and $8 A-H$.

\section{Residual Soils in Piedmont Parent Material}

The Piedmont north of the Towaliga fault zone is composed of schist and gneiss and tabular-shaped granitic intrusives. Depth of weathering exceeds $30 \mathrm{ft}$ beneath uplands and is deeper along joints and in rocks fractured by faulting. Weathering depths in the granite are shallower than those in metamorphic rocks. We sampled and analyzed one pedon (199-001) developed on schistose metasedimentary crystalline rock north of Pine Mountain (site 1, figs. $1 B, 6 D)$. 
Table 4. Soil sampling site locations and geomorphology

[-, surface is flat, so there is no slope value. Site locations shown in fig. $1 B$ ]

\begin{tabular}{|c|c|c|c|c|c|c|c|c|c|}
\hline Site & $\begin{array}{l}\text { Soil Conservation } \\
\text { Service no. }\end{array}$ & $\begin{array}{c}\text { 7.5-min } \\
\text { quadrangle }\end{array}$ & Geomorphology & $\begin{array}{l}\text { Altitude } \\
\quad(\mathrm{ft})\end{array}$ & $\begin{array}{l}\text { Latitude } \\
\left({ }^{\circ} \mathrm{N} .\right)\end{array}$ & $\begin{array}{l}\text { Longitude } \\
\left({ }^{\circ} \mathrm{W} .\right)\end{array}$ & $\begin{array}{c}\text { Slope } \\
\text { (percent) }\end{array}$ & Aspect & $\begin{array}{l}\text { Pedologic data } \\
\text { tables }\end{array}$ \\
\hline & S84GA-199-001 & Woodbury & Piedmont & 248 & $32^{\circ} 57^{\prime} 01^{\prime \prime}$ & $84^{\circ} 37^{\prime} 17^{\prime \prime}$ & 2 & NW. & $6 A-E$ \\
\hline 2. & S84GA-231-001 & Thomaston & Mountain & 310 & $32^{\circ} 59^{\prime} 58^{\prime \prime}$ & $84^{\circ} 19^{\prime} 24^{\prime \prime}$ & 6 & SW. & $7 A-D$ \\
\hline 3. & S84GA-231-003 & Zebulon & Mountain & 342 & $33^{\circ} 00^{\prime} 11^{\prime \prime}$ & $84^{\circ} 20^{\prime} 58^{\prime \prime}$ & 5 & NE. & $8 A-C$ \\
\hline $4 \ldots$ & S84GA-231-004 & Zebulon & Mountain & 345 & $33^{\circ} 00^{\prime} 09^{\prime \prime}$ & $84^{\circ} 20^{\prime} 57^{\prime \prime}$ & 7 & NE. & $9 A-C$ \\
\hline 5. & S84GA-231-002 & Zebulon & Landslide quartzite & 250 & $33^{\circ} 00^{\prime} 58^{\prime \prime}$ & $84^{\circ} 19^{\prime} 38^{\prime \prime}$ & 10 & E. & $10 A-C$ \\
\hline $6 \ldots \ldots$ & S84GA-293-001 & Sunset Village & Fan & 287 & $32^{\circ} 57^{\prime} 19^{\prime \prime}$ & $84^{\circ} 25^{\prime} 00^{\prime \prime}$ & 3 & E. & $11 A-C$ \\
\hline $7 \ldots \ldots$ & S84GA-199-002 & Warm Springs & Fan & 288 & $32^{\circ} 53^{\prime} 05^{\prime \prime}$ & $84^{\circ} 42^{\prime} 35^{\prime \prime}$ & 3 & S. & $12 A-D$ \\
\hline $8 \ldots \ldots$ & Unnumbered & Woodbury & Terrace alluvium & 228 & $32^{\circ} 59^{\prime} 30^{\prime \prime}$ & $84^{\circ} 30^{\prime} 50^{\prime \prime}$ & 4 & - & $13 A, B$ \\
\hline
\end{tabular}

We classified this pedon (199-001) as Cecil, which is the most common soil series in the southeastern Piedmont. The Cecil is a clayey, thermic typic Kanhapludult. Characterization data for this pedon are given in tables $6 A-F$. Some data are plotted on figure $7 A$. Profile characteristics are similar to those of Hapludults developed from saprolite on the Piedmont between Alabama and Virginia (National Soil Survey Laboratory, unpub. data for computerized data base, 1940-present).

This Cecil profile has a high clay content and clay maxima of 63.3 percent at 33 to $56 \mathrm{~cm}$ depth and 39 percent within $33 \mathrm{~cm}$ of the surface. Summed clay mass ${ }^{11}$ for pedon $199-001$ is $85.4 \mathrm{~g} / \mathrm{cm}^{2}$, similar to the clay masses of other Piedmont pedons (Pavich and others, 1989). Fine silt dominates the silt fraction and increases downward to the $\mathrm{C} 1$ horizon at $154 \mathrm{~cm}$. Unlike that in Coastal Plain soils investigated by Markewich and others (1986), the fine silt maximum in pedon 199-001 occurs below the clay maximum. Fine silt is probably produced by the physical alteration of mica (see fig. 9) in the upper part of the $\mathrm{C}$ horizon. X-ray diffraction and chemistry data (fig. $8 A$, tables $6 C, D$ ) indicate that chemical alteration of mica is active above the $\mathrm{C} 3$ horizon, the result being a lower fine silt content and a higher clay content.

In the clay-sized fraction, mica is abundant (predominantly muscovite) in both the parent material and the C3 horizon $(254-304 \mathrm{~cm})$. The loss of mica above the C3 horizon is seen by petrographic and $\mathrm{X}$-ray diffraction examination (figs. $8 A$, 9). Hydroxy-interlayered vermiculite is not present in the diffraction pattern of the lower solum (horizons $\mathrm{BC}, \mathrm{B} / \mathrm{C}, \mathrm{C} 2$ ) but is present in upper horizons. In Coastal Plain soils studied by Markewich and others (1987) and in Piedmont soils studied by Pavich (1986), mica is apparently not transformed to hydroxyinterlayered vermiculite. It is possible that this vermiculite is the initial product of the weathering of the mica but does not persist owing to its transformation to other constituents.

\footnotetext{
${ }^{11}$ Clay mass is calculated from weight percent clay times bulk density (in grams per cubic centimeter) times horizon thickness (in centimeters) for each horizon. The clay mass (in grams per square centimeter) is then summed for the horizons comprising the pedon.
}

Pedogenic kaolinite is the dominant clay-sized constituent of pedon 199-001. The high kaolinite content directly affects the texture and drainage characteristics of the Bt horizon, which is much finer textured and less well drained than subjacent or superjacent horizons. This association of kaolinite with fine-textured, less well-drained $\mathrm{Bt}$ horizons has also been investigated by Markewich and others (1987) and Harris and others (1989). Gibbsite is not identifiable in the saprolitic parent material or in the soil B horizons of pedon 199-001.

Major element chemistry of pedon 199-001 (table $6 D$ ) is similar to that of pedons developed in mica schist elsewhere in the Piedmont (Pavich and others, 1989).

Table 5. Analyses, methods, and units of expression for analyses conducted at the National Soil Survey Laboratory, Lincoln, Nebraska

\begin{tabular}{|c|c|c|}
\hline Analysis & $\begin{array}{c}\text { Method } \\
\text { code }^{1}\end{array}$ & Unit of expression \\
\hline Particle size & $3 \mathrm{~A} 1$ & weight percent $<2$-mm material \\
\hline Organic carbon ..... & $6 \mathrm{~A} 1 \mathrm{C}$ & weight percent $<2-\mathrm{mm}$ material \\
\hline Dithionite-citrate.... & $6 \mathrm{C} 2 \mathrm{~A}$ & weight percent $<2$-mm material \\
\hline Iron........... & $6 \mathrm{C} 2 \mathrm{~B}$ & weight percent $<2-\mathrm{mm}$ material \\
\hline Aluminum......... & $6 \mathrm{G} 7 \mathrm{~A}$ & weight percent $<2-\mathrm{mm}$ material \\
\hline Manganese ......... & $6 \mathrm{D} 2 \mathrm{~A}$ & weight percent $<2$-mm material \\
\hline Bulk density........ & 4A1D & $\mathrm{g} / \mathrm{cm}^{3}<2-\mathrm{mm}$ material \\
\hline $\operatorname{COLE}^{2} \ldots \ldots$ & $4 \mathrm{D} 1$ & $\mathrm{~cm} / \mathrm{cm}$ whole soil \\
\hline 15-bar water........ & $4 \mathrm{~B} 2 \mathrm{~A}$ & weight percent $<2$-mm material \\
\hline $\mathrm{WRD}^{3} \ldots \ldots \ldots \ldots$ & $4 \mathrm{Cl}$ & $\mathrm{cm} / \mathrm{cm}$ whole soil \\
\hline Extractable bases ... & $5 \mathrm{~B} 5 \mathrm{~A}$ & meq $/ 100 \mathrm{~g}<2-\mathrm{mm}$ material \\
\hline \multicolumn{3}{|l|}{$\mathrm{CEC}^{4}: \ldots \ldots \ldots$} \\
\hline Sum of cations ... & $5 \mathrm{~A} 3 \mathrm{~A}$ & meq $/ 100 \mathrm{~g}<2-\mathrm{mm}$ material \\
\hline $\mathrm{NH}_{4} \mathrm{OAC} \ldots \ldots \ldots$ & $5 \mathrm{~A} 8 \mathrm{~B}$ & meq $/ 100 \mathrm{~g}<2-\mathrm{mm}$ material \\
\hline Bases $+\mathrm{A} 1 \ldots \ldots$ & $5 A 3 B$ & meq $/ 100 \mathrm{~g}<2$-mm material \\
\hline \multicolumn{3}{|c|}{ Base saturation: .... } \\
\hline Sum of cations ... & $5 \mathrm{C} 3$ & percent \\
\hline $\mathrm{NH}_{4} \mathrm{OAC} \ldots \ldots \ldots$ & $5 \mathrm{C} 1$ & percent \\
\hline \multicolumn{3}{|l|}{ pH: $\ldots$} \\
\hline $\mathrm{CaCl}_{2}$. & $8 \mathrm{C} 1 \mathrm{E}$ & negative $\log _{10}$ \\
\hline $\mathrm{H}_{2} \mathrm{O} \ldots$ & $8 \mathrm{C} 1 \mathrm{~A}$ & negative $\log _{10}$ \\
\hline
\end{tabular}




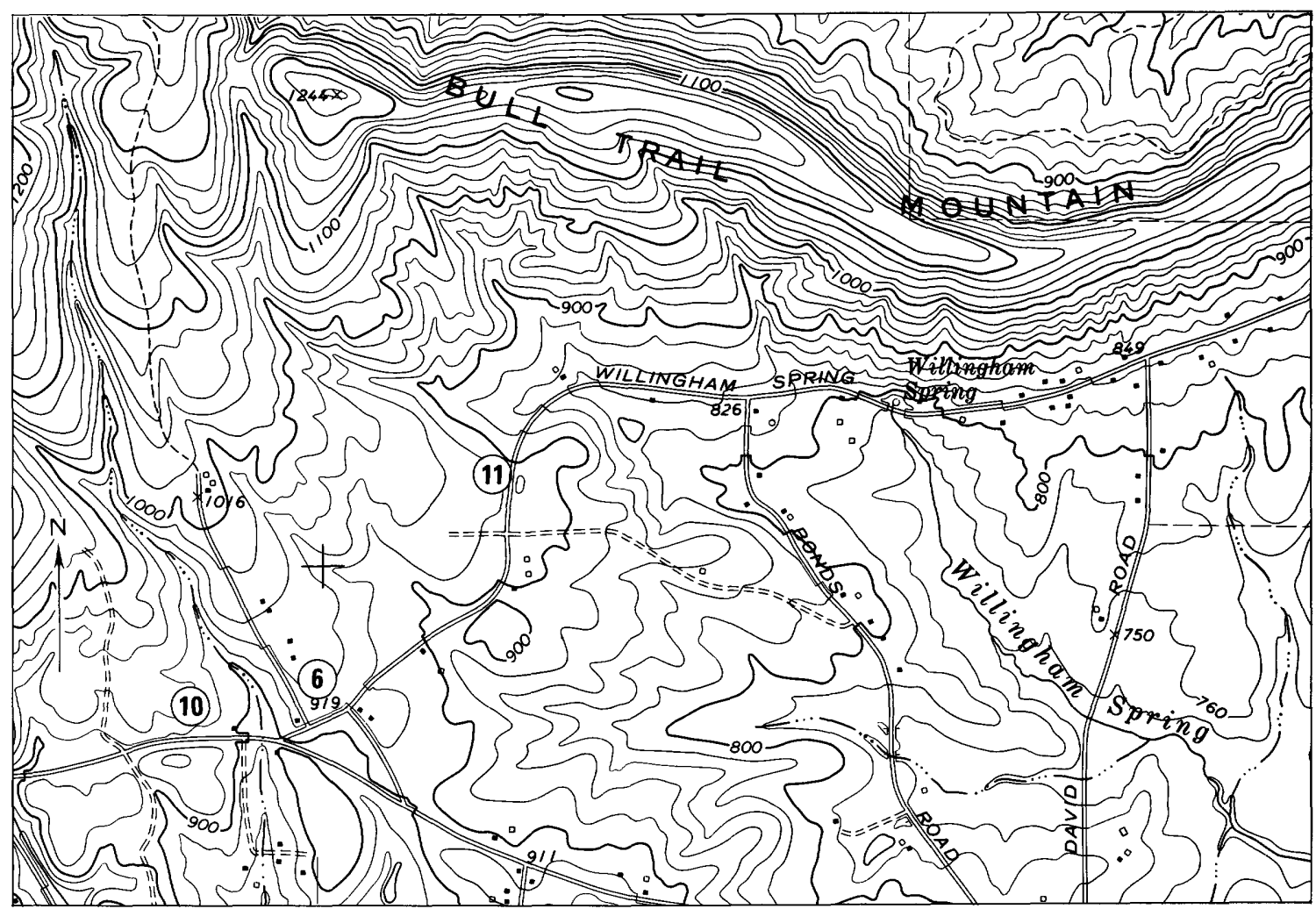

0

1 KILOMETER

Figure 6A. Soil and weathering profile sample sites. Location map is part of a 7.5 -min $(1: 24,000$ scale) Georgia quadrangle and has a 20 -ft contour interval. Site numbers are same as those given in figure $1 B$. Sites 6, 10, and 11, Sunset Village quadrangle.

Totals from X-ray fluorescence (XRF) analyses given in table $6 D$ that are significantly less than 100 percent are due to the high $\mathrm{H}_{2} \mathrm{O}$ content of the clay. The $\mathrm{A}$ horizon is highly siliceous and depleted in $\mathrm{Fe}_{2} \mathrm{O}_{3}, \mathrm{CaO}$, and $\mathrm{K}_{2} \mathrm{O}$. The $\mathrm{Bt}$ horizon is enriched in $\mathrm{Al}_{2} \mathrm{O}_{3}$ and $\mathrm{Fe}_{2} \mathrm{O}_{3}$ relative to the $\mathrm{A}$ horizon. The enrichment is due in part to translocation of clay-sized phyllosilicate and iron oxyhydroxides but mostly to leaching of silica from micas and quartz in the Bt horizon. The importance of leaching is illustrated by the BC and upper C horizons. Despite having a lower clay content than the $\mathrm{Bt}$ horizon, the upper part of the saprolite and the lower part of the pedogenic $\mathrm{B}$ horizon have extremely low $\mathrm{SiO}_{2}$ values and high $\mathrm{Al}_{2} \mathrm{O}_{3}$ and $\mathrm{Fe}_{2} \mathrm{O}_{3}$ values (tables $6 B, D$ ). The high mica content of the saprolite is partly responsible for the low $\mathrm{SiO}_{2}$ (relative to a quartzite parent material), but the $\mathrm{X}$-ray diffraction pattern (fig. 8A) shows that 10.5 - $\AA$ mica is absent above the $\mathrm{C} 2$ and has been altered for more aluminous phases (hydroxyinterlayered vermiculite or kaolinite). Thus, figure $8 A$ provides evidence that $10.5-\AA$ micas have been strongly weathered in the upper $C$ horizon, the result being a material approaching the kaolinitic composition of the $\mathrm{Bt}$ horizon but having a lower clay content. The C3 horizon reflects the composition of the aluminous schistose parent material. The greater bulk density of the Bt relative to the C3 is probably owing to the physical reorganization or repacking of minerals, as Pavich and others (1989) have seen in Virginia.

\section{Mountain Parent Material and Soils}

On the ridge locally known as Indian Grave Mountain (fig. $1 B$ ), we sampled soils developed in the Hollis Quartzite, in Hollis Quartzite overlain by colluvium, and in Hollis Quartzite that comprises the surface block of a large landslide. Weathering of feldspathic micaceous layers of the Hollis is very deep, perhaps several hundred feet. Direct evidence of deep weathering comes from open borrow pits on the crest of Indian Grave Mountain where feldspathic micaceous layers are completely altered to clay at depths greater than $50 \mathrm{ft}$ below the surface. Other indications of deep weathering are the ease of drilling 200- to 300 -ft-deep water wells in the Hollis and the ease of highway excavation by heavy machinery. Indirect evidence from Hewett and Crickmay (1937) suggests that the water feeding the hot springs is meteoric in origin and has circulated to depths of several hundred feet before surfacing at springs. 


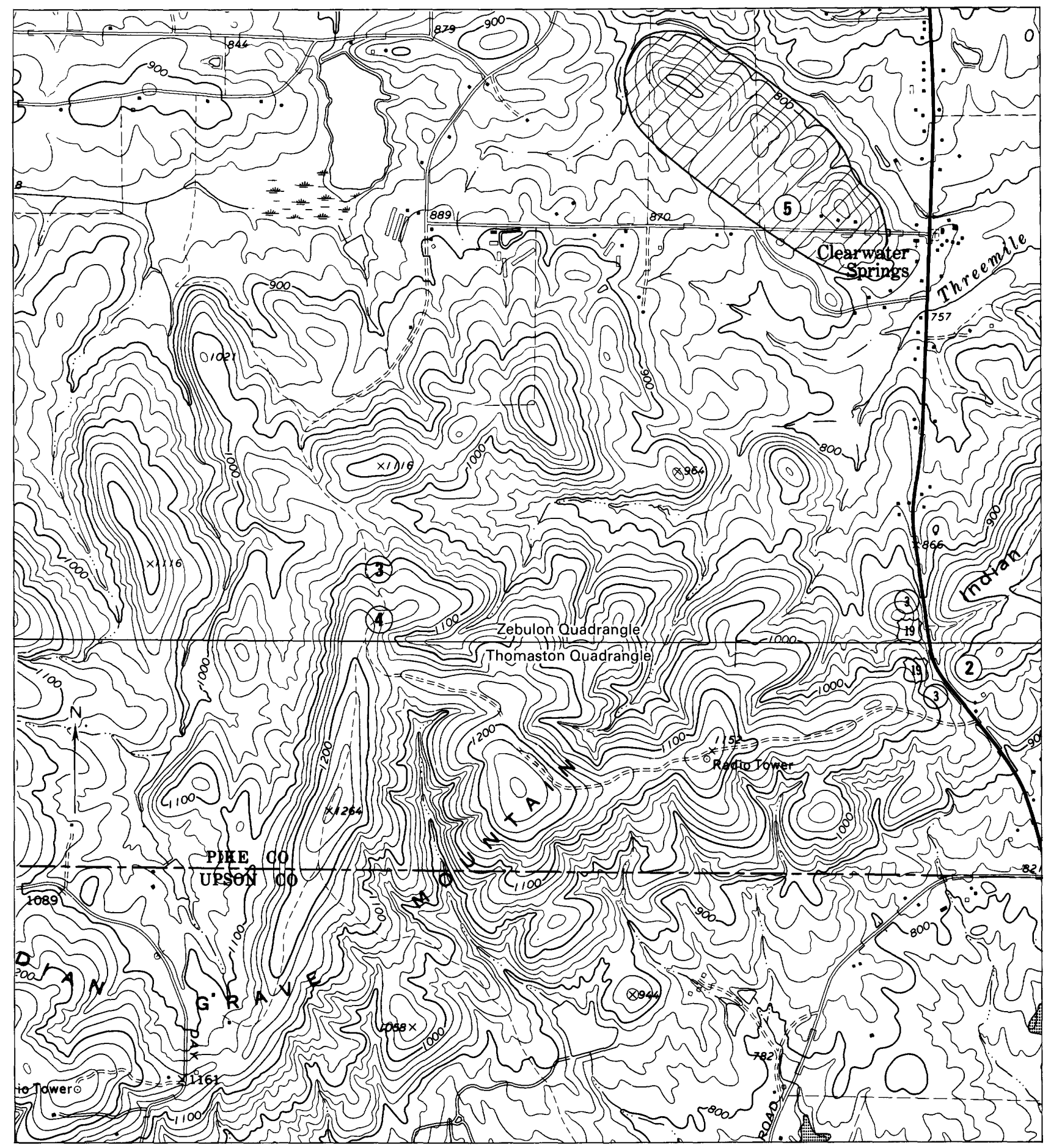

0

1 KILOMETER

Figure 6B. Soil and weathering profile sample sites. Location map is part of a 7.5-min $(1: 24,000$ scale) Georgia quadrangle and has a $20-\mathrm{ft}$ contour interval. Site numbers are the same as those given figure $1 B$. Site 2 , Thomaston quadrangle; sites 3,4 , and 5, Zebulon quadrangle. 


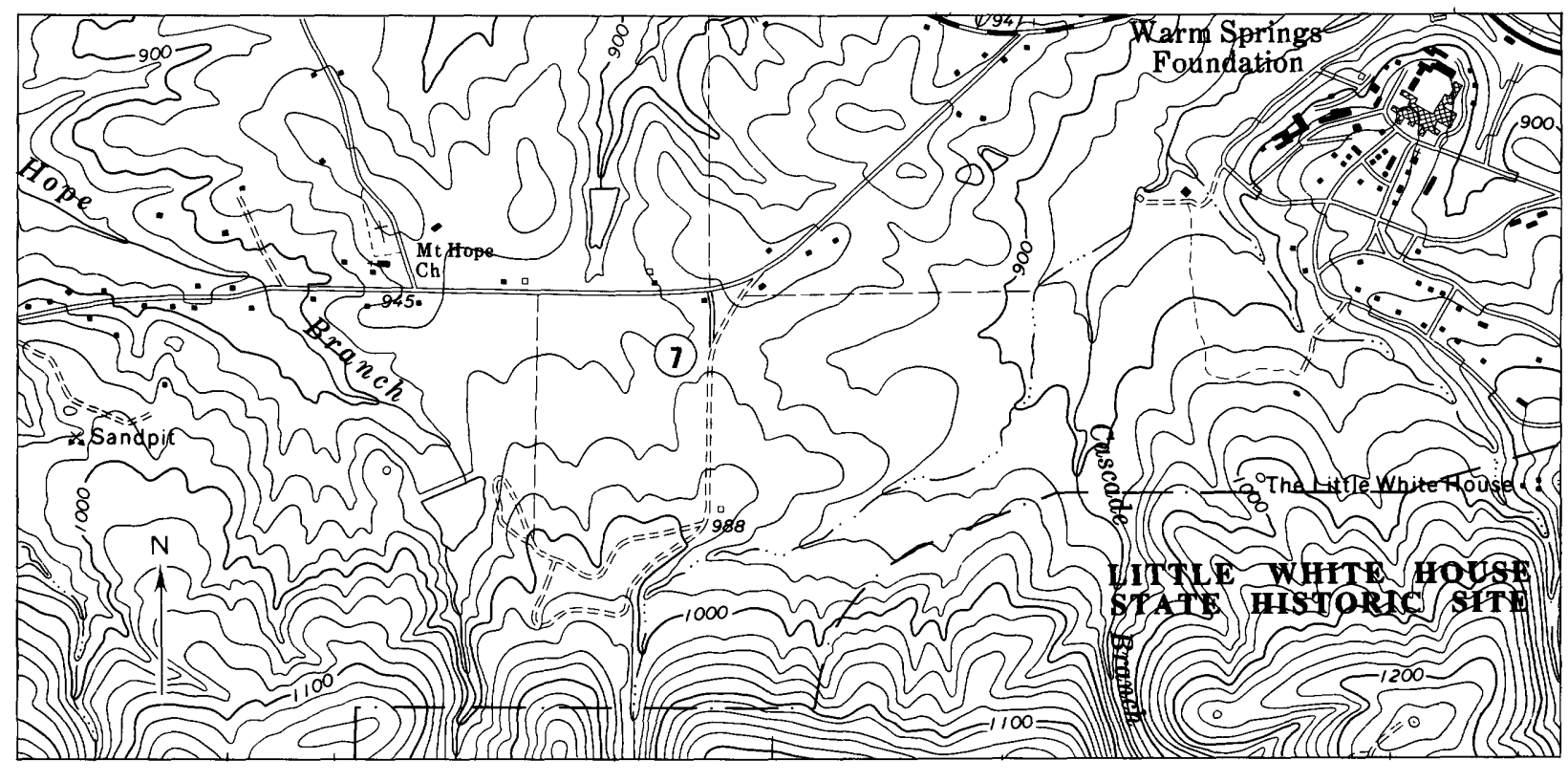

0

1 KILOMETER

Figure 6C. Soil and weathering profile sample site. Location map is part of a 7.5-min (1:24,000 scale) Georgia quadrangle and has a $20-\mathrm{ft}$ contour interval. Site numbers are the same as those given in figure $1 \mathrm{~B}$. Site $7, \mathrm{Warm}$ Springs quadrangle.

Tables $7 A, 8 A, 9 \mathrm{~A}$, and $10 A$ present the field descriptions of the pedons (sites $2,3,4,5$ on fig. $6 B$ ). Other data are given in tables $7 B-D, 8 B$ and $C, 9 B$ and $C$, and $10 B$ and $C$. Textural, cation exchange capacity, and porosity data for these pedons are plotted in figures $7 B-E$.

\section{Pedon 231-001: Quartzite Residual Soil}

Pedon 231-001 (site 2, figs. $1 B, 6 B$ ) has developed as a residual soil in the Hollis Quartzite and has the gravelly surface horizons typical of these soils. The quartzite gravel is pebble sized (0.5-3 in) and appears to have formed in place as the result of chemical and mechanical breakdown of the Hollis. The pebbles are subrounded to rounded. Pebble surfaces are pitted and have weathered to a purple-gray color. At some localities, such as along the crest of Pine Mountain south of the town of Warm Springs, these surface gravels are extensive and sufficiently thick to map as a separate unit. Hewett and Crickmay (1937, p. 30) stated that "The pebbles do not form a continuous layer but are embedded in the layer of residual sandy soil 1-2 feet thick derived from the Hollis Quartzite." They felt that these gravels were transported by streams and represent an old erosion surface. They also felt that these gravels were older than those on the mountain slopes. We interpret these upland gravels to be residual and not remnants of transported material. We also consider the residual mountain soils to be younger than the soils developed on the many alluvial fans that are present along the slopes of the high ridges.
This soil (pedon 231-001) has a Bt horizon at least $170 \mathrm{~cm}$ thick, significantly thicker than the 64-cm-thick Bt in pedon 199-001 (classified as a Cecil) developed on schist. In comparison with the eluvial horizons of the Cecil (pedon 199-001), the eluvial part of the quartzite soil (pedon 231-001) is thick ( $A$ and $E$ horizons and upper part of the BE horizon). This greater thickness is probably due to the abundance of sand-sized quartz in the parent material, which produces a porous, grain-supported matrix in the upper part of the solum. The Cecil soil (199-001), which developed in schistose parent material, contains a smaller percentage of chemically resistant quartz sand.

There is evidence within the quartzite soil (pedon 231-001) that the quartz sand is being reduced in grain size by both mechanical and chemical processes. Such grainsize reduction has been documented for Piedmont soils by Pavich and others (1989). Evidence for quartz grain-size diminution by physical breakdown includes (1) a quartz silt maximum both above and below the clay maximum, (2) concurrence of the coarse silt minimum with the clay maximum, and (3) the high ratio of fine to coarse silt throughout the pedon. The origin of the silt appears to be in place rather than from an external (for example, aeolian or slopewash) source.

Figure $8 B$ shows the $X$-ray diffraction results from pedon $231-001$. The clay-rich lower part of the pedon is dominantly kaolinite having small percentages of $14.7-\AA$ hydroxy-interlayered vermiculite and $4.85-\AA$ gibbsite. The percentages of the latter two minerals increase as the 


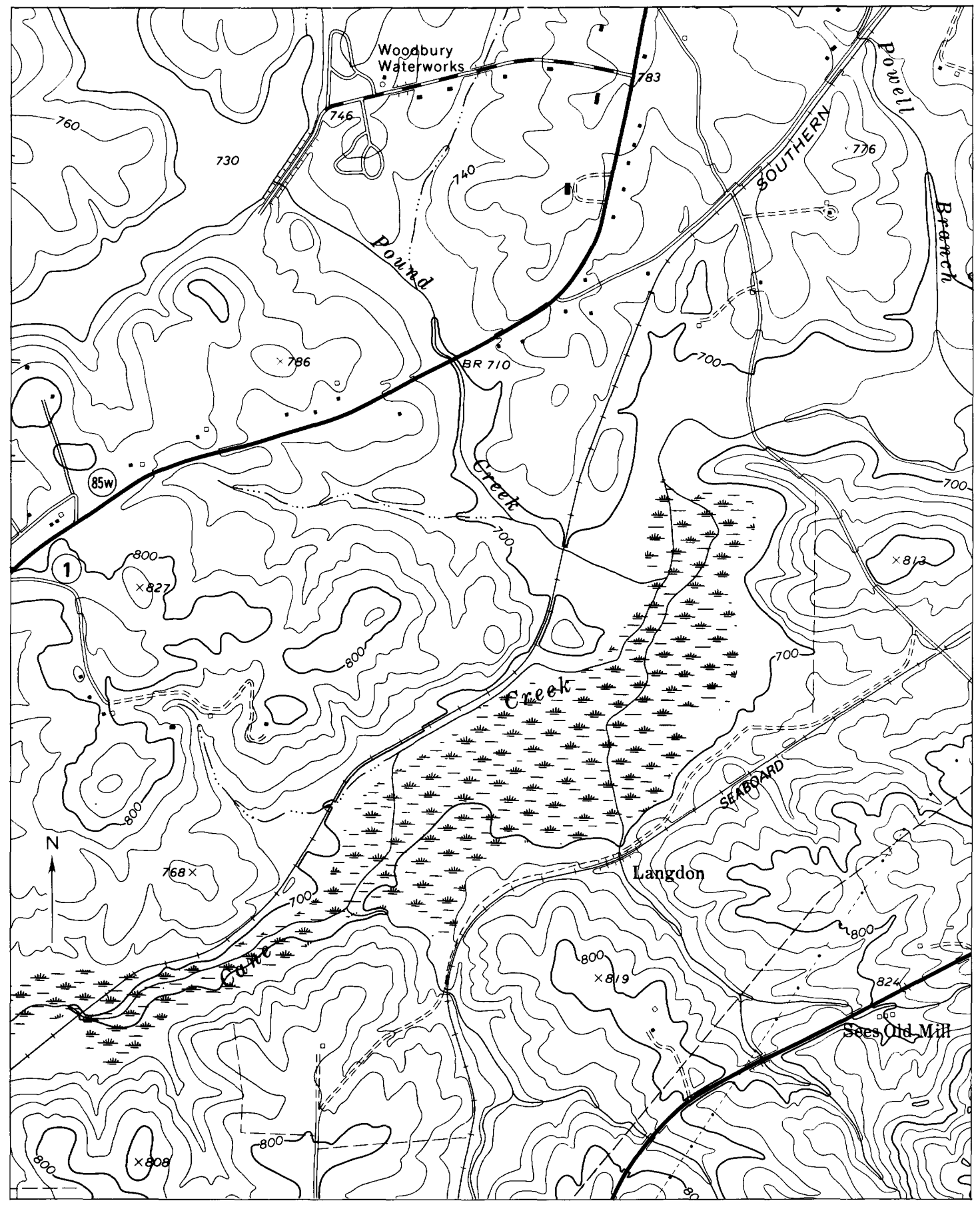

L KLOMETER

Figure $6 D$. Soil and weathering profile sample sites. Location map is part of a $7.5-\mathrm{min}(1: 24,000 \mathrm{scale})$ Georgia quadrangle and has a 20 -ft contour interval. Site numbers are the same as those given in figure $1 B$. Site 1 , Woodbury quadrangle.

percentages of kaolinite decrease upward. In contrast to the schistose soil (pedon 199-001), quartz is also present in the clay fraction of pedon $231-001$, particularly above the $\mathrm{Bt} 2$ (fig. $8 B$ ). This trend is the same as the one seen in Virginia and South Carolina Atlantic Coastal Plain soils (Markewich and others, 1986, 1987).

The major chemical change between the $\mathrm{BE}$ and $\mathrm{Bt}$ horizons is the significant decrease in the percentage of 


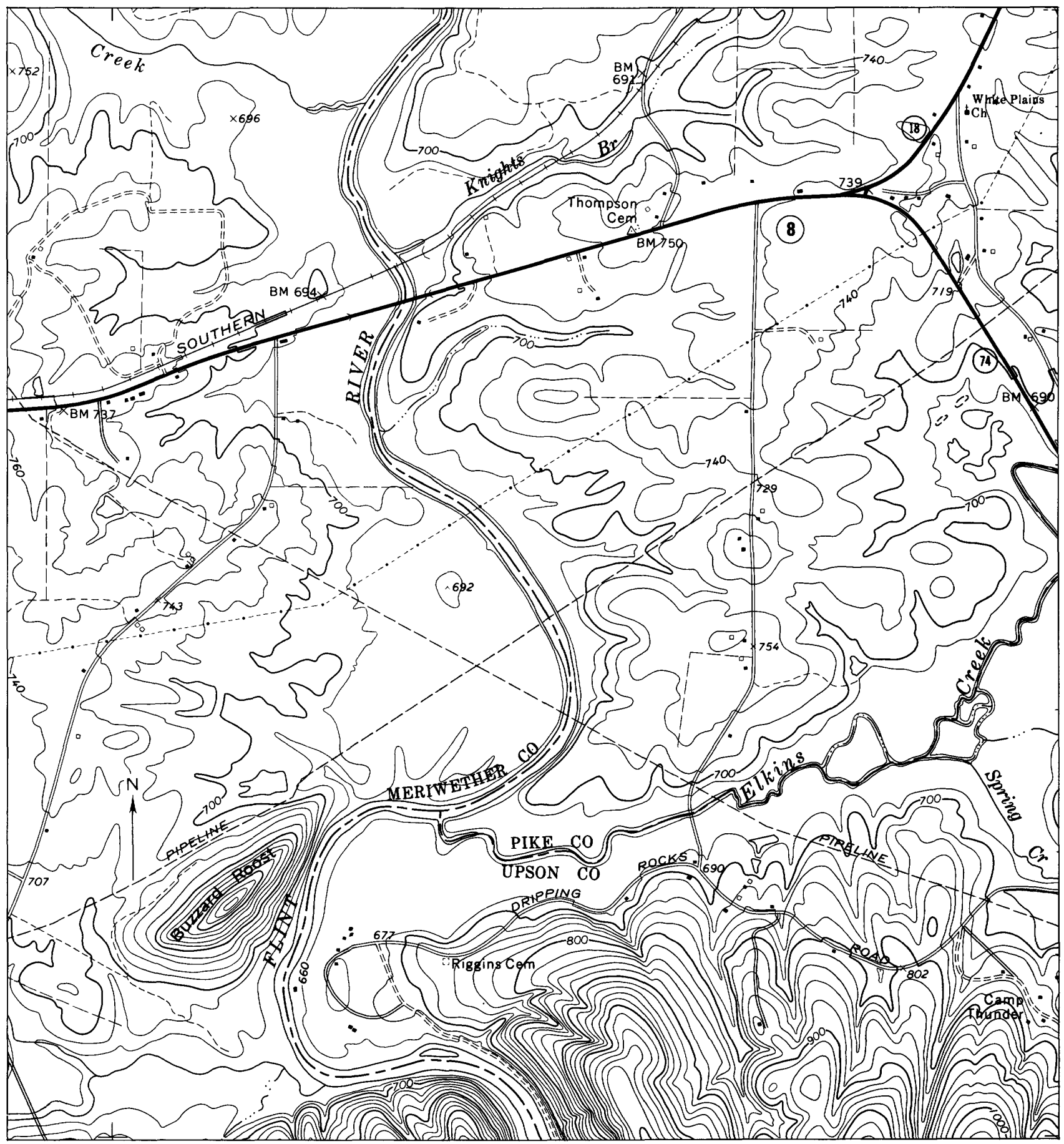

0

1 KILOMETER

Figure 6E. Soil and weathering profile sample sites. Location map is part of a 7.5-min (1:24,000 scale) Georgia quadrangle and has a 20 -ft contour interval. Site numbers are the same as those given in figure $1 B$. Site 8 , Woodbury quadrangle.

$\mathrm{SiO}_{2}$ relative to $\mathrm{Al}_{2} \mathrm{O}_{3}$ and $\mathrm{Fe}_{2} \mathrm{O}_{3}$ (table $7 D$ ). This decrease can be explained in part by translocation of aluminous kaolinite and ferric oxyhydroxides from the $\mathrm{E}$ horizon to the $\mathrm{Bt}$ horizon. The $\mathrm{A}, \mathrm{E}$, and $\mathrm{BE}$ horizons, however, are only $51 \mathrm{~cm}$ thick in comparison with the more than $160-\mathrm{cm}-$ thick Bt. Allowing for ongoing erosion of the A horizon, the mass balance between the illuvial and eluvial clay does not support a simple translocation model. It is more likely, as Pavich (1986) suggested, that dissolution of quartz, particularly clay-sized quartz, accounts for an absolute 


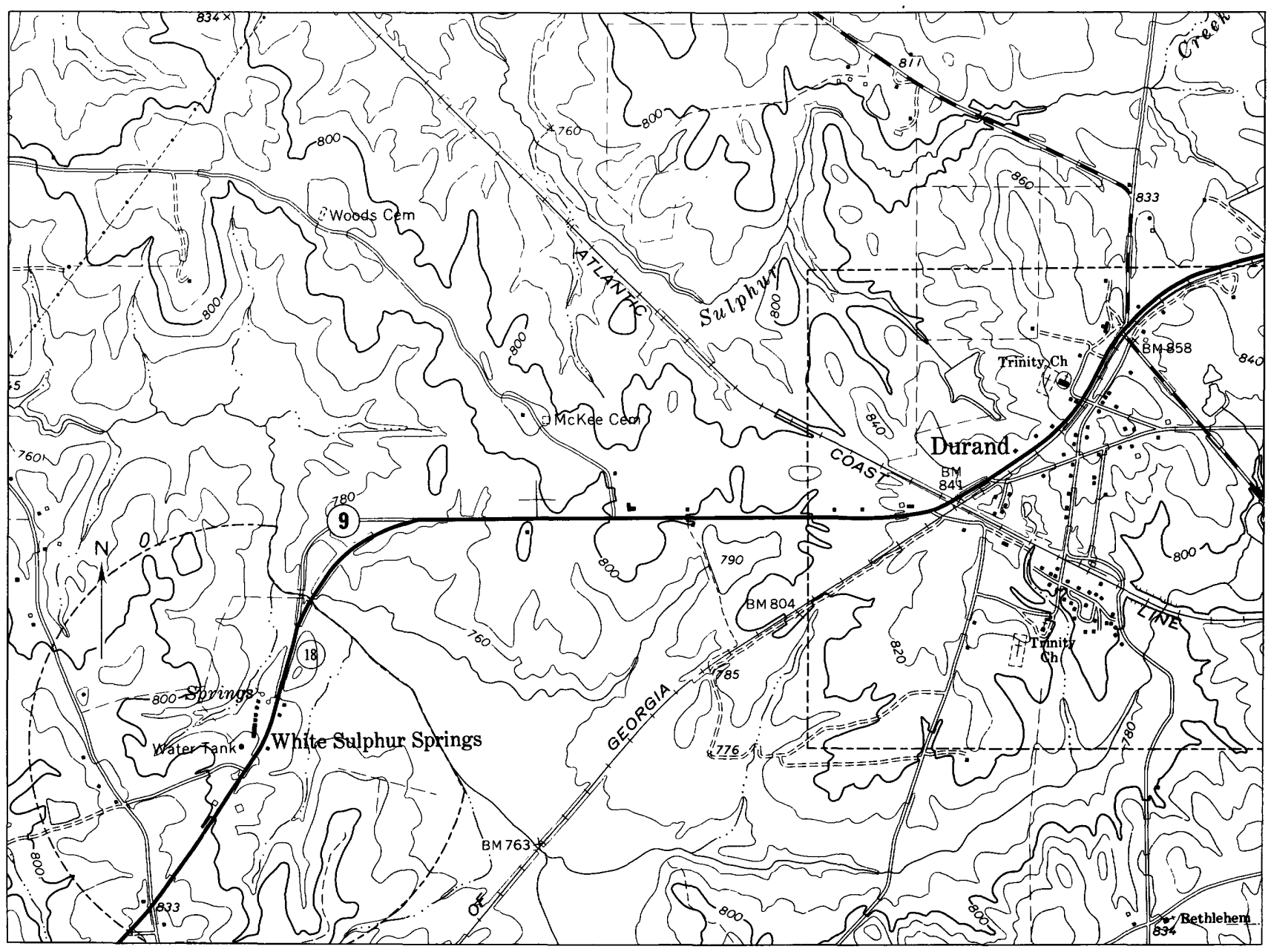

0

1 KILOMETER

Figure 6F. Soil and weathering profile sample sites. Location map is part of a 7.5-min (1:24,000 scale) Georgia quadrangle and has a $20-\mathrm{ft}$ contour interval. Site numbers are the same as those given in figure $1 B$. Site 9 , Durand quadrangle. Site 12 is shown in figure 14.

$\mathrm{SiO}_{2}$ depletion and relative $\mathrm{Al}_{2} \mathrm{O}_{3}$ and $\mathrm{Fe}_{2} \mathrm{O}_{3}$ enrichments in the $\mathrm{Bt}$ horizon. As silica is lost, $\mathrm{Al}_{2} \mathrm{O}_{3}$ and $\mathrm{Fe}_{2} \mathrm{O}_{3}$ should increase in a constant ratio. This suggestion is consistent with the fairly constant ratio of 3.6 for $\mathrm{Al}_{2} \mathrm{O}_{3} / \mathrm{Fe}_{2} \mathrm{O}_{3}$ in the $\mathrm{Bt}$ horizon. Furthermore, the ratio of 3.6 is significantly less than the ratio of 9.7 in the BE. If translocation of clay-sized material from the $\mathrm{BE}$ into a grain-supported quartz sand were the only mechanism responsible for the $\mathrm{Bt}$, then the $\mathrm{Al}_{2} \mathrm{O}_{3} / \mathrm{Fe}_{2} \mathrm{O}_{3}$ ratio would be expected to stay constant rather than decrease downward.

\section{Pedon 231-003: Colluvium over Quartzite}

The site of pedon 231-003 is near the top of Indian Grave Mountain, about $100 \mathrm{ft}$ higher than pedon 231-001. This soil has developed in colluvium overlying weathered Hollis Quartzite and is very different from the quartzite residual soil, having an $\mathrm{A} / \mathrm{C}$ profile only $71 \mathrm{~cm}$ thick (fig.
7C). This pedon does not have a Bt horizon (the clay maximum occurs in the C3) (see table $8 B$ ), and the dominant color is yellow-brown 10YR overlying a red 2.5YR, well-oxidized saprolite $C$ horizon. The residual soil (pedon 231-001) has a 169-cm-thick Bt horizon and color (hue) ranging from $10 \mathrm{YR}$ to $2.5 \mathrm{YR}$.

The dominant textural characteristics of pedon 231-003 are its high sand content, its low clay content, and its relatively low and constant ratio of fine to coarse silt (about 2:1 above the $\mathrm{C} 1$ horizon, in comparison with a ratio as high as 4:1 in the Bt2 horizon of pedon 231-001). The coarser texture of the colluvium may be due to winnowing of fine silt and clay during transport and deposition of the colluvium.

X-ray diffraction patterns for pedon $231-003$ are not shown. Kaolinite is the dominant clay mineral in the soil and in the underlying saprolite. Gibbsite is next in abundance. The soil contains relatively little 

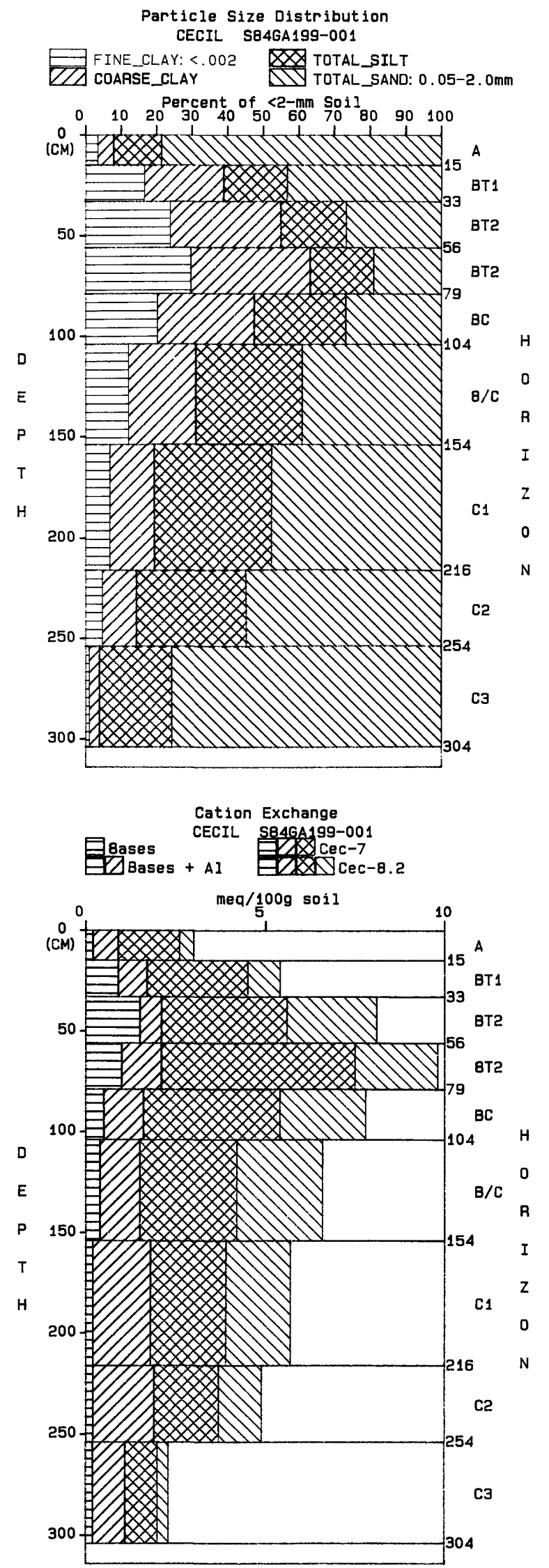

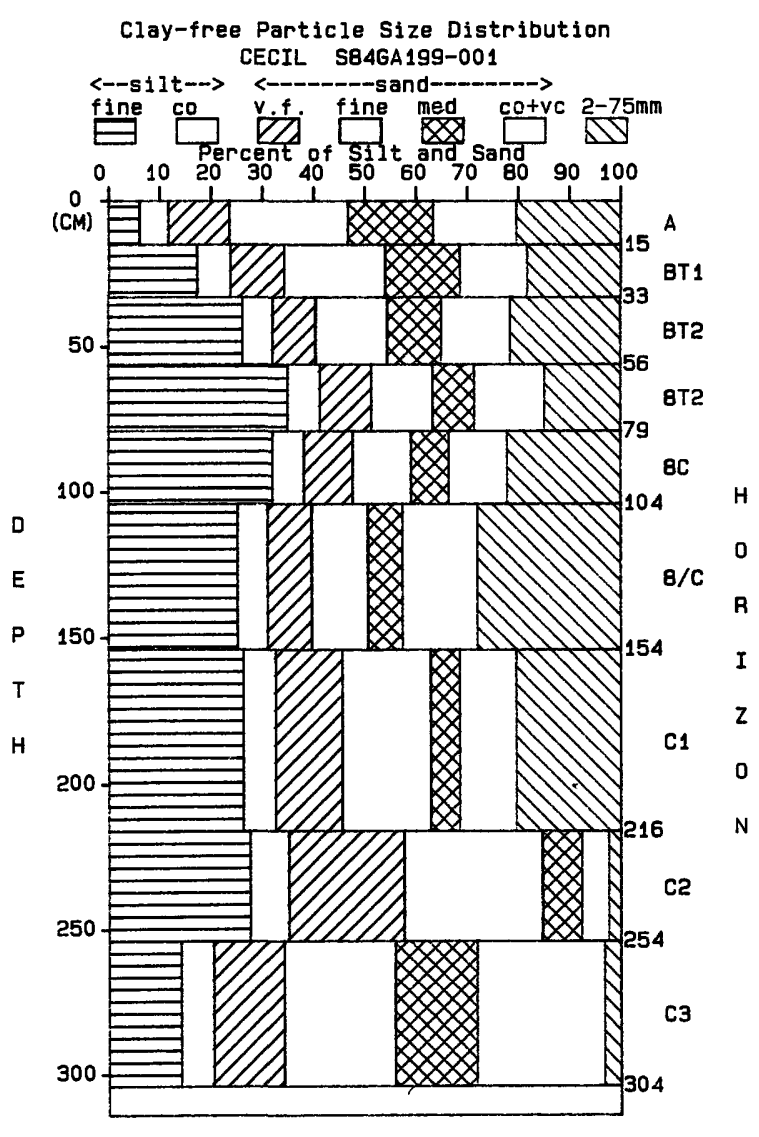

Soil Water, Pores and Solida CECIL SB4GA199-001


Figure 7A. Summary plots of soil data for pedon S84GA-199-001. 

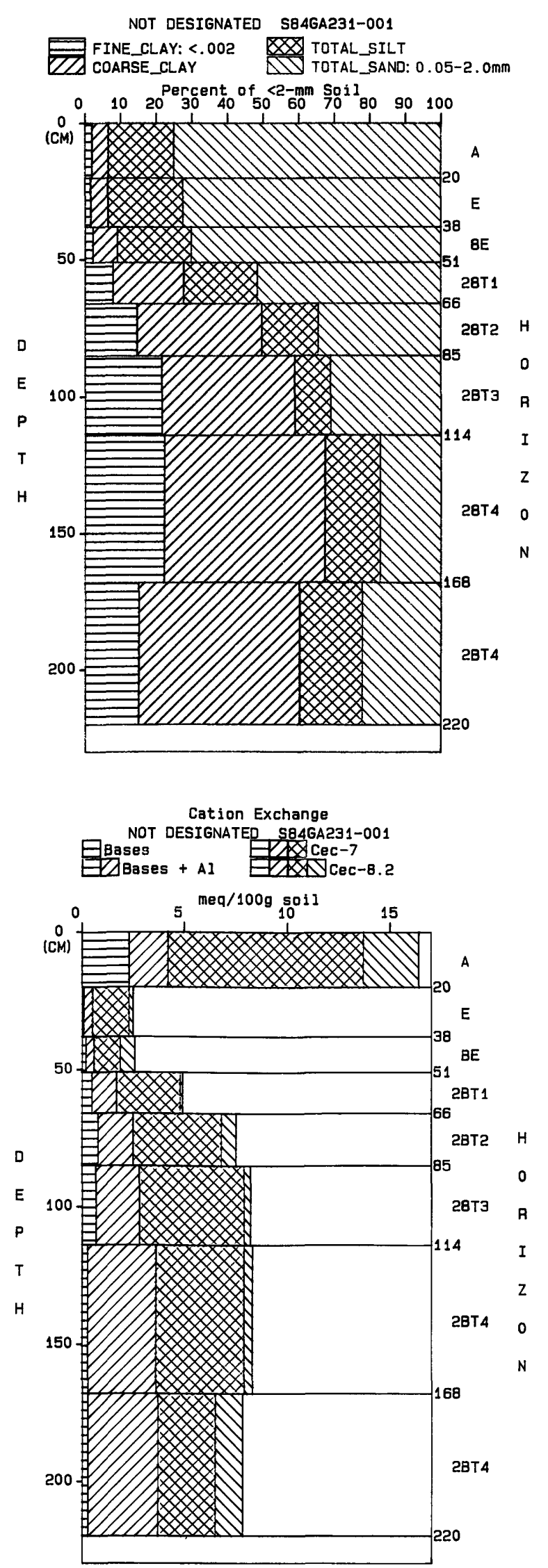

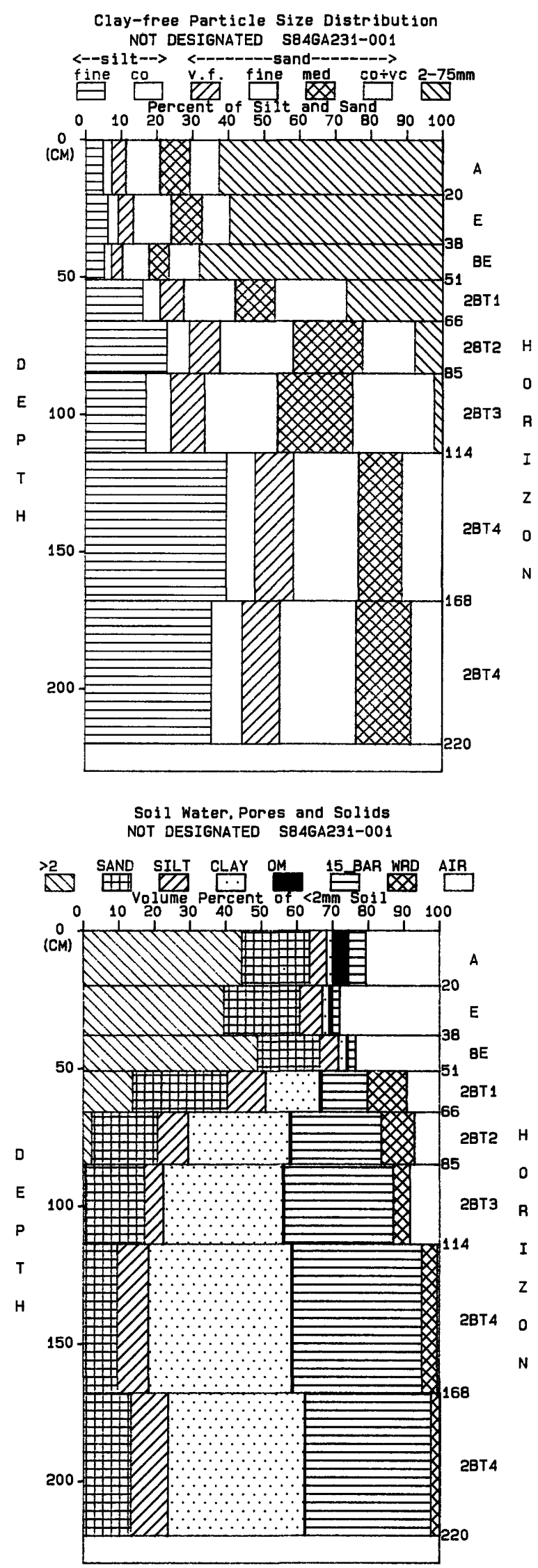

Figure $7 \boldsymbol{B}$. Summary plots of soil data for pedon S84GA-231-001. 

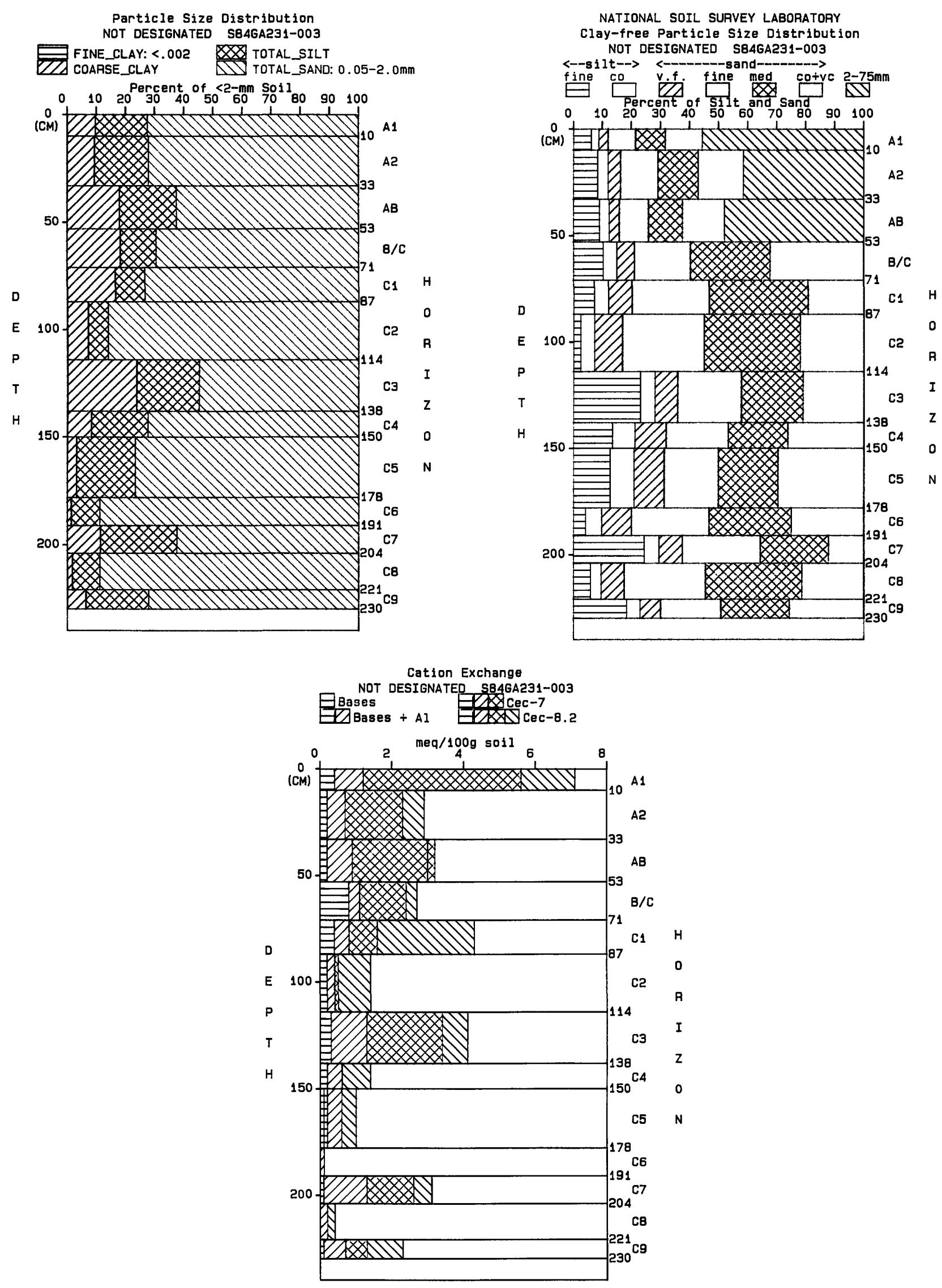

Figure 7 C. Summary plots of soil data for pedon S84GA-231-003. 

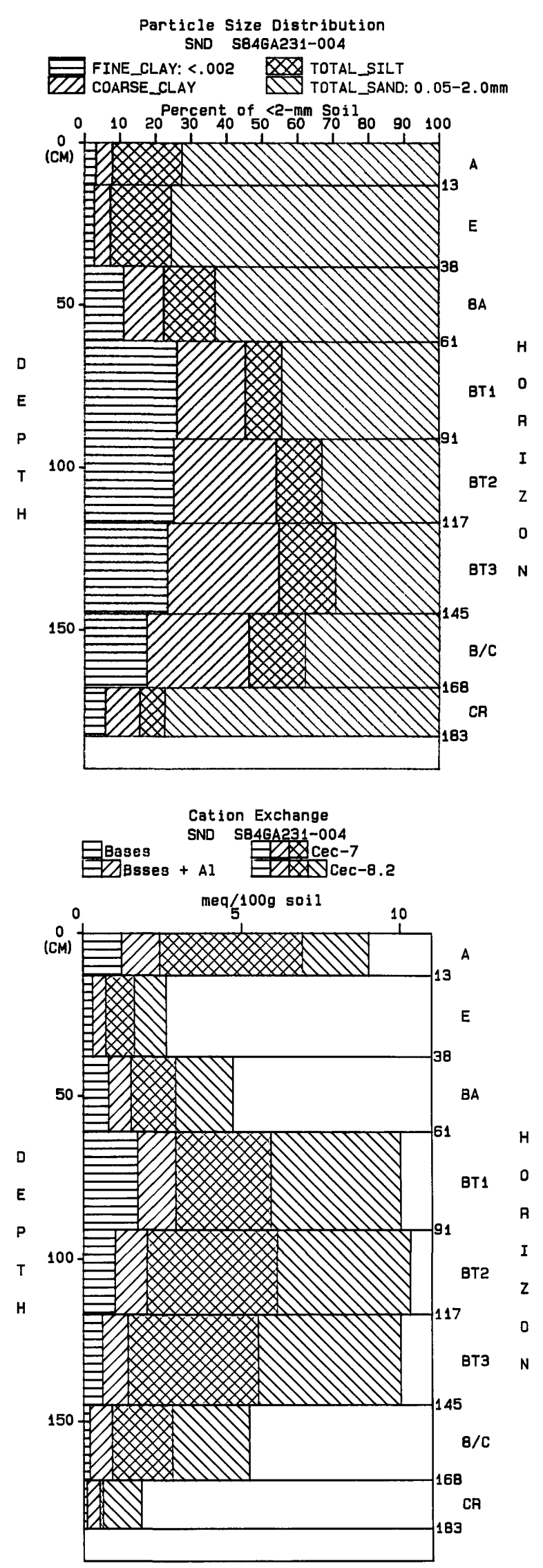

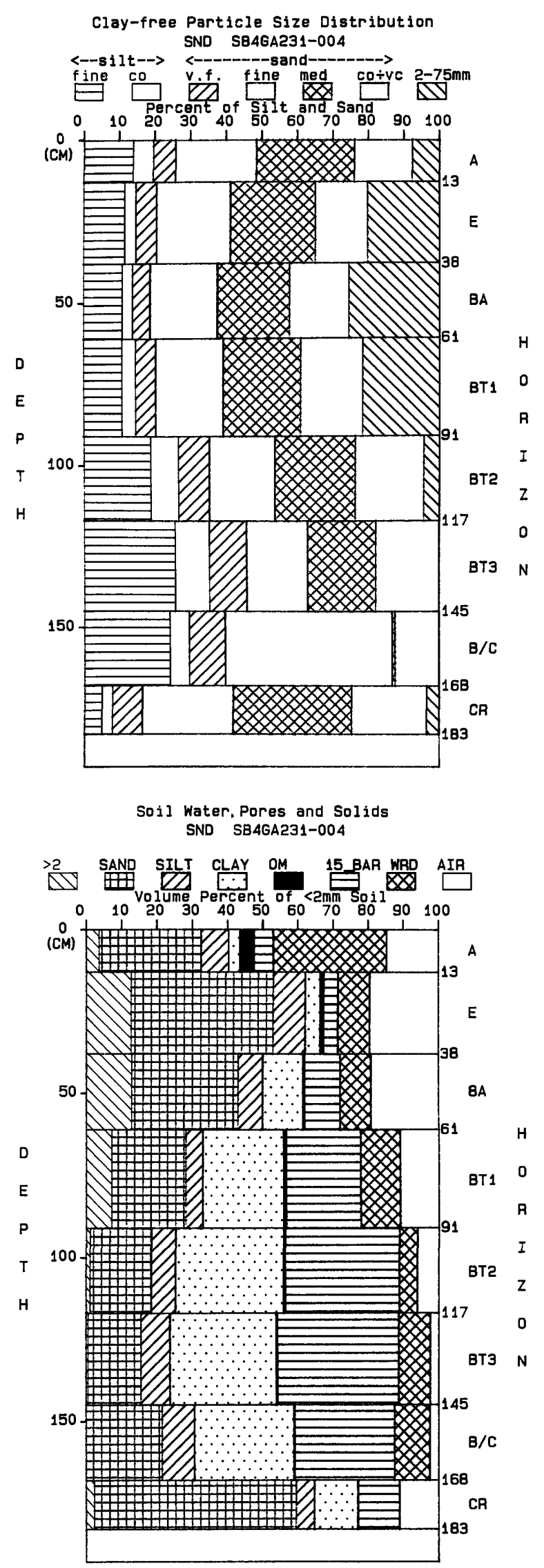

Figure $7 D$. Summary plots of soil data for pedon S84GA-231-004. 

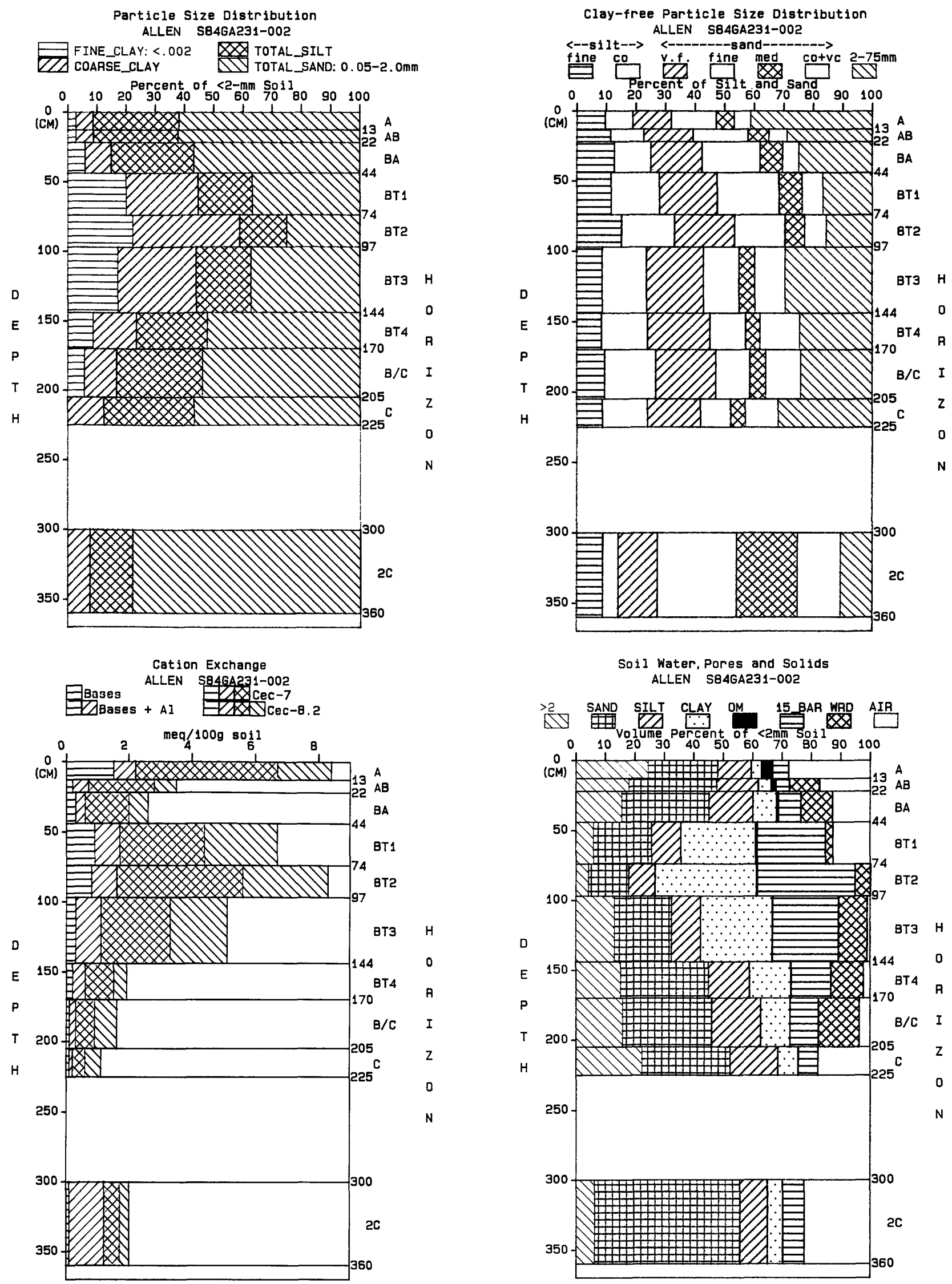

Figure $7 E$. Summary plots of soil data for pedon S84GA-231-002. 

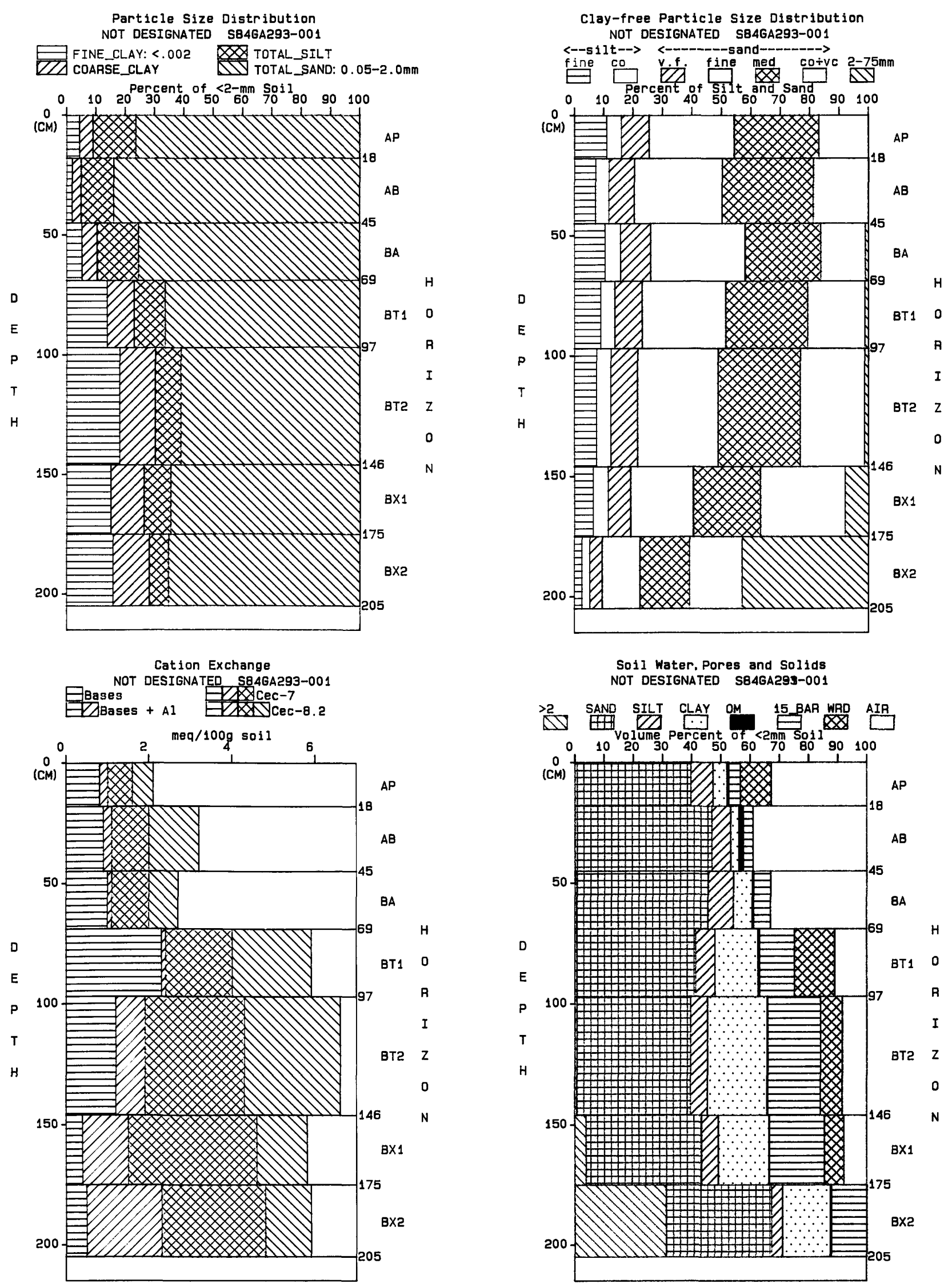

Figure 7F. Summary plots of soil data for pedon S84GA-293-001. 

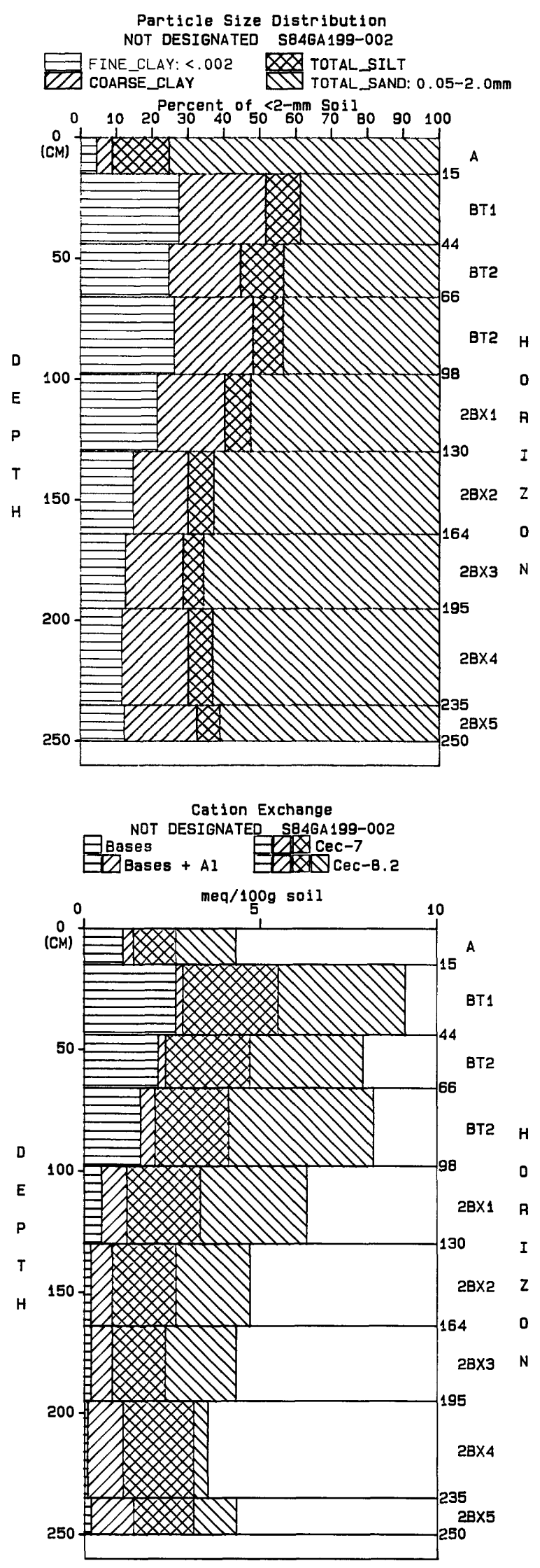

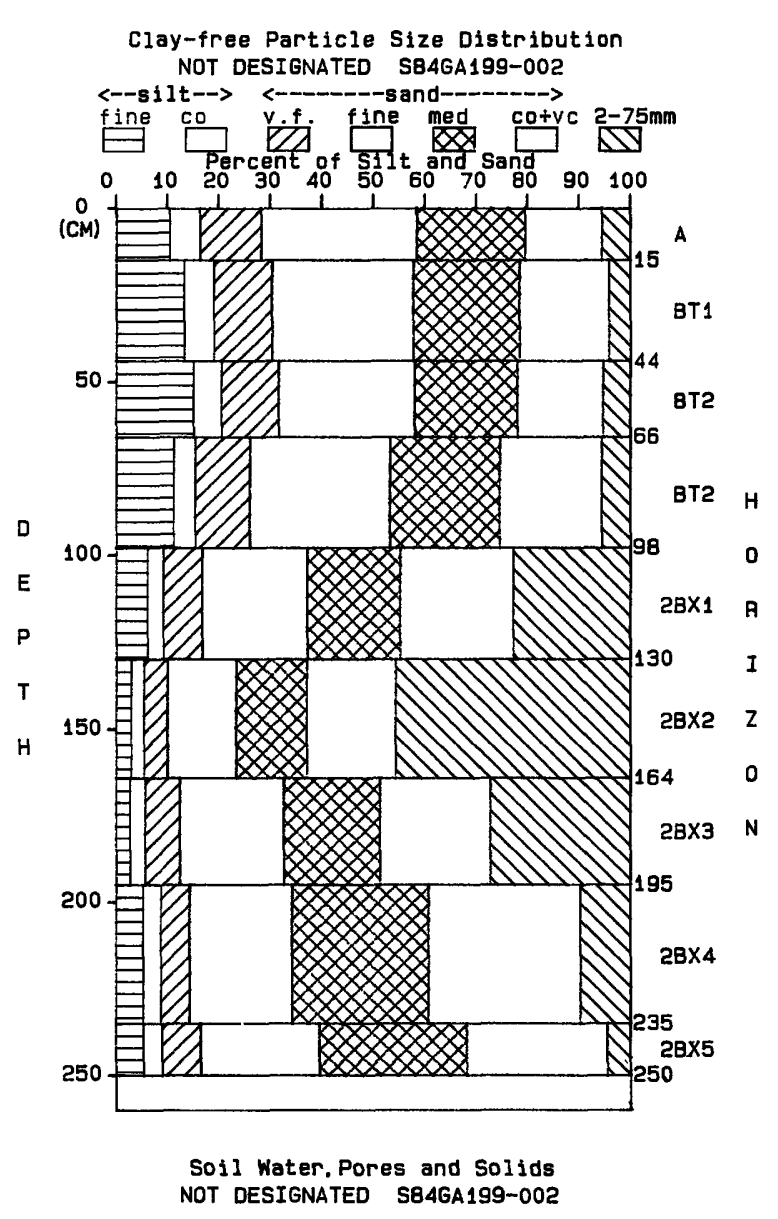

$>2$ SAND SILT CLAY OM

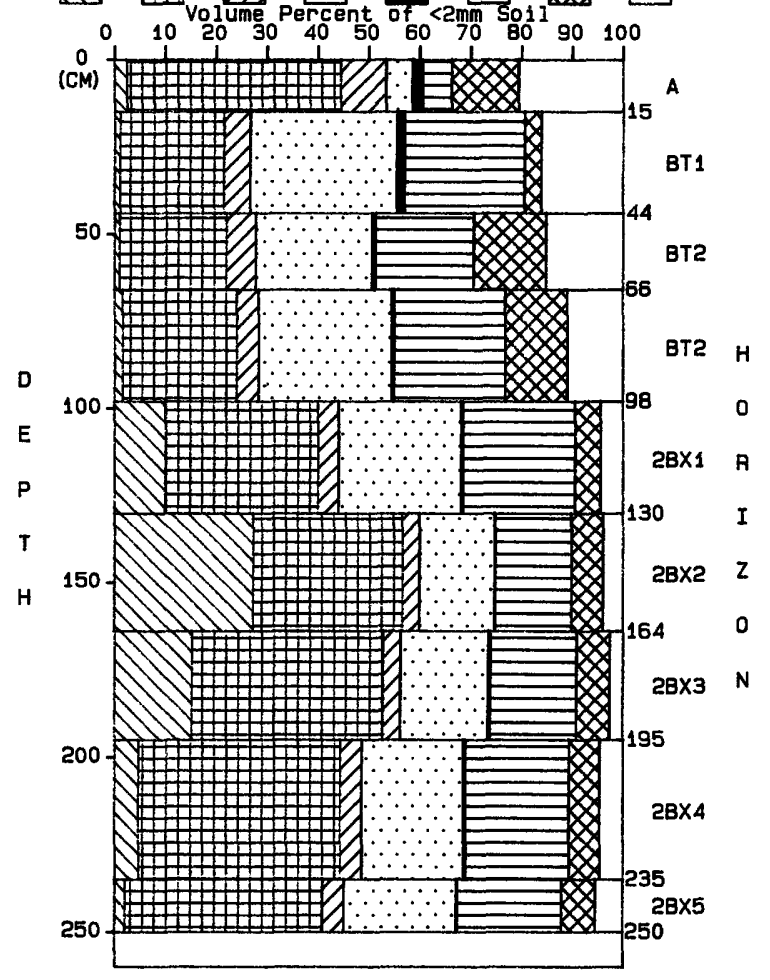

Figure 7G. Summary plots of soil data for pedon S84GA-199-002. 

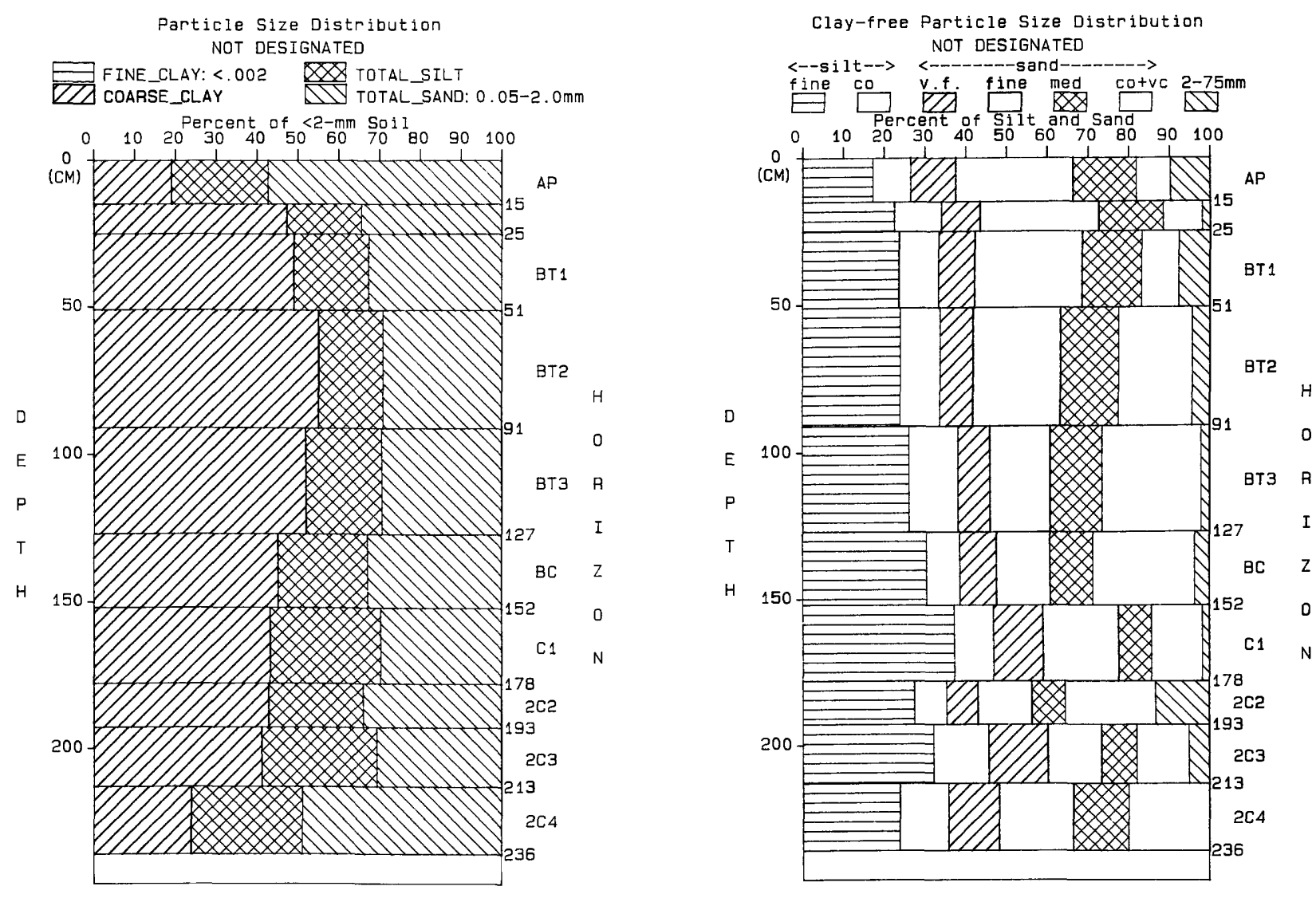

Figure $7 \boldsymbol{H}$. Summary plots of soil data for and unnumbered pedon in the Flint River terrace.

hydroxy-interlayered vermiculite (fig. $8 \mathrm{C}$ ) and more gibbsite, relative to kaolinite and vermiculite, than the residual quartzite pedon (231-001) (fig. 8B). The contrast in clay mineralogy between pedons $231-001$ and $231-003$ is due to better drainage in the colluvial pedon $(231-003)$, which would facilitate the removal of silica from kaolinite and (or) mica and the formation of gibbsite.

\section{Pedon 231-004: Quartzite Residual Soil}

The last of the "in place" mountain sites is represented by pedon $231-004$ (fig. $7 D$ ). This pedon is similar to pedon 231-001 (fig. 7B). It exhibits a well-developed Bt horizon and a thick solum. Clay and silt combined are more abundant than sand in the Bt horizon, and the ratio of fine to coarse silt is close to $4: 1$ in the upper horizons. As in pedon 231-001, there is a silt maximum both above and below the clay maximum. The ratio of fine to coarse silt is lowest in the Bt2 horizon, and the ratio of fine to coarse silt is highest in the upper $B$ and upper $C$ horizons.

These changes in ratio and weight percent are taken as evidence of the active breakdown of quartz sand to fine silt in the $C$ and upper $B$ horizons and of dissolution of silt in the Bt horizon. The thickness of the A plus E horizons $(38 \mathrm{~cm})$ is not sufficient to provide all the clay in the 84-cm-thick Bt horizon by translocation. It is much more likely that the clay maximum in the $\mathrm{Bt}$ is due to physical breakdown and chemical dissolution of the sand- and siltsized fractions.

The clay-sized fraction of pedon 231-004 contains abundant kaolinite and gibbsite and moderate to small amounts of hydroxy-interlayered vermiculite. The chemistry of pedon 231-004 has not been determined.

\section{Pedon 231-002: Landslide Debris (Quartzite)}

Pedon 231-002 (site 5) is similar to the mountain soils (sites 2, 3, and 4) in that it has also developed from the Hollis Quartzite. It is dissimilar in that it has developed on a slide block of Hollis that became detached from Indian Grave Mountain and slid northward to its present position (fig. $6 B$ ). The internal structure of the slide block is chaotic.

Pedon 231-002 has a well-developed argillic horizon that is significantly thinner than the argillic horizons of the residual quartzite profiles (pedons $231-001$ and 231-004) but thicker than the argillic horizon of the colluvial soil pedon (pedon 231-003). Pedon 231-002 is similar to other residual soils because it has a silt maximum both above and below the clay maximum. The ratio of fine to coarse silt is 


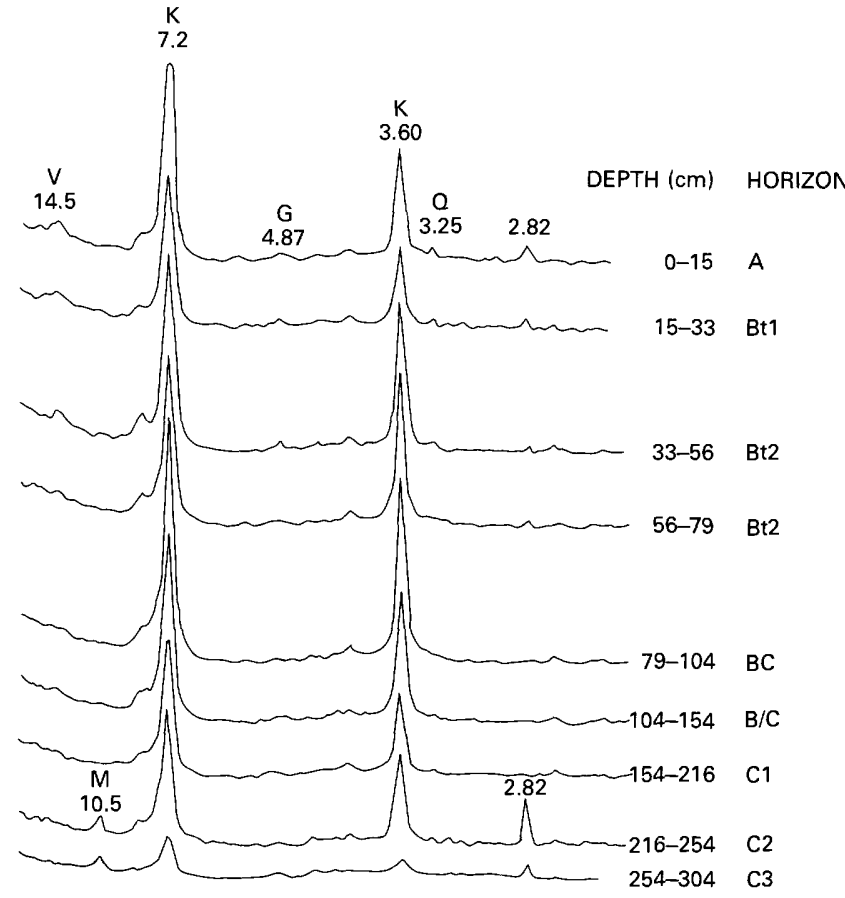

$\boldsymbol{A}$



less than it is in the residual quartzite pedons, possibly reflecting less time for breakdown of sand and coarse silt to fine silt and clay. The silt ratio difference may also reflect minor differences in parent material composition and (or) texture.

As is the case with the other pedons, the A-horizon thickness is insufficient to supply all the clay in the Bt horizon. The formation of clay in place from silt and sand

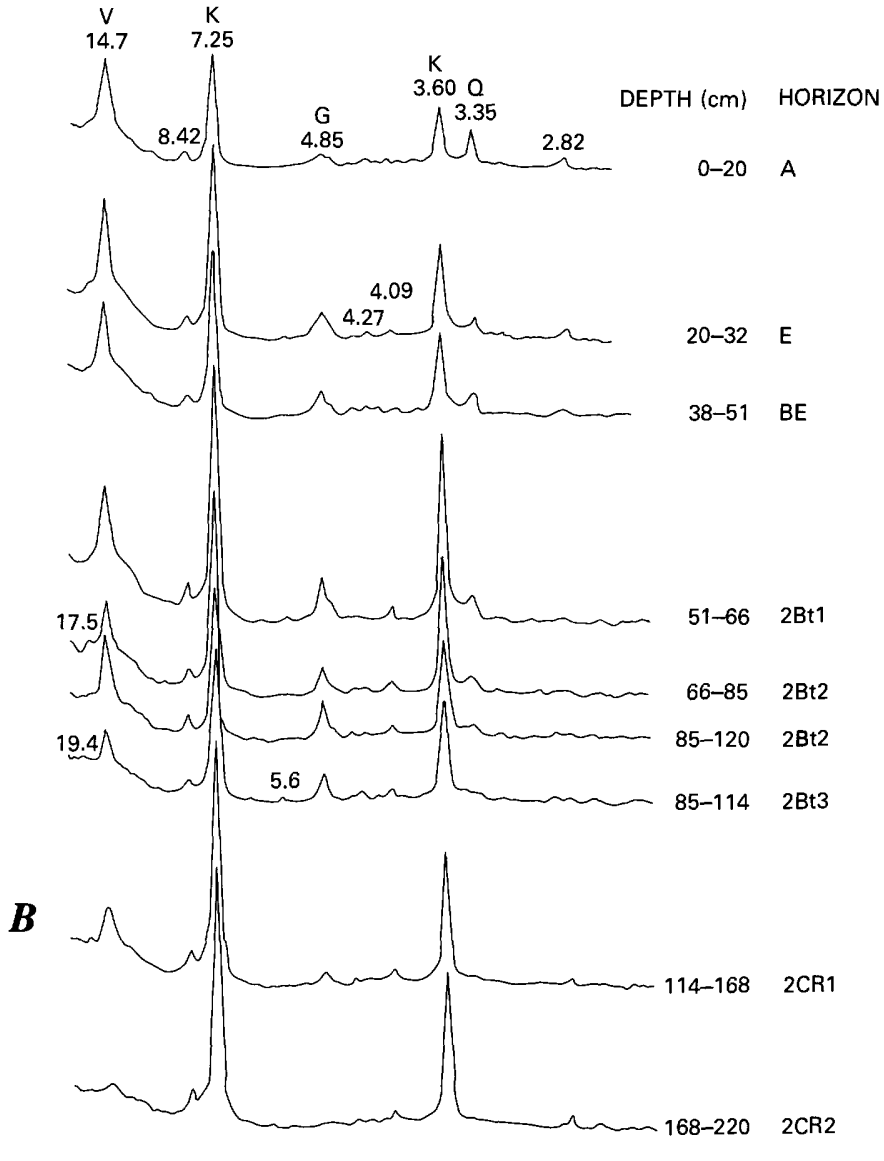

Figures $8 A, B, C$. X-ray diffraction patterns for untreated $<2-\mu \mathrm{m}$ fractions from selected horizons of pedons and from weathering profiles in the Pine Mountain area of west-central Georgia. Site locations are shown in figures $6 A-F$. Traces illustrated are of oriented, untreated clay. Peak spacings are in angstroms. Depths to middle of horizons and sample intervals are given in centimeters and inches, respectively. $\mathrm{V}$ is hydroxy-interlayered vermiculite, $M$ is mica, $K$ is kaolinite, $G$ is gibbsite, and $Q$ is quartz. $A$, Pedon S84GA-199-001 (Piedmont) (site 1); $B$, pedon S84GA-231-001 (mountain) (site 2); C, pedon S84GA-293-001 (fan) (site 6).

is the likely source of most of the clay in the Bt. This interpretation is supported by the commonly observed clayrich seams in the saprolite developed from Hollis Quartzite well below the Bt horizon. These red 10R seams are apparently zones of (1) intense in place weathering along zones of feldspar- or mica-rich parent material and (or) (2) downward and (or) horizontal translocation of clay-sized material in the seams. 

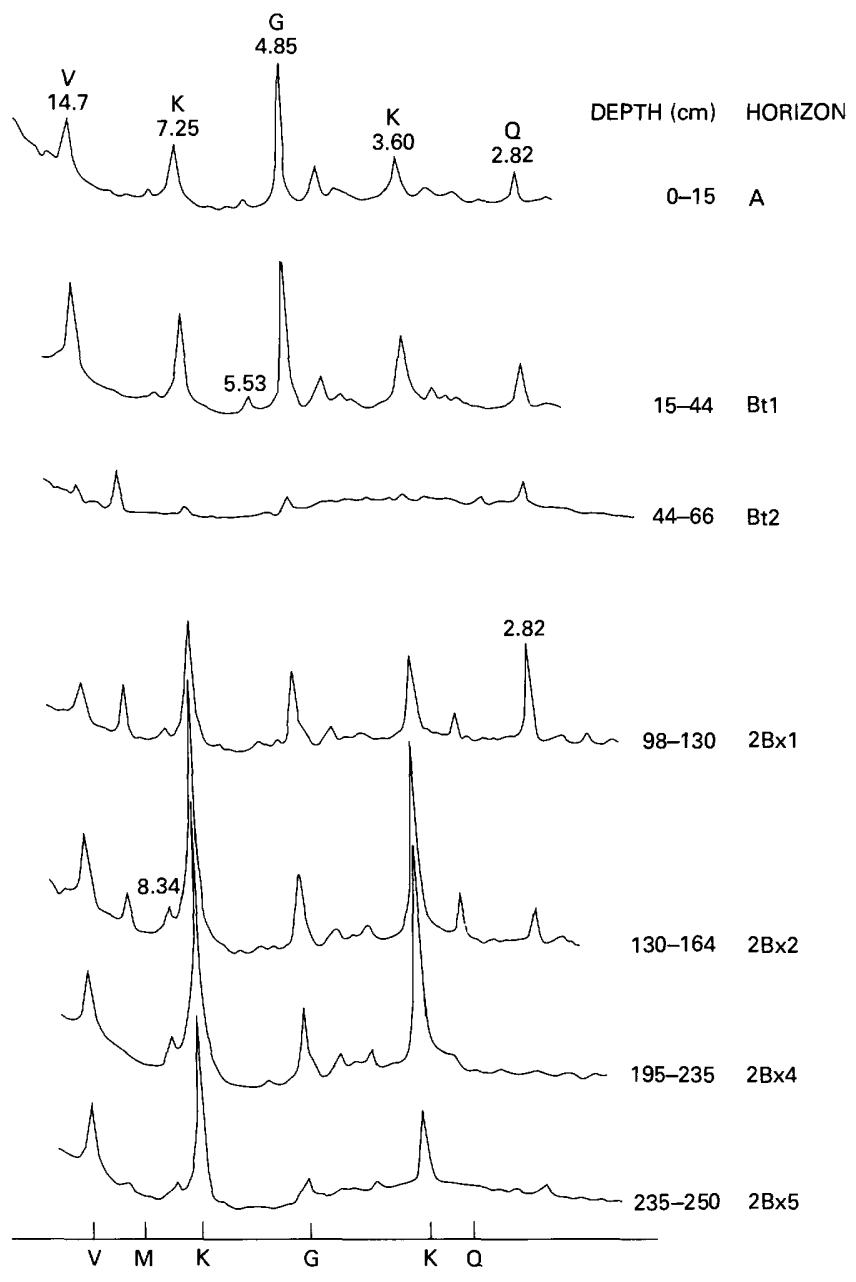

D

\section{Soil and Weathering Profiles in Alluvial Fan Parent Material}

Figure 10 shows aerial photographs of two alluvial fans in the eastern and central parts of the study area (Sunset Village and Warm Springs 7.5-min quadrangles). Alluvial fans such as these blanket the toe slopes of numerous quartzite ridges in the Pine Mountain area. We have identified fans on south-, north-, and east-facing slopes (figs. $6 A, 6 C$, and $11 A$, respectively). In the present topography, fan deposits form distinct hills at the base of the quartzite ridges. Local streams are incised into the fans. Commonly, stream beds are 20 to $40 \mathrm{ft}$ below the upper surfaces of the fans. Fan deposits consist of stacked sequences of fining-upward sand and gravel (subrounded to rounded medium sand to cobble gravel) (fig.11A). Many of

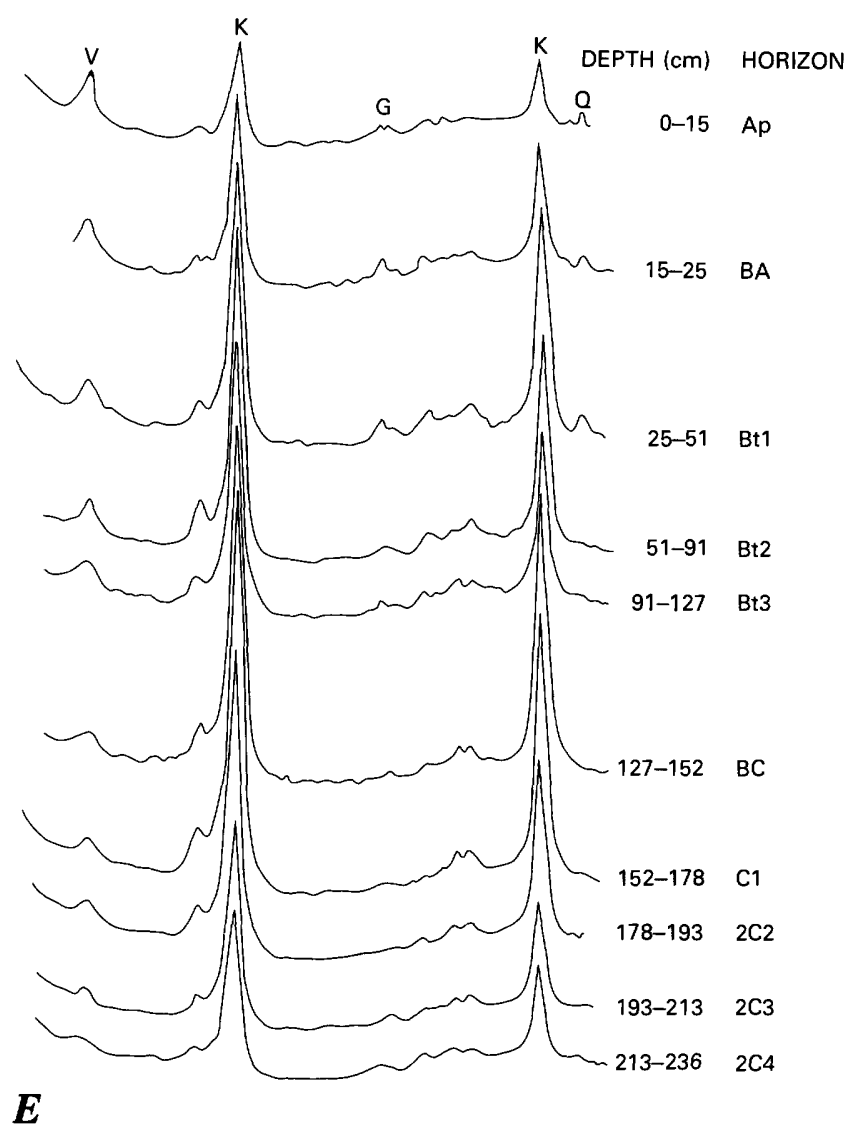

Figures $8 D, E$. X-ray diffraction patterns for untreated $<2-\mu \mathrm{m}$ fractions from selected horizons of pedons and from weathering profiles in the Pine Mountain area of west-central Georgia. Site locations are shown in figures $6 A-F$. Traces illustrated are of oriented, untreated clay. Peak spacings are in angstroms. Depths to middle of horizons and sample intervals are given in centimeters and inches, respectively. $\mathrm{V}$ is hydroxy-interlayered vermiculite, $\mathrm{K}$ is kaolinite, $\mathrm{G}$ is gibbsite, and $\mathrm{Q}$ is quartz. $D$, Pedon S84GA-199-002 (fan) (site 7); $E$, unnumbered pedon (Flint River terrace alluvium) (site 8).

the fan deposits have completely filled and topped paleovalleys and therefore are somewhat bowl shaped in cross section. Because of their geomorphic expression as erosional remnants, it is difficult to directly associate the fans with the present topography of the mountain slopes.

At least at one locality (the edge of the south-facing fan shown as $C$ in fig. 10A), the fans have 5- to 15 -ft-deep, 2- to 5-ft-wide cracks at the surface. The cracks are interpreted to be tensional, resulting from oversteepening of the slope by the adjacent deeply incised stream. These tension cracks are filled with a dark-red, clayey, masssive material rich in smectite (fig. $8 H$ ). The origin of the smectite is uncertain.

Weathering of the alluvial fan deposits, including oxidation, exceeds $50 \mathrm{ft}$ (as can be seen from exposures along county roads and railroads and from auger samples 

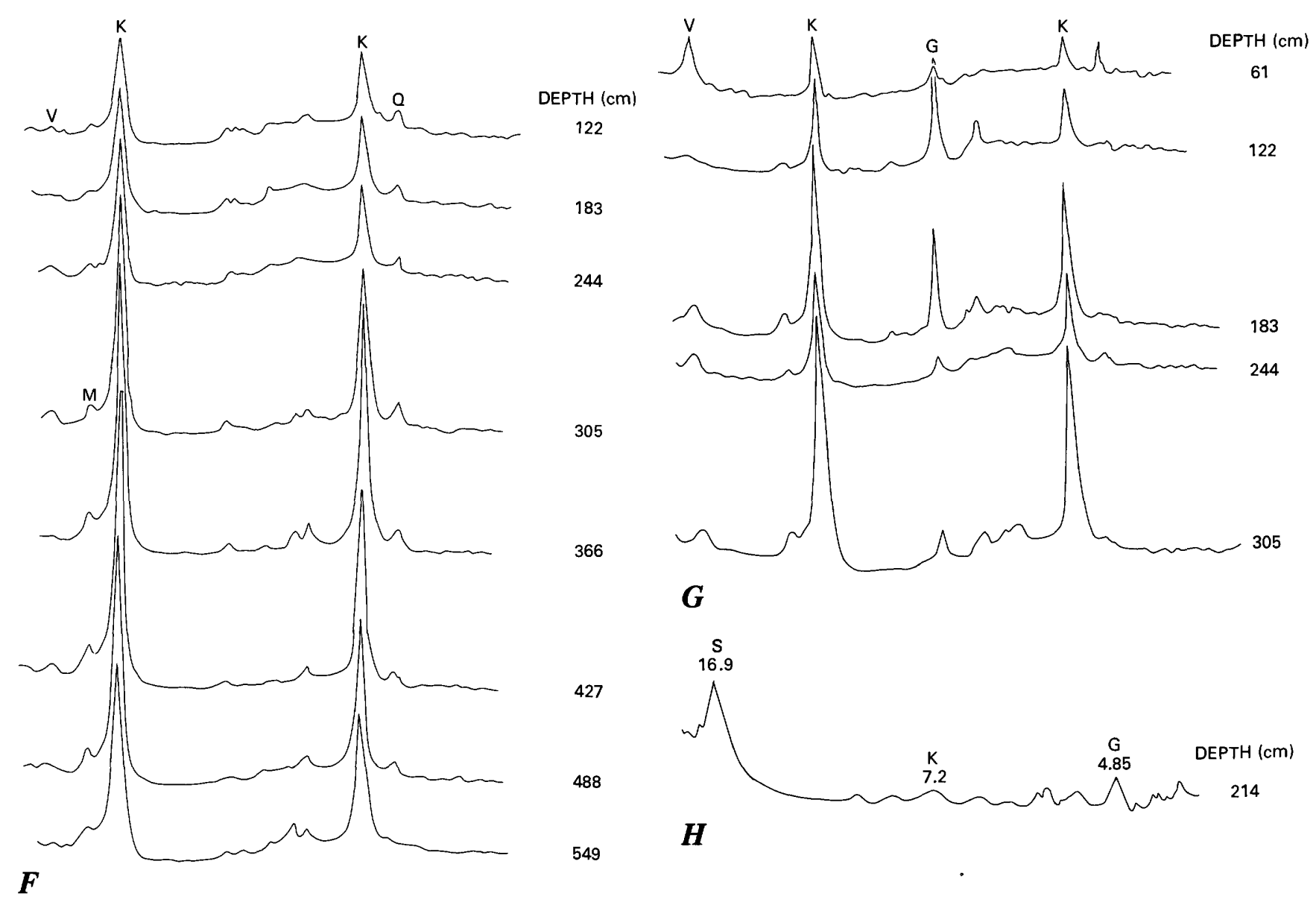

427
488

549

Figures $8 F, G, H$. X-ray diffraction patterns for untreated $<-2 \mu \mathrm{m}$ fractions from selected horizons of pedons and from weathering profiles in the Pine Mountain area of west-central Georgia. Site locations are shown in figures $6 A-F$. Traces illustrated are of oriented, untreated clay. Peak spacings are in angstroms. Depths to middle of horizons and sample intervals are given in centimeters and inches, respectively. $V$ is hydroxy-interlayered vermicu-

taken for this study). Locally, the depth of oxidation may be much deeper. The composition of alluvium is controlled by rock type in the source area.

These incised and dissected alluvial fans have no recognizable surface features (such as channels or levees), are deeply weathered and oxidized, and have thick soils containing fragic horizons. There is no evidence of fan formation in the modern landscape. For these reasons, we view the fans in the Pine Mountain area as no younger than early Pleistocene and probably Pliocene. Because the presence of alluvial fans in the Piedmont is uncommon, if not rare, we consider the fans to represent disequilibrium periods of rapid deposition. Although we believe that deposition of the fan material was in response to climatic events, we do not reject the possibility of seismic and (or) tectonic activity during or just before periods of fan formation. We discuss the relative ages of constructional and erosional landforms in "Age Estimates for Soils and Geomorphic Surfaces" (p. E41). We use the weathering and soil data from these fans in limiting the age(s) of physiographic features of the region.

Soils developed on alluvial fans in the Pine Mountain window are in excess of $9 \mathrm{ft}$ thick. Two sites having different aspects were selected for detailed characterization. Site S84GA-293-001 is on an east-facing, 3-percent planar slope, and site S84GA-199-002 is on a northfacing, 3-percent planar slope. Both sites are on dissected remnants of fan surfaces and are considered to be well 

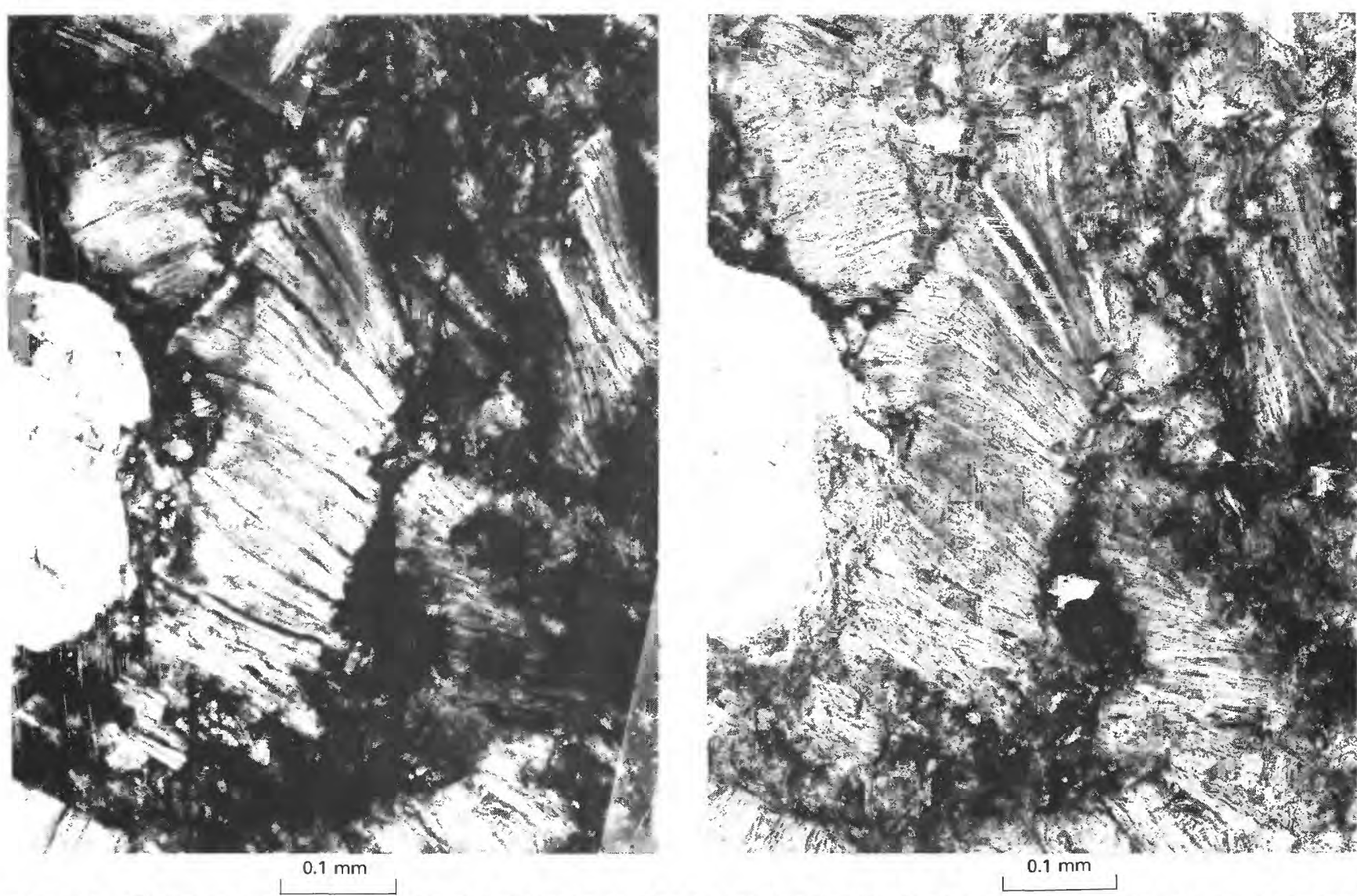

Figure 9. C2 horizon of pedon S84GA-199-001 (site 1). The soil at this locality has been described as a Cecil. Mica and kaolinitic pseudomorphs of mica form "books" that are recognizable in the weathered C horizon of this profile. Magnification $\times 150$. $A$, Crossed nicols; $B$, plane polarized.

drained. The dominant pedogenic features in both of these pedons are the fragic $\mathrm{Bx}$ horizons ${ }^{12}$ beneath the $\mathrm{Bt}$ horizons. The characteristics of each of the soils are discussed below.

Relative to the residual soil (Cecil, pedon 199-001) developed in foliated Piedmont rocks and to residual mountain soils developed in the Hollis Quarztite, pedon 293-001 has a thick $(69 \mathrm{~cm})$ epipedon split into $\mathrm{Ap}, \mathrm{AB}$, and $\mathrm{BA}$ horizons. The $\mathrm{AB}$ and $\mathrm{BA}$ have a silt-loam texture and weakly developed, subangular, blocky structure. Textural analysis shows that fine to medium sand is dominant in the epipedon. Total silt in pedon 293-001 reaches a maximum in the Ap horizon, whereas silt maxima are in the lower B and upper $\mathrm{C}$ horizons of residual soils. In the $\mathrm{Bt}$ horizon $(69-146 \mathrm{~cm})$, clay increases and silt decreases relative to clay and silt in the epipedon. The sand fraction also

${ }^{12}$ Fragic horizon or fragipan is defined as "a dense subsurface layer of soil whose hardness and relatively slow permeability to water are chiefly due to extreme compactness rather than to high clay content (as in clay pan) or cementation (as in hard pan). It appears indurated when dry, but shows a moderate to weak brittleness when moist. It contains much silt and sand, but little clay and organic matter" (Bates and Jackson, 1987, p. 257). decreases in the Bt horizon, but the coarse and very coarse sand fraction in the profile increases downward (particularly in the $\mathrm{Bx} 1$ at $146 \mathrm{~cm}$ and the $\mathrm{Bx} 2$ at $175 \mathrm{~cm}$ ) (see table $11 B$ ).

In the $\mathrm{Bx}$ horizons of pedon 293-001, the major change in texture from the $\mathrm{Bt}$ horizon is a decrease in total silt from the surface to $175 \mathrm{~cm}$-particularly the decrease in fine silt from the surface to $205 \mathrm{~cm}$. There is also an increase in the very coarse fraction, mainly of rock fragments. The decrease of fine silt from the $\mathrm{Bt}$ to the $\mathrm{Bx}$ horizons is seen on the plot of clay-free texture (fig. $7 F$ ). The decrease of fine silt coincides with changes in bulk density and water content.

Data in table $12 B$ show that the north-facing fan soil (pedon 199-002) contains more clay in its Bt horizon than the SSE.-facing fan soil (pedon 293-001). The Bt 2 horizon in pedon 199-002 is about the same thickness as the Bt2 horizon in pedon 293-001 but occurs higher in the profile. The combined thickness of the $\mathrm{Bx}$ horizons in pedon 199-002 is greater than that in pedon 293-001, and the uppermost $\mathrm{Bx}$ horizon is nearer to the ground surface. The weight percentages of clay, silt, and sand in the Bx horizons in the two pedons are similar. The textural profile of pedon 199-002 is shown in figure $7 G$. The main 


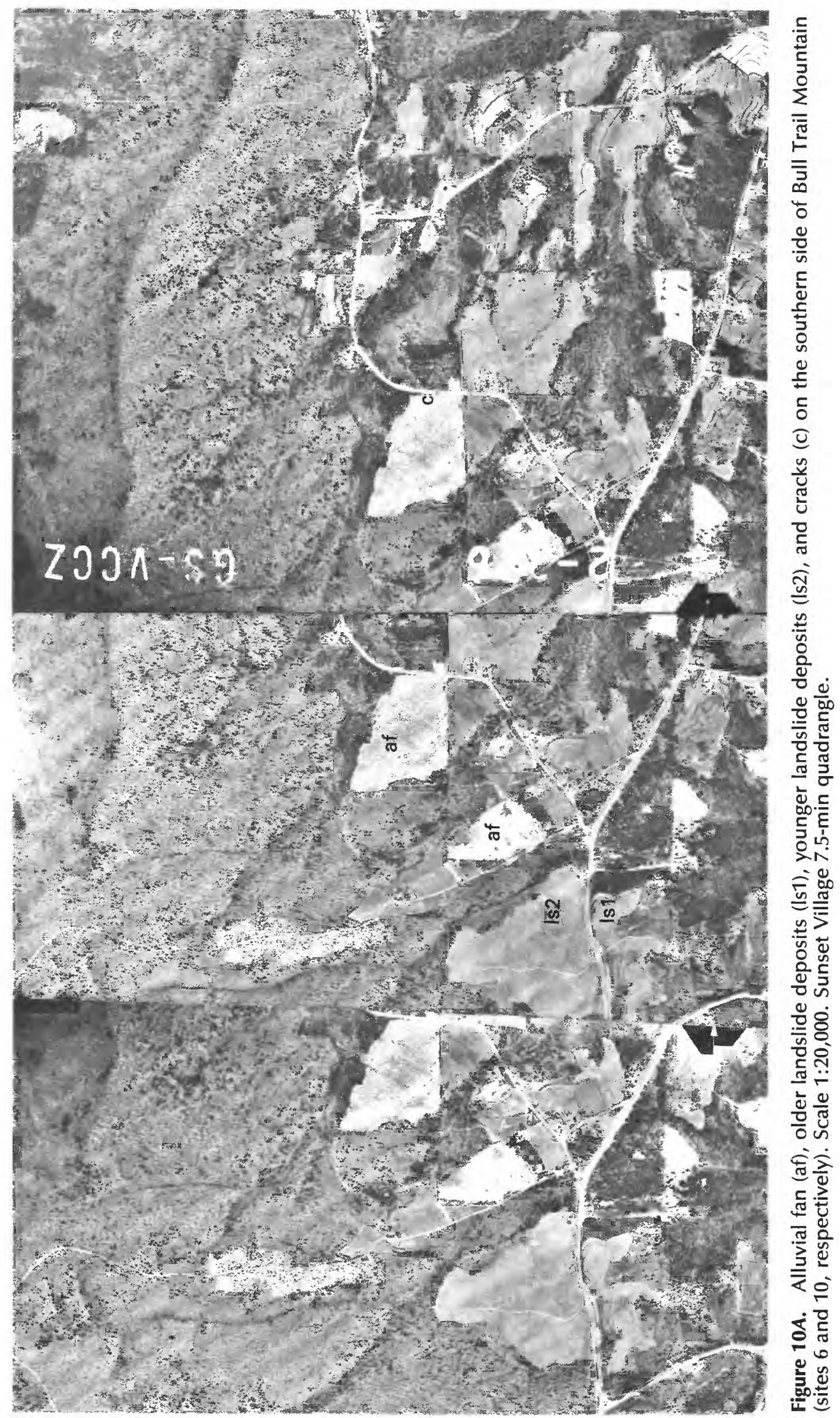




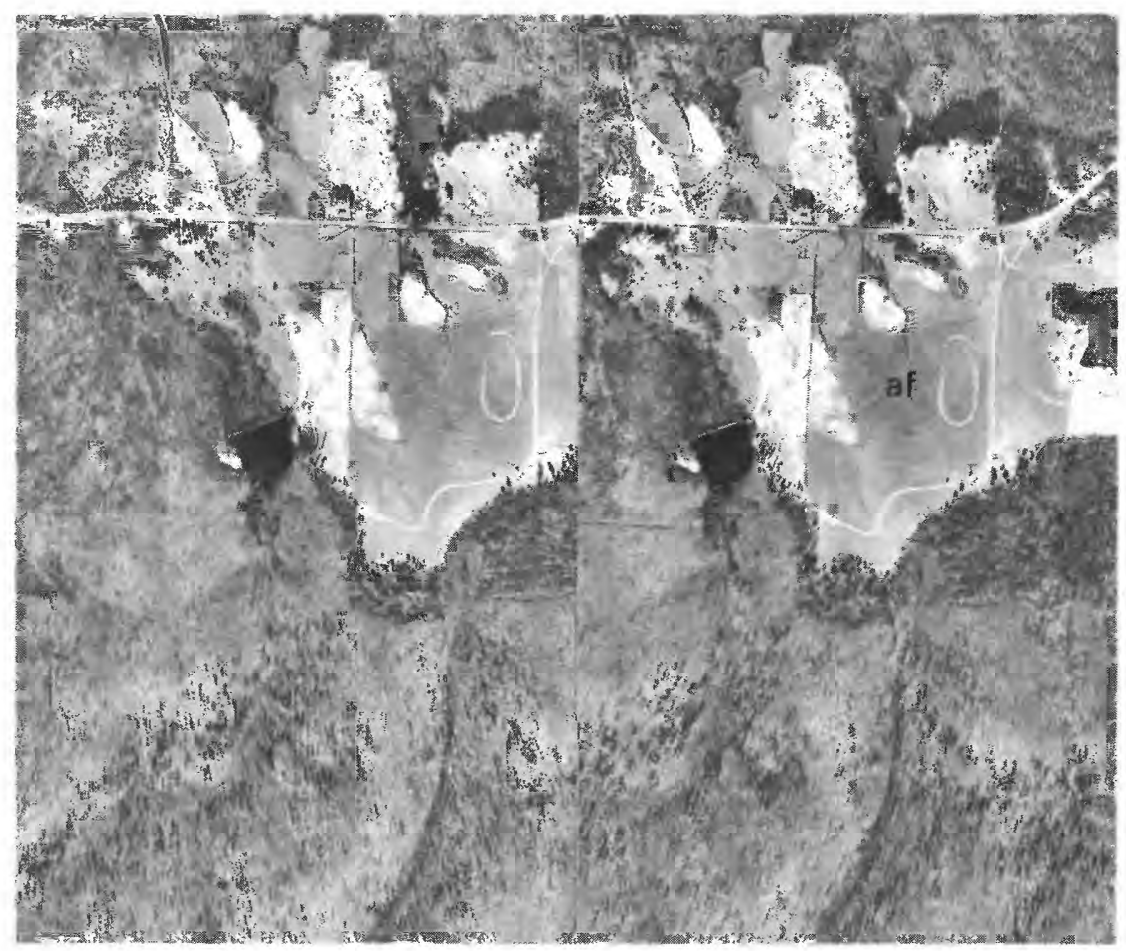

Figure 10B. Large alluvial fan (af) on the northern side of Pine Mountain just west of Warm Springs, Ga. (site 7). The cleared area north of the treeline outlines the fan. Scale 1:20,000. Warm Springs 7.5-min quadrangle.

differences in particle-size distribution between pedon 199-002 and pedon 293-001 are differences in clay content in the $\mathrm{Bt} 2$ horizons and the position of the $\mathrm{Bt} 2$ horizon in the pedons. A similar decrease of clay between the $\mathrm{Bt} 2$ and $\mathrm{Bx}$ horizons is seen in both profiles. Along with the clay decrease, the total silt (particularly fine silt) decreases between the $\mathrm{Bt} 2$ and $\mathrm{Bx}$ horizons. This decrease is seen clearly in the clay-free texture plot in figure $7 G$. This similarity suggests a depletion of fine silt during pedogenesis rather than control of the silt texture by the parent material. As it is in pedon 293-001, the fine silt in pedon 199-002 is preferentially depleted, and there is no evidence of an upward-fining parent material. We hypothesize that the fine silt has undergone preferential dissolution in the $\mathrm{Bx}$ horizon. Bulk density and water content provide evidence for unique packing and hydrologic properties of the $\mathrm{Bx}$. Bulk density in the Bt of both pedon 293-001 and pedon $199-002$ is 1.64 to $1.71 \mathrm{~g} / \mathrm{cm}^{3}$, typical of Bt horizons elsewhere in the Piedmont and Coastal Plain. The bulk density increases abruptly in the Bx2 of pedon 293-001 to $2.16 \mathrm{~g} / \mathrm{cm}^{3}$, an increase of nearly 30 percent relative to the $1.71 \mathrm{~g} / \mathrm{cm}^{3}$ of the $\mathrm{Bt} 2$. In the same interval, the $1 / 3-\mathrm{bar}$ water content decreases by about 60 percent, whereas the 15-bar water is relatively constant between the $\mathrm{Bt}$ and the $B \times 2$. These observations suggest that changes in the hydrologic property of the Bx horizon coincide with the loss of fine silt and changes in the soil fabric. The result is a density increase. We stress the fine silt depletion because it is not so striking in the mountain and Piedmont pedons.

The decrease in silt in the $\mathrm{Bx}$ horizon of pedon 199-002 is also coincident with an increase in bulk density from $1.3 \mathrm{~g} / \mathrm{cm}^{3}$ in the $\mathrm{Bt} 2$ to $1.8 \mathrm{~g} / \mathrm{cm}^{3}$ in the $2 \mathrm{Bx} 3$ horizon - an increase of nearly 40 percent. The increase in bulk density is correlative with a decrease in the $1 / 3-$ bar water content from 24.8 percent to 15.5 percent. Although the absolute bulk density and the $1 / 3$-bar water content are not the same as those in the Bx horizon of pedon 293-001, the textural, bulk density, and water content trends are the same from the Bt to the Bx horizons in both profiles, the suggestion being that the trends are due to pedogenic loss of fine silt and change in fabric rather than control by parent material characteristics.

The clay mineralogy of pedons developed in the alluvial fan material, shown in figures $8 C$ and $D$, is significantly different from that of pedons developed in residual soils. The most striking difference is in the percentages of 14.7- $\AA$ vermiculite and $4.87-\AA$ gibbsite. These phases are associated, and high contents of gibbsite and vermiculite indicate that alteration of the parent material took place under well-drained conditions (Markewich and others, 1986). Unlike pedons on the Coastal Plain in Virginia (Markewich and others, 1987) and North Carolina (Soller, 1988), there is no tendency toward increasing kaolinite and decreasing vermiculite and gibbsite as a function of 


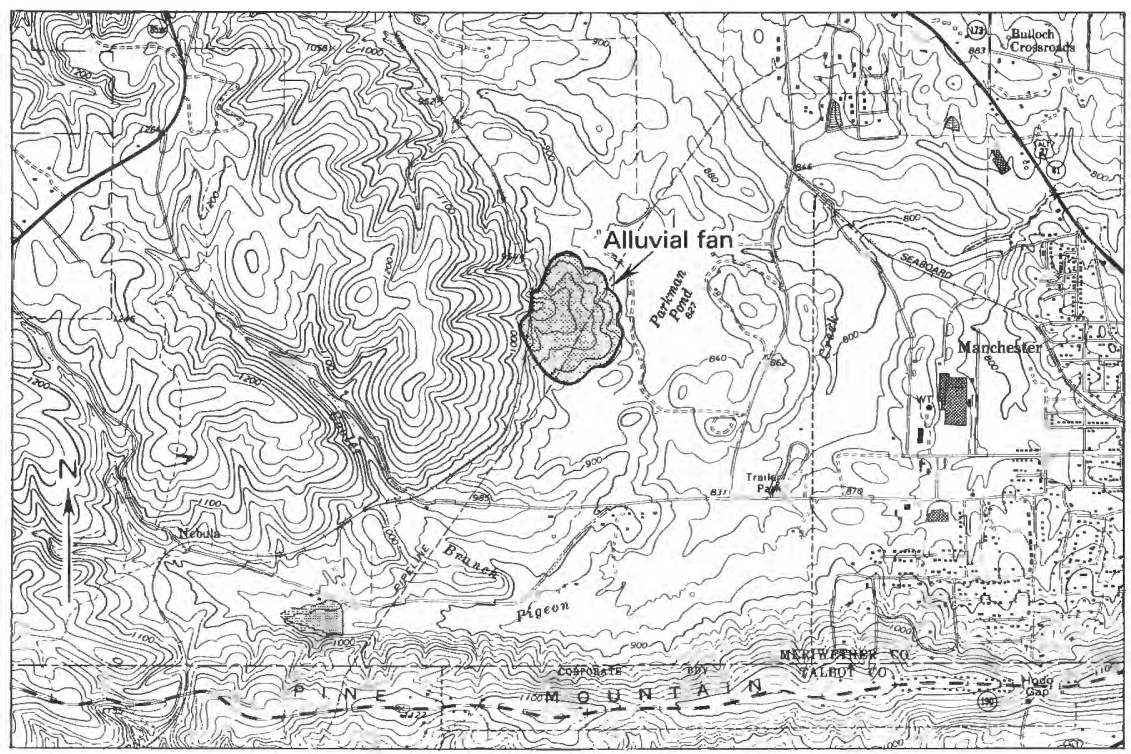

$\boldsymbol{A}$

Figure 11. An ancient, east-facing alluvial fan deposit exposed in a railroad cut near Parkman Pond in the Shiloh 7.5-min quadrangle of Georgia. A, Topographic expression of the alluvial fan showing that it is an erosional remnant of a much larger deposit; $B$, rounded cobble gravel in bedded alluvial fan deposit. Handle of entrenching tool is 21 in long.

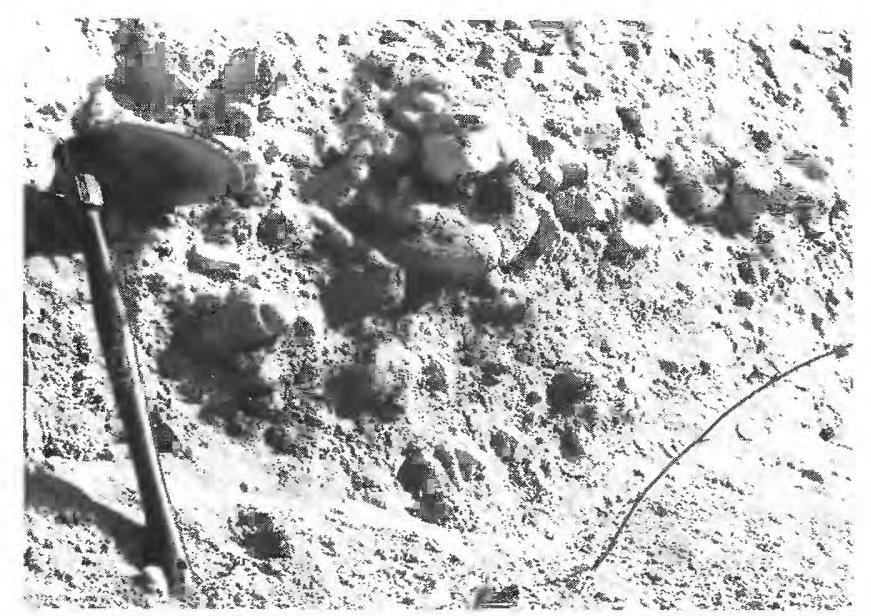

$\boldsymbol{B}$

Figure 11. Continued.

increasing clay percentage and decreasing micropermeability per horizon. This contrast is apparently due to some factor that (1) limits the total percentage (or mass) of clay that can form in these pedons and (2) limits the decrease in small pore volume and thereby in micropermeability.

Unlike Coastal Plain Ultisols that we have studied, the clay bulge in pedons $293-001$ and $199-002$ is evenly distributed with depth, and the maximum percentage of clay per horizon is restricted to about 30 percent. The limited clay content may simply reflect quartz-rich parent material (Hollis Quartzite), which has a low labile mineral content in both the sand and the silt fractions. Soils formed in situ in the Hollis are clay rich and have distinct clay maxima in the upper part of the B horizons.

The clay mineralogy of the fan soils does not suggest a bisequum or cumulative soil, because the trend of decreasing vermiculite and gibbsite relative to kaolinite in the fan soils is similar to that in soils developed in Coastal Plain sediments in Virginia (Markewich and others, 1987). The fan soil (pedon 199-002) has an abnormally high content of $10.1-\AA$ muscovite in its $\mathrm{Bt} 2,2 \mathrm{Bx} 1$, and $2 \mathrm{Bx} 2$ horizons, which may be related to a higher mica content in the parent material. It contains little or no clay-sized quartz. The most striking change revealed by XRD in the $\mathrm{Bx}$, relative to the $\mathrm{Bt}$ and $\mathrm{BA}$, is the decrease in clay-sized quartz. This decrease, which is coincident with the decrease of fine silt, suggests that quartz in the fine silt and clay fractions has been removed by dissolution.

There is no change in clay mineralogy in the $\mathrm{Bx}$ horizon of pedon 199-002, an indication that any cementation is caused by a noncrystalline, probably subclay-sized material. The chemistry (table 12D) indicates that the cementation may be due to amorphous iron, aluminum, or silica. These analyses are for pedon 199-002 but are considered representative for both fan soils. As is the case with other Ultisols, the maximum $\mathrm{Fe}_{2} \mathrm{O}_{3}+\mathrm{Al}_{2} \mathrm{O}_{3}$ correlates with the $\mathrm{Bt}$ horizon, and $\mathrm{Fe}_{2} \mathrm{O}_{3}+\mathrm{Al}_{2} \mathrm{O}_{3}$ decreases (along with $\mathrm{TiO}_{2}$ ) in the $\mathrm{Bx}$ horizon. 

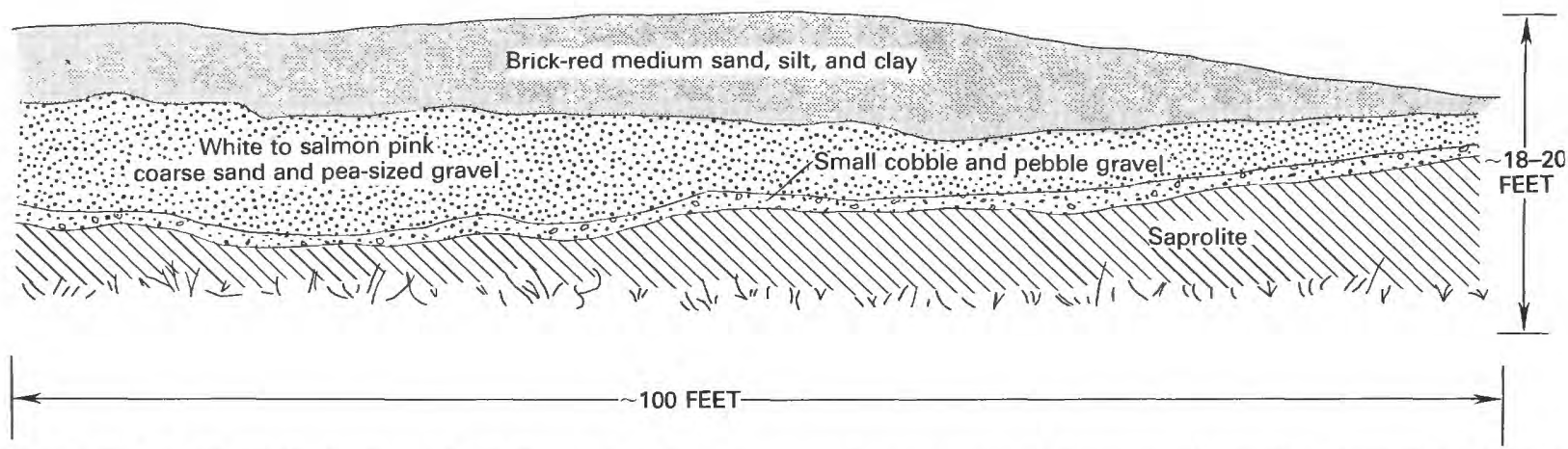

Figure 12. Eastern half of roadcut through a fining-upward sequence of terrace alluvium adjacent to White Sulphur Creek (see site 9, fig. 6F) showing its position as channel fill cut into metamorphic rocks that are now saprolitized. Because there is no evidence of mixing at the alluvium/saprolite contact, we interpret the saprolitization to be associated in time with subaerial exposure of the entire section.

It appears that the coincidence of the clay maximum and the $\mathrm{SiO}_{2}$ minimum in the $\mathrm{Bt}$ horizon is largely the result of silica depletion, as Markewich and others (1986, 1987) have suggested for Ultisols elsewhere in the Southeast. $\mathrm{SiO}_{2}$ depletion is not as intense in the $\mathrm{Bx}$ horizon as it is in the Bt horizon. It is not clear what limit exists on depth to the base of the $\mathrm{Bt}$ horizon or what controls the depth of the $\mathrm{Bt} / \mathrm{Bx}$ transition. Textural and chemical data indicate that processes do change across the $\mathrm{Bt} / \mathrm{Bx}$ boundary. The depletion of clay-sized and fine-silt-sized quartz in the Bx horizon indicates that silica dissolution did occur in the $\mathrm{Bx}$ horizon as well as in the Bt horizon.

We have not determined if there is any cementation in the $\mathrm{Bx}$ horizon. If there is cementation in the $\mathrm{Bx}$ horizon, it is either not silica (for example, it is $\mathrm{Fe}$ and $\mathrm{Al}$ ) or it is silica derived from the dissolution of quartz in this horizon or higher in the profile. It is also possible that silica cement accumulated in the Bx after the initial silica depletion.

There is some evidence that $\mathrm{Al}$ and $\mathrm{Fe}$ play a role in cementation. In pedon 293-001 (table 11C), we see an abrupt increase in dithionite-citrate extractable iron and aluminum in the Bx1 horizon relative to the Bt2 horizon. This increase may be the result of downward or lateral movement of amorphous or finely crystalline iron and aluminum colloids that act as cementing agents. As noted above, most of the cementation affects pores that contain 1/3-bar water rather than fine pores containing 15-bar water. Thus, the cementation that contributes to the bulk density increase occurs mostly in larger pores, probably owing to movement of iron and aluminum phases from the Bt horizon. The simplest hypothesis that can be drawn is that creation of porosity by silt dissolution results in trapping of colloids translocated from the Bt.

We did not reach the base of the Bx horizon in either profile, but we suspect that fragipan development is related to a lithologic-hydrologic discontinuity in the fan alluvium. The role of textural or hydrologic discontinuities is not clear but may be related to the slow rate of water and colloid movement from the finer grained near-surface sands to a coarser grained alluvial gravel.

In summary, both fan sites show well-developed profiles in which $\mathrm{Bt}$ horizons overlie Bx horizons. The development of the fragipan, which involved silt depletion by chemical weathering, appears to have postdated the phase of clay formation. One common feature in these pans is the small percentage of fine silt in the $\mathrm{Bx}$ horizon relative to that in the Bt horizon; another is the absence of clay-sized quartz in the Bx horizon. Pan formation in these soils may be related to the conditions associated with active quartz dissolution such as close packing of sand, kaolinite dissolution relative to vermiculite and gibbsite, and subsequent cementation by noncrystalline products of mineral alteration.

\section{Soil and Weathering Profiles in Terrace Alluvium}

Almost every creek, stream, and river in the study area has an adjacent terrace or terraces. The treads of these erosional terraces are planar surfaces formed by lateral erosion (planation) overlain by relatively thin deposits of alluvium. On the Flint River terraces, the capping alluvium is nowhere greater than $20 \mathrm{ft}$, and that thickness is only locally preserved as paleochannel deposits. Generally, alluvium of the Flint River terraces is 8 to $10 \mathrm{ft}$ thick. Terraces of Flint and Chattahoochee River tributaries are commonly overlain by 2 to $5 \mathrm{ft}$ of alluvium and have paleochannel deposits as thick as $15 \mathrm{ft}$ (fig. 12).

Commonly, terrace alluvium along smaller streams consists of a sequence of coarse sand and pebble gravel fining upward to medium and fine sand and no gravel. The red colors and higher percentages of clay in the near surface are the result of oxidation and pedogenesis. The best exposure of terrace material from a small stream is in a roadcut on the eastern side of White Sulphur Creek west of Durand (fig. 12). The changes in clay mineralogy with 
depth (samples taken every $2 \mathrm{ft}$ from the surface) characterize the weathering profile developed in the White Sulphur Creek terrace alluvium (fig. $8 F$ ).

Terrace material adjacent to larger streams and along the Flint River does not show the channel form, particlesize variation, or color variation seen in terrace alluvium of smaller streams. The weathered alluvium is red to redbrown in color and has relatively uniform grain-size distribution. Because the solum extends to bedrock, there is little to no weathered alluvium or $\mathrm{C}$ horizon. Our auger samples are from a high terrace (750 ft in altitude) about 4 mi east of Woodbury, between Elkins Creek and the Flint River, about 2 mi upstream from the Flint River Water Gap (fig. 1B). Particle-size distribution data and clay mineralogy data from this pedon are included in table 13 and figures $7 H$ and $8 E$. We do not describe the soils formed in the White Sulphur Creek or Flint River terrace alluvium.

\section{Landslides and Associated Weathering Profiles}

The smallest landslide identified in the area is shown in figure $10 \mathrm{~A}$. The slide is lobate and has a steep frontal toe and a hummocky upper surface. Relief on the surface morphology is low and not represented on the area topographic map (fig. $6 \mathrm{~A}$ ), which has a 20 -ft contour interval. The slide scarp or backwall can be seen in the aerial photograph (fig. 10A). This small slide has flowed out onto an older slide deposit that has no surface morphology but can be seen in the cut bank along Jeff Davis Road (fig. $10 A$ ). In the older slide deposit, clasts range from cobble to small boulder sized and are dominantly subangular. The combined older and younger slide deposits appear to be on but oblique to the local dip slope of the Hollis Quartzite.

Figure 13 shows the angularity of clasts in the older slide in comparison with the rounded clasts in alluvial fans shown in figure $11 B$. Rinds on clasts in the slide indicate long-term in place weathering. We sampled the upper $8 \mathrm{ft}$ of the weathering profile of the older landslide. X-ray diffraction patterns of these samples are shown in figure $8 G$. We made no attempt to sample and date the younger slide. We used the observable weathering characteristics of the older material to estimate the relative age of the older slide. The depth of oxidation and the degree of weathering of individual clasts, plus clay mineralogy and bulk chemistry data, all suggest that the older slide is at least as old as alluvial fan and debris-flow deposits in the area and therefore probably is no younger than early Pleistocene in age.

\section{Debris Flows}

Debris-flow deposits on the slopes of Pine Mountain are typical in that they all have narrow necks, lobate and hummocky toes, and surface layers (commonly a few feet thick) that are finer grained than the underlying material. The neck of one flow is about $300 \mathrm{ft}$ across. One of the best

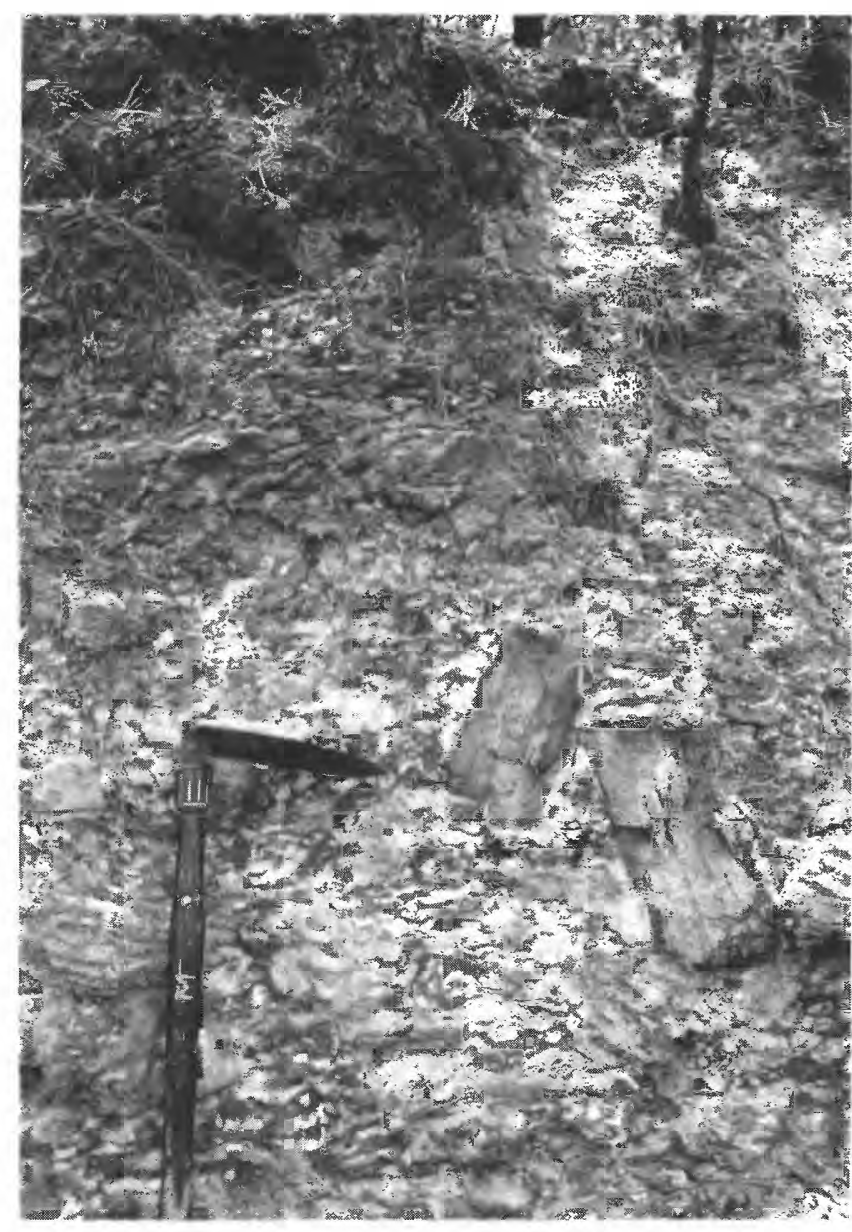

Figure 13. Small-boulder-sized clasts in a landslide deposit exposed along Jeff Davis Road on the southern side of Bull Trail Mountain. Note the angularity of the clasts and the thick weathering rind on the large clast in the center of the photograph (site 10, figs. $6 A, 8 G$, and $10 A)$. Handle of entrenching tool is 21 in long.

exposures through the necks of several adjacent flows is along a county road as it goes across Pine Mountain 1 to $1.5 \mathrm{mi}$ northwest of Hamilton, Ga. (figs. $1 A, B$ ). Topographic expression of these debris flows and cross sections through the necks of the flows are shown in figures 14 and $15 \mathrm{~A}-\mathrm{C}$. These exposures are 150 to $200 \mathrm{ft}$ above the base of the flows. The set of flows exposed along this section of road is about $1,500 \mathrm{ft}$ across. Coarse clasts ride on a base of mobilized saprolite (fig. 15B). Both the matrix and the included cobbles are oxidized and mottled throughout (fig. $15 D$ ). Included clasts are dominantly cobble to small boulder sized.

The toes of the flows northwest of Hamilton coalesce to form a large, lobate, hummocky skirt at the base of the mountain. This hummocky surface is not represented in the topography shown on the Pine Mountain SW 7.5-min quadrangle of Georgia (fig. 14), because surface relief of the hummocks is within the map's 20 -ft contour interval. 


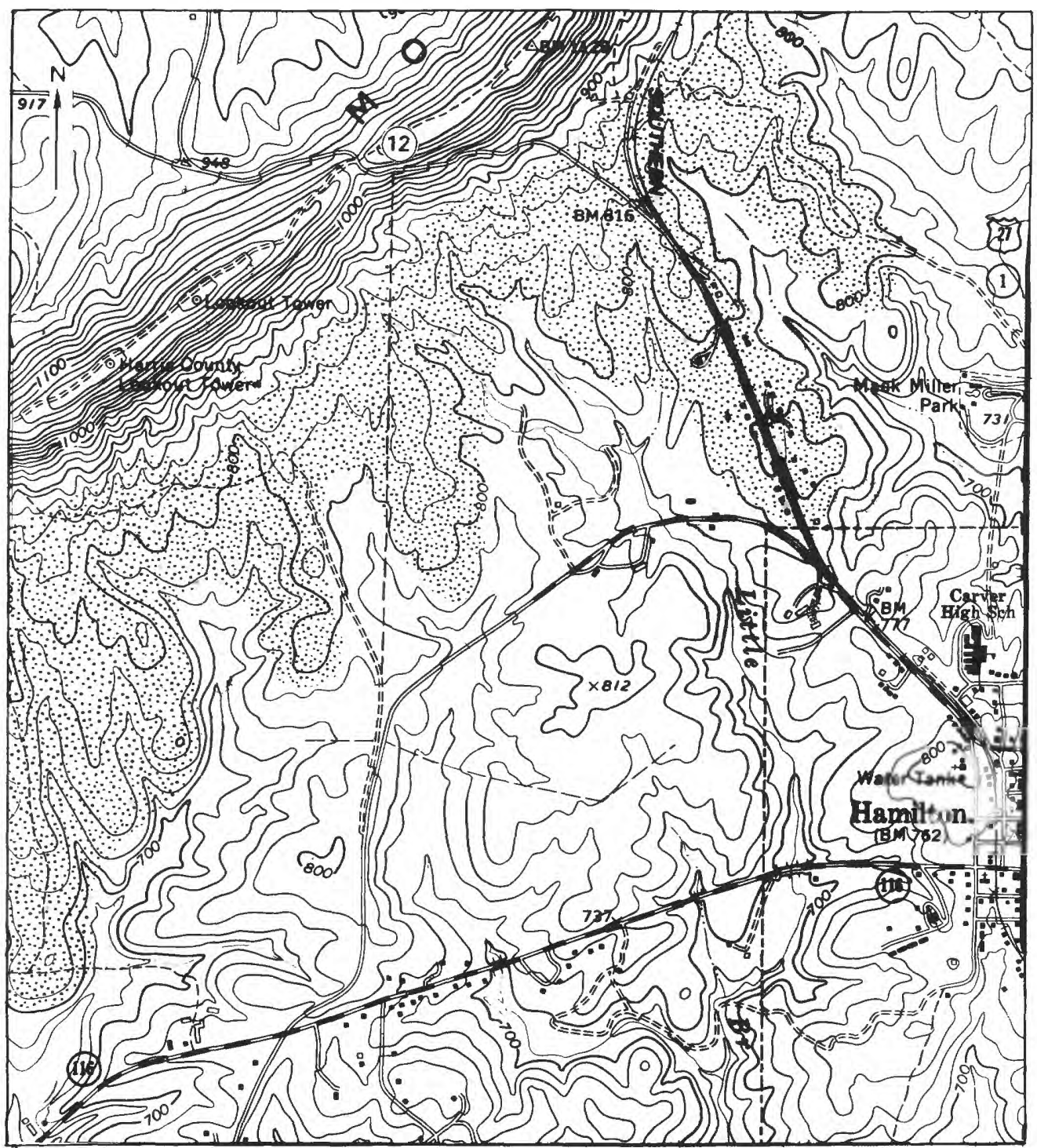

Figure 14. Topographic expression of SSE.-facing debris flows in the Pine Mountain SW 7.5-min quadrangle of Georgia. The stipple pattern shows the area of debris flow deposits northwest of Hamilton, Ga. Also shown is the location of sample site 12.

Figure $15 \mathrm{C}$ shows the contact between the debris-flow gravels and the underlying saprolite in the toe part of the flow. Unlike the contact shown in figure $15 B$, there is no mobilized saprolite beneath the debris-flow gravels.

Debris-flow deposits are present on the steeper slopes underlain by beds of resistant, massive Hollis Quartzite in the Pine Mountain area. They are present on both the northern and the southern slopes of Pine Mountain but are best exposed on the southern slopes. They appear to be restricted to the western part of the study area.

The debris flows near Hamilton are present on crossdip and dip slopes of massive orthoquartzite within the Hollis. They are more numerous and more distinctive on the cross-dip slopes. The upper sections or source areas of these debris flows cannot be seen in the present landscape.
There is no evidence of gullying or of any gravel lag. It is this lack of characteristic topography in the headward areas of the flows, the deep oxidation and mottling due to iron segregation, and the incision and dissection of the toes that indicate an age no younger than early Pleistocene for these deposits. No descriptions or mineralogic analyses are available for these deposits.

\section{DISCUSSION}

\section{Weathering and Relative Residence Times of Weathering Profiles}

In the Pine Mountain area, near-surface residual weathering profiles developed in place on weathered bed- 

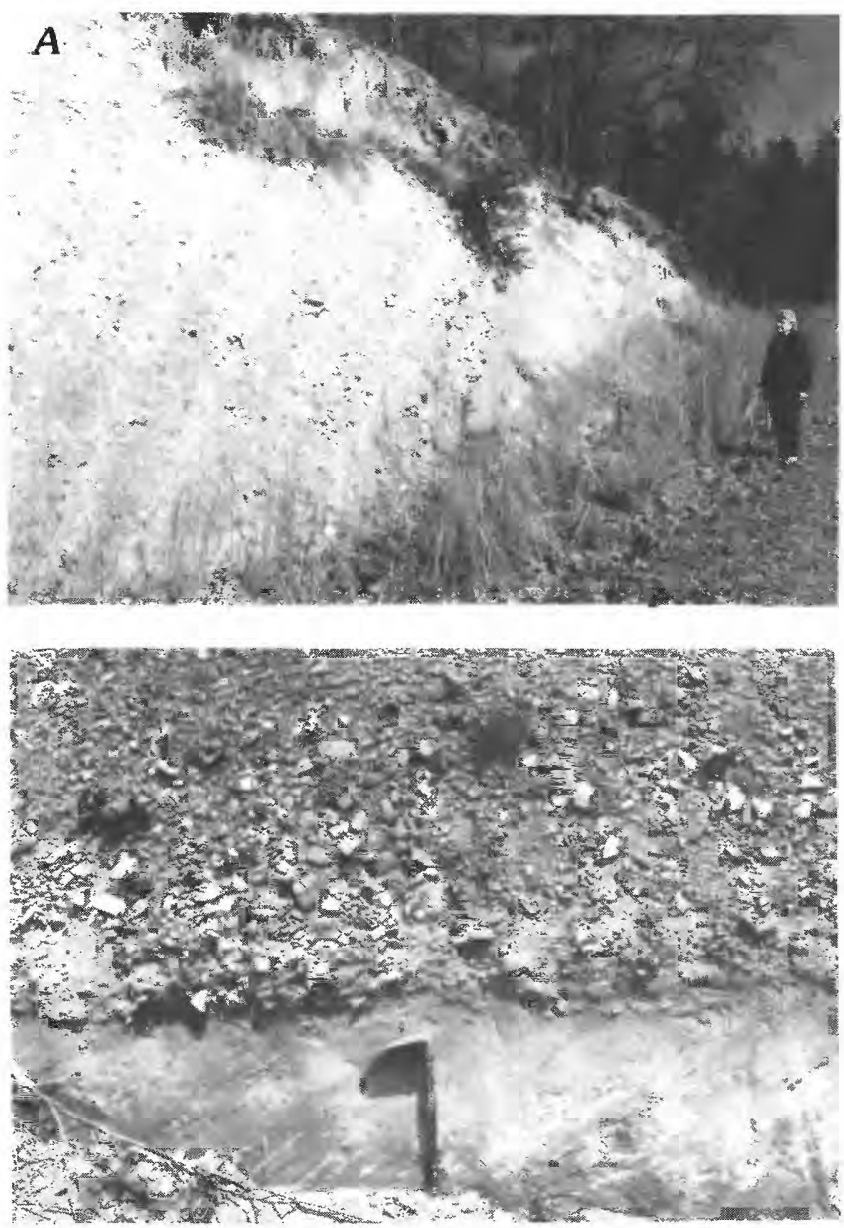

Figure 15. Site 12 (fig. 14) showing details of SSE.-facing debris flows. $A$, Channel-shaped cross section (about 150-200 ft higher than base of flow) showing contact with underlying saprolite. $B$, Closeup of angular clasts in debris-flow deposit and of the mobilized saprolite at the base of the flow. C, Contact near the toe of the debris

rock (saprolite) can be contrasted with profiles developed in transported parent materials. Lithotypes having residual soil and weathering profiles include weathered metamorphic micaceous schists, itacolumite (flexible, micaceous lithotype of the Hollis Quartzite), granite, and granitic gneiss. In the Pine Mountain area, residual soil and weathering profiles developed on schist are similar in thickness and profile zonation to profiles developed in steeply foliated lithologies throughout the Appalachian Piedmont south of Maryland. The thickest profiles are developed beneath upland drainage divides. Soil and weathering profiles thin markedly beneath steeper valley side slopes. Drilling beneath uplands underlain by schist typically penetrates 40 to $70 \mathrm{ft}$ of saprolite before hitting competent bedrock. Residual soil profiles exhibit thin $(70 \mathrm{~cm}$ thick or less) sola dominated by Bt horizons. A horizons are commonly less than $15 \mathrm{~cm}$ thick and often contain angular, residual vein quartz. The sola of residual soil developed in
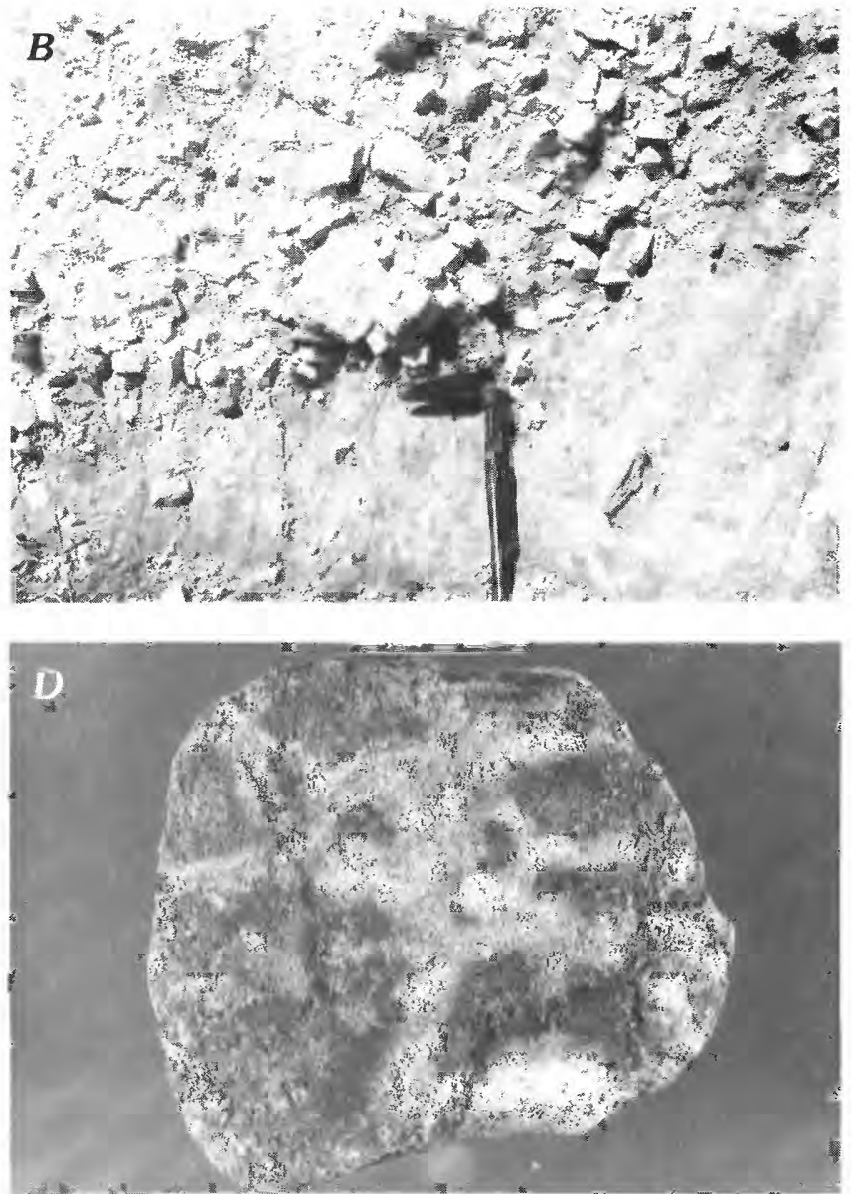

flow between transported material and saprolitized bedrock (abrupt contact suggests that saprolitization occurred after the debris flow). $D$, Mottled clast of Hollis Quartzite from the neck section of the debris flow. Handle of entrenching tool shown in $B$ and $C$ is 21 in long.

schist and gneiss grade downward into massive zones that grade into saprolite (Pavich and others, 1989). Where saprolite is exposed at the land surface, it is dominantly quartz and muscovite. Weatherable minerals such as feldspars and iron silicates have been altered by leaching. Oxidation of iron silicates and iron sulfides extends to the base of the saprolite. Joints and fractures in saprolite are commonly filled with clayey-textured manganese and iron-rich cutans. In the Pine Mountain area, the Hollis Quartizite is more deeply weathered than the surrounding schist. Exposures on Salter Mountain (fig. $1 B$, western end of Indian Grave Mountain) indicate that there is a minimum of $70 \mathrm{ft}$ of weathering. Well data suggest that the weathering is probably much deeper than $70 \mathrm{ft}$. Hewett and Crickmay (1937) suggested that meteoric water circulates to a depth of several hundred feet in the Hollis Quartize before migrating back to the surface and reemerging along a quartzite/schist contact as warm-water springs. Their argu- 
ment suggests that alteration of mineral phases other than quartz and muscovite may take place at considerable depth in the Hollis. Weathering in the itacolumite lithotype of the Hollis may be analogous to deep weathering in Pliocene quartzose barrier sands in Horry County, S.C. (Markewich and others, 1987). The high quartz content of the quartzite and of the marine barrier sand allows for development of a thick unsaturated zone and deep circulation of oxygenated, acidic water that reacts readily with labile mineral phases. The ubiquitous fractures and joints in the Hollis facilitate the downward movement of waters. By contrast, massive orthoquartzite lithotypes of the Hollis are much less weathered and crop out as resistant ledges near ridge crests in the western part of the study area. Dark brick red, clay-rich layers at the base of exposures in the Hollis on Indian Grave Mountain (itacolumite lithotype) are interpreted to be feldspathic and (or) sheared zones, but more work is needed to determine their actual origin.

Transported materials also vary in the depth and intensity of weathering. Locally transported colluvium can be relatively unweathered, particularly when it is composed of resistant, massive orthoquartzite blocks. Some of the deepest weathering in the area, however, occurs on debrisflow and alluvial-fan deposits that flank the major ridges. These fans are dissected remnants of larger late Tertiary or early Pleistocene fans that developed under climate and drainage/discharge conditions quite different from those of the present. Outcrop and drilling show that depth of weathering is at least $50 \mathrm{ft}$ in parts of the fans and that the intensity of weathering does not vary significantly with depth. This deep weathering is probably attributable to the highly porous fabric of the poorly sorted fan deposits. No data are available on the maximum thickness of fan deposits or the maximum depth of weathering.

Field and laboratory data pertaining to the relative degree of alteration suggest that, in general, soil and weathering profiles developed in alluvial-fan material and in Hollis Quartzite have longer residence times in the landscape than soil and weathering profiles developed in schist. Bt horizon thickness, clay mass, and development of fragic horizons are criteria, based on both field and laboratory data, that indicate residence-time differences between soil and weathering profiles developed in the three parent materials. Geomorphic field relations also support age differences.

The Piedmont surface developed on schist saprolite is lowered by a combination of volumetric collapse of saprolite to soil, desilication of soil in the Bt horizon, and soil surface erosion (Pavich and others, 1989). The short relative residence time of Piedmont soils in the Pine Mountain area is consistent with that model. Lowering of the Piedmont schists relative to the Hollis Quartzite probably occurs by long-term (for example, $10 \mathrm{Ma}$ or less) differential erosion of weathered and unweathered materials of varying erosional resistance and permeability. This obser- vation is consistent with the model put forward by Pavich and others (1985), which holds that typical Piedmont saprolite has a residence time of $1 \mathrm{Ma}$ or less.

The apparently greater erosional resistance of the Hollis Quartzite appears to be due to two factors. First, the chemical resistance of the massive orthoquartzite to weathering results in little chemical or mechanical alteration. Secondly, in areas of steep, narrow ridges underlain by highly jointed and fractured itacolumite, the combined effects of high porosity and permeability may be more important. These areas show no perennial drainage development. We hypothesize that rainwater quickly infiltrates the quartzite. Because there is little surface runoff, there is little or no mechanical erosion, a geomorphic environment similar to that of sand ridges in the Coastal Plain of South Carolina, Virginia, and Georgia (Markewich and others, 1986, 1987, 1990).

\section{Pedogenesis}

McCracken and others (1962) and Daniels and others (1987) have shown that most soils in the mountainous regions of North Carolina are Inceptisols formed in shallow colluvium overlying residual soils or saprolite. On the slopes of Pine Mountain, Inceptisols are coincident with near-surface lithic contacts. Most soils developed in colluvium or in colluvium/residuum mix that we have observed in the Pine Mountain area are Ultisols having argillic horizons.

Soils encountered in the Pine Mountain area fall into three distinct groups: (1) those formed in Piedmont saprolite, typified by the Cecil profile described herein, (2) those formed on quartz-rich residuum of the Hollis Quartzite, and (3) those formed on fan deposits derived from the Hollis Quartzite, which contain fragic horizons and are similar to soils developed in the Coastal Plain of central Georgia. We recognize that the climate of the Pine Mountain area was cooler during glacial periods in the Pliocene and Pleistocene, but all recognized soil properties can be explained by noncryogenic processes.

\section{Argillic Horizons}

The processes of formation of the argillic horizons have been discussed for the Piedmont by Pavich (1986) and for the Coastal Plain by Markewich and others (1986, 1987 ) and by authors referenced in their papers. The argillic horizons in all the pedons studied are kaolinitic. The kaolinite is probably derived from the alteration of feldspars, K-mica, and possibly from vermiculite derived from primary mica. Gibbsite is a minor constituent except in the very well drained mountain and fan sites. Perhaps the $\mathrm{H}_{4} \mathrm{SiO}_{4}$ concentrations of waters derived from the soils are too high for gibbsite to be stable. This instability is probable in a soil so rich in clay that $\mathrm{H}_{4} \mathrm{SiO}_{4}$ concentrations are 
high owing to a lack of drainage. The absence of vermiculite and gibbsite, except in the A horizon, is consistent with the evidence presented by Markewich and others (1987) that soil drainage controls the occurrence of these phases. These data suggest, therefore, that gibbsite is not macroclimatically controlled, as Owens and others (1983), Soller (1988), and Soller and Owens (1991) suggested, but is rather the result of soil microclimate and drainage. Because drainage is commonly related to time (increased dissection and incision), gibbsite may have a relation to time in areas where soils are as old as middle Pleistocene (1 Ma or older) and the land surface on which the soil has developed has been uplifted and (or) affected by eustatic change(s) in sea level.

\section{Desilication of Argillic Horizons}

Another, less certain argument for active desilication of the $\mathrm{Bt}$ horizon is the absence of clay-sized quartz in the Bt. Farther north in Virginia (Markewich and others, 1987) and North Carolina (Soller, 1988), quartz is present only as a minor constituent of the clay-sized fraction of $\mathrm{Bt}$ horizons in Coastal Plain soils. If clay-sized quartz is produced in these middle Atlantic Coastal Plain soils by the mechanical breakdown of sand- or silt-sized quartz grains, persistence of the clay-sized quartz may be due to dissolution rates that are slower than they are in the Georgia soils. This assumption is speculative but fits the observed mean annual temperature difference between Georgia and more northerly sites $\left(64.4^{\circ} \mathrm{F}\right.$ for Georgia, $60.8^{\circ} \mathrm{F}$ for North Carolina, and $55.4^{\circ} \mathrm{F}$ for Virginia). The physical breakdown of quartz may be less temperature dependent, or even enhanced by freeze/thaw cycles, relative to the chemical dissolution of quartz.

Rubification of soils occurs faster in Georgia soils than it does in soils of the Middle Atlantic States (Markewich and others, 1989). This difference, too, may reflect a difference in kinetics of processes between Middle Atlantic soils and soils of the Southeastern United States.

\section{Fragic Horizons}

Soils having fragic properties comprise a small percentage of the soils of the Southeastern United States. Their genesis may be related to age, parent material, and (or) climate. Ruhe and others (1975, p. 125) stated:

In the southeastern states the fragisols are mainly on older geomorphic surfaces (Daniels, et al., 1966), hence they may be relics of older environments (Grossman and Carlisle, 1969). However, their geographic distribution approximately coincides with a similar geographic band of stabilized sand dunes (Thorp and Smith, 1952) that reflect a relatively dry climatic episode during the Pleistocene (Whitehead, 1973).

Although we cannot comment on the parent material of fragic soils in the Coastal Plain, the data presented here

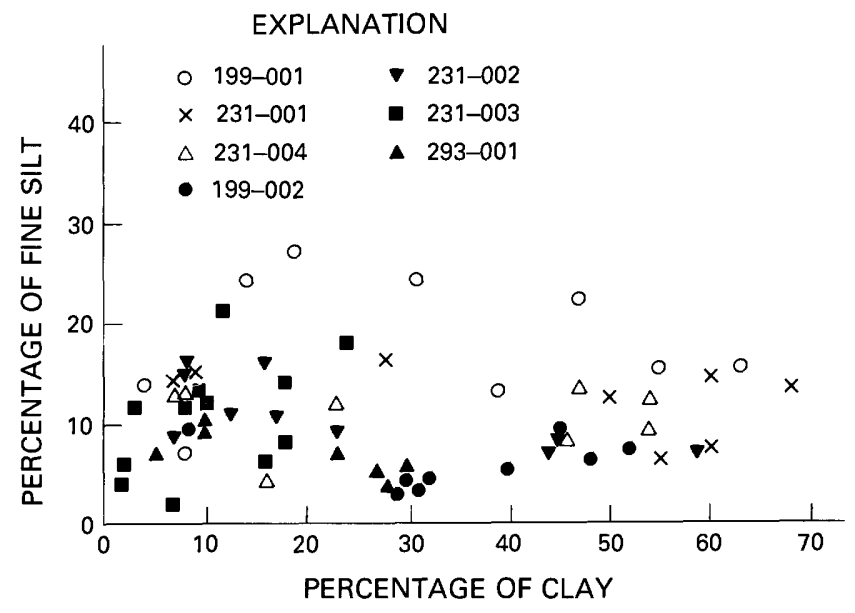

Figure 16. Percentage of fine silt versus the percentage of clay for all horizons of all sampled pedons.

show that soils having fragic horizons on the Pine Mountain fans are associated not with sand dunes but with old constructional morphostratigraphic units (for example, fan deposits) comprised of gravels and sands of resistant lithologies, dominantly quartzite. These units may be similar to sand dunes because they are both parent materials in which drainage is generally unimpeded.

The soils on the fans are unique in this area because they contain fragic horizons. Other constructional landforms, such as the slide block and the Flint River terrace, have soils that do not contain fragic horizons. Fragipans may, therefore, be a function of parent material differences, textural-hydrologic discontinuities, time, or a combination of all three. The effects of these factors of fragipan development have been discussed elsewhere (Grossman and Carlisle, 1969), and the general consensus is that fragic soils cannot be grouped by any simple taxonomic criteria.

Both the fragic and the nonfragic soils in the Pine Mountain area contain argillic horizons in the upper parts of their profiles. As they do in Coastal Plain soils elsewhere (Markewich and others, 1987), fine silt and clay increase in $\mathrm{Bt}$ horizons owing to physical and chemical alteration processes.

Figure 16 shows a plot of the percentage of fine silt versus the percentage of clay for all horizons of the sampled pedons. The plot shows that, for the complete data set, there is no trend in the ratio of fine silt to clay. It is significant, however, that the $\mathrm{Bt}$ horizons in the two fan soils (199-002, 293-001) containing fragipans or fragic horizons have the smallest fine silt content of any of the $\mathrm{Bt}$ horizons and that, for both soils, the fine-silt minimum coincides with a clay content of about 30 percent within horizons having well-developed fragic properties. The fine silt minima are taken as evidence that fine silt is lost by dissolution of quartz (and muscovite?) from the Bt horizon. 


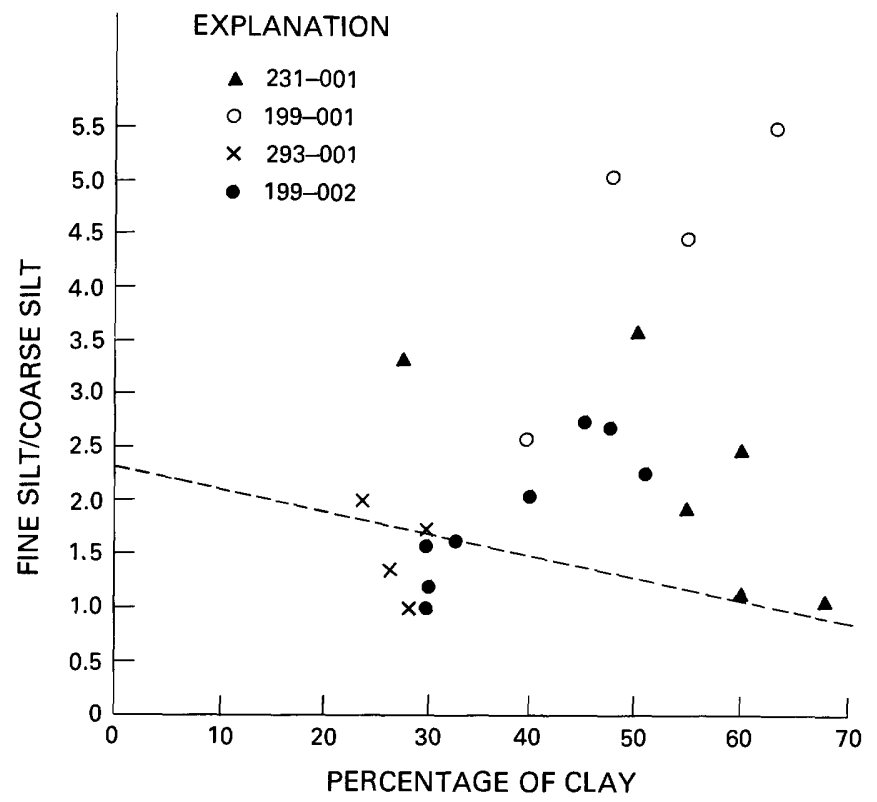

Figure 17. Ratio of fine silt to coarse silt versus the percentage of clay for pedons S84GA-231-001 (mountain), S84GA-199-001 (Piedmont), and S84CA-293-001 and S84GA-199-002 (fan). The dashed line separates argillic horizons from all but one of the fragic horizons..

The loss of fine silt relative to sand and clay appears to correlate with fragipan formation. Close packing of skeletal sand with interstitial clay (and possible cementation at skeletal sand-grain boundaries) could provide the brittleness (nonplasticity) and density observed in fragipans. Removal of silt by leaching would be a slow process and would fit the description of fragipans in Mississippi (Gauggel and Pettry, 1988, p. 257) as "...argillic horizons which have undergone leaching and clay illuviation prior to fragipan formation, which appears to be a gradual pedogenic process."

The ratio of fine silt to coarse silt versus the percentage of clay (fig. 17) and the line separating argillic (above) from fragic (below) horizons suggest two distinctly different trends in argillic and fragic horizon development:

1. A trend toward increasing fine silt and clay in the Ultisols developed on the Piedmont saprolite and Hollis Quartzite residuum.

2. A trend toward decreasing fine silt as clay increases to a limit of about 30 percent in fragipan. The clay may be limited by the parent minerals available to be altered (for example, mica and feldspar) or by the rate of translocation of clay. In the case of fan sites, both factors may limit the maximum percentage of clay in a horizon. Translocation of clay may be an active process in the coarse-textured and freely drained parent material. Once the pan begins to form, water retention below the rooting depth may promote fine silt and clay disso- lution rather than clay precipitation due to drying as in a Bt horizon. Loss of fine silt and some clay-sized material (including clay-sized quartz) could result in a clayey sand texture in a closely packed, high-density fabric.

\section{Age Estimates for Soils and Geomorphic Surfaces}

Because soils can be differentiated on different geomorphic surfaces, they allow us to determine relative ages of surfaces. We can bracket the intermediate age units between the oldest and youngest units as follows.

The oldest landscape elements are the fans. This argument is based on several observations:

1. The fans are geomorphic remnants that are isolated on the landscape. Their surface drainage is disconnected from the drainage net of surface waters off the mountain, and their surface morphology has evolved to the stage where alluvial channels are well entrenched into the fan surface, and headward erosion of Piedmont streams is cutting into fan heads and isolating them from the mountain slopes.

2. The total solum thickness, including argillic and fragic horizons, of the fan soils is several times greater than that of any of the mountain or Piedmont soils.

3. Regolith on the fans is oxidized to depths of 15 to $20 \mathrm{~m}$. By contrast, mountain regolith oxidation is restricted to depths of 7 to $12 \mathrm{~m}$, and the Piedmont regolith is oxidated to depths of 3 to $6 \mathrm{~m}$.

4. The degree of desilication of the fan soils is exceptional, particularly for the silica-rich parent material. Figure $18 A$, taken from a paper by Markewich and Pavich (1991), shows a plot of major oxides versus clay mass for several Southeastern U.S. soils. The exceptionally thick Pine Mountain fan soils and inner Coastal Plain soils (from Augusta, Ga.) are similar in having the greatest silica depletion and the greatest clay mass per square centimeter. The Augusta site is estimated to be about $10 \mathrm{Ma}$ on the basis of the age of the parent sediments and the geomorphic position of the site at the inner Coastal Plain margin (Pavich and others, 1981). Plotting chemistry against age (fig. 18B) for younger, relatively well dated Pleistocene sites and the Augusta site shows a trend of increasing desilication through time. The position of the fan site on that trend indicates that the fan soils probably exceed several millions years in age.

As we mentioned previously, fragipans are commonly thought to form beneath older surfaces on the Atlantic Coastal Plain (Grossman and Carlisle, 1969; Ruhe and others, 1975). Pans are also related to coarser textured parent materials that permit rapid drainage, clay translocation, and silt depletion. Data suggest that residence time on the landscape depends in part upon formation of a coarse epipedon that is relatively resistant to erosion. Long residence time can also be related to development of a closely 

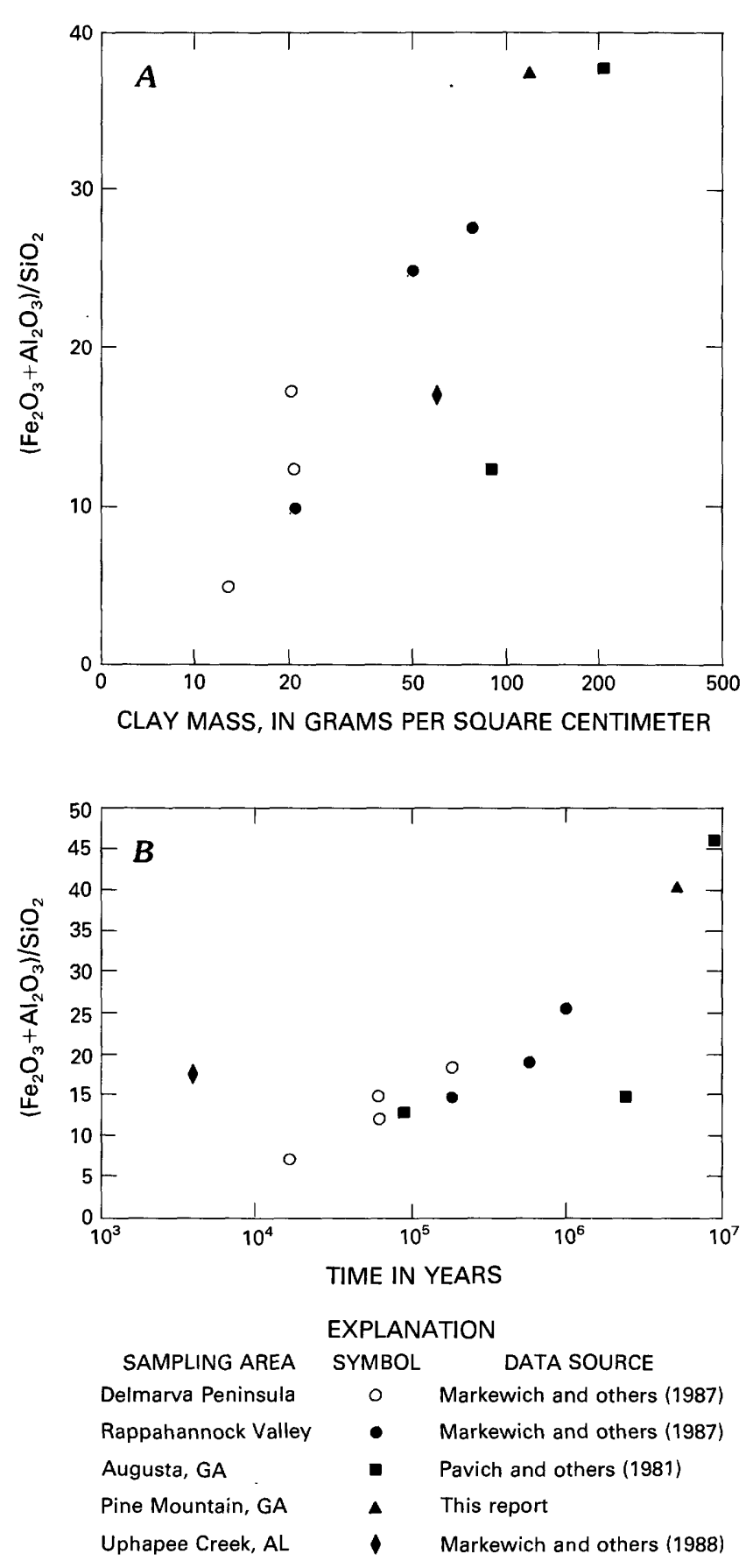

Figure 18. $A$, Relation of $\left(\mathrm{Fe}_{2} \mathrm{O}_{3}+\mathrm{Al}_{2} \mathrm{O}_{3}\right) / \mathrm{SiO}_{2}$ to clay mass. Clay mass (measured in grams of clay per square centimeter) is the product of the bulk density (measured in grams per cubic centimeter) times the percentage of clay times the thickness of the horizon for each horizon in the solum (from Markewich and Pavich, 1991, fig. 5, p. 230). $B$, Relation of solum $\left(\mathrm{Fe}_{2} \mathrm{O}_{3}+\mathrm{Al}_{2} \mathrm{O}_{3}\right) / \mathrm{SiO}$ to ages of depositional units showing progressive chemical alteration through time (from Markewich and others, 1989, fig. 8, p. D17; Markewich and Pavich, 1991, fig. 5, p. 230).

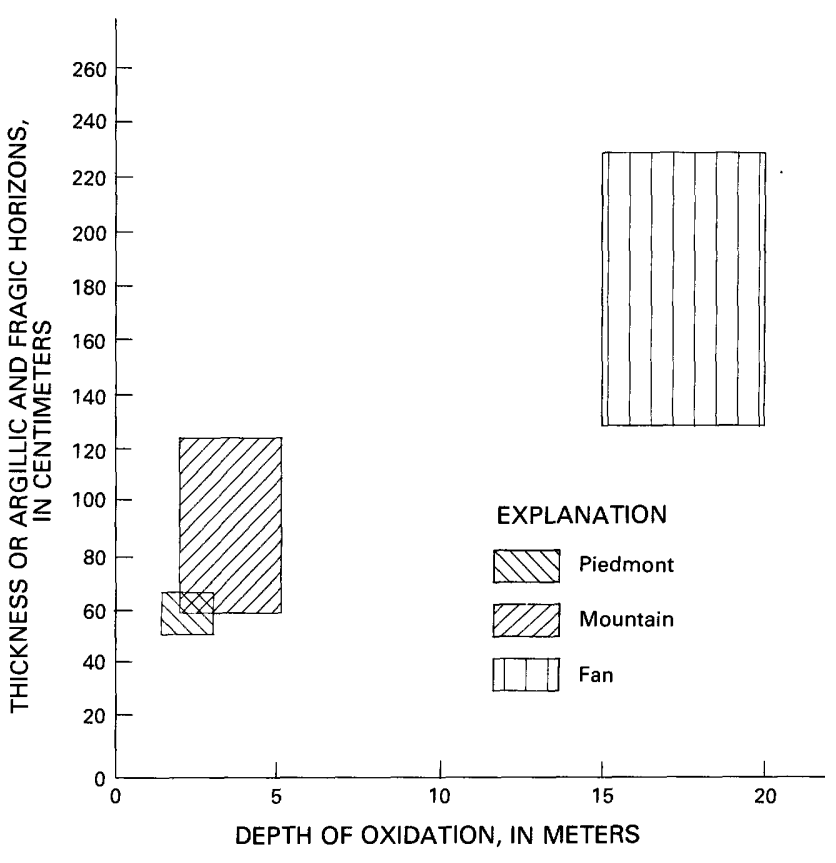

Figure 19. Comparison of thicknesses of argillic and fragic horizons to depths of oxidation for fan, mountain, and Piedmont soils.

packed, high-consistence structural pan that adds to slope stability by resisting creep. The data presented in figure 16 make it plausible to suggest that not only is fine silt depletion important to some types of fragipan formation but also that it is a qualitative index to the residence time of soils having fragic properties. In soils on schist and quartzite, we do not observe such depletion.

Data indicate that the soil developed in residuum of Piedmont granite gneiss is the youngest. The soil (Cecil) is similar in thickness, color, fabric, clay content, and chemistry to other residual soils developed elsewhere on saprolite between Virginia and Georgia. On the basis of geomorphic and geochemical data, Pavich (1989) argued that the residual Piedmont soil in Virginia is less than $2 \mathrm{~m} . y$. old. Comparison of Piedmont soil characteristics plotted by Markewich and Pavich (1991) for other Southeastern soils supports the argument that the Piedmont soils are younger that a few million years and may have residence times on the landscape of a few hundred thousand to a million years.

On the basis of comparison of mountain soil characteristics with the fan and Piedmont soils, we conclude that the mountain soils are of intermediate age; that is, they have residence times of a few hundred thousand to a few million years. Figure 19 shows solum thickness plotted against depth of oxidation for the study sites. This plot shows the intermediate nature of the mountain soils. Despite differences in parent materials, microclimate, drainage, vegetation, and slope, we assert that this plot is a reasonable indicator of relative age of the mountain soils. 
We compared the properties (other than fragic) of soils in the Pine Mountain area with those of soils developed in other areas of the Southeastern United States (Markewich and others, 1990, fig. 8, open triangle). Relative residence times-Piedmont soils are younger than mountain soils, which are younger than fan soils - are consistent with the observed (1) relative thickness of B horizons, (2) relative solum thickness, (3) clay mass in grams per square centimeter, and (4) $\left(\mathrm{Fe}_{2} \mathrm{O}_{3}+\mathrm{Al}_{2} \mathrm{O}_{3}\right) /$ $\mathrm{SiO}_{2}$ in soil $\mathrm{B}$ horizons. All of these properties (tables 6-13, figs. 17-19) indicate that the fan sites have had significantly longer residence times than either mountain or Piedmont soils.

The pedogenic development and truncation of upper $\mathrm{Bt}$ horizons indicate that this residence-time sequence is due primarily to relative erosion rates in the different soilforming environments rather than to a limit on the progressive alteration of parent material. Figure 18 shows that the constructional landforms in the Coastal Plain and Piedmont having sandy epipedons have soils that developed in time periods of $10^{5}$ to $10^{6}$ years. Pedon characteristics indicate that they have experienced minimal erosion relative to mountain and Piedmont soils in the Pine Mountain area. Mountain soils, which have residence times intermediate between those of the fan soils and those of the Piedmont soils, are apparently less eroded than Piedmont soils. However, the range in the degree of development of the mountain soils (tables 8,9$)$ is also the result of profile truncation by erosion, which is largely a function of landscape position. In a general sense, Piedmont soils have the shortest residence times, primarily because the clay-rich, lowpermeability $\mathrm{Bt}$ horizon facilitates runoff and enhances surface erosion of fine particles.

\section{SUMMARY}

The general relations between soils and landscape described herein are consistent with patterns observed elsewhere in the Appalachian Piedmont. Investigating the soil/ geomorphic relations in an area can establish a relative chronology of landforms that, in turn, can be a valuable tool in determining the geomorphic history of that area. The USGS and the SCS have worked together in the Piedmont of Georgia as part of a larger effort to study the relations between geology and soils in the Middle Atlantic and Southeastern States. This regional study included both the Atlantic Coastal Plain and the Piedmont physiographic provinces of the Eastern United States. The two primary objectives of the regional study were to determine (1) the type and rate of processes active in weathering and pedogenesis and (2) if and how soil and weathering profile data could be used to estimate ages of surfaces and (or) deposits.

The data from Pine Mountain indicate that, in an area where there are few local differences in temperature and precipitation, soils vary depending on the composition and texture of parent material and time. The data also corroborate previous regional studies (Markewich and others, 1990 ) in showing that the Piedmont is largely a Pleistocene landscape and that erosion on foliated metasedimentary rocks in the Piedmont is faster than that on deposits of transported material having high quartz sand content. In the Pine Mountain area, we suggest that soils developed on the narrow quartzite ridges and on the schists and gneisses are Pleistocene in age and that soils developed in transported material such as terrace and fan alluvium and debris-flow conglomerate are probably late Miocene-Pliocene in age.

\section{REFERENCES CITED}

Bailey, J.F., Patterson, J.L, and Pauhus, J.L.H., 1975, Hurricane Agnes rainfall and floods, June-July 1972: U.S. Geological Survey Professional Paper 924, 403 p.

Bates, R.L., and Jackson, J.A., eds., 1987, Glossary of geology (3d ed.): Falls Church, Va., American Geological Institute, $788 \mathrm{p}$.

Bentley, R.D., and Neathery, T.L., 1970, Geology of the Brevard fault zone and related rocks of the inner Piedmont of Alabama: University, Ala., Alabama Geological Society, 8th annual field trip guidebook, $119 \mathrm{p}$.

Carter, R.F., and Stiles, H.R., 1983, Average annual rainfall and runoff in Georgia, 1941-1970, in Hydrologic atlas 9: Atlanta, Georgia Department of Natural Resources, 1 pl.

Christopher, R.A., Prowell, D.C., Reinhardt, Juergen, and Markewich, H.W., 1980, The stratigraphic and structural significance of Paleocene pollen from Warm Springs, Georgia: Palynology, v. 4, p. 105-124.

City of Warm Springs, 1993, A brief history of Warm Springs: City of Warm Springs, in celebration of its 100th year as a city, December 20, 1893-1993: 72 p.

Clarke, J.W., 1952, Geology and mineral resources of the Thomaston quadrangle, Georgia: Georgia Department of Mines, Mining, and Geology Bulletin 59, 99 p.

Daniels, R.B., Gamble, E.E., Wheeler, W.H., and Nettleton, W.D. 1966, Coastal Plain stratigraphy and geomorphology near Benson, North Carolina: Southeastern Geology, v. 7, p. 159-182.

Daniels, W.L., Everett, C.J., and Zelazny, L.W., 1987, Virginia hardwood forest soils of the southern Appalachian Mountains, pt. 1, Soil morphology and geomorphology: Soil Science Society of America Journal, v. 51, p. 722-729.

Delcourt, H.R., and Delcourt, P.A., 1985, Quaternary palynology and vegetational history of the southeastern United States, in Bryant, V.M., Jr., and Holloway, R.G., eds., Pollen records of late Quaternary North American sediments: American Association of Stratigraphic Palynologists Foundation, p. 1-37.

Dyar, T.R., and Stokes, W.R., 1973, Water temperatures of Georgia streams: U.S. Geological Survey Water Resources Division, prepared for the Georgia Department of Natural Resources Environmental Protection Division, 317 p.

Gauggel, C.A., and Pettry, D.E., 1988, Genesis of soils with fragipans in Mississippi [abs.]: American Society of 
Agronomy annual meeting, 80th, Anaheim, Calif., Agronomy Abstracts, p. 257.

Grossman, R.B., and Carlisle, F.J., 1969, Fragipan soils of the eastern United States: Advances in Agronomy, v. 21, p. 237-279.

Hack, J.T., 1982, Physiographic divisions and differential uplift in the Piedmont and Blue Ridge: U.S. Geological Survey Professional Paper 1265, 49 p.

Harper, R.M., 1903a, Botanical explorations in Georgia during the summer of 1901 , pt. I, Itinerary: Bulletin of the Torrey Botanical Club, v. 30, p. 282-295.

1903b, Botanical explorations in Georgia during the summer of 1901, pt. II, Noteworthy species: Bulletin of the Torrey Botanical Club, v. 30, p. 319-342.

Harris, W.G., Hollien, K.A., and Carlisle, V.W., 1989, Pedon distribution of minerals in coastal plain Paleudults: Soil Science Society of America Journal, v. 53, p. 1901-1906.

Hewett, D.F., and Crickmay, G.W., 1937, The warm springs of Georgia, their geologic relation and origins, a summary report: U.S. Geological Survey Water-Supply Paper 819 , $40 \mathrm{p}$.

Higgins, M.W., Atkins, R.L., Crawford, T.J., Crawford, R.E., III, Brooks, Rebekah, and Cook, R.B., 1988, The structure, stratigraphy, tectonostratigraphy, and evolution of the southernmost part of the Appalachian orogen, Georgia and Alabama: U.S. Geological Survey Professional Paper 1475, $173 \mathrm{p}$.

Jones, S.B., Jr., 1974, The flora and phytogeography of the Pine Mountain region of Georgia: Castanea, no. 39, p. 113-149.

Kohler, M.A., Nordenson, T.J. , and Baker, D.R., 1959, Evaporation maps for the United States: U.S. Weather Service Technical Paper 37, 13 p.

Markewich, H.W., and Markewich, William, 1994, An overview of Pleistocene and Holocene inland dunes in Georgia and the Carolinas: U.S. Geological Survey Bulletin 2069, 32 p.

Markewich, H.W., and Pavich, M.J., 1991, Soil chronosequence studies in temperate to subtropical, low-latitude, low relief terrain with data from the eastern United States: Geoderma, v. 51 , p. $213-239$.

Markewich, H.W., Pavich, M.J., and Buell, G.R., 1990, Contrasting soils and landscapes of the Piedmont and Coastal Plain, eastern United States: Geomorphology, v. 3, p. 417-447.

Markewich, H.W., Pavich, M.J., Mausbach, M.J., Hall, R.L., Johnson, R.G., and Hearn, P.P., 1987, Age relations between soils and geology in the Coastal Plain of Maryland and Virginia: U.S. Geological Survey Bulletin 1589-A, 34 p.

Markewich, H.W., Pavich, M.J., Mausbach, M.J. Stuckey, B.N., Johnson, R.G., and Gonzalez, V.M., 1986, Soil development and its relation to the ages of morphostratigraphic units in Horry County, South Carolina: U.S. Geological Survey Bulletin 1589-B, 61 p.

Markewich, H.W., Pavich, M.J., Mausbach, M.J., Johnson, R.G., and Gonzalez, V.M., 1989, A guide for using soil and weathering profile data in chronosequence studies of the Coastal Plain of the Eastern United States: U.S. Geological Survey Bulletin 1589-D, 39 p.

McCallie, S.W., 1913, A preliminary report on the mineral springs of Georgia: Geological Survey of Georgia Bulletin $20,190 \mathrm{p}$.
McCracken, R.J., Shanks, R.E., and Clebsch, E.E., 1962, Soil morphology and genesis at higher elevations of the Great Smokey Mountains: Soil Science Society of America Proceedings, v. 36, p. 384-388.

National Oceanic and Atmospheric Administration,1974, Hourly precipitation data, Georgia: v. 24, no. 4.

1986, Hourly precipitation data, Georgia: v. 36, nos. 5, 6, and 7.

Owens, J.P., Hess, M.M., Denny, D.S., and Dwornik, E.J., 1983, Postdepositional alteration of surface and near-surface minerals in selected Coastal Plain formations of the Middle Atlantic States: U.S. Geological Survey Professional Paper 1067-F, 45 p.

Pavich, M.J., 1989, Regolith residence time and the concept of surface age of the Piedmont "peneplain," in Gardner, T.W., and Sevon, W.D., eds., Appalachian geomorphology: Geomorphology, v. 2, p. 181-196.

1986, Processes and rates of saprolite production and erosion on foliated granitic rock of the Virginia Piedmont, in Colman, S.M., and Dethier, D.P., eds., Rates of chemical weathering of rocks and minerals: Academic Press, New York, p. 551-590.

Pavich, M.J., Brown, Louis, Valette-Silver, J.N., Klein, Jeffrey, and Middleton, Roy, $1985,{ }^{10} \mathrm{Be}$ analysis of a Quaternary weathering profile in the Virginia Piedmont: Geology, v. 13, p. 39-41.

Pavich, M.J., Leo, J.W., Obermeier, S.F., and Estabrook, J.R., 1989, Investigations of the characteristics, origin, and residence time of the upland residual mantle of the Piedmont of Fairfax County, Virginia: U.S. Geological Survey Professional Paper 1352, $58 \mathrm{p}$.

Pavich, M.J., Newell, W.L., Mausbach, M.J., and Paulk, H., 1981, Geomorphology of the inner Coastal Plain margin near Augusta, Georgia: A guidebook of the Soil Science Society of America Meeting, December 3-5, 1981, Atlanta, Georgia: Madison, Wisc., Soil Science Society of America, 61 p.

Plummer, G.L., 1983, Georgia rainfall: Precipitation patterns at 23 places, 1734-1982: Atlanta, Georgia Academy of Science, $119 \mathrm{p}$.

Prowell, D.C., 1987, Cretaceous and Cenozoic tectonism on the Atlantic Coastal margin, in Sheridan, R.E., and Grow, J.S., eds., The geology of North America, v. I-2, The Atlantic continental margin, U.S.: Boulder, Colo., Geological Society of America, p. 557-564.

Radford, A.E., and Martin, D.L., 1975, Potential ecological natural landmarks, Piedmont region, Eastern United States: Chapel Hill, Department of Botany, University of North Carolina, 249 p.

Reinhardt, Juergen, Prowell, D.C., and Christopher, R.A., 1984a, Evidence for Cenozoic tectonism in the southwest Georgia Piedmont: Geological Society of America Bulletin, v. 95 , p. $1176-1187$.

Reinhardt, Juergen, Estabrook, J.R., and Prowell, D.C., 1984b, Maps, logs, and trench summaries from sedimentary deposits near Warm Springs, Georgia: U.S. Geological Survey Miscellaneous Field Studies Map MF-1551, 2 sheets.

Ruhe, R.V., Brunson, K.L., and Hall, L.E., 1975, Fragisols and Holocene environments in Midwestern U.S.A.: Anais da Academia Brasileira de Ciencias, v. 47 (supp.), p. 120-126. 
Schamel, Steven, and Bauer, D.T., 1980, Remobilized Grenville in the Pine Mountain window, in Wones, D., ed., The Calendonides in the U.S.A.: Blacksburg, Virginia Polytechnic Institute Department of Geological Sciences Memoir 2, p. 313-316.

Schamel, Steven, Hanley, T.B., and Sears, J.W., 1980, Geology of the Pine Mountain window and adjacent terrains in the Piedmont province of Alabama and Georgia, in Geological Society of America Southeastern Section, 29th annual meeting field trip guidebook: University, Ala., University of Alabama and Alabama Geological Society, 69 p.

Sears, J.W., and Cook, R.B., 1984, An overview of the Grenville basement complex of the Pine Mountain window, Alabama and Georgia, in Bartholomew, M., ed., The Grenville event in the Appalachians and related topics: Geological Society of America Special Paper 194, p. 281-287.

Sears, J.W., Cook, R.B., and Brown, D.E., 1981, Tectonic evolution of the western part of the Pine Mountain window and adjacent lnner Piedmont Province, in Sears, J.W., ed., Contrasts in tectonic style between the inner Piedmont terrain and the Pine Mountain window in eastern Alabama and adjacent Georgia: University, Ala., Alabama Geological Society, 18th annual field trip guidebook, p. 1-14.

Smith, R.W., 1929, Sedimentary kaolins of the Coastal Plain of Georgia: Geological Survey of Georgia Bulletin 44, 482 p.
Soil Survey Staff, 1972, Soil Survey laboratory methods and procedures for collecting samples: Soil Conservation Service Soil Survey Investigations Report 1, 63 p.

Designations for master horizons and layers in soil: New York, Cornell University, Department of Agronomy, $16 \mathrm{p}$.

Soller, D.R., 1988, Geology and tectonic history of the lower Cape Fear River valley, southeastern North Carolina: U.S. Geological Survey Professional Paper 1466-A, 60 p.

Soller, D.R., and Owens, J.P. , 1991, The use of mineralogic techniques as relative age indicators for weathering profiles on the Atlantic Coastal Plain, U.S.A.: Geoderma, v. 51, p. 111-131.

Thorpe, J., and Smith, H.T.U., 1952, Pleistocene eolian deposits of the United States, Alaska, and parts of Canada: Boulder, Colo., Geological Society of America, scale 1: 2,500,000.

Wells, R.D., 1965, Soil survey of Meriwether County, Georgia: Washington, D.C., Soil Conservation Service, 85 p.

Wharton, C.H., 1977, The natural environments of Georgia: Atlanta, Georgia Department of Natural Resources, 227 p.

White, W.S., 1965, Bauxite deposits of the Warm Springs district, Meriwether County, Georgia: U.S. Geological Survey Bulletin 1199-I, 15 p.

Whitehead, D.R., 1973, Late-Wisconsin vegetational changes in unglaciated eastern North America: Quaternary Research, v. 3 , p. $621-631$. 
Tables 6-14 
Table 6A. Field description of pedon S84GA-199-001

[Site 1, Cecil Series, $32^{\circ} 57^{\prime} 17^{\prime \prime}$ N., $84^{\circ} 37^{\prime} 20^{\prime \prime}$ W., Meriwether, County, Ga., $10 \mathrm{~km} \mathrm{NE}$. of Warm Springs, $700 \mathrm{~m} \mathrm{NW.} \mathrm{of} \mathrm{Cane} \mathrm{Creek,} 100 \mathrm{~m} \mathrm{SE}$. of Georgia Highway $85 \mathrm{~W}$, Woodbury 7.5-min quadrangle. Parent material is mica schist; surface elevation $248 \mathrm{~m}$ above mean sea level on a 2-percent planar upland slope of the Piedmont. Vegetation dominantly pine forest and some hardwood. Site is well drained under a udic moisture regime. -, none observed]

\begin{tabular}{|c|c|c|c|c|c|c|c|c|}
\hline $\begin{array}{l}\text { Depth } \\
\text { (cm) }\end{array}$ & Horizon & Moist color ${ }^{1}$ & Texture $^{3}$ & Structure ${ }^{4}$ & Consistence $^{5}$ & Clay skins ${ }^{6}$ & Roots $^{7}$ & Boundary $^{8}$ \\
\hline $0-15$ & A & $5 Y R 4 / 4$ & sl & $1 \mathrm{fgr}$ & $\mathrm{vf}$ & - & $\mathrm{mf}$ & as \\
\hline $15-33$. & Bt1 & $2.5 \mathrm{YR} 4 / 8$ & $\mathrm{cl}$ & $2 \mathrm{msbk}$ & $\mathrm{f}$ & $\mathrm{f}, \mathrm{t}$ & $\mathrm{mf}$ & $\mathrm{cs}$ \\
\hline $33-79 \ldots \ldots \ldots \ldots$ & Bt2 & $2.5 Y R 4 / 6$ & c & $2 \mathrm{mabk} / \mathrm{sbk}$ & f & $p, t$ & - & cw \\
\hline $79-104 \ldots \ldots \ldots \ldots$ & $\mathrm{BC}$ & $\begin{array}{l}2.5 \text { YR4/6 } \\
27.5 \text { YR5/8 }\end{array}$ & $\mathrm{cl}$ & $1 \mathrm{mabk} / \mathrm{sbk}$ & f & - & - & gw \\
\hline 104-154. & $\mathrm{B} / \mathrm{C}$ & $\begin{array}{l}2.5 \text { YR } 4 / 8- \\
7.5 \text { YR } 5 / 8\end{array}$ & $\mathrm{cl}$ & $1 \mathrm{mabk}$ & f & - & - & $\mathrm{cw}$ \\
\hline $154-216 \ldots \ldots \ldots$ & $\mathrm{C} 1$ & $\begin{array}{l}2.5 \text { YR } 4 / 8- \\
27.5 \text { YR5/8 }\end{array}$ & 1 & $\mathbf{M}$ & $\mathrm{vf}$ & - & - & $\mathrm{ci}$ \\
\hline $216-254$. & $\mathrm{C} 2$ & $2.5 \mathrm{YR} 4 / 8$ & 1 & $\mathbf{M}$ & $\mathrm{vf}$ & - & - & $\mathrm{cw}$ \\
\hline 254-304 . & $\mathrm{C} 3$ & & fsl & & $\mathrm{vf}$ & - & - & \\
\hline
\end{tabular}

${ }^{1}$ Munsell notation. A dash following a color notation indicates the presence of point colors or intergrades.

${ }^{2}$ Mottles.

${ }^{3}$ l, loam; fsl, fine sandy loam; sl, sandy loam; cl, clay loam; c, clay.

${ }^{4} 1$, weak; 2 , moderate; f, fine; $\mathrm{m}$, medium; gr, granular; abk, angular blocky; sbk, subangular blocky; $\mathrm{M}$, massive.

${ }^{5}$ f, friable; vf, very friable.

${ }^{6} \mathrm{f}$, faint; $\mathrm{p}$, prominent; $\mathrm{t}$, thin.

$7 \mathrm{mf}$, many fine.

${ }^{8}$ as, abrupt smooth; cs, clear smooth; cw, clear wavy; gw, gradual wavy; ci, clear irregular.

Table 6B. Textural analyses of horizons for pedon S84GA-199-001

[Sampled as Cecil; clayey, kaolinitic, thermic Typic Kandhapludult. Grain size in millimeters; all other values in weight percent. VF, very fine; F, fine; M, medium; C, coarse; VC, very coarse]

\begin{tabular}{|c|c|c|c|c|c|c|c|c|c|c|c|c|}
\hline \multirow[b]{2}{*}{$\begin{array}{l}\text { Depth } \\
(\mathrm{cm})\end{array}$} & \multirow[b]{2}{*}{ Horizon } & \multicolumn{3}{|c|}{ Total } & \multirow{2}{*}{$\frac{\text { Clay }}{F}$} & \multicolumn{2}{|c|}{ Silt } & \multicolumn{5}{|c|}{ Sand } \\
\hline & & $\begin{array}{c}\text { Clay } \\
(<.002)\end{array}$ & $\begin{array}{c}\text { Silt } \\
(.002-.05)\end{array}$ & $\begin{array}{l}\text { Sand } \\
(.05-2)\end{array}$ & & $\begin{array}{c}F \\
(.002-.02)\end{array}$ & $\begin{array}{c}\mathrm{C} \\
(.02-.05)\end{array}$ & $\begin{array}{c}\text { VF } \\
(.05-.10)\end{array}$ & $\begin{array}{c}F \\
(.10-.25)\end{array}$ & $\begin{array}{c}M \\
(.25-.50)\end{array}$ & $\begin{array}{c}C \\
(.5-1)\end{array}$ & $\begin{array}{c}\text { VC } \\
(1-2)\end{array}$ \\
\hline $0-15$ &. $\mathrm{~A}$ & 7.8 & 13.5 & 78.7 & 3.4 & 7.0 & 6.5 & 13.9 & 26.8 & 19.1 & 12.8 & 6.1 \\
\hline $15-33 \ldots$ & . Bt1 & 38.9 & 17.8 & 43.3 & 16.6 & 12.9 & 4.9 & 7.9 & 14.7 & 10.9 & 6.6 & 3.2 \\
\hline $33-56 \ldots$ & $\mathrm{Bt} 2$ & 55.0 & 18.4 & 26.6 & 24.0 & 15.0 & 3.4 & 4.9 & 8.0 & 6.0 & 5.1 & 2.6 \\
\hline $56-79 \ldots$ & $\mathrm{Bt} 2$ & 63.3 & 17.8 & 18.9 & 29.8 & 15.1 & 2.7 & 4.4 & 5.1 & 3.5 & 3.1 & 2.8 \\
\hline $79-104 \ldots$ &. $\mathrm{BC}$ & 47.4 & 25.8 & 26.8 & 20.4 & 21.6 & 4.2 & 6.5 & 7.7 & 4.9 & 4.1 & 3.6 \\
\hline $104-154 \ldots$ & $. \mathrm{B} / \mathrm{C}$ & 31.2 & 29.7 & 39.1 & 12.2 & 24.0 & 5.7 & 8.3 & 10.6 & 6.3 & 6.2 & 7.7 \\
\hline $154-216$. &. $\mathrm{Cl}$ & 19.4 & 33.0 & 47.6 & 6.9 & 26.6 & 6.4 & 13.3 & 17.4 & 5.6 & 5.3 & 6.0 \\
\hline $216-254$ & . 2 & 14.3 & 30.9 & 54.8 & 4.8 & 24.2 & 6.7 & 19.8 & 23.7 & 6.7 & 2.8 & 1.8 \\
\hline $254-304 \ldots$ &. $\mathrm{C} 3$ & 3.8 & 20.4 & 75.8 & 1.1 & 14.0 & 6.4 & 13.8 & 21.5 & 15.8 & 15.3 & 9.4 \\
\hline
\end{tabular}


Table 6C. Physical and chemical analyses of pedon S84GA-199-001

[Units of meaure for all values given in table 5. - , not detected; TR, trace]

\begin{tabular}{|c|c|c|c|c|c|c|c|c|c|c|c|c|c|}
\hline \multirow[b]{2}{*}{$\begin{array}{c}\text { Depth } \\
(\mathrm{cm})\end{array}$} & \multirow{2}{*}{\multicolumn{3}{|c|}{ Horizon }} & \multicolumn{5}{|c|}{ Dithionite-citrate } & \multicolumn{3}{|c|}{ Ratio clay } & \multirow{2}{*}{\multicolumn{2}{|c|}{$\begin{array}{c}\text { Bulk density } \\
\text { ( } 1 / 3 \text { bar) }\end{array}$}} \\
\hline & & & & \multicolumn{3}{|c|}{$\begin{array}{c}\text { Extractable } \\
\mathrm{Fe}\end{array}$} & \multicolumn{2}{|c|}{$\begin{array}{c}\text { Extractable } \\
\text { Al }\end{array}$} & $\mathrm{CEC}^{1}$ & \multicolumn{2}{|c|}{$15 \mathrm{bar}$} & & \\
\hline $0-15 \ldots \ldots$ & \multicolumn{3}{|c|}{$\mathrm{A}$} & \multicolumn{3}{|c|}{0.8} & \multicolumn{2}{|l|}{0.1} & 0.33 & \multicolumn{2}{|c|}{0.45} & \multicolumn{2}{|c|}{1.49} \\
\hline $15-33 \ldots \ldots$ & \multicolumn{3}{|c|}{ Bt1 } & \multicolumn{3}{|c|}{3.3} & \multicolumn{2}{|l|}{.3} & .12 & \multicolumn{2}{|c|}{.39} & \multicolumn{2}{|c|}{1.58} \\
\hline $33-56 \ldots \ldots$ & \multirow{2}{*}{\multicolumn{3}{|c|}{$\begin{array}{l}\mathrm{Bt} 2 \\
\mathrm{Bt} 2\end{array}$}} & \multicolumn{3}{|c|}{5.7} & \multicolumn{2}{|l|}{.4} & .10 & \multicolumn{2}{|c|}{.41} & \multicolumn{2}{|c|}{1.38} \\
\hline $56-79 \ldots \ldots$ & & & & \multicolumn{3}{|c|}{7.1} & \multicolumn{2}{|l|}{.5} & .12 & \multicolumn{2}{|c|}{.45} & \multicolumn{2}{|c|}{1.27} \\
\hline $79-104 \ldots$. & & \multicolumn{2}{|l|}{$\mathrm{BC}$} & \multicolumn{3}{|c|}{7.0} & \multicolumn{2}{|l|}{.5} & .11 & & 9 & & \\
\hline $104-154 \ldots$ & & $\mathrm{B} / \mathrm{C}$ & & & 6.8 & & .4 & & .13 & & 6 & & \\
\hline $154-216 \ldots$ & & $\mathrm{C} 1$ & & & 5.6 & & .3 & & .20 & & 1 & & \\
\hline $216-254 \ldots$ & & $\mathrm{C} 2$ & & & 3.9 & & .3 & & .26 & & 6 & & \\
\hline $254-304 \ldots \ldots$ & & $\mathrm{C} 3$ & & & .8 & & .1 & & .53 & & 7 & & \\
\hline & & & $\begin{array}{r}\mathrm{NH}_{4} \\
\text { tracta }\end{array}$ & $\begin{array}{l}\text { AC } \\
\text { le ba }\end{array}$ & & & & & $\mathrm{CEC}^{1}$ & & & $\mathrm{p}$ & \\
\hline $\begin{array}{l}\text { Depth } \\
(\mathrm{cm})\end{array}$ & Horizon & $\mathrm{Ca}$ & $\mathrm{Mg}$ & $\mathrm{Na}$ & $\mathrm{K}$ & Acidity & $\begin{array}{c}\text { Extractable } \\
\text { Al }\end{array}$ & $\begin{array}{l}\text { Sum of } \\
\text { cations }\end{array}$ & $\mathrm{NH}_{4} \mathrm{OAC}$ & Bases +Al & $\begin{array}{c}\mathrm{Al} \\
\text { saturation }\end{array}$ & $\begin{array}{l}\mathrm{CaCl}_{2} \\
(1: 2)\end{array}$ & $\begin{array}{l}\mathrm{H}_{2} \mathrm{O} \\
(1: 1)\end{array}$ \\
\hline $0-15$. & A & 0.1 & TR & TR & TR & 2.8 & 0.7 & 2.9 & 2.6 & 0.8 & 88 & 4.2 & 4.7 \\
\hline $15-33 \ldots \ldots$ & Bt1 & .5 & 0.3 & TR & TR & 4.5 & .8 & 5.3 & 4.5 & 1.6 & 50 & 4.5 & 5.1 \\
\hline $33-56 \ldots \ldots$ & Bt2 & .7 & .7 & TR & 0.1 & 6.6 & .6 & 8.1 & 5.6 & 2.1 & 29 & 4.6 & 5.2 \\
\hline $56-79 \ldots \ldots$ & Bt2 & .2 & .7 & TR & .1 & 8.8 & 1.1 & 9.8 & 7.5 & 2.1 & 52 & 4.5 & 5.2 \\
\hline 79-104 .... & $\mathrm{BC}$ & .1 & .3 & 0.1 & TR & 7.3 & 1.1 & 7.8 & 5.4 & 1.6 & 69 & 4.5 & 5.4 \\
\hline $104-154 \ldots$ & $\mathrm{B} / \mathrm{C}$ & TR & .2 & .1 & .1 & 6.2 & 1.1 & 6.6 & 4.2 & 1.5 & 73 & 4.6 & 5.4 \\
\hline $154-216 \ldots$ & $\mathrm{C} 1$ & - & .1 & TR & TR & 5.5 & 1.6 & 5.6 & 3.9 & 1.7 & 94 & 4.4 & 5.2 \\
\hline $216-254 \ldots$ & $\mathrm{C} 2$ & - & .1 & TR & TR & 4.7 & 1.7 & 4.8 & 3.7 & 1.8 & 94 & 4.3 & 5.1 \\
\hline $254-304 \ldots \ldots$ & C3 & - & .1 & TR & TR & 2.1 & .9 & 2.2 & 2.0 & 1.0 & 90 & 4.3 & 5.3 \\
\hline
\end{tabular}

${ }^{1}$ Cation exchange capacity.

Table 6D. Bulk chemistry of pedon S84GA-199-001

[All values in weight percent except for $\left(\mathrm{Fe}_{2} \mathrm{O}_{3}+\mathrm{Al}_{2} \mathrm{O}_{3}\right) / \mathrm{SiO}_{2}$, which is a ratio. No entry, no data]

\begin{tabular}{|c|c|c|c|c|c|c|c|c|}
\hline \multirow[b]{2}{*}{ Oxide } & \multicolumn{8}{|c|}{ Horizon $^{2}$} \\
\hline & $\begin{array}{c}\text { Bt1 } \\
(15-33)\end{array}$ & $\begin{array}{c}\text { Bt2 } \\
(33-56)\end{array}$ & $\begin{array}{c}B t 2 \\
(56-79)\end{array}$ & $\begin{array}{c}\text { BC } \\
(79-104)\end{array}$ & $\begin{array}{c}B / C \\
(104-154)\end{array}$ & $\begin{array}{c}C 1 \\
(154-216)\end{array}$ & $\begin{array}{c}C 2 \\
(216-254)\end{array}$ & $\begin{array}{c}\text { C3 } \\
(254-304)\end{array}$ \\
\hline $\mathrm{SiO}_{2} \ldots \ldots \ldots \ldots \ldots \ldots \ldots .59 .50$ & & & 76.80 & 49.50 & & 51.70 & & 67.10 \\
\hline $\mathrm{Al}_{2} \mathrm{O}_{3} \ldots \ldots \ldots \ldots \ldots \ldots \ldots .70$ & & & 9.00 & 25.60 & & 25.60 & & 18.50 \\
\hline $\mathrm{Fe}_{2} \mathrm{O}_{3} \ldots \ldots \ldots \ldots \ldots \ldots \ldots$ & & & 10.30 & 12.80 & & 4.60 & & 2.30 \\
\hline $\mathrm{CaO} \ldots \ldots \ldots \ldots \ldots \ldots \ldots \ldots \ldots \ldots \ldots$ & & & .11 & .10 & & .10 & & .11 \\
\hline $\mathrm{K}_{2} \mathrm{O} \ldots \ldots \ldots \ldots \ldots \ldots \ldots \ldots \ldots$ & & & .42 & .38 & & .21 & & 5.49 \\
\hline $\mathrm{TiO}_{2} \ldots \ldots \ldots \ldots \ldots \ldots \ldots .95$ & & & .48 & 1.05 & & 1.08 & & .35 \\
\hline $\mathrm{P}_{2} \mathrm{O}_{5} \ldots \ldots \ldots \ldots \ldots \ldots \ldots \ldots$ & & & .02 & .12 & & .14 & & .14 \\
\hline $\mathrm{MnO} \ldots \ldots \ldots \ldots \ldots \ldots \ldots$ & & & .03 & .04 & & .05 & & .03 \\
\hline $\mathrm{SO}_{2} \ldots \ldots \ldots \ldots \ldots \ldots \ldots \ldots$ & & & .08 & .08 & & .12 & & .06 \\
\hline Total $^{1} \ldots \ldots \ldots \ldots \ldots \ldots . \ldots 9.20$ & & & 97.20 & 89.80 & & 83.50 & & 94.00 \\
\hline$\left(\mathrm{Fe}_{2} \mathrm{O}_{3}+\mathrm{Al}_{2} \mathrm{O}_{3}\right) / \mathrm{SiO}_{2} \ldots \ldots \ldots . \quad .0770$ & & & .251 & .776 & & .584 & & .208 \\
\hline
\end{tabular}

${ }^{1}$ Totals significantly less than 100 percent are due to high $\mathrm{H}_{2} \mathrm{O}$ contents of clay-rich horizons. $\mathrm{H}_{2} \mathrm{O}$ not included in analyses.

${ }^{2}$ Depth in centimeters is given in parentheses. 
Table 6E. Observations on thin sections of pedon S84GA-199-001

\begin{tabular}{|c|c|c|}
\hline Horizon & $\begin{array}{l}\text { Depth } \\
(\mathrm{cm})\end{array}$ & Observations \\
\hline $\mathrm{Bt} 2$. & $33-56$ & $\begin{array}{l}\text { Clayey fabric is red-orange, oriented clay up to } 0.1 \mathrm{~mm} \text { thick along cracks, but thickness is mostly } 0.02 \text { to } 0.05 \\
\mathrm{~mm} \text {. Cannot get a good idea of internal porosity because of skips in the thin section. }\end{array}$ \\
\hline $\mathrm{BC}$ & 79-104 & Red, clayey fabric, oriented clay bodies scattered in a matrix along a few pores, all less than $0.1 \mathrm{~mm}$ thick. \\
\hline $\mathrm{C} 2$ & $216-254$ & $\begin{array}{l}\text { Thin section displays two distinct fabrics. The first is a uniform fabric of angular silt and sand grains and some } \\
\text { platy grains randomly oriented throughout. The second fabric is striking books of platy particles arrayed in } \\
\text { various "expanded accordion" fashion, mostly having low birefringence (kaolinite?) but some having high } \\
\text { birefringence (mica?). Several pictures were taken of the accordion books (see fig. 9). }\end{array}$ \\
\hline $\mathrm{C} 3$ & 254-304 & $\begin{array}{l}\text { Rock fragments of quartz, albite, and microcline. Some of the microcline appears to be albite in the center } \\
\text { rimmed with microcline. One grain having potassium feldspar cleavage gives an interference figure of } \\
\text { muscovite. Cracks among the rock fabrics contain brown clayey material, about } 10 \text { percent of the total thin } \\
\text { section. Pieces of platy grains having birefringence are scattered through the clayey material. }\end{array}$ \\
\hline
\end{tabular}

Table 7A. Field description of pedon S84GA-231-001

[Site 2, series not designated, $32^{\circ} 59^{\prime} 58^{\prime \prime}$ N., $84^{\circ} 19^{\prime} 24^{\prime \prime}$ W. Pike County, Ga., 1 km north of Upson County line on U.S. 19, 300 m E. of U.S. 19 above gravel pit. Parent material is Hollis Quartzite; surface elevation $310 \mathrm{~m}$ above mean sea level on a 6-percent southwest-facing upland slope. Vegetation dominantly pine. Site is well drained under a udic moisture regime. No entry, no data; - , none observed]

\begin{tabular}{|c|c|c|c|c|c|c|c|c|}
\hline $\begin{array}{c}\text { Depth } \\
(\mathrm{cm})\end{array}$ & Horizon & Moist color ${ }^{1}$ & Texture $^{2}$ & Structure $^{3}$ & Consistence $^{4}$ & Clay skins ${ }^{5}$ & Roots $^{6}$ & Boundary \\
\hline $0-20 \ldots \ldots \ldots \ldots$ & $\mathrm{A}$ & 10YR3/1 & gsl & $1 \mathrm{fgr}$ & vf & - & $\mathrm{ml}$ & cs \\
\hline $38-51 \ldots \ldots \ldots \ldots$ & $\mathrm{BE}$ & 10 YR6/6 & gsl & $1 \mathrm{fgr}$ & vf & - & $\mathrm{m} 12$ & $\mathrm{cW}$ \\
\hline $51-66 \quad \ldots \ldots \ldots \ldots$ & $2 \mathrm{Bt} 1$ & $2.5 Y R 5 / 8$ & $\mathrm{scl}$ & $2 \mathrm{msbk}$ & f & - & f1 & cs \\
\hline $66-85 \quad \ldots \ldots \ldots \ldots$ & $2 \mathrm{Bt} 2$ & $2.5 Y R 4 / 8$ & $\mathrm{cl}$ & $2 \mathrm{msbk}$ & f & $\mathrm{f}, \mathrm{t}$ & f1 & gw \\
\hline
\end{tabular}

\footnotetext{
${ }^{1}$ Munsell notation.

${ }^{2} \mathrm{cl}$, clay loam; g, gravelly; sl, sandy loam.

${ }^{3} 1$, weak; 2 , moderate; $f$, fine; $m$, medium; gr, granular; sbk, subangular blocky.

${ }^{4} \mathrm{f}$, friable; vf, very friable.

${ }^{5} \mathrm{f}$, faint; $\mathrm{t}$, thin.

${ }^{6} \mathrm{~m}$, many; $\mathrm{f}$, few; 1 , fine; 2 , medium.

${ }^{7} \mathrm{cs}$, clear smooth; cw, clear wavy; gw, gradual wavy; gs, gradual smooth; ai, abrupt irregular.
}

Table 7B. Textural analyses of horizons for pedon S84GA-231-001

[Sampled as fine, loamy, mixed, thermic Typic Hapludult. Grain sizes in millimeters; all other values in weight percent. VF, very fine; F, fine; M, medium; C, coarse; VC, very coarse]

\begin{tabular}{|c|c|c|c|c|c|c|c|c|c|c|c|c|}
\hline \multirow[b]{2}{*}{$\begin{array}{c}\text { Depth } \\
(\mathrm{cm})\end{array}$} & \multirow[b]{2}{*}{ Horizon } & \multicolumn{3}{|c|}{ Total } & \multirow{2}{*}{$\frac{\text { Clay }}{F}$} & \multicolumn{2}{|c|}{ Silt } & \multicolumn{5}{|c|}{ Sand } \\
\hline & & $\begin{array}{c}\text { Clay } \\
(<.002)\end{array}$ & $\begin{array}{c}\text { Silt } \\
(.002-.05)\end{array}$ & $\begin{array}{l}\text { Sand } \\
(.05-2)\end{array}$ & & $\begin{array}{c}F \\
(.002-.02)\end{array}$ & $\begin{array}{c}\mathrm{C} \\
(.02-.05)\end{array}$ & $\begin{array}{c}V F \\
(.05-.10)\end{array}$ & $\begin{array}{c}\mathrm{F} \\
(.10-.25)\end{array}$ & $\begin{array}{c}\mathrm{M} \\
(.25-.50)\end{array}$ & $\begin{array}{c}\mathrm{C} \\
(.5-1)\end{array}$ & $\begin{array}{l}\text { VC } \\
(1-2)\end{array}$ \\
\hline $0-20$ & $\mathrm{~A}$ & 6.7 & 18.3 & 75.0 & 2.0 & 12.1 & 6.2 & 9.7 & 24.0 & 20.9 & 11.8 & 8.6 \\
\hline $20-38 \ldots \ldots$ & $\mathrm{E}$ & 6.6 & 20.9 & 72.5 & 1.6 & 14.3 & 6.6 & 9.9 & 24.6 & 20.1 & 10.2 & 7.2 \\
\hline $38-51 \ldots \ldots$ & . $\mathrm{BE}$ & 9.2 & 20.6 & 70.2 & 2.2 & 14.7 & 5.9 & 8.7 & 21.0 & 16.0 & 10.3 & 14.2 \\
\hline $51-66$. & $2 \mathrm{Bt} 1$ & 27.8 & 20.6 & 51.6 & 7.9 & 15.8 & 4.8 & 6.6 & 14.2 & 11.0 & 8.8 & 11.0 \\
\hline 66-85. & . $2 \mathrm{Bt} 2$ & 49.8 & 15.8 & 34.4 & 14.6 & 12.4 & 3.4 & 4.7 & 11.1 & 10.6 & 5.4 & 2.6 \\
\hline $85-114 \ldots$ & - $2 \mathrm{Bt} 3$ & 59.1 & 10.0 & 30.9 & 21.6 & 7.1 & 2.9 & 4.0 & 8.5 & 8.9 & 6.0 & 3.5 \\
\hline $114-168 \ldots$ & $2 B t 4^{1}$ & 67.6 & 15.4 & 17.0 & 22.3 & 2.8 & 2.6 & 3.5 & 5.9 & 3.9 & 2.0 & 1.7 \\
\hline $168-220 \ldots$ & $2 \mathrm{Bt} 4^{1}$ & 60.4 & 17.4 & 22.2 & 15.1 & 4.0 & 3.4 & 4.2 & 8.4 & 6.1 & 2.7 & 0.8 \\
\hline $85-120 \ldots$ & $\begin{array}{c}(2 \mathrm{Bt} 3) \\
\mathrm{SAT}^{2}\end{array}$ & 54.7 & 8.6 & 36.7 & 21 & 5.6 & 3.0 & 3.8 & 11.6 & 13.2 & 6.8 & 1.3 \\
\hline
\end{tabular}

\footnotetext{
${ }^{1}$ Clay seams in the $2 \mathrm{Cr}$.

${ }^{2}$ Satellite sample of $2 \mathrm{Bt} 3$ taken about $2 \mathrm{~m}$ from principal pedon.
} 
Table 7C. Physical and chemical analyses of pedon S84GA-231-001

[Units of measure for all values given in table 5. No entry, no data; -, not detected; TR, trace]

\begin{tabular}{|c|c|c|c|c|c|c|c|c|c|c|c|c|c|c|}
\hline \multirow[b]{2}{*}{$\begin{array}{l}\text { Depth } \\
\text { (cm) }\end{array}$} & \multirow{2}{*}{\multicolumn{4}{|c|}{ Horizon }} & \multicolumn{5}{|c|}{ Dithionite-citrate } & \multicolumn{3}{|c|}{ Ratio clay } & \multirow{2}{*}{\multicolumn{2}{|c|}{$\begin{array}{c}\text { Bulk density } \\
\text { ( } 1 / 3 \text { bar })\end{array}$}} \\
\hline & & & & & \multicolumn{3}{|c|}{$\begin{array}{c}\text { Extractable } \\
\text { Fe }\end{array}$} & \multicolumn{2}{|c|}{$\begin{array}{c}\text { Extractable } \\
\qquad \mathrm{AI}\end{array}$} & $\mathrm{CEC}^{2}$ & \multicolumn{2}{|c|}{15 bar } & & \\
\hline $0-20$. & \multicolumn{4}{|c|}{$\mathrm{A}$} & \multicolumn{3}{|c|}{0.3} & \multicolumn{2}{|l|}{0.2} & 2.04 & \multicolumn{2}{|c|}{1.00} & \multicolumn{2}{|c|}{1.30} \\
\hline $20-38 \ldots \ldots$ & \multicolumn{4}{|c|}{$\mathrm{E}$} & \multicolumn{3}{|c|}{.3} & \multicolumn{2}{|l|}{.1} & .35 & \multicolumn{2}{|c|}{.41} & \multicolumn{2}{|c|}{1.30} \\
\hline $38-51 \ldots \ldots$ & \multicolumn{4}{|c|}{$\mathrm{BE}$} & \multicolumn{3}{|c|}{.4} & \multicolumn{2}{|l|}{.1} & .21 & \multicolumn{2}{|c|}{.34} & \multicolumn{2}{|c|}{1.30} \\
\hline $51-66 \ldots \ldots$ & \multicolumn{4}{|c|}{$2 \mathrm{Bt} 1$} & \multicolumn{3}{|c|}{1.3} & \multicolumn{2}{|l|}{.2} & .17 & \multicolumn{2}{|c|}{.33} & \multicolumn{2}{|c|}{1.60} \\
\hline $66-85 \ldots \ldots$ & \multicolumn{4}{|c|}{$2 \mathrm{Bt} 2$} & \multicolumn{3}{|c|}{3.1} & \multicolumn{2}{|l|}{.3} & .14 & & 5 & 1.4 & \\
\hline $85-114 \ldots \ldots$ & & $2 \mathrm{Bt} 3$ & & & & 4.6 & & .4 & & .13 & & 6 & 1.4 & \\
\hline $114-168 \ldots$ & & $2 \mathrm{Bt} 4$ & & & & 5.0 & & .4 & & .12 & & 6 & 1.4 & \\
\hline $168-220 \ldots$ & & $2 \mathrm{Bt} 4$ & & & & 4.4 & & .3 & & .11 & & 7 & 1.5 & \\
\hline $85-120 \ldots \ldots$ & & $(2 \mathrm{Bt} 3$ & SAT & & & 4.0 & & .4 & & .13 & & 6 & & \\
\hline & & & & $\begin{array}{r}\mathrm{NH}_{4} \\
\text { tracta } \\
\end{array}$ & $\begin{array}{l}\mathrm{AC} \\
\mathrm{ba}\end{array}$ & & & & & $\mathrm{CEC}^{2}$ & & & $\mathrm{pl}$ & \\
\hline $\begin{array}{c}\text { Depth } \\
(\mathrm{cm})\end{array}$ & Horiz & & $\mathrm{Ca}$ & $\mathrm{Mg}$ & $\mathrm{Na}$ & $\mathrm{K}$ & Acidity & $\begin{array}{c}\text { Extractable } \\
\mathrm{Al}\end{array}$ & $\begin{array}{l}\text { Sum of } \\
\text { cations }\end{array}$ & $\mathrm{NH}_{4} \mathrm{OAC}$ & Bases +Al & $\begin{array}{c}\mathrm{Al} \\
\text { saturation }\end{array}$ & $\begin{array}{l}\mathrm{CaCl}_{2} \\
(1: 2)\end{array}$ & $\begin{array}{l}\mathrm{H}_{2} \mathrm{O} \\
(1: 1)\end{array}$ \\
\hline $0-20 \ldots \ldots$ & A & & 1.8 & 0.3 & 0.1 & 0.1 & 14.1 & 1.9 & 16.4 & 13.7 & 4.2 & 45 & 4.2 & 4.9 \\
\hline $20-38 \ldots \ldots$ & $\mathrm{E}$ & & .1 & TR & TR & - & 2.4 & .4 & 2.5 & 2.3 & .5 & 80 & 4.8 & 5.0 \\
\hline $38-51 \ldots \ldots$ & $\mathrm{BE}$ & & .1 & $\mathrm{TR}$ & $\mathrm{TR}$ & - & 2.4 & .4 & 2.5 & 1.9 & .5 & 80 & 4.4 & 4.8 \\
\hline $51-66 \ldots \ldots$ & $2 \mathrm{Bt} 1$ & & .1 & .3 & TR & TR & 4.4 & 1.2 & 4.8 & 4.8 & 1.6 & 75 & 4.2 & 4.7 \\
\hline $66-85 \ldots \ldots$ & $2 \mathrm{Bt} 2$ & & .1 & .6 & TR & $\mathrm{TR}$ & 6.7 & 1.7 & 7.4 & 6.8 & 2.4 & 71 & 4.2 & 4.8 \\
\hline $85-114 \ldots \ldots$ & $2 \mathrm{Bt} 3$ & & .1 & .5 & TR & TR & 7.5 & 2.1 & 8.1 & 7.9 & 2.7 & 78 & 4.3 & 4.8 \\
\hline $114-168 \ldots$ & $2 \mathrm{Bt} 4$ & & TR & .2 & $\mathrm{TR}$ & $\mathrm{TR}$ & 8.0 & 3.3 & 8.2 & 7.9 & 3.5 & 94 & 4.2 & 4.7 \\
\hline $168-220 \ldots$ & $2 \mathrm{Bt} 4$ & & .2 & .1 & TR & - & 7.5 & 3.4 & 7.8 & 6.5 & 3.7 & 92 & 4.2 & 4.7 \\
\hline $85-120 \ldots \ldots$ & $(2 \mathrm{Bt} 3) \mathrm{S}$ & $\mathrm{AT}^{1}$ & .2 & .7 & TR & .2 & 7.7 & 1.7 & 8.8 & 7.1 & 2.8 & 61 & 4.3 & 4.9 \\
\hline
\end{tabular}

${ }^{1}$ Satellite sample of $2 \mathrm{Bt} 3$ taken about $2 \mathrm{~m}$ from principal pedon.

${ }^{2}$ Cation exchange capacity.

Table 7D. Bulk chemistry of pedon S84GA-231-001

[All values in weight percent except for $\left(\mathrm{Fe}_{2} \mathrm{O}_{3}+\mathrm{Al}_{2} \mathrm{O}_{3}\right) / \mathrm{SiO}_{2}$, which is a ratio. No entry, no data]

\begin{tabular}{|c|c|c|c|c|c|c|c|c|}
\hline & \multicolumn{8}{|c|}{ Horizon $^{2}$} \\
\hline & $\underset{(0-20)}{A}$ & $\begin{array}{c}E \\
(20-38)\end{array}$ & $\begin{array}{c}\text { BE } \\
(38-51)\end{array}$ & $\begin{array}{c}2 \mathrm{Bt1} \\
(51-66)\end{array}$ & $\begin{array}{c}2 \mathrm{Bt} 2 \\
(66-85)\end{array}$ & $\begin{array}{c}2 \mathrm{~B}+3 \\
(85-114)\end{array}$ & $\begin{array}{c}2 \mathrm{Bt4} \\
(114-168)\end{array}$ & $\begin{array}{c}2 \mathrm{Bt} 4) \\
(168-220)\end{array}$ \\
\hline $\mathrm{SiO}_{2}$. & $\ldots$. & $\ldots \ldots$ & 90.18 & & 58.85 & 52.72 & 46.67 & 50.65 \\
\hline $\mathrm{Al}_{2} \mathrm{O}_{3}$ & $\ldots \ldots$ & $\ldots \ldots$ & 6.16 & & 23.41 & 26.19 & 30.51 & 28.71 \\
\hline $\mathrm{Fe}_{2} \mathrm{O}_{3}$ & $\ldots .$. & $\ldots \ldots$ & .64 & & 5.66 & 7.99 & 8.85 & 7.56 \\
\hline $\mathrm{CaO}$. & ( & $\ldots \ldots$ & .12 & & .11 & .11 & .11 & .10 \\
\hline $\mathrm{K}_{2} \mathrm{O}$. . & $\ldots \ldots$ & $\ldots \ldots$ & .46 & & 1.23 & 1.17 & 1.14 & 1.14 \\
\hline $\mathrm{TiO}_{2}$. & $\ldots \ldots$ & $\ldots \ldots$ & .73 & & 1.19 & 1.28 & 1.31 & 1.17 \\
\hline $\mathrm{P}_{2} \mathrm{O}_{5}$. & $\ldots \ldots$ & $\ldots \ldots$ & .07 & & .08 & .06 & .09 & .08 \\
\hline $\mathrm{MnO}$. & & & .02 & & .03 & .02 & .03 & .03 \\
\hline $\mathrm{SO}_{2} \ldots$ & & & .06 & & .09 & .08 & .07 & .09 \\
\hline Total $^{1}$ & & $\cdots$ & 98.44 & & 90.66 & 89.65 & 88.79 & 89.54 \\
\hline$\left(\mathrm{Fe}_{2} \mathrm{O}\right.$ & & & .08 & & .49 & .65 & .84 & .72 \\
\hline
\end{tabular}

${ }^{1}$ Totals significantly less than 100 percent are due to high $\mathrm{H}_{2} \mathrm{O}$ contents of clay-rich horizons. $\mathrm{H}_{2} \mathrm{O}$ not included in analyses.

${ }^{2}$ Depths in centimeters are given in parentheses. 
Table 8A. Field description of pedon S84GA-231-003

[Site 3, series not designated, $32^{\circ} 00^{\prime} 11^{\prime \prime}$ N., $84^{\circ} 20^{\prime} 58^{\prime \prime}$ W. Pike County, Ga., $2 \mathrm{~km}$ west of U.S. $19 ; 2 \mathrm{~km}$ south on mountain road; Zebulon 7.5 -min quadrangle. Parent material is residuum from the Hollis Quartzite; surface elevation $342 \mathrm{~m}$ above mean sea level on a 5-percent northeast-facing upland slope. Vegetation dominantly pine. Site is well drained under a udic moisture regime. No entry, no data; - , not detected]

\begin{tabular}{|c|c|c|c|c|c|c|c|c|}
\hline $\begin{array}{l}\text { Depth } \\
\text { (cm) }\end{array}$ & Horizon $^{1}$ & Moist color ${ }^{2}$ & Texture $^{3}$ & Structure ${ }^{4}$ & Consistence $^{5}$ & Clay skins & Roots $^{6}$ & Boundary \\
\hline $0-10 \ldots \ldots \ldots \ldots$ & Al & $10 Y R 5 / 3$ & gsl & If $\mathrm{gr}$ & vf & - & $\mathrm{m} 12 \mathrm{f} 3$ & cs \\
\hline $10-33 \ldots \ldots \ldots \ldots$ & $\mathrm{A} 2$ & $10 Y R 5 / 4$ & gsl & If gr & vf & - & $\mathrm{m} 12 \mathrm{f} 3$ & $\mathrm{cw}$ \\
\hline $33-53 \ldots \ldots \ldots \ldots$ & $\mathrm{AB}$ & 10YR $5 / 6$ & gsl & If $\mathrm{gr}$ & vf & - & $\mathrm{m} 12 \mathrm{f} 3$ & $\mathrm{cw}$ \\
\hline $53-71 \ldots \ldots \ldots \ldots$ & $\mathrm{B} / \mathrm{C}$ & 10 YR $5 / 6$ & $\mathrm{scl}$ & $2 \mathrm{~m} \mathrm{sbk}$ & f & - & $\mathrm{f} 1$ & as \\
\hline $71-87 \ldots \ldots \ldots \ldots$ & $\mathrm{C} 1$ & $2.5 \mathrm{YR} 4 / 8$ & sl & $\mathrm{M}$ & vfi & & & aw \\
\hline $87-114 \ldots \ldots \ldots \ldots$ & $\mathrm{C} 2$ & $\begin{array}{l}2.5 \text { YR } 4 / 8 \\
7.5 \text { YR } 5 / 8\end{array}$ & $\mathrm{u}$ & $\mathbf{M}$ & $\mathrm{h}$ & & & aw \\
\hline $114-138 \ldots \ldots \ldots$ & C3 & $2.5 \mathrm{YR} 4 / 8$ & fsl & $\mathbf{M}$ & f & & f1 & aw \\
\hline $138-150 \ldots \ldots \ldots$ & $\mathrm{C} 4$ & & $\mathbf{u}$ & $\mathrm{M}$ & $\mathrm{h}$ & & & aw \\
\hline $150-178 \ldots \ldots \ldots$ & $\mathrm{C} 5$ & & $\mathbf{u}$ & $\mathbf{M}$ & f & & & aw \\
\hline $178-191 \ldots \ldots \ldots$ & C6 & & u & M & $\mathrm{h}$ & & & aw \\
\hline $191-204 \ldots \ldots \ldots$ & C7 & & $\mathbf{u}$ & & f & & & aw \\
\hline $204-221 \ldots \ldots \ldots \ldots$ & C8 & & $\mathbf{u}$ & & f & & & aw \\
\hline $221-230 \ldots \ldots \ldots$ & $\mathrm{C} 9$ & & $\mathbf{u}$ & & f & & & aw \\
\hline
\end{tabular}

${ }^{1} \mathrm{~A} 1$, common fine and medium gravel, few coarse gravel; A2, common fine and medium gravel, few coarse gravel; AB, few fine, medium, and coarse gravel; $\mathrm{B} / \mathrm{C}$, few fine gravel, 30 percent highly weathered fragments of quartzite; $\mathrm{C} 1$, quartzite saprolite that crushes to sandy loam; $\mathrm{C} 2$, quartzite saprolite and seams of strong brown clay loam; $\mathrm{C} 3$, mica schist saprolite that crushes to fine sandy loam; 4 , quartzite saprolite; C5, mica schist saprolite; $\mathrm{C} 6$, quartzite saprolite; $\mathrm{C}$, mica schist saprolite; $\mathrm{C} 8$, quartzite saprolite; $\mathrm{C} 9$, mica schist saprolite.

${ }^{2}$ Munsell notation.

${ }^{3}$ fsl, fine sandy loam; gsl, gravelly sandy loam; sl, sandy loam; scl, sandy clay loam; cl, clay loam; u, undetermined.

${ }^{4} 1$, weak; 2 , moderate; $f$, fine; $m$, medium; gr, granular; sbk, subangular blocky; $M$, massive.

${ }^{5}$ f, friable; vf, very friable; $h$, hard; fi, firm; vfi, very firm.

${ }^{6} \mathrm{~m}$, many; $\mathrm{f}$, few; 1 , fine; 2 , medium; 3 , large.

${ }^{7}$ as, abrupt smooth; cs, clear smooth; cw, clear wavy; aw, abrupt wavy.

Table 8B. Textural analyses of horizons for pedon S84GA-231-003

[Grain sizes in millimeters; all other values in weight percent; VF, very fine; F, fine; M, medium; C, coarse; VC, very coarse. No entry, no data]

\begin{tabular}{|c|c|c|c|c|c|c|c|c|c|c|c|c|}
\hline \multirow[b]{2}{*}{$\begin{array}{l}\text { Depth } \\
(\mathrm{cm})\end{array}$} & \multirow[b]{2}{*}{ Horizon } & \multicolumn{3}{|c|}{ Total } & \multirow{2}{*}{$\frac{\text { Clay }}{\mathrm{F}}$} & \multicolumn{2}{|c|}{ Silt } & \multicolumn{5}{|c|}{ Sand } \\
\hline & & $\begin{array}{c}\text { Clay } \\
(<.002)\end{array}$ & $\begin{array}{c}\text { Silt } \\
(.002-.05)\end{array}$ & $\begin{array}{l}\text { Sand } \\
(.05-2)\end{array}$ & & $\begin{array}{c}F \\
(.002-.02)\end{array}$ & $\begin{array}{c}\mathrm{C} \\
(.02-.05)\end{array}$ & $\begin{array}{c}V F \\
(.05-.10)\end{array}$ & $\begin{array}{c}\mathrm{F} \\
(.10-.25)\end{array}$ & $\begin{array}{c}M \\
(.25-.50)\end{array}$ & $\begin{array}{c}C \\
(.5-1)\end{array}$ & $\begin{array}{c}\text { VC } \\
(1-2)\end{array}$ \\
\hline $0-10$ & $\mathrm{~A} 1$ & 9.8 & 17.8 & 72.4 & & 12.5 & 5.3 & 6.4 & 19.3 & 20.9 & 14.5 & 11.3 \\
\hline $10-33$ & A2 & 9.5 & 18.5 & 72.0 & & 13.0 & 5.5 & 6.6 & 20.0 & 21.5 & 15.1 & 8.8 \\
\hline $33-53$ & $\mathrm{AB}$ & 18.1 & 19.5 & 62.4 & & 14.3 & 5.2 & 5.5 & 15.7 & 18.6 & 13.2 & 9.4 \\
\hline $53-71 \ldots$ & . $\mathrm{B} / \mathrm{C}$ & 18.4 & 12.2 & 69.4 & & 8.4 & 3.8 & 5.0 & 15.7 & 22.4 & 16.9 & 9.4 \\
\hline $71-87 \ldots$ & . $\mathrm{C} 1$ & 16.6 & 10.1 & 73.3 & & 6.1 & 4.0 & 6.8 & 22.1 & 28.5 & 13.5 & 2.4 \\
\hline $87-114 \ldots$ & . $\mathrm{C} 2$ & 7.2 & 6.8 & 86.0 & & 2.3 & 4.5 & 8.9 & 26.1 & 30.7 & 15.2 & 5.1 \\
\hline $114-138 \ldots$ & . $\mathrm{C} 3$ & 23.9 & 21.4 & 54.7 & & 17.6 & 3.8 & 5.9 & 16.7 & 16.2 & 11.5 & 4.4 \\
\hline $138-150 \ldots$ & . $\mathrm{C} 4$ & 8.4 & 19.4 & 72.2 & & 12.4 & 7.0 & 9.9 & 19.5 & 18.9 & 15.8 & 8.1 \\
\hline $150-178 \ldots$ & . C5 & 3.3 & 20.1 & 76.6 & & 12.3 & 7.8 & 10.2 & 18.0 & 19.9 & 18.4 & 10.1 \\
\hline $178-191 \ldots$ & . C6 & 1.5 & 9.7 & 88.8 & & 4.2 & 5.5 & 10.0 & 26.3 & 28.1 & 16.2 & 8.2 \\
\hline $191-204 \ldots$ & . $\mathrm{C} 7$ & 11.5 & 26.1 & 62.4 & & 21.7 & 4.4 & 7.2 & 23.7 & 20.8 & 8.1 & 2.6 \\
\hline $204-221 \ldots$ & . $\mathrm{C} 8$ & 1.8 & 9.4 & 88.8 & & 5.9 & 3.5 & 7.8 & 27.5 & 32.6 & 16.3 & 4.6 \\
\hline
\end{tabular}


Table 8C. Physical and chemical analyses of pedon S84GA-231-003

[Units of measure for all values given in table 5 . No entry, no data; - , not detected; TR, trace]

\begin{tabular}{|c|c|c|c|c|c|c|c|c|c|c|c|c|c|}
\hline \multirow[b]{2}{*}{$\begin{array}{l}\text { Depth } \\
(\mathrm{cm})\end{array}$} & \multirow{2}{*}{\multicolumn{2}{|c|}{ Horizon }} & \multicolumn{5}{|c|}{ Dithionite-citrate } & \multicolumn{2}{|c|}{ Ratio clay } & \multirow{2}{*}{\multicolumn{2}{|c|}{$\begin{array}{l}\text { Water content } \\
\left(^{(15} \text { bar }\right)^{2}\end{array}$}} & \multirow{2}{*}{\multicolumn{2}{|c|}{$\begin{array}{c}\text { Bulk density } \\
\text { (1/3 bar) }\end{array}$}} \\
\hline & & & \multicolumn{3}{|c|}{$\begin{array}{l}\text { Extractable } \\
\text { Fe }\end{array}$} & \multicolumn{2}{|c|}{$\begin{array}{c}\text { Extractable } \\
\qquad \mathrm{Al}\end{array}$} & $\mathrm{CEC}^{1}$ & 15 bar & & & & \\
\hline $0-10 \ldots \ldots$ & \multicolumn{2}{|c|}{$\mathrm{A} 1$} & \multicolumn{3}{|c|}{0.4} & \multicolumn{2}{|c|}{0.2} & 0.57 & 0.56 & \multicolumn{2}{|c|}{5.5} & \multicolumn{2}{|c|}{1.91} \\
\hline $10-33 \ldots \ldots$ & \multicolumn{2}{|c|}{$\mathrm{A} 2$} & \multicolumn{3}{|c|}{.4} & \multicolumn{2}{|c|}{.1} & .24 & .33 & \multicolumn{2}{|c|}{3.1} & \multicolumn{2}{|c|}{1.76} \\
\hline $33-53 \ldots \ldots$ & \multirow{2}{*}{\multicolumn{2}{|c|}{$\begin{array}{l}\mathrm{AB} \\
\mathrm{B} / \mathrm{C}\end{array}$}} & \multicolumn{3}{|c|}{.9} & \multicolumn{2}{|c|}{.2} & .18 & .30 & \multicolumn{2}{|c|}{5.5} & \multicolumn{2}{|c|}{1.8} \\
\hline $53-71 \ldots \ldots$ & & & & 1.1 & & 2 & & .13 & .34 & 6. & & 1. & \\
\hline $71-87 \ldots \ldots$ & $\mathrm{C} 1$ & & & 1.3 & & .2 & & .10 & .42 & 7. & & 1. & \\
\hline $87-114 \ldots \ldots$ & $\mathrm{C} 2$ & & & .5 & & . & & .07 & .39 & 2. & & 1.2 & \\
\hline $114-138 \ldots$ & $\mathrm{C} 3$ & & & 3.4 & &. & & .14 & .43 & 10 . & & 1.4 & \\
\hline $138-150 \ldots$ & $\mathrm{C} 4$ & & & 1.2 & &. & & .07 & .50 & 4. & & 1.4 & \\
\hline $150-178 \ldots$ & C5 & & & .9 & & .1 & & .03 & .79 & 2. & & 1.4 & \\
\hline $178-191 \ldots$ & C6 & & & .1 & & TR & & - & .47 & & 7 & 1. & \\
\hline $191-204 \ldots$. & C7 & & & 1.7 & & . & & .23 & .51 & 5. & & 1.4 & \\
\hline $204-221 \ldots$. & $\mathrm{C} 8$ & & & .3 & & TF & & - & .78 & 1. & & 1.4 & \\
\hline $221-230 \ldots$ & C9 & & & 1.3 & & . & & .20 & .54 & 3. & & 1.2 & \\
\hline & & & $\begin{array}{l}\mathrm{NH} \\
\text { act }\end{array}$ & $\begin{array}{l}\mathrm{AC} \\
\text { bas }\end{array}$ & & & & & $\mathrm{CEC}^{1}$ & & & $\mathrm{pr}$ & \\
\hline $\begin{array}{c}\text { Depth } \\
(\mathrm{cm})\end{array}$ & Horizon & $\mathrm{Ca}$ & $\mathrm{Mg}$ & $\mathrm{Na}$ & K & Acidity & $\begin{array}{c}\text { Extractable } \\
\text { Al }\end{array}$ & $\begin{array}{l}\text { Sum of } \\
\text { cations }\end{array}$ & $\mathrm{NH}_{4} \mathrm{OAC}$ & Bases $+\mathrm{Al}$ & $\begin{array}{c}\mathrm{Al} \\
\text { saturation }\end{array}$ & $\begin{array}{c}\mathrm{CaCl}_{2} \\
(1: 2) \\
\end{array}$ & $\begin{array}{l}\mathrm{H}_{2} \mathrm{O} \\
(1: 1) \\
\end{array}$ \\
\hline $0-10 \ldots \ldots$ & A1 & 0.1 & 0.2 & TR & 0.1 & 6.7 & .8 & 7.1 & 5.6 & 1.2 & 67 & 4.6 & 5.1 \\
\hline $10-33 \ldots \ldots$ & $\mathrm{A} 2$ & .1 & TR & TR & TR & 2.7 & .5 & 2.8 & 2.3 & .6 & 83 & 4.4 & 4.7 \\
\hline $33-53 \ldots \ldots$ & $A B$ & .1 & .1 & TR & TR & 2.8 & .7 & 3.0 & 3.3 & .9 & 78 & 4.3 & 4.8 \\
\hline $53-71 \ldots \ldots$ & $\mathrm{B} / \mathrm{C}$ & .3 & .4 & TR & $\mathrm{TR}$ & 1.9 & .3 & 2.6 & 2.4 & 1.0 & 30 & 4.6 & 5.2 \\
\hline $71-87 \ldots \ldots$ & $\mathrm{Cl}$ & TR & .3 & TR & TR & 3.9 & .4 & 4.2 & 1.6 & .7 & 57 & 4.5 & 5.0 \\
\hline $87-114 \ldots \ldots$ & $\mathrm{C} 2$ & TR & .1 & TR & TR & 1.2 & .2 & 1.3 & .5 & .3 & 67 & 4.6 & 5.0 \\
\hline $114-138 \ldots$ & $\mathrm{C} 3$ & TR & .2 & - & .1 & 3.8 & .0 & 4.1 & 3.4 & 1.3 & 77 & 4.4 & 5.0 \\
\hline $138-150 \ldots$ & $\mathrm{C} 4$ & - & .1 & .1 & - & 1.2 & .4 & 1.4 & .6 & .6 & 67 & 4.5 & 4.9 \\
\hline $150-178 \ldots$ & $\mathrm{C} 5$ & - & TR & .1 & TR & .8 & .4 & .9 & .1 & .5 & 80 & 4.5 & 4.8 \\
\hline $178-191 \ldots$ & C6 & - & $\mathrm{TR}$ & TR & - & - & .1 & & TR & .1 & 100 & 4.9 & 5.4 \\
\hline $191-204 \ldots$. & $\mathrm{C7}$ & - & TR & TR & - & 3.0 & .2 & 3.0 & 2.6 & 1.2 & 100 & 4.3 & 4.6 \\
\hline $204-221 \ldots$ & $\mathrm{C} 8$ & & - & TR & - & .5 & .2 & .5 & TR & .2 & 100 & 4.5 & 4.8 \\
\hline $221-230 \ldots$ & $\mathrm{C} 9$ & & $\mathrm{TR}$ & .1 & - & 2.2 & .6 & 2.3 & 1.3 & .7 & 86 & 4.3 & 4.7 \\
\hline
\end{tabular}

${ }^{1}$ Cation exchange capacity.

${ }^{2}$ Water content at 15 -bar pressure. 
Table 9A. Field description of pedon S84GA-231-004

[Site 4, series not designated, $30^{\circ} 00^{\prime} 09^{\prime \prime}$ N., $84^{\circ} 20^{\prime} 57^{\prime \prime}$ W. Pike County, Ga., $2 \mathrm{~km}$ west of U.S. 19 on Oliver Road, $2 \mathrm{~km}$ south on mountain road; Zebulon 7.5-min quadrangle. Parent material is weathered Hollis Quartzite; surface elevation is $345 \mathrm{~m}$ above mean sea level on a 7-percent northeast-facing upland slope. Vegetation dominantly pine forest. Site is well drained under a udic moisture regime. No entry, no data; - , not observed]

\begin{tabular}{|c|c|c|c|c|c|c|c|}
\hline $\begin{array}{l}\text { Depth } \\
(\mathrm{cm})\end{array}$ & Horizon $^{1}$ & Moist color ${ }^{2}$ & Texture $^{3}$ & Structure $^{4}$ & Consistence $^{5}$ & Roots $^{6}$ & Boundary ${ }^{7}$ \\
\hline $0-13 \ldots \ldots \ldots \ldots$ & A & $10 Y R 4 / 3$ & sl & If $\mathrm{gr}$ & vf & $\mathrm{m} 12$ & $\mathrm{cs}$ \\
\hline $13-38 \ldots \ldots \ldots \ldots$ & $\mathrm{E}$ & 10YR 5/4 & sl & If $\mathrm{gr}$ & vf & $\mathrm{m} 12$ & cs \\
\hline $38-61 \ldots$ & BA & 7.5 YR 5/8 & $\mathrm{scl}$ & $1 \mathrm{~m} \mathrm{sbk}$ & f & $\operatorname{cl~f2}$ & cs \\
\hline $61-91 \ldots \ldots \ldots \ldots$ & Bt1 & $5 Y R 5 / 8$ & scl & $2 \mathrm{~m}$ sbk & f & $\mathrm{c} 12$ & $\mathrm{cs}$ \\
\hline $91-117 \ldots \ldots \ldots \ldots$ & $\mathrm{Bt} 2$ & $5 Y R 5 / 8$ & $\mathrm{scl}$ & $2 \mathrm{~m} \mathrm{pl} / 2 \mathrm{~m} \mathrm{abk}$ & $\mathrm{f}$ & $\mathrm{fl}$ & cs \\
\hline $117-145 \ldots \ldots \ldots$ & $\mathrm{Bt} 3$ & $\begin{array}{l}\text { 10R } 4 / 6 \\
\text { 10YR } 5 / 8\end{array}$ & $\mathrm{cl}$ & $2 \mathrm{~m}$ abk/0 sbk & fi & - & aw \\
\hline $145-168 \ldots \ldots \ldots$ & $\mathrm{B} / \mathrm{C}$ & $10 \mathrm{R} 4 / 6$ & 1 & $\mathbf{M}$ & fi & - & aw \\
\hline $168-183 \ldots \ldots \ldots$ & $\mathrm{Cr}$ & & & $\mathbf{M}$ & & & \\
\hline
\end{tabular}

${ }^{1} \mathrm{~A}$, few fine and medium gravel; E, common fine and medium gravel; BA, common fine and medium gravel; Bt1, common fine and medium gravel; Bt2, few fine gravel; Bt3, few fine gravel, red and yellowish-brown colors in horizontal bands about $3 \mathrm{~cm}$ thick (red portion slightly brittle); B/C, pockets of quartzite (20 percent by volume); Cr, quartzite saprolite, discontinuous red clay bands 7 to $25 \mathrm{~mm}$ thick, hard in place.

${ }^{2}$ Munsell notation.

${ }^{3}$ l, loam; sl, sandy loam; cl, clay loam; scl, sandy clay loam.

${ }^{4} 0$, very weak; 1 , weak; 2 , moderate; f, fine; m, medium; gr, granular; abk, angular blocky; sbk, subangular blocky; P, platy; M, massive; /, breaking to.

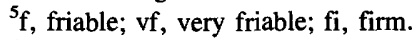

${ }^{6} \mathrm{~m}$, many; 1 , fine; 2 , medium; c, common; $\mathrm{f}$, few.

${ }^{7} \mathrm{cs}$, clear smooth; aw, abrupt wavy.

Table 9B. Textural analyses of horizons for pedon S84GA-231-004

[Sampled as fine, loamy, mixed, thermic Typic Hapludult. Grain sizes in millimeters; all other values in weight percent. VF, very fine; F, fine; M, medium; $\mathrm{C}$, coarse; VC, very coarse]

\begin{tabular}{|c|c|c|c|c|c|c|c|c|c|c|c|c|}
\hline \multirow[b]{2}{*}{$\begin{array}{l}\text { Depth } \\
\text { (cm) }\end{array}$} & \multirow[b]{2}{*}{ Horizon } & \multicolumn{3}{|c|}{ Total } & \multirow{2}{*}{$\frac{\text { Clay }}{F}$} & \multicolumn{2}{|c|}{ Silt } & \multicolumn{5}{|c|}{ Sand } \\
\hline & & $\begin{array}{c}\text { Clay } \\
(<.002)\end{array}$ & $\begin{array}{c}\text { Silt } \\
(.002-.05)\end{array}$ & $\begin{array}{c}\text { Sand } \\
(.05-2)\end{array}$ & & $\begin{array}{c}F \\
(.002-.02)\end{array}$ & $\begin{array}{c}\mathrm{C} \\
(.02-.05)\end{array}$ & $\begin{array}{c}\text { VF } \\
(.05-.10)\end{array}$ & $\begin{array}{c}\mathrm{F} \\
(.10-.25)\end{array}$ & $\begin{array}{c}M \\
(.25-.50)\end{array}$ & $\begin{array}{c}\mathrm{C} \\
(.5-1)\end{array}$ & $\begin{array}{c}\text { VC } \\
(1-2)\end{array}$ \\
\hline $0-13$ & A & 8.0 & 19.5 & 72.5 & 3.2 & 13.7 & 5.8 & 6.2 & 22.6 & 27.4 & 13.2 & 3.1 \\
\hline $13-38$ & . $\mathrm{E}$ & 7.5 & 17.1 & 75.4 & 2.8 & 13.5 & 3.6 & 6.8 & 23.9 & 27.7 & 13.1 & 3.9 \\
\hline $38-61 \ldots$ & . $\mathrm{BA}$ & 22.5 & 14.4 & 63.1 & 11.1 & 11.5 & 2.9 & 5.2 & 19.5 & 21.3 & 13.4 & 3.7 \\
\hline $61-91 \ldots$ & . $\mathrm{Bt} 1$ & 45.5 & 10.2 & 44.3 & 26.1 & 7.6 & 2.6 & 4.0 & 13.1 & 15.1 & 9.4 & 2.7 \\
\hline $91-117 \ldots$ & . $\mathrm{Bt} 2$ & 54.2 & 12.8 & 33.0 & 25.2 & 9.1 & 3.7 & 4.2 & 8.8 & 10.8 & 6.6 & 2.6 \\
\hline $117-145 \ldots$ & . $\mathrm{Bt} 3$ & 54.9 & 15.9 & 29.2 & 23.4 & 11.6 & 4.3 & 4.8 & 7.7 & 8.7 & 5.6 & 2.4 \\
\hline $145-168 \ldots$ & . $\mathrm{B} / \mathrm{C}$ & 46.4 & 15.8 & 37.8 & 17.6 & 12.9 & 2.9 & 5.5 & 25.2 & .5 & 5.5 & 1.1 \\
\hline $168-183 \ldots$ & . $\mathrm{Cr}$ & 15.8 & 6.9 & 77.3 & 6.0 & 4.4 & 2.5 & 7.2 & 22.4 & 29.2 & 14.9 & 3.6 \\
\hline
\end{tabular}


Table 9C. Physical and chemical analyses of pedon S84GA-231-004

[Units of measure for all values given in table 5. - , not detected; TR, trace]

\begin{tabular}{|c|c|c|c|c|c|c|c|c|c|c|c|c|c|}
\hline \multirow[b]{2}{*}{$\begin{array}{l}\text { Depth } \\
\text { (cm) }\end{array}$} & \multirow{2}{*}{\multicolumn{3}{|c|}{ Horizon }} & \multicolumn{5}{|c|}{ Dithionite-citrate } & \multicolumn{3}{|c|}{ Ratio clay } & \multirow{2}{*}{\multicolumn{2}{|c|}{$\begin{array}{c}\text { Bulk density } \\
\text { ( } 1 / 3 \text { bar })\end{array}$}} \\
\hline & & & & \multicolumn{3}{|c|}{$\begin{array}{c}\text { Extractable } \\
\mathrm{Fe}\end{array}$} & \multicolumn{2}{|c|}{$\begin{array}{c}\text { Extractable } \\
\qquad \mathrm{Al}\end{array}$} & $\mathrm{CEC}^{1}$ & \multicolumn{2}{|c|}{15 bar } & & \\
\hline $0-13$ & \multicolumn{3}{|c|}{$\mathrm{A}$} & \multicolumn{3}{|c|}{0.5} & \multicolumn{2}{|l|}{0.2} & 0.86 & \multicolumn{2}{|c|}{0.63} & \multicolumn{2}{|c|}{1.14} \\
\hline $13-38 \ldots \ldots$ & \multicolumn{3}{|c|}{$\mathrm{E}$} & \multicolumn{3}{|c|}{.4} & \multicolumn{2}{|l|}{.1} & .21 & \multicolumn{2}{|c|}{.39} & \multicolumn{2}{|c|}{1.64} \\
\hline $38-61 \ldots \ldots$ & \multicolumn{3}{|c|}{ BA } & & 1.3 & & \multicolumn{2}{|l|}{3} & .13 & \multicolumn{2}{|c|}{.35} & \multicolumn{2}{|c|}{1.47} \\
\hline $61-91 \ldots \ldots$ & \multicolumn{3}{|c|}{ Bt 1} & & 3.4 & & \multicolumn{2}{|l|}{.7} & .13 & \multicolumn{2}{|c|}{.36} & \multicolumn{2}{|c|}{1.37} \\
\hline $91-117 \ldots \ldots$ & \multicolumn{3}{|c|}{$\mathrm{Bt} 2$} & & 5.2 & & \multicolumn{2}{|l|}{.8} & .11 & \multicolumn{2}{|c|}{.42} & \multicolumn{2}{|c|}{1.43} \\
\hline $117-145 \ldots$ & \multicolumn{3}{|c|}{$\mathrm{Bt} 3$} & & 6.2 & & \multicolumn{2}{|l|}{.8} & .10 & & 46 & 1. & 38 \\
\hline $145-168 \ldots$. & & $\mathrm{B} / \mathrm{C}$ & & & 4.2 & & .4 & & .06 & & 40 & 1. & 52 \\
\hline $168-183 \ldots$ & & $\mathrm{Cr}$ & & & 1.2 & & .1 & & .04 & & 38 & 2. & 01 \\
\hline & & & $\begin{array}{l}\mathrm{NH} \\
\text { tracta }\end{array}$ & $\begin{array}{l}A C \\
\text { ba }\end{array}$ & & & & & $\mathrm{CEC}^{1}$ & & & pl & $\mathrm{H}$ \\
\hline $\begin{array}{c}\text { Depth } \\
(\mathrm{cm})\end{array}$ & Horizon & $\mathrm{Ca}$ & $\mathrm{Mg}$ & $\mathrm{Na}$ & $\mathrm{K}$ & Acidity & $\begin{array}{c}\text { Extractable } \\
\mathrm{Al}\end{array}$ & $\begin{array}{l}\text { Sum of } \\
\text { cations }\end{array}$ & $\mathrm{NH}_{4} \mathrm{OAC}$ & Bases + $\mathrm{Al}$ & $\begin{array}{c}\mathrm{Al} \\
\text { saturation }\end{array}$ & $\begin{array}{c}\mathrm{CaCl}_{2} \\
(1: 2)\end{array}$ & $\begin{array}{l}\mathrm{H}_{2} \mathrm{O} \\
(1: 1)\end{array}$ \\
\hline $0-13 \ldots \ldots$ & $\mathrm{A}$ & 0.8 & 0.2 & 0.1 & 0.1 & 7.8 & 1.2 & 9.0 & 6.9 & 2.4 & 50 & 4.5 & 5.0 \\
\hline $13-38 \ldots \ldots$ & $\mathrm{E}$ & .1 & TR & .1 & TR & 2.3 & .4 & 2.5 & 1.6 & .6 & 67 & 4.4 & 4.8 \\
\hline $38-61 \ldots \ldots$ & BA & .3 & .4 & TR & .1 & 3.9 & .7 & 4.7 & 2.9 & 1.5 & 47 & 4.4 & 4.9 \\
\hline $61-91 \ldots \ldots$ & $\mathrm{Bt} 1$ & .5 & 1.0 & .1 & .1 & 8.3 & 1.2 & 10.0 & 5.9 & 2.9 & 41 & 4.3 & 4.9 \\
\hline $91-117 \ldots$ & $\mathrm{Bt} 2$ & .2 & .7 & TR & .1 & 9.3 & .0 & 10.3 & 6.1 & 2.0 & 50 & 4.5 & 5.1 \\
\hline $117-145 \ldots$ & $\mathrm{Bt} 3$ & .1 & .3 & .1 & .1 & 9.4 & .8 & 10.0 & 5.5 & 1.4 & 57 & 4.5 & 5.1 \\
\hline $145-168 \ldots$ & $\mathrm{B} / \mathrm{C}$ & TR & .1 & .1 & - & 5.0 & .7 & 5.2 & 2.8 & .9 & 78 & 4.5 & 4.9 \\
\hline $168-183 \ldots$ & $\mathrm{Cr}$ & TR & TR & TR & - & 1.7 & .4 & 1.7 & .6 & .4 & 100 & 4.5 & 5.0 \\
\hline
\end{tabular}

${ }^{1}$ Cation exchange capacity.

Table 10A. Field description of pedon S84GA-231-002

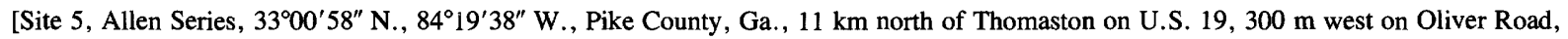
$15 \mathrm{~m}$ north of road in woods, Zebulon 7.5-min quadrangle. Parent material is Hollis Quartzite at the toe of a large gravity-slide block; surface elevation is $256 \mathrm{~m}$ above mean sea level on a 10-percent east-facing slope on the slide block. Vegetation dominantly pine forest. Site is well drained under a udic moisture regime. No entry, no data]

\begin{tabular}{|c|c|c|c|c|c|c|c|}
\hline $\begin{array}{l}\text { Depth } \\
\text { (cm) }\end{array}$ & Horizon $^{1}$ & Moist color ${ }^{2}$ & Texture $^{3}$ & Structure $^{4}$ & Consistence $^{5}$ & Roots $^{6}$ & Boundary ${ }^{7}$ \\
\hline $0-13 \ldots \ldots \ldots \ldots$ & A & $10 \mathrm{YR} 5 / 3$ & sl & If $\mathrm{gr}$ & vf & $\mathrm{m} 12$ & cs \\
\hline $13-22 \ldots \ldots \ldots \ldots$ & $A B$ & $7.5 Y R 5 / 6$ & sl & if $\mathrm{gr}$ & vf & $\mathrm{m} 12$ & cs \\
\hline $22-44 \ldots \ldots \ldots \ldots$ & BA & 5 YR 5/6 & scl & $1 \mathrm{~m}$ sbk & f & $\mathrm{c} 12$ & cs \\
\hline 44-74. & Btl & 2.5 YR 4/6 & $\mathrm{cl}$ & $2 \mathrm{~m} \mathrm{sbk}$ & f & f1 & gs \\
\hline $74-97 \ldots \ldots$ & $\mathrm{Bt} 2$ & $2.5 Y R \quad 4 / 6$ & $\mathrm{cl}$ & $2 \mathrm{~m} \mathrm{sbk}$ & fi & f1 & cs \\
\hline $97-144 \ldots \ldots \ldots \ldots$ & $\mathrm{Bt} 3$ & $2.5 Y R \quad 4 / 6$ & $\mathrm{cl}$ & $2 \mathrm{~m}$ abk/0 sbk & fi & & $\mathrm{cw}$ \\
\hline $144-170 \ldots \ldots \ldots$ & $\mathrm{Bt} 4$ & $2.5 Y R \quad 4 / 6$ & $\mathrm{cl}$ & $2 \mathrm{~m} \mathrm{sbk}$ & fi & & $\mathrm{cw}$ \\
\hline $170-205 \ldots \ldots \ldots$ & $\mathrm{B} / \mathrm{C}$ & $2.5 Y R \quad 4 / 6$ & $\mathrm{cl}$ & $2 \mathrm{~m}$ sbk and $\mathrm{M}$ & $\mathrm{fi}$ & & gw \\
\hline $205-225 \ldots \ldots \ldots$ & C & $2.5 Y R 4 / 6$ & $\mathrm{scl}$ & $\mathbf{M}$ & $f$ & & \\
\hline $300-360 \ldots$ & $2 \mathrm{C}$ & 01 & & & & & \\
\hline
\end{tabular}

${ }^{1} \mathrm{~A}$, few fine gravel; AB, few fine gravel; BA, few fine gravel; Bt1, few fine gravel; Bt2, platy structure in upper $7 \mathrm{~cm}$, roots slightly restricted, few fine gravel; Bt3, few small quartzite fragments; Bt4, common small quartzite fragments; B/C, common fine and medium quartzite fragments (B portion is red, and $\mathrm{C}$ portion is yellow); $\mathrm{C}$, mottled yellows, browns, and reds, common fine and medium quartzite fragments.

${ }^{2}$ Munsell notation.

${ }^{3}$ sl, sandy loam; cl, clay loam; scl, sandy clay loam.

${ }^{4} 0$, very weak; 1 , weak; 2 , moderate; f, fine; m, medium; gr, granular; abk, angular blocky; sbk, subangular blocky; M, massive; /, breaking to.

${ }^{5}$, friable; vf, very friable; fi, firm.

${ }^{6} \mathrm{~m}$, many; c, common; $\mathrm{f}$, few; 1 , fine; 2 , medium.

${ }^{7} \mathrm{cs}$, clear smooth; cw, clear wavy; gw, gradual wavy; gs, gradual smooth. 
Table 10B. Textural analyses of horizons for pedon S84GA-231-002

[Sampled as fine, loamy, mixed, thermic Typic Hapludult. Grain sizes in millimeters; all other values in weight percent. VF, very fine; F, fine; M, medium; $\mathrm{C}$, coarse; $\mathrm{VC}$, very coarse. - , not detected]

\begin{tabular}{|c|c|c|c|c|c|c|c|c|c|c|c|c|}
\hline \multirow[b]{2}{*}{$\begin{array}{l}\text { Depth } \\
(\mathrm{cm})\end{array}$} & \multirow[b]{2}{*}{ Horizon } & \multicolumn{3}{|c|}{ Total } & \multirow{2}{*}{$\frac{\text { Clay }}{\mathrm{F}}$} & \multicolumn{2}{|c|}{ Silt } & \multicolumn{5}{|c|}{ Sand } \\
\hline & & $\begin{array}{c}\text { Clay } \\
(<.002)\end{array}$ & $\begin{array}{c}\text { Silt } \\
(.002-.05)\end{array}$ & $\begin{array}{l}\text { Sand } \\
(.05-2)\end{array}$ & & $\begin{array}{c}F \\
(.002-.02)\end{array}$ & $\begin{array}{c}\mathrm{C} \\
(.02-.05)\end{array}$ & $\begin{array}{c}\text { VF } \\
(.05-.10)\end{array}$ & $\begin{array}{c}F \\
(.10-.25)\end{array}$ & $\begin{array}{c}M \\
(.25-.50)\end{array}$ & $\begin{array}{c}\mathrm{C} \\
(.5-1)\end{array}$ & $\begin{array}{c}\text { VC } \\
(1-2)\end{array}$ \\
\hline 0-13. & A & 8.7 & 29.5 & 61.8 & 2.8 & 15.0 & 4.5 & 20.2 & 23.7 & 9.4 & 4.1 & 4.4 \\
\hline $13-22$. & $\mathrm{AB}$ & 8.8 & 29.1 & 62.1 & 2.9 & 14.8 & 14.3 & 21.4 & 23.8 & 9.0 & 3.8 & 4.1 \\
\hline $22-44 \ldots$. & . BA & 14.9 & 28.4 & 56.7 & 6.0 & 14.5 & 13.9 & 19.7 & 22.3 & 8.5 & 3.5 & 2.7 \\
\hline $44-74 \ldots$. & . Bt1 & 44.7 & 18.6 & 36.7 & 20.0 & 7.8 & 10.8 & 13.0 & 13.9 & 5.1 & 2.4 & 2.3 \\
\hline $74-97 \ldots$ & . $\mathrm{Bt} 2$ & 58.9 & 16.1 & 25.0 & 22.2 & 7.4 & 8.7 & 9.9 & 8.3 & 3.2 & 2.0 & 1.6 \\
\hline $97-144 \ldots$ & . $\mathrm{Bt} 3$ & 44.0 & 18.8 & 37.2 & 17.1 & 6.9 & 11.9 & 15.4 & 9.5 & 4.2 & 4.2 & 3.9 \\
\hline $144-170 \ldots$ & . $\mathrm{Bt} 4$ & 23.4 & 24.4 & 52.2 & 8.7 & 8.6 & 15.8 & 21.5 & 12.2 & 4.9 & 6.1 & 7.5 \\
\hline $170-205 \ldots$ & . $\mathrm{B} / \mathrm{C}$ & 16.7 & 29.4 & 53.9 & 5.8 & 10.6 & 18.8 & 22.5 & 12.6 & 5.9 & 6.7 & 6.2 \\
\hline $205-225 \ldots$ & . C & 12.4 & 30.8 & 56.8 & - & 11.3 & 19.5 & 23.1 & 13.2 & 6.2 & 7.1 & 7.2 \\
\hline $300-360 \ldots$ & . $2 \mathrm{C}$ & 7.7 & 14.6 & 77.7 & - & 9.2 & 5.4 & 13.7 & 27.7 & 21.2 & 11.1 & 4.0 \\
\hline
\end{tabular}

Table 10C. Physical and chemical analyses of pedon S84GA-231-002

[Units of measure for all values given in table 5. - , not detected; TR, trace]

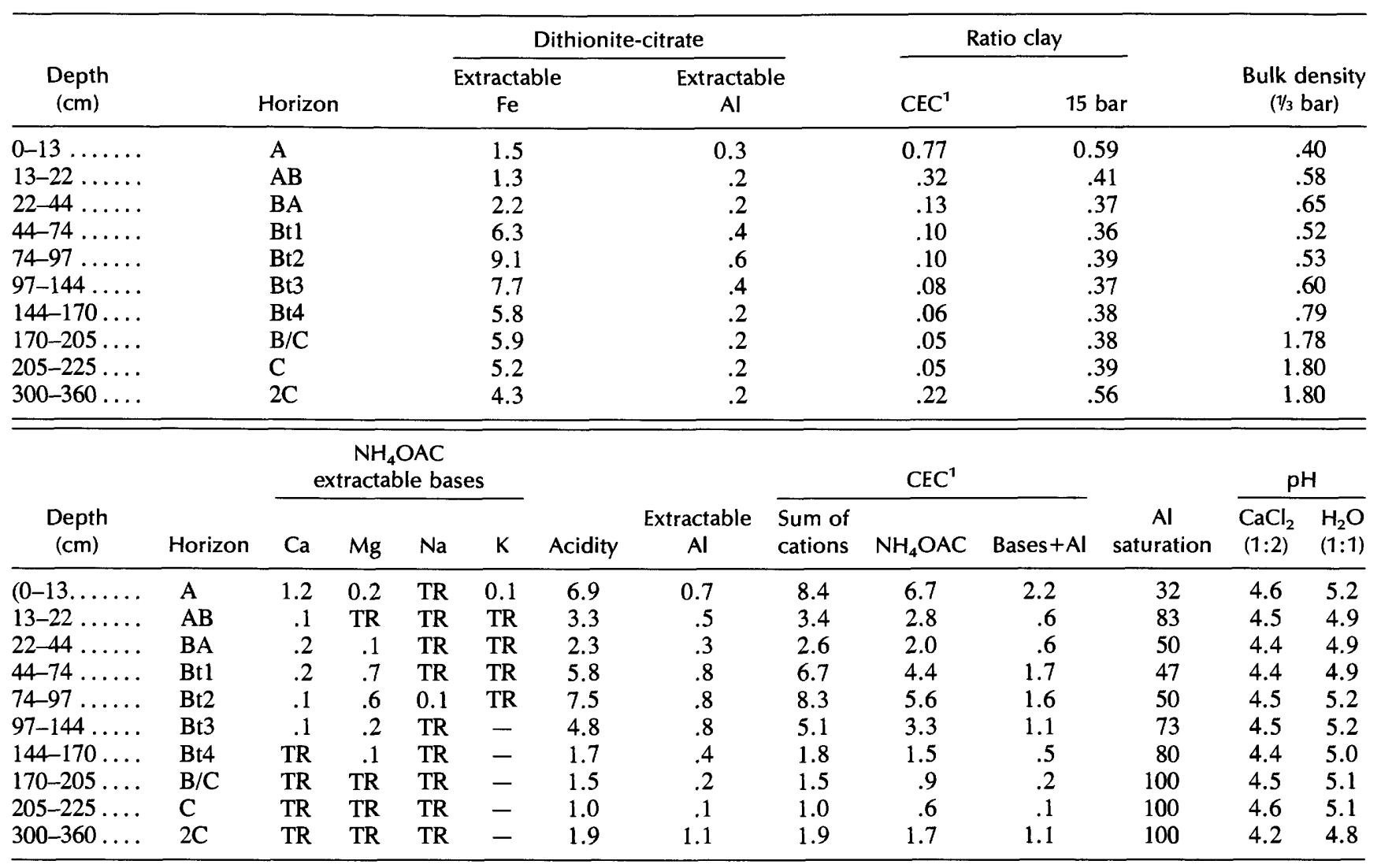

${ }^{1}$ Cation exchange capacity. 
Table 11A. Field description of pedon S84GA-293-001

[Site 6, series not designated, $32^{\circ} 57^{\prime} 19^{\prime \prime}$ N., $84^{\circ} 25^{\prime} 00^{\prime \prime}$ W., Upson County, Ga., $8 \mathrm{~km}$ northwest of Thomaston, Sunset Village 7.5-min quadrangle. Parent material is alluvial fan sediments derived mainly from Hollis Quartzite; surface elevation $287 \mathrm{~m}$ above mean sea level on a 3-percent east-facing slope. Vegetation dominantly pine forest and some hardwood. Site is well drained under a udic moisture regime. No entry, no data]

\begin{tabular}{|c|c|c|c|c|c|c|c|}
\hline $\begin{array}{l}\text { Depth } \\
\text { (cm) }\end{array}$ & Horizon $^{1}$ & Moist color ${ }^{2}$ & Texture $^{3}$ & Structure $^{4}$ & Consistence $^{5}$ & Roots $^{6}$ & Boundary ${ }^{7}$ \\
\hline $0-18$ & Ap & $10 \mathrm{YR} 4 / 3$ & sl & If $\mathrm{gr}$ & vf & $\mathrm{m} 1$ & cs \\
\hline $18-45 \ldots \ldots \ldots \ldots$ & $\mathrm{AB}$ & 10YR $5 / 6$ & sl & If sbk & $\mathrm{f}$ & $\mathrm{m} 1$ & cs \\
\hline $45-69 \ldots \ldots \ldots \ldots$ & BA & 7.5 YR 5/6 & sl & $1 \mathrm{~m}$ sbk & f & c1 & gs \\
\hline 69-97. & Bt1 & $7.5 Y R$ 5/8 & $\mathrm{scl}$ & $2 \mathrm{~m}$ sbk & f & f1 & gs \\
\hline $97-146 \ldots \ldots \ldots \ldots$ & $\mathrm{Bt} 2$ & 7.5 YR $5 / 8$ & $\mathrm{scl}$ & $2 \mathrm{~m} \mathrm{sbk}$ & f & f1 & cs \\
\hline $146-175 \ldots \ldots \ldots$ & $\mathrm{Bx} 1$ & $\begin{array}{l}2.5 \text { YR } 4 / 8 \\
7.5 \text { YR } 5 / 8\end{array}$ & $\mathrm{scl}$ & $\mathbf{M}$ & & & $\operatorname{cs}$ \\
\hline $175-205 \ldots \ldots \ldots$ & $B \times 2$ & $\begin{array}{l}2.5 \text { YR } 4 / 8 \\
7.5 \text { YR } 5 / 8\end{array}$ & g scl & $\mathbf{M}$ & & & \\
\hline
\end{tabular}

${ }^{1} \mathrm{Bx} 1$, moist colors are mottled; red portion ( 35 percent by volume) is horizontally oriented and firm and brittle, brown portion is friable, few fine and coarse gravel and common medium gravel, few nodules of plinthite; Bx2, moist colors are mottled, red portion ( 35 percent by volume) is very hard in places, brown portion is friable, few fine, medium, and coarse gravel.

${ }^{2}$ Munsell notation.

${ }^{3} \mathrm{sl}$, sandy loam; scl, sandy clay loam; g, gravelly.

${ }^{4}$, weak; 2 , moderate; f, fine; $\mathrm{m}$, medium; gr, granular; sbk, subangular blocky; $M$, massive.

${ }^{5}$, friable; vf, very friable.

${ }^{6} \mathrm{~m}$, many; c, common; f, few; 1 , fine.

${ }^{7} \mathrm{cs}$, clear smooth; gs, gradual smooth.

Table 11B. Textural analyses of horizons for pedon S84GA-293-001

[Sampled as fine, loamy, mixed, thermic Typic Hapludult. Grain sizes in millimeters; all other values in weight percent. VF, very fine; F, fine; M, medium; C, coarse; VC, very coarse]

\begin{tabular}{|c|c|c|c|c|c|c|c|c|c|c|c|c|}
\hline \multirow[b]{2}{*}{$\begin{array}{c}\text { Depth } \\
\text { (cm) }\end{array}$} & \multirow[b]{2}{*}{ Horizon } & \multicolumn{3}{|c|}{ Total } & \multirow{2}{*}{$\frac{\text { Clay }}{F}$} & \multicolumn{2}{|c|}{ Silt } & \multicolumn{5}{|c|}{ Sand } \\
\hline & & $\begin{array}{c}\text { Clay } \\
(<.002)\end{array}$ & $\begin{array}{c}\text { Silt } \\
(.002-.05)\end{array}$ & $\begin{array}{l}\text { Sand } \\
(.05-2)\end{array}$ & & $\begin{array}{c}F \\
(.002-.02)\end{array}$ & $\begin{array}{c}\mathrm{C} \\
(.02-.05)\end{array}$ & $\begin{array}{c}\text { VF } \\
(.05-.10)\end{array}$ & $\begin{array}{c}F \\
(.10-.25)\end{array}$ & $\underset{(.25-.50)}{M}$ & $\begin{array}{c}\mathrm{C} \\
(.5-1)\end{array}$ & $\begin{array}{c}\text { VC } \\
(1-2)\end{array}$ \\
\hline $0-18$ & Ap & 9.0 & 14.6 & 76.4 & 4.4 & 10.0 & 4.6 & 8.6 & 26.2 & 26.3 & 13.3 & 2.0 \\
\hline $18-45$ & $\mathrm{AB}$ & 5.0 & 11.2 & 83.8 & 2.0 & 6.9 & 4.3 & 8.3 & 28.2 & 29.5 & 15.4 & 2.4 \\
\hline $45-69$. & BA & 10.5 & 6.7 & 75.3 & 5.3 & 9.5 & 4.7 & 9.3 & 29.0 & 23.4 & 11.6 & 2.0 \\
\hline 69-97. & . Btl & 23.0 & 10.7 & 66.3 & 13.8 & 7.0 & 3.7 & 7.3 & 22.1 & 21.8 & 12.4 & 2.7 \\
\hline $97-146 \ldots$ & . $\mathrm{Bt} 2$ & 30.3 & 8.8 & 60.9 & 18.1 & 5.4 & 3.4 & 6.5 & 19.2 & 19.8 & 11.5 & 3.9 \\
\hline $146-175 \ldots$ & . $\mathrm{Bx} 1$ & 26.5 & 9.2 & 64.3 & 15.1 & 5.2 & 4.0 & 6.1 & 17.0 & 18.3 & 14.6 & 8.3 \\
\hline $175-205 \ldots$ & - $\mathrm{Bx} 2$ & 28.3 & 14.2 & 65.0 & 15.9 & 3.4 & 3.3 & 5.2 & 16.1 & 21.1 & 16.3 & 6.3 \\
\hline
\end{tabular}


Table 11C. Physical and chemical analyses of pedon S84GA-293-001

[Units of measure for all values given in table 5. TR, trace]

\begin{tabular}{|c|c|c|c|c|c|c|c|c|c|c|c|c|c|}
\hline \multirow[b]{2}{*}{$\begin{array}{l}\text { Depth } \\
(\mathrm{cm})\end{array}$} & \multirow{2}{*}{\multicolumn{3}{|c|}{ Horizon }} & \multicolumn{5}{|c|}{ Dithionite-citrate } & \multicolumn{3}{|c|}{ Ratio clay } & \multirow{2}{*}{\multicolumn{2}{|c|}{$\begin{array}{c}\text { Bulk density } \\
\text { ( } 1 / 3 \text { bar })\end{array}$}} \\
\hline & & & & \multicolumn{3}{|c|}{$\begin{array}{c}\text { Extractable } \\
\text { Fe }\end{array}$} & \multicolumn{2}{|c|}{$\begin{array}{c}\text { Extractable } \\
\mathrm{Al}\end{array}$} & $\mathrm{CEC}^{1}$ & \multicolumn{2}{|c|}{15 bar } & & \\
\hline $0-18$ & \multicolumn{3}{|c|}{$A p$} & \multicolumn{3}{|c|}{0.4} & \multicolumn{2}{|l|}{0.2} & 0.18 & \multicolumn{2}{|c|}{0.32} & \multicolumn{2}{|c|}{1.38} \\
\hline $18-45 \ldots \ldots$ & \multicolumn{3}{|c|}{$\mathrm{AB}$} & \multicolumn{3}{|c|}{.2} & \multicolumn{2}{|l|}{.1} & .40 & \multicolumn{2}{|c|}{.44} & \multicolumn{2}{|c|}{1.50} \\
\hline $45-69 \ldots \ldots$ & & BA & & \multicolumn{3}{|c|}{.5} & \multicolumn{2}{|l|}{.1} & .19 & \multicolumn{2}{|c|}{.34} & \multicolumn{2}{|c|}{1.60} \\
\hline $69-97 \ldots \ldots$ & & Bt1 & & \multicolumn{3}{|c|}{1.4} & \multicolumn{2}{|l|}{.3} & .17 & \multicolumn{2}{|c|}{.32} & \multicolumn{2}{|c|}{1.64} \\
\hline $97-146 \ldots \ldots$ & & Bt2 & & \multicolumn{3}{|c|}{2.4} & \multicolumn{2}{|l|}{.5} & .14 & \multicolumn{2}{|c|}{.35} & \multicolumn{2}{|c|}{1.71} \\
\hline $146-175 \ldots$ & & Bx1 & & \multicolumn{3}{|c|}{3.9} & \multicolumn{2}{|l|}{.7} & .17 & \multicolumn{2}{|c|}{.43} & 1.7 & \\
\hline $175-205 \ldots$ & & $\mathrm{Bx} 2$ & & & 2.4 & & .4 & & .17 & & 99 & 2.1 & \\
\hline & & & $\begin{array}{r}\mathrm{NH} \\
\text { tracta }\end{array}$ & $\begin{array}{l}\text { DAC } \\
\text { le ba }\end{array}$ & & & & & $\mathrm{CEC}^{1}$ & & & $\mathrm{ph}$ & \\
\hline $\begin{array}{l}\text { Depth } \\
(\mathrm{cm})\end{array}$ & Horizon & $\mathrm{Ca}$ & $\mathrm{Mg}$ & $\mathrm{Na}$ & K & Acidity & $\begin{array}{c}\text { Extractable } \\
\qquad \mathrm{Al}\end{array}$ & $\begin{array}{l}\text { Sum of } \\
\text { cations }\end{array}$ & $\mathrm{NH}_{4} \mathrm{OAC}$ & Bases $+\mathrm{Al}$ & $\underset{\text { saturation }}{\mathrm{Al}}$ & $\begin{array}{l}\mathrm{CaCl}_{2} \\
(1: 2)\end{array}$ & $\begin{array}{l}\mathrm{H}_{2} \mathrm{O} \\
(1: 1)\end{array}$ \\
\hline $0-18 \ldots \ldots$ & $\mathrm{Ap}$ & 0.5 & 0.2 & TR & 0.1 & 1.3 & 0.2 & 2.1 & 1.6 & 1.0 & 20 & 4.9 & 5.5 \\
\hline $18-45 \ldots \ldots$ & $\mathrm{AB}$ & .7 & .1 & TR & .1 & 2.3 & .2 & 3.2 & 2.0 & 1.1 & 18 & 4.9 & 5.5 \\
\hline $45-69 \ldots \ldots$ & BA & .7 & .2 & TR & .1 & 1.7 & .1 & 2.7 & 2.0 & 1.1 & 9 & 4.7 & 5.2 \\
\hline $69-97 \ldots \ldots$ & $\mathrm{Bt} 1$ & 1.6 & .6 & TR & .1 & 3.6 & .1 & 5.9 & 4.0 & 2.4 & 4 & 4.9 & 5.4 \\
\hline $97-146 \ldots \ldots$ & $\mathrm{Bt} 2$ & .6 & .5 & TR & .1 & 5.4 & .7 & 6.6 & 4.3 & 1.9 & 37 & 4.5 & 5.1 \\
\hline $146-175 \ldots$ & $\mathrm{Bx} 1$ & .1 & .2 & TR & .1 & 5.4 & .1 & 5.8 & 4.6 & 1.5 & 73 & 4.4 & 5.2 \\
\hline $175-205 \ldots$ & $\mathrm{Bx} 2$ & .2 & .2 & TR & .1 & 5.4 & .8 & 5.9 & 4.8 & 2.3 & 78 & 4.3 & 5.2 \\
\hline
\end{tabular}

${ }^{1}$ Cation exchange capacity.

Table 12A. Field description of pedon S84GA-199-002

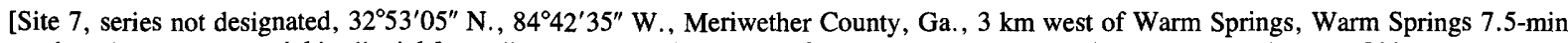
quadrangle. Parent material is alluvial fan sediment derived from Hollis Quartzite and Manchester Schist; surface elevation $288 \mathrm{~m}$ above mean sea level on a 3-percent north-facing slope. Vegetation dominantly pine forest and some hardwood. Site is well drained under a udic moisture regime. No entry, no data]

\begin{tabular}{|c|c|c|c|c|c|c|c|}
\hline $\begin{array}{l}\text { Depth } \\
(\mathrm{cm})\end{array}$ & Horizon $^{1}$ & Moist color ${ }^{2}$ & Texture $^{3}$ & Structure $^{4}$ & Consistence $^{5}$ & Roots $^{6}$ & Boundary ${ }^{7}$ \\
\hline $0-15 \ldots \ldots \ldots \ldots$ & Ap & $10 \mathrm{YR} 5 / 3$ & sl & If $\mathrm{gr}$ & & $\mathrm{ml}$ & as \\
\hline $15-44 \ldots \ldots \ldots \ldots$ & Bt1 & $2.5 \mathrm{YR} 4 / 8$ & $\mathrm{cl}$ & $2 \mathrm{~m}$ sbk & & $\mathrm{c} 1$ & gs \\
\hline $44-98 \ldots \ldots$ & Bt2 & 2.5 YR 4/8 & $\mathrm{cl}$ & $2 \mathrm{~m} \mathrm{sbk}$ & $\mathrm{f}$ & fl & aw \\
\hline $98-130 \ldots$ & $2 \mathrm{Bx} 1$ & $2.5 Y R \quad 4 / 8$ & scl & $\mathbf{M}$ & vfib & f1 & gs \\
\hline $130-164 \ldots \ldots \ldots$ & $2 \mathrm{~B} \times 2$ & $2.5 \mathrm{YR} 4 / 8$ & scl & $\mathbf{M}$ & & & cs \\
\hline $164-195 \ldots \ldots \ldots$ & $2 \mathrm{~B} \times 3$ & $\begin{array}{l}7.5 \text { YR } 5 / 6 \\
2.5 Y R \quad 4 / 8\end{array}$ & sl & $\mathbf{M}$ & & & gs \\
\hline $195-235 \ldots \ldots \ldots$ & $2 \mathrm{Bx} 4$ & $\begin{array}{l}7.5 \text { YR } 5 / 6 \\
2.5 \text { YR } 4 / 8\end{array}$ & sl & $\mathbf{M}$ & & & gs \\
\hline $235-250 \ldots \ldots \ldots$ & $2 B \times 5$ & $\begin{array}{l}7.5 \text { YR } 5 / 8 \\
2.5 \text { YR } 4 / 8\end{array}$ & sl & $\mathbf{M}$ & & & \\
\hline
\end{tabular}

${ }^{1} \mathrm{Ap}$,few fine gravel; Bt2, split for sampling at $66 \mathrm{~cm}$ (66-98 $\mathrm{cm}$ is sample $\left.84 \mathrm{P} 2479\right)$, few fine gravel; $2 \mathrm{Bx} 1$, strong brown portion is firm sandy clay having few fine roots and few fine gravel, red portion ( 70 percent by volume) is very firm and brittle; $2 \mathrm{Bx} 2$, red portion ( 60 percent by volume) is very firm and brittle, strong brown portion is firm sandy clay having few fine gravel; $2 \mathrm{Bx} 3$, red portion (50 percent by volume) is firm and brittle, strong brown portion is firm, common fine and medium gravel; $2 \mathrm{Bx} 4$, brown portion ( 60 percent by volume) is friable, red portion is firm and brittle, few fine gravel; $2 \mathrm{Bx} 5$, third moist color is $10 \mathrm{YR} 6 / 4$, brown portion ( 70 percent by volume) is friable, red portion is firm and brittle, moist colors are mottled.

${ }^{2}$ Munsell notation.

${ }^{3} \mathrm{sl}$, sandy loam; cl, clay loam; scl, sandy clay loam.

${ }^{4} 1$, weak; 2 , moderate; $\mathrm{f}$, fine; $\mathrm{m}$, medium; gr, granular; sbk, subangular blocky; $\mathrm{M}$, massive.

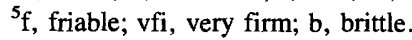

${ }^{6} \mathrm{~m}$, many; c, common; f, few; 1 , fine.

${ }^{7}$ as, abrupt smooth; aw, abrupt wavy; cs, clear smooth; gs, gradual smooth. 
Table 12B. Textural analyses of horizons for pedon S84GA-199-002

[Grain sizes in millimeters; all other values in weight percent. VF, very fine; F, fine; M, medium; C, coarse; VC, very coarse]

\begin{tabular}{|c|c|c|c|c|c|c|c|c|c|c|c|c|}
\hline \multirow[b]{2}{*}{$\begin{array}{c}\text { Depth } \\
(\mathrm{cm})\end{array}$} & \multirow[b]{2}{*}{ Horizon } & \multicolumn{3}{|c|}{ Total } & \multirow{2}{*}{$\frac{\text { Clay }}{\mathrm{F}}$} & \multicolumn{2}{|c|}{ Silt } & \multicolumn{5}{|c|}{ Sand } \\
\hline & & $\begin{array}{c}\text { Clay } \\
(<.002)\end{array}$ & $\begin{array}{c}\text { Silt } \\
(.002-.05)\end{array}$ & $\begin{array}{l}\text { Sand } \\
(.05-2)\end{array}$ & & $\begin{array}{c}F \\
(.002-.02)\end{array}$ & $\begin{array}{c}C \\
(.02-.05)\end{array}$ & $\begin{array}{c}V F \\
(.05-.10)\end{array}$ & $\begin{array}{c}\mathrm{F} \\
(.10-.25)\end{array}$ & $\begin{array}{c}M \\
(.25-.50)\end{array}$ & $\begin{array}{c}C \\
(.5-1)\end{array}$ & $\begin{array}{c}\text { VC } \\
(1-2)\end{array}$ \\
\hline $0-15$ & A & 8.8 & 15.8 & 75.4 & 4.4 & 10.0 & 5.8 & 11.5 & 29.1 & 20.4 & 9.8 & 4.6 \\
\hline $15-44 \ldots$ & Bt1 & 51.7 & 9.6 & 38.7 & 27.5 & 6.7 & 2.9 & 5.7 & 13.8 & 10.4 & 5.7 & 3.1 \\
\hline $44-66$ & $\mathrm{Bt} 2$ & 44.7 & 12.0 & 43.3 & 24.7 & 8.8 & 3.2 & 6.5 & 15.4 & 11.7 & 6.4 & 3.3 \\
\hline 66-98 & $\mathrm{Bt} 2$ & 48.0 & 8.5 & 43.5 & 26.2 & 6.2 & 2.3 & 5.9 & 14.9 & 11.8 & 7.1 & 3.8 \\
\hline $98-130$. & $2 \mathrm{~B} \times 1$ & 40.2 & 7.1 & 52.7 & 21.4 & 4.8 & 2.3 & 5.9 & 15.8 & 14.0 & 10.0 & 7.0 \\
\hline $130-164 \ldots$ & $2 \mathrm{Bx} 2$ & 30.0 & 7.1 & 62.9 & 14.7 & 3.9 & 3.2 & 5.9 & 17.1 & 17.6 & 12.4 & 9.9 \\
\hline $164-195 \ldots$ & $2 \mathrm{~B} \times 3$ & 28.2 & 5.7 & 65.6 & 12.6 & 2.8 & 2.9 & 6.5 & 19.8 & 18.3 & 12.2 & 8.8 \\
\hline $195-235 \ldots$ & $2 \mathrm{Bx} 4$ & 30.2 & 6.8 & 63.0 & 11.7 & 4.2 & 2.6 & 4.3 & 15.4 & 20.6 & 14.4 & 8.3 \\
\hline $235-250 .$. & $2 \mathrm{~B} \times 5$ & 32.6 & 6.4 & 61.0 & 12.4 & 3.9 & 2.5 & 5.3 & 16.2 & 20.2 & 12.9 & 6.4 \\
\hline
\end{tabular}

Table 12C. Physical and chemical analyses of pedon S84GA-199-002

[Units of measure for all values given in table 5. - , not detected; TR, trace]

\begin{tabular}{|c|c|c|c|c|c|c|c|c|}
\hline \multirow[b]{2}{*}{$\begin{array}{l}\text { Depth } \\
(\mathrm{cm})\end{array}$} & \multirow[b]{2}{*}{ Horizon } & \multicolumn{2}{|c|}{ Dithionite-citrate } & \multicolumn{2}{|c|}{ Ratio clay } & \multirow[b]{2}{*}{$\begin{array}{l}\text { Bulk density } \\
\text { (1/3 bar) }\end{array}$} & \multicolumn{2}{|c|}{ Water content } \\
\hline & & $\begin{array}{c}\text { Extractable } \\
\text { Fe }\end{array}$ & $\begin{array}{c}\text { Extractable } \\
\text { Al }\end{array}$ & $\mathrm{CEC}^{1}$ & 15 bar & & $1 / 3 \mathrm{bar}^{2}$ & $15 \mathrm{bar}^{3}$ \\
\hline $0-15$ & A & 0.7 & 0.2 & 0.30 & 0.43 & 1.54 & 12.5 & 3.5 \\
\hline $15-44 \ldots \ldots$ & Bt1 & 4.0 & .7 & .11 & .32 & 1.43 & 19.0 & 16.7 \\
\hline $44-66 \ldots \ldots$ & $\mathrm{Bt} 2$ & 3.7 & .6 & .11 & .34 & 1.30 & 26.0 & 15.0 \\
\hline $66-98 \ldots \ldots$ & $\mathrm{Bt} 2$ & 4.0 & .6 & .09 & .33 & 1.39 & 24.8 & 15.9 \\
\hline $98-130 \ldots \ldots$ & $2 \mathrm{~B} \times 1$ & 4.3 & .6 & .08 & .36 & 1.68 & 17.9 & 14.6 \\
\hline $130-164 \ldots$. & $2 \mathrm{~B} \times 2$ & 3.6 & .5 & .09 & .40 & 1.71 & 17.2 & 12.1 \\
\hline $164-195 \ldots$ & $2 \mathrm{~B} \times 23$ & 2.7 & .4 & .08 & .39 & .80 & 15.5 & 11.2 \\
\hline $195-235 \ldots$ & $2 \mathrm{Bx} 4$ & 2.0 & .3 & .10 & .41 & 1.75 & 15.9 & 12.3 \\
\hline $235-250 \ldots$ & $2 \mathrm{~B} \times 5$ & 1.6 & .3 & .10 & .37 & 1.73 & 16.0 & 12.1 \\
\hline
\end{tabular}

\begin{tabular}{|c|c|c|c|c|c|c|c|c|c|c|c|c|c|}
\hline \multirow[b]{2}{*}{$\begin{array}{l}\text { Depth } \\
(\mathrm{cm})\end{array}$} & \multirow[b]{2}{*}{ Horizon } & \multicolumn{4}{|c|}{$\begin{array}{c}\mathrm{NH}_{4} \mathrm{OAC} \\
\text { extractable bases }\end{array}$} & \multirow[b]{2}{*}{ Acidity } & \multirow[b]{2}{*}{$\begin{array}{c}\text { Extractable } \\
\mathrm{Al}\end{array}$} & \multicolumn{3}{|c|}{$\mathrm{CEC}^{1}$} & \multirow[b]{2}{*}{$\begin{array}{c}\mathrm{Al} \\
\text { saturation }\end{array}$} & \multicolumn{2}{|c|}{$\mathrm{pH}$} \\
\hline & & $\mathrm{Ca}$ & $\mathrm{Mg}$ & $\mathrm{Na}$ & $\mathrm{K}$ & & & $\begin{array}{l}\text { Sum of } \\
\text { cations }\end{array}$ & $\mathrm{NH}_{4} \mathrm{OAC}$ & Bases $+\mathrm{Al}$ & & $\begin{array}{l}\mathrm{CaCl}_{2} \\
(1: 2)\end{array}$ & $\begin{array}{l}\mathrm{H}_{2} \mathrm{O} \\
(1: 1)\end{array}$ \\
\hline $0-15$ & A & 0.8 & 0.2 & TR & 0.1 & 3.2 & 0.3 & 4.3 & 2.6 & 1.4 & 21 & 4.6 & 5.3 \\
\hline $15-44 \ldots \ldots$ & Bt1 & 2.0 & .5 & TR & TR & 6.5 & .2 & .0 & 5.5 & 2.7 & 7 & 4.9 & 5.4 \\
\hline $44-66 \ldots \ldots$ & Bt2 & 1.7 & .4 & TR & TR & 5.8 & .2 & .9 & 4.7 & 2.3 & 9 & 4.9 & 5.4 \\
\hline $66-98 \ldots \ldots$ & Bt2 & 1.3 & .3 & TR & - & 6.6 & .4 & .2 & 4.1 & 2.0 & 20 & 4.7 & 5.2 \\
\hline $98-130 \ldots \ldots$ & $2 \mathrm{Bx} 1$ & .4 & .1 & TR & - & 5.8 & .7 & 6.3 & 3.3 & 1.2 & 58 & 4.5 & 5.2 \\
\hline $130-164 \ldots$ & $2 \mathrm{~B} \times 2$ & .1 & .1 & $\mathrm{TR}$ & - & 4.5 & .6 & 4.7 & 2.6 & .8 & 75 & 4.5 & 4.9 \\
\hline $164-195 \ldots$ & $2 \mathrm{~B} \times 3$ & .1 & TR & TR & TR & 4.1 & .6 & 4.2 & 2.3 & .7 & 86 & 4.4 & 5.0 \\
\hline $195-235 \ldots$ & $2 \mathrm{Bx} 4$ & $\mathrm{TR}$ & TR & TR & - & 3.4 & .0 & 3.4 & 3.1 & 1.0 & 100 & 4.4 & 4.9 \\
\hline $235-250 \ldots$ & $2 \mathrm{Bx} 5$ & .1 & TR & TR & - & 4.1 & .2 & 4.2 & 3.1 & 1.3 & 92 & 4.3 & 4.9 \\
\hline
\end{tabular}

${ }^{1}$ Cation exchange capacity.

${ }^{2}$ Water content at $1 / 3$-bar pressure.

${ }^{3}$ Water content at 15 -bar pressure. 
Table 12D. Bulk chemistry of pedon S84GA-199-002

[All values in weight percent except for $\left(\mathrm{Fe}_{2} \mathrm{O}_{3}+\mathrm{Al}_{2} \mathrm{O}_{3}\right) / \mathrm{SiO}_{2}$, which is a ratio, and $\mathrm{H}_{2} \mathrm{O}$, which is in percent]

\begin{tabular}{|c|c|c|c|c|c|c|c|c|}
\hline & \multicolumn{8}{|c|}{ Horizon $^{2}$} \\
\hline$\underset{(0-15)}{A}$ & $\begin{array}{c}\text { Bt1 } \\
(15-44)\end{array}$ & $\begin{array}{c}\text { Bt2 } \\
(44-66)\end{array}$ & $\begin{array}{c}\text { Bt2 } \\
(66-98)\end{array}$ & $\begin{array}{c}2 \mathrm{~B} \times 1 \\
(98-130)\end{array}$ & $\begin{array}{c}2 B \times 2 \\
(130-164)\end{array}$ & $\begin{array}{c}2 \mathrm{Bx} 3 \\
(164-195)\end{array}$ & $\begin{array}{c}2 \mathrm{Bx} 4 \\
(195-235)\end{array}$ & $\begin{array}{c}2 \mathrm{~B} \times 5 \\
(235-250)\end{array}$ \\
\hline $\mathrm{SiO}_{2} \ldots \ldots \ldots \ldots \ldots \ldots \ldots 9.6$ & & 63.2 & 61.9 & 65.9 & 74.7 & & 76.2 & \\
\hline $\mathrm{Al}_{2} \mathrm{O}_{3} \ldots \ldots \ldots \ldots \ldots \ldots \ldots .2$ & & 19.2 & 20.4 & 18.0 & 14.0 & & 14.8 & \\
\hline $\mathrm{Fe}_{2} \mathrm{O}_{3} \ldots \ldots \ldots \ldots \ldots \ldots \ldots$ & & 5.9 & 6.5 & 6.9 & 4.2 & & 2.8 & \\
\hline $\mathrm{CaO} \ldots \ldots \ldots \ldots \ldots \ldots \ldots \ldots$ & & .16 & .15 & .12 & .11 & & .11 & \\
\hline $\mathrm{K}_{2} \mathrm{O} \ldots \ldots \ldots \ldots \ldots \ldots \ldots \ldots \ldots \ldots$ & & .25 & .23 & .24 & .26 & & .38 & \\
\hline $\mathrm{TiO}_{2} \ldots \ldots \ldots \ldots \ldots \ldots \ldots$ & & 1.15 & 1.17 & 1.18 & .87 & & .87 & \\
\hline $\mathrm{P}_{2} \mathrm{O}_{5} \ldots \ldots \ldots \ldots \ldots \ldots$ & & .10 & .10 & .08 & .09 & & .09 & \\
\hline MnO $\ldots \ldots \ldots \ldots \ldots \ldots \ldots \ldots, \quad .04$ & & .03 & .03 & .02 & .03 & & .03 & \\
\hline Total $^{1} \ldots \ldots \ldots \ldots \ldots \ldots \ldots 97.8$ & & 90.1 & 90.50 & 92.5 & 94.3 & & 95.4 & \\
\hline $\mathrm{Fe}_{2} \mathrm{O}_{3}+\mathrm{Al}_{2} \mathrm{O}_{3} / \mathrm{SiO}_{2} \ldots$ & & .397 & .435 & .38 & .244 & & .148 & \\
\hline 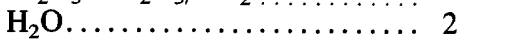 & & 10 & 10 & 9 & 6 & & 6 & \\
\hline
\end{tabular}

${ }^{1}$ Totals significantly less than 100 percent are due to high $\mathrm{H}_{2} \mathrm{O}$ contents of clay-rich horizons. $\mathrm{H}_{2} \mathrm{O}$ not included in analyses.

${ }^{2}$ Depths in centimeters are given in parentheses.

Table 13A. Textural analyses of horizons for unnumbered soil developed in Flint River terrace alluvium [Series not designated, Upson County, Ga. Grain sizes in millimeters; all other values in weight percent. VF, very fine; F, fine; M, medium; C, coarse; VC, very coarse]

\begin{tabular}{|c|c|c|c|c|c|c|c|c|c|c|c|}
\hline \multirow[b]{2}{*}{$\begin{array}{l}\text { Depth } \\
\text { (cm) }\end{array}$} & \multirow[b]{2}{*}{ Horizon } & \multicolumn{3}{|c|}{ Total } & \multicolumn{2}{|c|}{ Silt } & \multicolumn{5}{|c|}{ Sand } \\
\hline & & $\begin{array}{c}\text { Clay } \\
(<.002)\end{array}$ & $\begin{array}{c}\text { Silt } \\
(.002-.05)\end{array}$ & $\begin{array}{l}\text { Sand } \\
(.05-2)\end{array}$ & $\begin{array}{c}F \\
(.002-.02)\end{array}$ & $\begin{array}{c}\mathrm{C} \\
(.02-.05)\end{array}$ & $\begin{array}{c}\text { VF } \\
(.05-.10)\end{array}$ & $\begin{array}{c}\mathrm{F} \\
(.10-.25)\end{array}$ & $\begin{array}{c}M \\
(.25-.50)\end{array}$ & $\begin{array}{c}C \\
(.5-1)\end{array}$ & $\begin{array}{c}\text { VC } \\
(1-2)\end{array}$ \\
\hline $0-15 \ldots \ldots$ & Ap & 18.9 & 23.8 & 57.3 & 15.4 & 8.4 & 9.9 & 25.8 & 14.0 & 5.4 & 2.2 \\
\hline $15-25 \ldots \ldots$ & $\mathrm{AB}$ & 47.3 & 18.3 & 34.4 & 12.1 & 6.3 & 5.1 & 15.6 & 8.6 & 3.8 & 1.3 \\
\hline $25-51 \ldots \ldots$ & Bt1 & 49.0 & 18.4 & 32.6 & 13.1 & 5.3 & 4.9 & 14.5 & 8.1 & 3.7 & 1.4 \\
\hline $51-91 \ldots \ldots$ & Bt2 & 55.0 & 15.9 & 29.1 & 11.3 & 4.6 & 3.8 & 10.1 & 6.7 & 5.4 & 3.1 \\
\hline $91-127$. & Bt3 & 51.8 & 18.8 & 29.4 & 12.9 & 5.9 & 3.9 & 7.2 & 6.3 & 6.6 & 5.4 \\
\hline $127-152 \ldots$ & BC & 45.0 & 22.1 & 32.9 & 17.4 & 4.7 & 5.1 & 7.5 & 6.0 & 7.4 & 6.9 \\
\hline $152-178 \ldots$ & C1 & 43.0 & 27.2 & 29.8 & 21.6 & 5.6 & 7.0 & 10.8 & 4.8 & 4.3 & 2.9 \\
\hline $178-193 \ldots$ & $2 \mathrm{C} 2$ & 42.7 & 23.3 & 34.0 & 18.1 & 5.2 & 5.0 & 8.8 & 5.4 & 6.6 & 8.2 \\
\hline $193-213 \ldots$ & $2 \mathrm{C} 3$ & 41.0 & 28.3 & 30.7 & 19.9 & 8.4 & 9.0 & 8.2 & 5.5 & 4.9 & 3.1 \\
\hline $213-236 \ldots$ & $2 \mathrm{C} 4$ & 23.7 & 27.2 & 49.1 & 18.1 & 9.1 & 9.5 & 13.9 & 10.5 & 8.5 & 6.7 \\
\hline
\end{tabular}

Table 13B. Other analyses of horizons for unnumbered soil developed in Flint River terrace alluvium

[Units of measure for all values given in table 5]

\begin{tabular}{|c|c|c|c|c|c|}
\hline \multirow[b]{2}{*}{$\begin{array}{l}\text { Depth } \\
(\mathrm{cm})\end{array}$} & \multirow[b]{2}{*}{$\underset{C}{\text { Organic }}$} & \multirow[b]{2}{*}{$\begin{array}{l}\text { Ratio clay } \\
\text { (15 bar) }\end{array}$} & \multirow[b]{2}{*}{$\begin{array}{l}\text { Water content } \\
\qquad(15 \text { bar })^{1}\end{array}$} & \multicolumn{2}{|c|}{$\mathrm{pH}$} \\
\hline & & & & $\begin{array}{l}\mathrm{CaCl}_{2} \\
(1: 2)\end{array}$ & $\begin{array}{l}\mathrm{H}_{2} \mathrm{O} \\
(1: 1)\end{array}$ \\
\hline $0-15$. & 1.90 & 0.48 & 9.1 & 5.3 & 6.1 \\
\hline $15-25 \ldots \ldots \ldots \ldots$ & .64 & .35 & 16.4 & 4.5 & 5.1 \\
\hline $25-51 \ldots \ldots \ldots \ldots$ & .25 & .35 & 17.1 & 4.5 & 5.1 \\
\hline $51-91 \ldots \ldots \ldots \ldots$ & .14 & .38 & 21.0 & 4.5 & 5.1 \\
\hline $91-127 \ldots \ldots \ldots \ldots$ & .05 & .44 & 23.0 & 4.3 & 5.0 \\
\hline $127-152 \ldots \ldots \ldots \ldots$ & .03 & .48 & 21.6 & 4.3 & 5.0 \\
\hline $152-178 \ldots \ldots \ldots$ & .03 & .54 & 23.2 & 4.3 & 5.0 \\
\hline $178-193 \ldots \ldots \ldots$ & .04 & .53 & 22.8 & 4.3 & 4.9 \\
\hline $193-213 \ldots \ldots \ldots$ & .01 & .57 & 23.3 & 4.3 & 4.9 \\
\hline $213-236 \ldots \ldots \ldots$ & .05 & .92 & 21.9 & 4.5 & 5.4 \\
\hline
\end{tabular}

${ }^{1}$ Water content at 15 -bar pressure. 
Table 14. Sand $(>50 \mu \mathrm{m})$ mineralogy of Pine Mountain soils

[All values in percent, based on a minimum count of 300 grains. -1 , less than 1 percent; 0 , not observed]

\begin{tabular}{|c|c|c|c|c|c|}
\hline \multirow{2}{*}{$\begin{array}{c}\text { Depth } \\
(\mathrm{cm})\end{array}$} & \multirow[b]{2}{*}{ Horizon } & \multicolumn{4}{|c|}{ Mineral } \\
\hline & & Quartz & Muscovite & Biotite & K-feldspar \\
\hline \multicolumn{6}{|c|}{ Piedmont soil (S84GA-199_001) } \\
\hline $0-15$. & A & 95 & -1 & -1 & 3 \\
\hline $15-79$. & $\mathrm{Bt}$ & 73 & 8 & 5 & 4 \\
\hline $79-154$. & $\mathrm{BC}$ & 57 & 2 & 29 & 1 \\
\hline $216-254$. & $\mathrm{C} 2$ & 25 & 2 & 70 & 1 \\
\hline $254-304 \ldots \ldots$ & C3 & 13 & 1 & 41 & 43 \\
\hline \multicolumn{6}{|c|}{ Mountain soil dike (S84GA-231-001) } \\
\hline $20-38$ & $\mathrm{E}$ & 97 & 2 & 0 & 0 \\
\hline$\ldots \ldots \ldots \ldots$ & $2 \mathrm{Bt} 2$ & 66 & 31 & 0 & 0 \\
\hline $114-220 \ldots \ldots \ldots \ldots \ldots$ & $2 \mathrm{Bt} 4$ & 49 & 48 & 0 & -1 \\
\hline
\end{tabular}

Mountain soil (S84GA-231-003)

\begin{tabular}{|c|c|c|c|c|c|}
\hline $33-53$ & $\mathrm{AB}$ & 96 & 3 & 1 & -1 \\
\hline 53-71. & $\mathrm{B} / \mathrm{C}$ & 94 & 4 & -1 & 0 \\
\hline 87-114. & $\mathrm{C} 2$ & 89 & 10 & 0 & 0 \\
\hline $138-150$ & $\mathrm{C} 4$ & 46 & 56 & 1 & 0 \\
\hline $150-178$ & C5 & 12 & 87 & 0 & 0 \\
\hline $179-191$ & $\mathrm{C} 6$ & 92 & 8 & 0 & 0 \\
\hline $191-204$ & $\mathrm{C} 7$ & 12 & 88 & 0 & 0 \\
\hline $204-221$ & $\mathrm{C} 8$ & 47 & 52 & 0 & 0 \\
\hline $221-230$ & C9 & 15 & 82 & 0 & 0 \\
\hline
\end{tabular}

Mountain soil (S84GA-231-004)

\begin{tabular}{|c|c|c|c|c|c|}
\hline $13-38$ & $\mathrm{E}$ & 99 & 0 & -1 & 0 \\
\hline 61-91. & $\mathrm{Bt} 1$ & 96 & 1 & 1 & 0 \\
\hline $145-168$ & $\mathrm{~B} / \mathrm{C}$ & 64 & 33 & 2 & 0 \\
\hline $168-183$ & $\mathrm{Cr}$ & 83 & 14 & 1 & 0 \\
\hline
\end{tabular}

Landslide/mountain (S84GA-231-002)

\begin{tabular}{|c|c|c|c|c|c|}
\hline $13-22$ & $\mathrm{AB}$ & 98 & -1 & 0 & 1 \\
\hline $44-74 \ldots$ & $\mathrm{Bt1}$ & 99 & 0 & -1 & 0 \\
\hline $170-205$ & $\mathrm{~B} / \mathrm{C}$ & 90 & 6 & 0 & 0 \\
\hline $300-360$ & $2 \mathrm{C}$ & 17 & 76 & -1 & -1 \\
\hline \multicolumn{6}{|c|}{ Fan soil (S84GA-293-001) } \\
\hline $69-97$ & Bt1 & 99 & 0 & 0 & 0 \\
\hline $175-205$ & $\mathrm{~B} \times 2$ & 87 & 0 & 0 & -1 \\
\hline
\end{tabular}

Fan soil (S84GA-199-002)

\begin{tabular}{lllllr}
\hline $0-15 \ldots \ldots \ldots \ldots \ldots \ldots \ldots$ & A & 99 & 0 & 1 & -1 \\
$44-98 \ldots \ldots \ldots \ldots \ldots \ldots$ & Bt 2 & 99 & 0 & 1 & -1 \\
$130-164 \ldots \ldots \ldots \ldots \ldots$ & $2 \mathrm{Bx} 2$ & 95 & 1 & 0 & 0 \\
$235-250 \ldots \ldots \ldots \ldots \ldots$ & $2 \mathrm{~B} \times 5$ & 91 & 1 & 1 & 0 \\
\hline
\end{tabular}




\section{Appendix}

The following articles, reprinted from internal publications of the U.S. Geological Survey, have been included because they may be of historical interest to the reader. 


\section{FDR vs USGS: or The Cold Facts About Warm Springs \\ [Reprinted from the Director's Newsletter, v. 1, no. 3, 1979, p. 14, 15$]$}

In the summer of 1921, Franklin D. Roosevelt had an attack of polio that left him crippled. The former Assistant Secretary of the Navy, who had been the Democratic nominee for Vice President in 1920, had to give up his plans to run for Governor of New York in 1922. Instead he fought valiantly to recuperate. Swimming in warm water seemed especially effective in helping him regain some of the strength he had lost to the disease.

His search for rehabilitation led Roosevelt to Warm Springs, Ga., once a fashionable summer resort. When he first went there in 1924, not long after he had nominated Al Smith for President at the Democratic convention, Roosevelt found the resort had run down. But he found also that the naturally warm water, issuing from springs and led into both indoor and outdoor pools, seemed to help his damaged legs.

Two years after his first visit, Roosevelt bought the Warm Springs resort, determined to bring back its former grandeur. But when in 1927 he realized that he could not make Warm Springs into another Pinehurst, he turned it instead into a health spa run by the newly formed Georgia Warm Springs Foundation. Three physicians and therapists treated the victims of polio in the warm waters of the springs.

Roosevelt sought endorsements of the benefits of Warm Springs' waters. Late in 1927 he wrote the Director of the Geological Survey, asking him to undertake "a careful survey of all the mineral springs in this locality" to aid the Foundation in putting them to medical use. With the scientific skepticism for which the Survey is famous, the Acting Director replied that mineral springs were valuable chiefly for their location. Since people came to them for treatment, resorts could be built up around them, but their water was not really different from that which flowed through city water pipes.

Roosevelt was outraged. Like anyone who has been strong and healthy until struck down, he dreamed of regaining full use of his legs, and he believed that swimming at Warm Springs was helping him do it. The Survey's coldly scientific response to his request for evidence to support his belief would not help him build a hospital to treat those who had suffered as he had. In spite of Roosevelt's repeated requests, the Survey refused to make the study. Late in 1928 Roosevelt turned away from his efforts for Warm Springs. He ran for Governor of New York and was elected. After two terms in the Governor's mansion in Albany, N.Y., he went in 1933 to the White House in Washington as the 32nd President of the United States.

Like any other agency of the Executive Branch of the United States Government, the Survey will do for the President what it may or may not do for a private citizen.
When Roosevelt renewed through Harold Ickes, his Secretary of the Interior, the request for a geological survey of the Warm Springs area, the Geological Survey obliged. Director W. C. Mendenhall set up a cooperative project with the State of Georgia. D. Foster Hewett of the USGS and G. W. Crickmay of the Georgia Geological Survey began in the fall of 1933 to study the Pine Mountain area around Warm Springs. J. O. Kilmartin made a new topographic map, Crickmay did the areal mapping, and Hewett had general oversight of the project, paying particular attention to the natural springs. He relied heavily on O. E. Meinzer of the Water Resources Branch (now Division) and his colleagues L. K. Wenzel and W. L. Lamar. The district engineers from the office at Montgomery, Ala., also helped out. In Hewett's words, "the program, including geologic, physical, and chemical measurements of the water of the region was the most ambitious on a warm spring area ever undertaken in the United States."

Crickmay and Hewett began work in October 1933, so they were at Warm Springs when President Roosevelt made his annual Thanksgiving visit. He carved a large turkey for the young patients and the Foundation's trustees, and after dinner he introduced the guests, including the two geologists. "There has never been any scientific survey of this Pine Mountain region," Roosevelt began their introduction. "I tried a number of years ago to get the U.S. Government interested in a geological survey of this mountain of ours, but I was told by the Government that then existed in Washington, that there was nothing in the water anyway." The audience laughed. "But in the past few months," the President went on, "I have been able, somehow, to persuade Washington that there is something in the water, and so the Geological Survey in Washington is cooperating with the State of Georgia, and we are starting a survey of what lies under Pine Mountain." More laughter followed this account of his persuasiveness. As if to inspect the research, Secretary Ickes visited the President the weekend after Thanksgiving.

The geological investigation of Warm Springs by Hewett and Crickmay lasted about three years. They published their results in 1937 as Water-Supply Paper 819 entitled The Warm Springs of Georgia, Their Geologic Relations and Origin, A Summary Report. By then President Roosevelt could no longer find time to go to Warm Springs for Thanksgiving every year as he had in his first term. And what the geologists reported could not have been to his liking.

For the result of the careful scientific study was to confirm the Geological Survey's initial skepticism. "The water which issued from Warm Springs at a temperature of $88^{\circ}$ was that which had fallen as rain on Pine Mountain within several square miles south of the spring.... The water was extremely simple chemically and similar to that which issued from springs elsewhere in the region." Far from being unusual, the water from Warm Springs "was simply 
rain water that had fallen on Pine Mountain, descended along a bed of quartzite in the earth, and ascended along the fault that marked the north edge of Pine Mountain."

Thus Foster Hewett confirmed what the Acting Director had told Roosevelt in 1927; there was nothing special about the water from Warm Springs.

Roosevelt's Georgia Warm Springs Foundation continued to offer treatment to the victims of polio. In 1938, the year after the Survey's report, Roosevelt established the National Foundation for Infantile Paralysis (the name then for polio) which sponsored research to find a cure. This research paid off in the 1950's with the development of vaccines, and the Georgia Warm Springs Foundation stopped treating polio victims in its spring-fed pools. As a source for the treatment of polio, rational medicine had replaced the faith healing associated with natural springs. What remains at Warm Springs, Ga., is a state rehabilitation hospital for all the crippling diseases. And the Little White House is a memorial to President Roosevelt, for whom no treatment ever restored the use of his legs.

\section{An Historical Footnote \\ Warm Springs, Georgia, 1933-1936 \\ By D. Foster Hewett}

[Reprinted from The Cross Section, v. 10, no. 6, June 1979, p. 9-15]

On November 8, 1927, Franklin Delano Roosevelt, then a private citizen, wrote to the Director of the U.S. Geological Survey a letter expressing the wish that the Geological Survey would undertake a detailed study of the Warm Springs area in Georgia. The letter is interesting:

"As you probably know, I became interested in the place two years ago, and since then have organized the Georgia Warm Springs Foundation, a medical corporation under the laws of the State of New York without profit, which Foundation is engaged in developing a therapeutic treatment here for infantile paralysis and kindred diseases.

As our work goes on, we see more and more need for a careful survey of all the mineral springs in this locality-The immediate thing before the Foundation undertakes the development or detailed explorations of any given spot, is for us to have a general geologic survey on which we can base a more detailed examination of springs-We have had visits from two distinguished balneologists for Germany (Haertl and Baudish) who tell us that the mineral springs of this general locality are very remarkable and compare most favorably with the better known Bohemian; German, and French mineral springs. In fact, the general geological formation seems to me, as a lay observer, to resemble in many particulars the Taunus region in Germany, which includes Nauheim, Homberg, and Weisbaden.

It is a matter of great medical importance that the mineral springs of this country be developed for our own use, and the Georgia Warm Springs Foundation hopes to be able to go into the general subject as well as the development of our immediate work for infantile paralysis, etc."
The Director of the Survey, G. Otis Smith, was away from Washington at the time and the reply, dated November 22 , was signed by the Acting Director. In substance, this letter declined the invitation to make a detailed study of the area, but unfortunately it included the following paragraph:

"The men in the Geological Survey who have given the most attention to the question of mineral springs and their use are generally of the opinion that practically the whole value of mineral springs is as an excuse for the location at a particular point of a resort or center for the use of water in the treatment of disease."

Mr. Roosevelt acknowledged this letter December 15 , requesting any information at hand concerning composition of waters elsewhere in the country that resembled those at Warm Springs, Georgia. It contained the following paragraph: "I think possibly that there may be a misconception in regard to the use of the Georgia Warm Springs water. The present rather careful scientific studies are based on the use of water to bathe and swim in and not for drinking purposes."

This letter was acknowledged and the desired information given. However, on December 21, Mr. Roosevelt wrote again, obviously revealing that he was deeply offended by statements in the first letter. He wrote:

"Quite frankly, I was a good deal horrified by Mr. Sears' letter, and my surprise at the attitude of the Geological Survey was shared by Mr. George Foster Peabody and several doctors who are working with me, including some of the people of the Rockefeller Institute. Of course, the truth of the matter is that we people in the United States are 25 years behind Europe in the study and knowledge of the pathologic effect of mineral water on the human system and of the methods in the use of mineral water for the treatments of various forms of human illnesses.... You may therefore imagine that I was somewhat surprised by being practically told by Mr. Sears that this Foundation was trying to use the Geological Survey as an excuse for locating the work of the Foundation at a Georgia resort and that very little scientific evidence could be produced to show that they could not carry on the treatment just as well in New York, Washington, or Chicago.

I know, my dear Dr. Smith, that you will see the humor in this situation and all I can ask you is to take up the matter afresh, for I know of your understanding of these matters and I hope that you will give some real study to the possibility of the Georgia Warm Springs Foundation. I can only tell you that the medical experts are finding some very interesting results at Warm Springs from the bathing in natural warm water."

The reply of the Director, January 7, 1928 was conciliatory, but it refused the cooperation of the Survey. This brought a letter from Mr. Roosevelt, dated January 11, which reveals that he was confident that therapeutic use of water in the United States was lagging far behind that in Europe, and he greatly regretted that the Survey would not assist him: 
"I am sorry as a layman to take issue with you in regard to the proper method of possible development of any given area of the earth's surface which contains mineral springs of a variety of mineral contents - I am afraid that you have wholly missed the point of the request of the Georgia Warm Springs Foundation for a geological study.

We do not need any such study to determine the value of the water which in many places now flows naturally from Pine Mountain. Dr. Baudisch, Dr. Haertl, various doctors of the Rockefeller Institute, and several well known geologists have advised the Foundation that before large amounts of money are asked for as gifts by the public for the erection of buildings, etc. for the care of patients, it is necessary to find out more about the existing springs and possibly other springs before they come to the surface. For instance, by boring and tapping the water well below the surface, greater heat can be obtained. Also by boring, the chemical properties of the same spring may vary, as has been proved at Saratoga. By a careful preliminary geologic study, the Foundation would know where to bore and what it might find in the way of water at different locations and at different depths.

I cannot help expressing my disappointment that the Geological Survey takes the antiquated view that the city water supplies of New York, Chicago, or Washington would, if given similar conditions, produce the same results as scientific tests of natural mineral springs tapped far below the ground at different temperatures and with different mineral contents. We shall, of course, proceed with the cooperation of the State of Georgia and with such gifts as the Foundation may receive. I am only sorry not to have the cooperation of the United States Government in a study which promises greater things for many parts of the country which contain mineral springs."

Several letters passed before August 1933 between Dr. Mendenhall, then Director of the Geological Survey, and the State Geologist, S.W. McCallie and George Foster Peabody, an intimate friend of Mr. Roosevelt's. On August 19, 1933 the President of the United States (Mr. Roosevelt) sent the following memorandum to Secretary Ickes:

"Would you be good enough to have Dr. Mendenhall look up all the old correspondence on the subject of a geological survey of Pine Mountain, Georgia. Perhaps Dr. Mendenhall would talk with me about it when I get back in September. Sgd/F.D.R."

On August 24, Secretary Ickes wrote the President, as follows:

"Mr. Mendenhall, Director of the Geological Survey, has reviewed the old correspondence about a geological survey of the Pine Mountain region and is now in communication with Dr. McCallie, State Geologist of Georgia, about the problem. Between them they will work out a method, perhaps cooperative, by which the desired study can be made."

As a result of this correspondence, plans were made through September for a cooperative study of the Warm Springs area, with particular reference to the warm springs.

G.W. Crickmay was selected to represent the State Survey, primarily to do the areal mapping; I was selected to pay particular attention to the warm springs and to oversee the project. Through discussion with O.E. Meinzer, of the Water Resources Branch, general plans were made for a comprehensive study of the Pine Mountain region. It was known that there were other warm springs along the north slope of Pine Mountain within a distance of 40 miles, and the program of investigation that was planned included detailed geologic mapping of about 40 square miles near the spring, accurate records of rainfall, the discharge of all the streams from the 40 square miles, and discharge and temperature of the principle [sic] springs-the warm springs, and a large cold spring a mile away.

Meinzer drew in for aid and consultation the talent of the Water Resources Branch, particularly, L.K. Wenzel and W.L. Lamar. There were also drawn into the project the engineers of the Water Resources Branch at Montgomery, Alabama: C.E. McCarshin, DeLoss H. Barber. It was arranged that a new topographic map on the scale of $1: 48,000$ would be made, and this was done by J.O. Kilmartin. It is fair to say that the program, including geologic, physical, and chemical measurements of the water of the region was the most ambitious on a warm spring area ever undertaken in the United States. It was clear that the authorities at Warm Springs were anxious to not only obtain more warm water and to conserve its supply, but, if possible, to get, possibly by drilling, warmer water.

The Georgia Warm Springs Foundation was founded in 1925, as a non-profit organization to develop the treatment of poliomyelitis and paralysis resulting from it. Briefly, the incidents preceding were as follows: $\mathrm{Mr}$. George Foster Peabody, in 1933 a retired banker and philanthropist, was born in Columbus, Georgia, and at the end of the Civil War, with his brothers was taken by his mother to New York. His life is a fascinating story of industry and philanthropy. He acquired great wealth, which in his maturity, he proceeded to dispense in philanthropy, particularly the education of negroes in the south.

As a boy he had known of the existence of Warm Springs, which was an old-fashioned health resort as early as 1840 . When Mr. Roosevelt was stricken with infantile paralysis, Mr. Peabody recalled the warm springs of Georgia, and suggested that he might be benefited by bathing in the waters. A visit by Mr. Roosevelt proved this to be the case with the result that $\mathrm{Mr}$. Peabody purchased for $\$ 45,000,175$ acres which included the grounds around the springs and a hotel which he proceeded to deed to $\mathrm{Mr}$. Roosevelt. With a few improvements of the pools and the addition of sundry apparatus used in the therapy, the plant stood in October 1933 just about as it was when $\mathrm{Mr}$. Peabody bought it in 1925. The hotel, an old 3-story frame structure, was a firetrap, and it is miraculous that no catastrophe ever came. In 1933, construction was begun on the first new building - Georgia Hall - which included administration quarters and dining facilities. 
When I arrived in Warm Springs October 17, 1933, we found a room with Mrs. J. Mathis and obtained our meals from Mrs. Wm. Reid; both of their houses were on the north fringe of the town of Warm Springs. I soon met the manager of the Foundation, Arthur Carpenter, and his staff, but particularly dealt with his assistant, Ralph Sherrill, who proved to be most helpful and accommodating. When I explained the program of work to Mr. Carpenter, himself a victim of infantile paralysis, it was quite clear that he and others of the Foundation, including Miss Plastridge, the head nurse, not only had great confidence in the peculiar healing properties of the water, but were rather reluctant that any routine at the Foundation should be disturbed by any process of inquiry that we might set up. We soon faced this problem when I wished to have all the pools drained in order that I might examine the inner recesses from which the water issued from the earth.

The program of work continued through October into November, and we were interested when it was announced that the trustees of the Foundation would meet about Thanksgiving and that a dinner would be held at which the President would be present. As Mr. Peabody arrived in Warm Springs soon after I did and we had come to know him rather well, he arranged to have Crickmay and me, with our wives, invited to the Thanksgiving dinner.

At the dinner, there were present not only the President and the trustees, but other distinguished local guests, as well as all the patients of the institution, the nurses, and other assistants; the total of about 300 .

It was a very interesting evening. The President, according to his habit, was seated in the midst of a group of young patients. He took great delight in carving a large turkey. When the dinner was over Mr. Roosevelt rose to discuss the plans for the Foundation, and then introduced the many guests that were present. Imagine my surprise when late in the ceremonies he said, "About six years ago I attempted to get the U.S. Geological Survey to make a study of Warm Springs to aid our plans for the Foundation, and was told that there was nothing in this water business. I am pleased to say that since the last election, the U.S. Geological Survey has found that there is something in water after all. I take pleasure in introducing Mr. Hewett of the Federal Survey and Mr. Crickmay of the State Survey, who are here to make a study of the warm springs."

Among the guests over Thanksgiving was Dr. Paul Haertl, Managing Director of Bad-Kissingen, Germany. I am not sure, but I think Dr. Haertl must have been a Prussian because he was the Perfect Type! He was more than 6 feet tall, weighed about 200 pounds $(90.9 \mathrm{~kg}$.), and had a certain arrogance in demeanor that seemed to me typical. He had been brought to Saratoga some years before by the Saratoga Springs Commission to advise it concerning the conservation and development of its water.

Saratoga Springs had for many years been owned privately by certain persons who in their zeal to exploit the enormous quantities of carbon dioxide gas given off were drawing on these sources so freely that many springs in the area were failing. Soon thereafter, the springs were acquired by the State of New York and a program of orderly development and conservation began. Much of this was due to the vision and efforts of Mr. Peabody, who was Chairman of the Saratoga Springs Commission.

As we were planning to make the most comprehensive study of the warm springs that had been undertaken, I thought it would be fitting to discuss with Dr. Haertl the general program of investigation. He seemed pleased and interested, and I told him all of the work that was planned: the geologic study, the measurements of discharges of streams, chemical characteristics and temperature of the water, etc. After we had talked at great length, Dr. Haertl asked, "Are you studying the gas that comes from the water?" I replied that we were, and that I had collected samples of the gas for chemical analysis. He said, "Have you examined the shape of the bubbles?" Somewhat aghast, I said that we had not. He said, "Oh, you must examine the bubbles; some bubbles are round, but others are square."

I could hardly believe my ears, so I pressed the subject. "Do I understand that you know places in Germany where the bubbles issuing from water are square?" He replied, "Oh yes, Mr. Hewett. The bubbles of gas at Bad-Kissingen are square. You see, Mr. Hewett, when you put your arm in water that contains gas, bubbles appear on the flesh. Now, if these bubbles are round they produce no effect, but if they are square they have the effect of stimulating the nerves of the skin. It is extremely important that you determine whether these bubbles are round or square."

It took me some time to realize that Dr. Haertl was serious. To make a long story of my relations with Dr. Haertl for two weeks very short, I concluded that he was a typical P.T. Barnum in this hot springs business. He knew something of modern scientific lore, but whether deliberately or by some self-deception, he certainly affirmed a lot of foolishness. I could scarcely believe that a man of this type was held in high esteem by Mr. Peabody, as Dr. Haertl was a consultant to the Saratoga Springs Commission, and seemed to have a somewhat similar relation to the Warm Springs Foundation. I concluded that I must be very circumspect in dealing with him.

I thought it appropriate to show him the inner recess in which the warm spring issued. To do this, it was necessary to descend a concrete chamber in our bathing suits and crawl through a hole in the retaining wall, scarcely 2 feet in diameter, beyond which there was a chamber about 5 feet square and 3 feet high on the side of which warm water issued from an open fissure. Of course, it was dark and we had to use flashlights to guide us. Dr. Haertl was in an awkward position. He was terrified at the thought of entering the chamber, but since he had posed as an authority on 
warm springs he could not withdraw. The experience for 20 minutes in that inner chamber kept him in a high state of nervousness. I was quite sure that he had never gone through such an experience before. I should add that later when we did examine the gas, the bubbles were round.

As it was planned to continue some of the measurements for two years, I returned to Warm Springs each quarter and devoted several weeks on each visit to checking the state of the instruments making the measurements. By the spring of 1936 our work had been concluded to the point where we knew much about the water and its source, and were preparing to make some recommendations to the Foundation. Through three separate approaches to the problem, our work proved that the water which issued from Warm Springs at a temperature of $88^{\circ}$ was that which had fallen as rain on Pine Mountain within several square miles south of the spring. The daily measurements of the discharge of warm springs made for two years, reflected the periods of rainfall and drought, accurately. From another angle, through measurements of rainfall and the discharge of streams we found what part of the total rainfall was discharged by the streams south of Pine Mountain and the discharge per acre of the ten streams.

By contrast, we found that the streams discharging from the north side of Pine Mountain were deficient by just the amount of water that issued at the warm and cold springs. The water was extremely simple chemically and similar to that which issued from springs elsewhere in the region. Through what sources I cannot be sure, the local doctors, as well as Dr. Baddisch, an assistant of Dr. Haertl's, had the impression that ultra-violet rays penetrated the Warm Springs water more readily than any other water.

It was also freely stated that Warm Springs water was "more buoyant than other water." Curiously, none of those who used these terms seemed to realize that buoyancy is a relation between the specific gravity of two substances and not a property. In order to be fortified concerning the specific gravity of the water, I personally collected and brought to Washington a sample of the water-the specific gravity of which was determined under highly accurate control at the Bureau of Standards. It was found that the specific gravity was exactly what it should be with the ingredients dissolved in it.
It was a great disappointment to Mr. Peabody and his daughter, Mrs. Marjorie Waite, as well as others at the Foundation, when I told them in the spring of 1936 that there seemed to be nothing extraordinary about this water, that it was simply rain water that had fallen on Pine Mountain, descended along a bed of quartzite in the earth, and ascended along the fault that marked the north edge of Pine Mountain. I still recall Mrs. Waite's remark, "Oh, I am so sorry. We had hoped that the unusual properties of this water were due to the fact that it was water appearing at the surface of the earth for the first time!"

Even though the results of our investigation of Warm Springs found that the water was ordinary rain water without exceptional physical or chemical properties, I hesitate to view with scorn the widely-held belief that the water possessed miraculous properties. There can be nothing but admiration for the work the Foundation has done to bring back to normal living, hundreds of young children who would otherwise have gone through life with deformed bodies. The belief in the miraculous beneficial properties of Warm Springs water probably contributed to a widely prevailing spirit of hope and optimism that all of the patients seemed to share.

During the three years that I visited Warm Springs, I saw children arrive at the institution in various stages of frightful deformity, gradually recover a large part, if not all, the use of their limbs It is a tribute to the spirit and talent of all those who aid the institution that such miracles can be accomplished. I am almost sorry that much of this cannot be attributed to the properties of the water that issues at Warm Springs.

Perhaps in retrospect I should add that as I understand it, there are many institutions in the country now where victims of infantile paralysis are treated and that use only local water from wells, streams, etc., which has been heated to the temperature which facilitates the treatments.

The letter written by the Director of the Survey to Mr. Roosevelt in November 1927 contained indiscretions, particularly the reference to the use of springs by real estate schemes, but most that was said in the letter seems now to have been proven absolutely correct, even though $\mathrm{Mr}$. Roosevelt was outraged when he read it.

When the Water Supply report (WSP 819) was printed in 1937 , a specially bound copy was sent to the President. Its receipt was never acknowledged! 


\section{AVAILABILITY OF BOOKS AND MAPS OF THE U.S. GEOLOGICAL SURVEY}

Instructions on ordering publications of the U.S. Geological Survey, along with prices of the last offerings, are given in the current-year issues of the monthly catalog "New Publications of the U.S. Geological Survey." Prices of available U.S. Geological Survey publications released prior to the current year are listed in the most recent annual "Price and Availability List." Publications that may be listed in various U.S. Geological Survey catalogs (see back inside cover) but not listed in the most recent annual "Price and Availability List" may be no longer available.

Reports released through the NTIS may be obtained by writing to the National Technical Information Service, U.S. Department of Commerce, Springfield, VA 22161; please include NTIS report number with inquiry.

Order U.S. Geological Survey publications by mail or over the counter from the offices given below.

\section{BY MAIL}

\section{Books}

Professional Papers, Bulletins, Water-Supply Papers, Techniques of Water-Resources Investigations, Circulars, publications of general interest (such as leaflets, pamphlets, booklets), single copies of Earthquakes \& Volcanoes, Preliminary Determination of Epicenters, and some miscellaneous reports, including some of the foregoing series that have gone out of print at the Superintendent of Documents, are obtainable by mail from

\section{U.S. Geological Survey, Information Services \\ Box 25286, Federal Center, Denver, CO 80225}

Subscriptions to periodicals (Earthquakes \& Volcanoes and Preliminary Determination of Epicenters) can be obtained ONLY from the

\section{Superintendent of Documents Government Printing Office \\ Washington, D.C. 20402}

(Check or money order must be payable to Superintendent of Documents.)

\section{Maps}

For maps, address mail orders to

U.S. Geological Survey, Information Services

Box 25286, Federal Center, Denver, CO 80225

Residents of Alaska may order maps from

\author{
U.S. Geological Survey, Earth Science Information Center \\ 101 Twelfth Ave. - Box 12 \\ Fairbanks, AK 99701
}

\section{OVER THE COUNTER}

\section{Books and Maps}

Books and maps of the U.S. Geological Survey are available over the counter at the following U.S. Geological Survey offices, all of which are authorized agents of the Superintendent of Documents:

- ANCHORAGE, Alaska-Rm. 101, 4230 University Dr.

- LAKEWOOD, Colorado-Federal Center, Bldg. 810

- MENLO PARK, California-Bldg. 3, Rm. 3128, 345 Middlefield Rd.

- RESTON, Virginia-USGS National Center, Rm. 1C402, 12201 Sunrise Valley Dr.

- SALT LAKE CITY, Utah-Federal Bldg., Rm. 8105, 125 South State St.

- SPOKANE, Washington-U.S. Post Office Bldg., Rm. 135, West 904 Riverside Ave.

- WASHINGTON, D.C.-Main Interior Bldg., Rm. 2650, 18th and C Sts., NW.

\section{Maps Only}

Maps may be purchased over the counter at the following U.S. Geological Survey offices:

- FAIRBANKS, Alaska-New Federal Bldg., 101 Twelfth Ave.

- ROLLA, Missouri-1400 Independence Rd.

- STENNIS SPACE CENTER, Mississippi-Bldg. 3101 


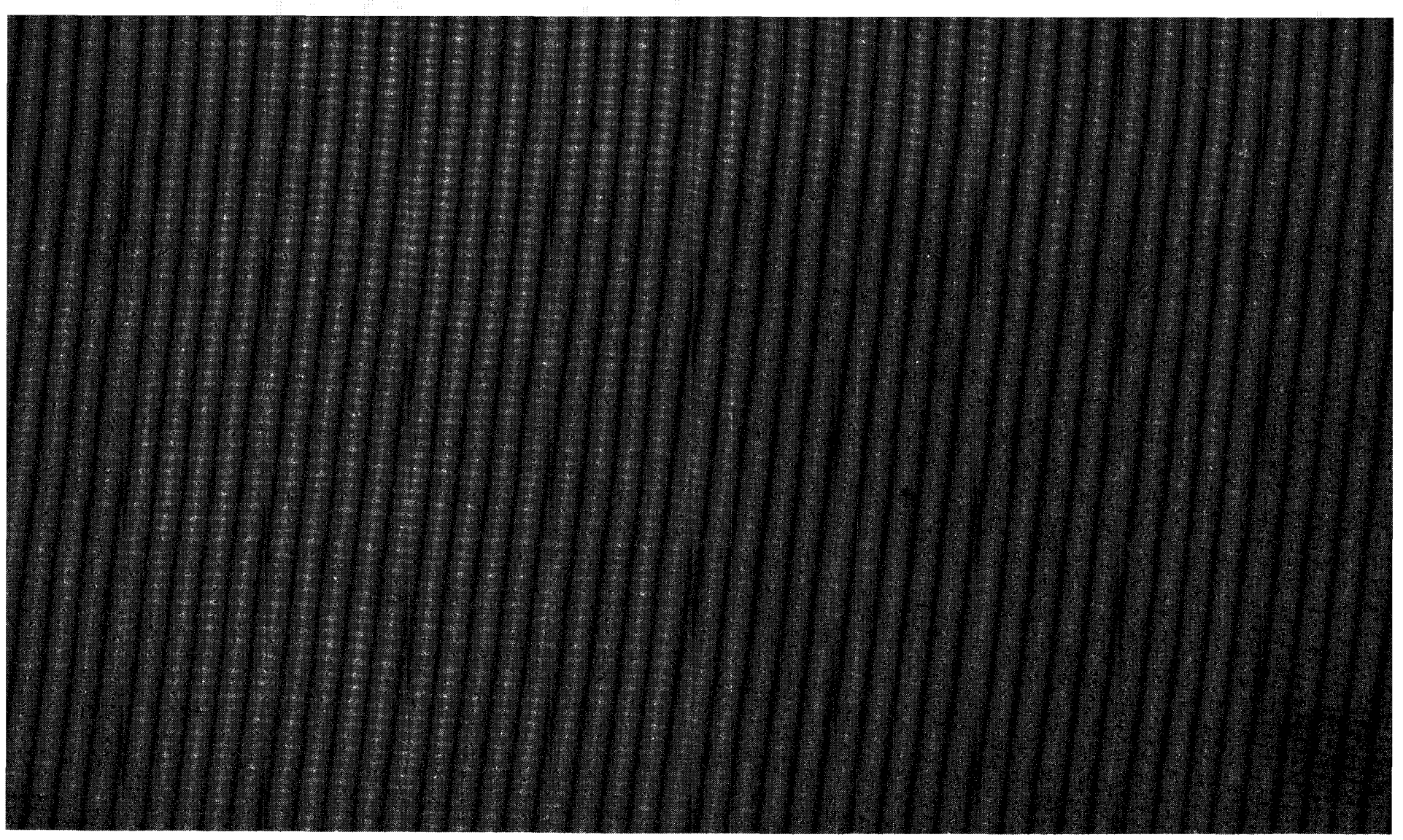

